Historic, Archive Document

Do not assume content reflects current scientific knowledge, policies, or practices. 


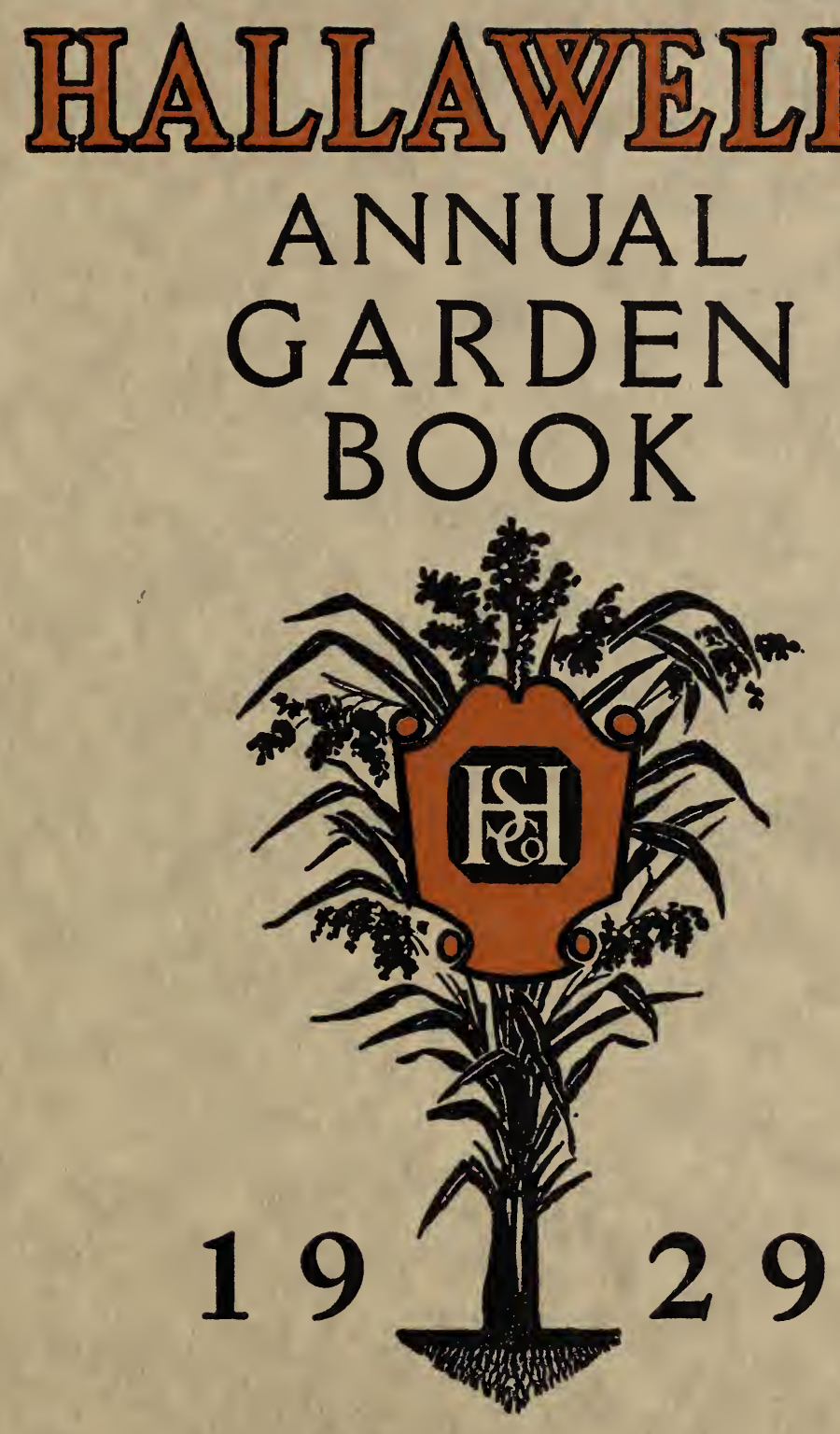


\section{Hallawell Seed Company}

STORE: 256-258 MARKET STREET, SAN FRANCISCO, CALIFORNIA

Warehouse: 30 Davis Street Store Phone Davenport 9587-8
Nursery : Quintara St. and 23d Ave., Sunset District Nursery Phone Montrose 7043

\section{GENERAL DIRECTIONS TO CUSTOMERS}

WE PREPAY CHARGES anywhere within the fourth parcel post zone on all vegetable, flower, field and grass seeds in packets, ounces, 1-pound and 10-pound lots. In quantities of twenty-five pounds and over, special prices will be made where not already listed, which do not include free delivery. Fifty-pound lots of seed are sold at the 100-pound lot rates. NURSERY STOCK, bulbs, fertilizers, insecticides and tools are not prepaid except where specially stated.

Please give names of express and freight offices where they differ from postoffice.

NON-WARRANTY-NOTE-We exercise great care in the selection of our stock but as there are so many contingencies to be encountered in growing plants from seed and in setting out plants that are dependent on weather and other conditions over which we have no control, that success in planting is not altogether dependent on the seed or plant. It being an established precedent of the Seed and Nursery Trade, we give no warranty, expressed or implied, as to description, quality, productiveness or any other matter of any seeds, bulbs, plants or trees we send out and we will not be responsible in any way for the crop. If the purchaser does not accept these terms the goods are to be returned at once. HALLAWELL SEED CO.

\section{SEASONS TO PLANT IN CENTRAL CALIFORNIA}

\begin{tabular}{|c|c|c|c|c|c|c|c|}
\hline अ2 & Wh & n & & (iul & Qua & 88 & the \\
\hline 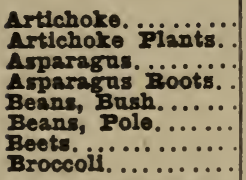 & 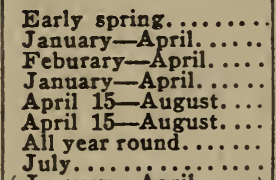 & $\begin{array}{l}\text { Second season. } \\
\text { Next season... } \\
\text { Third spring. } \\
\text { Next spring... } \\
45 \text { to } 65 \text { days. } \\
65 \text { to } 75 \text { days. } \\
65 \text { to } 75 \text { days. } \\
150 \text { to } 200 \text { days. }\end{array}$ & $\begin{array}{r}1 \text { inch....... } \\
1 \text { inch......... } \\
3 \text { inches.... } \\
1 \text { to } 2 \text { inches. } \\
1 \text { to } 2 \text { inches. } \\
1 \text { inch....... } \\
1 / 2 \text { inch...... }\end{array}$ & $\begin{array}{l}50 \text { feet. } \ldots \ldots \ldots . \\
\text { i ib. to } 100 \text { feet. } \\
1 \text { lib. to } 100 \text { hills } \\
50 \text { feet. } \ldots . . . . . \\
1,000 \text { plants.... }\end{array}$ & 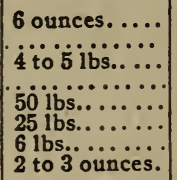 & 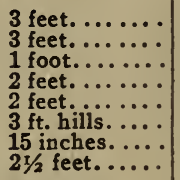 & $\begin{array}{l}2 \text { feet } \\
2 \text { feet } \\
3 \text { inches } \\
11 / 2 \text { feet } \\
3 \text { inches } \\
3 \text { ft. hills } \\
3 \text { to } 6 \text { inches } \\
11 / 2 \text { feet }\end{array}$ \\
\hline Bengele Snronts & ( January-April..... & 150 days...... & $1 / 2$ inch...... & 1,000 plants.... & 2 to 3 ounces. & $21 / 2$ feet. ..... & 2 feet \\
\hline Cabbage, & , January-April..... & 105 days. & $1 / 2$ inch. & 1,000 & 2 to 3 ounces. & feet. & $11 / 2$ feet \\
\hline ;e, Inte.... & $\left\{\begin{array}{l}\text { January-April..... } \\
\text { July-October.... }\end{array}\right\}$ & 150 & $1 / 2 \mathrm{i}$ & 1 & ces. & $42 / 2$ reet...... & 2 feet \\
\hline $\begin{array}{l}\text { Cole } \\
\text { Col } \\
\text { Cor } \\
\text { Cor } \\
\text { Cua } \\
\text { Dar }\end{array}$ & 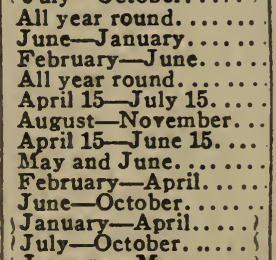 & $\begin{array}{l}60 \text { to } 90 \text { days. . } \\
150 \text { days...... } \\
6 \text { months. ...... } \\
100 \text { days. } \\
80 \text { to } 100 \text { days. } \\
100 \text { days....... } \\
120 \text { days....... } \\
6 \text { months. } . . . . \\
150 \text { to } 160 \text { days. } \\
100 \text { days....... } \\
90 \text { to } 120 \text { days. }\end{array}$ & $\begin{array}{ll}1 / 2 & i \\
1 / 4 & i \\
1 / 3 & i \\
1 / 2 & i \\
1 & i \\
1 / 2 & 1 \\
1 & i \\
1 / 2 & 1 \\
1 / 4 & i \\
1 / 2 & i \\
1 / 2 & i\end{array}$ & $\begin{array}{l}100 \mathrm{f} \\
1,000 \\
2,000 \\
400 \mathrm{f} \\
11 \mathrm{~b} \\
50 \mathrm{fe} \\
100 \mathrm{f} \\
200 \mathrm{f} \\
1,000 \\
100 \mathrm{f} \\
1,000\end{array}$ & 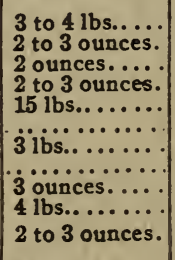 & 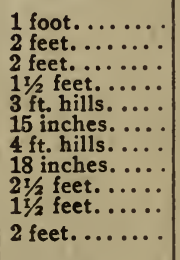 & $\begin{array}{l}3 \text { to } 4 \text { inches } \\
1 \mathrm{t} / 2 \text { feet } \\
6 \text { inches } \\
11 / 2 \text { feet } \\
2 \mathrm{ft} \text {. hills } \\
4 \text { to } 6 \text { inches } \\
4 \text { ft. hills } \\
8 \text { inches } \\
21 / 2 \text { feet } \\
8 \text { inches } \\
11 / 2 \text { feet }\end{array}$ \\
\hline 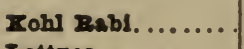 & $\left\{\begin{array}{l}\text { January-May....... } \\
\text { July-October..... }\end{array}\right\}$ & 120 & $1 / 2$ & . & & $\cdots \cdots$ & \\
\hline 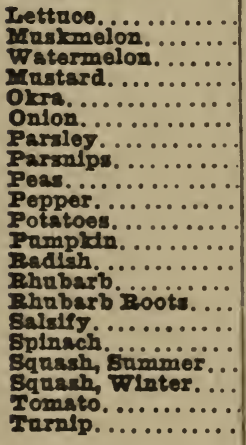 & 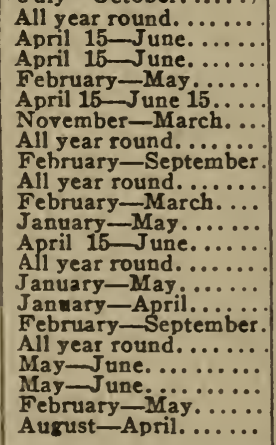 & 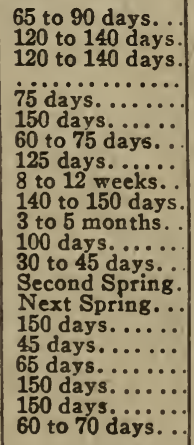 & 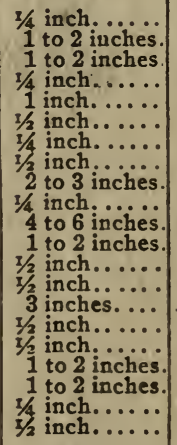 & $\begin{array}{l}200 \mathrm{f} \\
400 \mathrm{f} \\
200 \mathrm{f} \\
1 \mathrm{lb} \\
1,000 \\
8 \mathrm{lbs} \\
20 \mathrm{hi} \\
100 \mathrm{f} \\
200 \mathrm{f}\end{array}$ & 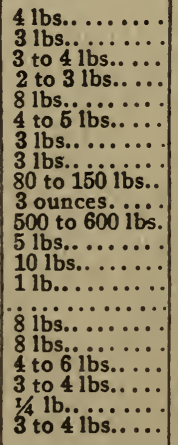 & 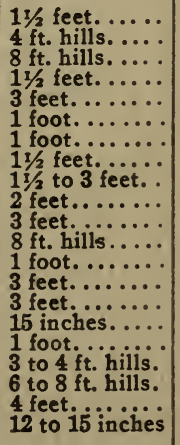 & $\begin{array}{l}6 \text { inches } \\
4 \text { ft. hills } \\
8 \text { ft. hills } \\
3 \text { inches } \\
11 / 2 \text { feet } \\
4 \text { inches } \\
6 \text { inches } \\
8 \text { inches } \\
2 \text { inches } \\
11 / 2 \text { feet } \\
15 \text { to } 18 \text { inches } \\
8 \text { ft. hills } \\
1 \text { to } 2 \text { inches } \\
3 \text { feet } \\
3 \text { feet } \\
3 \text { inches } \\
3 \text { inches } \\
3 \text { to } 4 \text { ft. hills } \\
6 \text { to } 8 \text { ft. hills } \\
4 \text { feet } \\
3 \text { to } 4 \text { inches }\end{array}$ \\
\hline
\end{tabular}

Of the abore all are planted out of doors except Egg Plant, Peppers and Tomatoes, which should be started early in frames or in the bouse and transplanted out of doors about the first of May. 


\section{HOW TO GROW VEGETABLES}

\section{ARTICHOKE}

One ounce will sow 200 feet of row, and produce about 500 plants. Six ounces will plant an acre. A deep rich sandy loam is best adapted for this plant. The seed should be sown thinly in drills $1 \frac{1}{2}$ inches deep and 1 foot apart. When large enough transplant to permanent rows 3 feet apart, allowing 2 feet between the plants. They reach maturity the second year, and in the northern states should be protected in winter by a covering of leaves or coarse manure. A bed will continue bearing for several years.

Jerusalem, or Tuberous-Rooted Artichoke. Entirely distinct, and grown exclusively for their large potata-like roots, which are valuable for feeding hogs, the yield often exceeding 2 tons per acre. They need not be dug, but the hogs can be turned into the field to root them up; 1 acre will keep 20 head in good condition until spring.

\section{ASPARAGUS}

One ounce will sow 50 feet of row, and produce about 800 plants. Four to five pounds will plant an acre. Sow the seed early in spring in drills 12 to 14 inches apart, and when well started thin out to 3 inches apart. When one or two years old transplant into permanent beds, thoroughly trenched, 2 feet or more in depth. Set the plants in rows 2 feet apart, and not less than 18 inches apart in the row. Care should be taken that the roots are well spread, and set at a depth of 6 inches below the level of the bed. Cover only 2 or 3 inches, and fill in gradually as the plants grow. Very little, if any, should be cut the first year after transplanting, but a fair crop can be cut the second year. Every fall after the tops have been cut down apply a dressing of coarse manure, and in the spring fork it in. An occasional top-dressing of salt at the rate of $1 / 2$ pound per square yard is also beneficial, and keeps down the weeds.

\section{ASPARAGUS ROOTS}

A saving of one or two years is effected by planting roots. A bed 12 by 40 feet, requiring about 100 roots, should give a sufficient supply for an ordinary family. If planted in rows 3 feet apart and 2 feet between the plants, 7,260 roots will plant an acre.

\section{BEANS}

Beans should not be sown until April 15th, or until all danger from frost is over, and for a continuous supply should be planted every four weeks until August. A warm, well drained, sandy loam is best suited. Sow the bush varieties in rows 2 feet apart and 3 inches apart in the row. Plant the pole beans 4 feet apart in hills and set a pole firmly in each hill. Sow 5 or 6 beans in a hill. Cover the seeds from 1 to 2 inches deep. One pound of the bush varieties will sow 100 feet of row and 35 pounds will plant an acre. One pound of the pole varieties will plant 100 hills and 25 pounds will plant an acre.

\section{LIMA BEANS}

Limas are very sensitive to cold and overmoist ground and should not be planted until May, when the soil has warmed up. Stick the seed edgewise with the eye down into the soil, covering the seed 1 to 2 inches deep. See that the ground is moist so that the beans will not require any watering until the seeds have sprouted, otherwise they are apt to rot. Sow the bush varieties in rows 2 feet apart and 5 inches apart in the row. Plant the pole beans 4 feet apart in hills and set a pole firmly in each hill. Sow 5 or 6 beans in a hill. Plant in a rich, mellow soil and cultivate frequently. One pound of the bush varieties will sow 100 feet of row and 1 pound of the pole varieties will plant 75 hills.

\section{BEETS FOR TABLE USE}

One ounce will sow 50 feet of drill; 5 pounds will plant an acre, and will mature in 65 to 75 days. Rich deep soil, not too recently manured, is best for this crop; sow about 1 inch deep in drills 15 inches apart, and when well established thin the plants to 6 inches apart in the rows. Beets can be planted any time of the year.

\section{MANGEL WURZEL AND SUGAR BEETS Largely Grown for Feeding Stock}

Five or six pounds will plant 1 acre, and will mature in about 150 days. The seed should be planted in rows 2 feet apart and thinned to 8 inches in the rows. To obtain the best results from this crop, use deep soil, well plowed; if the soil is thin a liberal application of a reliable chemical fertilizer is necessary. 


\section{BROCCOLI}

Broccoli is a very late hardy Cauliflower. The culture is easy and the heads mature at a time when garden vegetables are scarce. By sowing the different kinds in open beds in July so that well grown plants can be had for transplanting during September, it is possible to secure a succession of fine white heads from January to April. The plants require abundant irrigation and make most of their growth during late fall. One ounce will produce 1,000 plants. Sow the seed $1 / 2$ inch deep and transplant to rows $21 / 2$ feet apart and $11 / 2$ feet apart in the row. Cultivate the same as cabbage.

\section{BRUSSELS SPROUTS}

One ounce will produce 1,000 plants and will mature in about 150 days. Sow as directed for cabbage, and set the plants in rows $2 \mathrm{I} / 2$ feet apart and 2 feet apart in the rows. They require a long season of growth, but with suitable soil and liberal manuring an excellent crop of this vegetable can be secured. Cultivate the same way as cabbage.

\section{CABBAGE}

It is difficult to give definite cultural directions for cabbage, since it is possible to have good cabbage at all sea sons of the year in some parts of the country. Seed may be planted almost any time of the year. Howerer, there are three seasons preferable for sowing-in September for early spring cabbages, from January to April for summer and fall cabbages, and July to August for winter cabbages. Sow the seed $1 / 2$ inch deep and transplant the early varieties to rows 24 inches apart and 18 inches apart in the rows. They will mature in about 105 days. The late varieties mature in about 150 days and should be planted in rows 30 inches apart and 24 inches apart in the row. To prevent the heads from splitting open before they are reads to be harvested, the plants should be loosened a little at the root. Cabbages require plenty of moisture, but too much water causes them to rot rery readily.

\section{CAULIFLOWER}

Culture same as cabbage. Soil must be rich and deep, and the plants liberally supplied with water in dry weather. As the flower heads appear, the large leaves should be broken down over them to protect them from the'sun and rain. One ounce will produce 1,000 plants and will mature in about 150 days. Sow from June to January.

\section{CELERY}

Sow the seed $1 / 8$ inch deep in open ground as soon as fit to work in April, or for very early use in hot bed or cold frame. Pressing in the seed has often been found more satisfactory than covering. Cut the tops off once or twice before planting out, to make them stocky. When the plants are 5 or 6 inches high, transplant to rows 2 feet apart and set the plants 6 inches apart in rows. Water freely and shade from sun until established. Cultivate well, and when large enough blanch by earthing up or by partly shading the rows with boards. One ounce to 2,000 plants; will mature in about 6 months.

\section{CARROTS}

Best results are obtained when carrots are planted in a rjch, deep, sandy loam, well pulverized and deeply cultivated. For an early crop sow in March and April in drills about 1 foot apart, thimning out to 4 inches in the row; sow for main crop in August and September. The large late varieties for field culture should be sown in drills 3 to $3 \mathrm{r} / 2$ feet apart, so as to cultivate by horse. An important point in sowing carrots, as in all other seeds, is to tread the row firmly after sowing. One ounce will sow over 100 feet of drill; 3 to 4 pounds for 1 acre. For garden purposes sow any time.

\section{CELERIAC OR TURNIP ROOTED CELERY}

Sow seed same as celery, transplant into rows 2 feet apart and about 6 to 8 inches in the row. No earthing up is required for celeriac, as it is the roots which are the edible part of the vegetable. For winter use, pack in damp sand or earth in cellar, or cover with straw and earth outside.

\section{CHERVIL}

May be planted any time in the early spring. The leaves should be kept cut, and if not allowed to run to seed, will keep green for a long time. Is more finely curled than parsley, and makes an excellent plant for garnishing. One ounce will plant 100 feet of row. Sow seed $1 / 2$ inch deep. 


\section{CHICORY}

Used as substitute for coffee when the roots are dried and ground. The roots are also used for cooking, and are rery palatable. Sow the seed $1 / 2$ inch deep early in the spring, thin the roung plants to 6 inches and keep well hoed. The plant spreads from the root and is perennial; will mature in 120 dars. One ounce will sow 400 feet of row; 4 pounds will plant an acre.

\section{COLLARDS}

A plant bearing a large mass of leares on the top of a stout stalk. It is a species of cabbage, and the flaror is the same. It bears leaves all through the winter, and is used especially in the South for cabbage greens. Young plants may be started in boxes in early spring, and then transplanted to $1 \mathrm{I} / 2$ feet apart each way, hoe often. One ounce will plant 400 feet of row.

\section{CORN SALAD OR FETTICUS}

A salad plant used as a substitute for lettuce in salads, or mạ be cooked like spinach for greens. It does well in winter and spring and matures in about 100 days. On rich soil the leaves grow quickly and are exceedingị tender.

Sow from August to November in drills $1 / 2$ inch deep and thin out to 6 inches apart. Tread it lightly to secure germination.

\section{SWEET OR SUGAR CORN}

Corn is sensitive to frost and is liable to rot in cold or wet ground. Plant in April or Mar, or when the ground has become warm. It will mature in 80 to 100 days and can be planted until Juls, in hills 2 by 3 feet apart. Cover 8 or 10 seeds about 1 inch deep; thin out to 3 plants to a hill. Plant in a rich moist soil; hoe and cultivate frequently. One pound will plant 100 hills, and 15 pounds will plant an acre.

Field corn should be planted in hills 4 feet apart each was; use 10 pounds to the acre.

\section{CUCUMBERS}

One ounce will plant 100 hills; 3 pounds will plant 1 acre. Cucumbers succeed best in a rich, loam soil and should be planted in May when the ground has warmed up. Plant the seed in slightly raised hills, 4 feet apart each way, place 6 or 8 seeds in each hill in a circle and cover with one inch of fine soil. After the plants are well started thin out to four. Cucumbers thrive well on well rotted compost and a shovelful of old manure should be placed 6 inches deep under each hill and firmly tramped down. Have the soil moist before planting so that no watering is required until the seeds have sprouted, otherwise they are apt to rot. After they commence to set fruit, water freely by sprinkling rines for about 10 minutes evers other day or so. Thes mature in 120 dass.

\section{CRESS OR PEPPER GRASS}

Used as a salad, either alone or mixed with other greens; also used for garnishing. Sow thickly in shallow drills about 1 foot apart.

\section{WATERCRESS}

"This is sown by the side of running water. It is altogether an aquatic plant and forms an early and wholesome spring salad.

\section{DANDELION}

One ounce will sow 200 feet of drill. It will mature in six months and should be sown in Mar and June in drills 18 inches apart and $1 / 2$ inch deep. The leaves are best for salads when blanched, by partly shading the rows with boards.

\section{EGG PLANT}

One ounce will produce 1,000 plants. A strong, uniform heat is required to germinate the seeds. and a thoroughly pulrerized, well-enriched, warm soil is necessary to perfect the fruit. Sow the seed from January to March $1 / 4$ inch deep and transplant when all danger from frost is over $2 \mathrm{I} / 2$ feet apart each was, and when about a foot high, support the plants by drawing the earth up around them. Egg plants mature in 150 to 160 dars.

\section{ENDIVE}

One ounce will sow 100 feet of drill. Sow the seed $1 / 2$ inch deep in any ordinary soil from June to October in drills $1 \frac{1}{2}$ feet apart, covering lightly. When the plants are about 2 inches high, thin to about 8 inches in the row. When the plants have attained full size, gather up the leares, tring together at the tips. This excludes the air from the inner leares, which in the course of three or four weeks will become blan hed. 


\section{KALE OR BORECOLE}

This plant is useful for furnishing a large supply of greens for boiling during the early fall, winter, and spring months. Sow the seed thinly in drills, transplanting to rows 2 feet apart when of sufficient size. Sow as directed for cabbage. One ounce will produce 1,000 plants; 2 to 3 ounces will plant an acre.

\section{KOHL RABI-TURNIP ROOTED CABBAGE}

One ounce will produce 1,000 plants. Sow the seed $1 / 2$ inch deep in rows 18 inches apart, afterwards thinning to 8 or 10 inches. The bulb is the edible part and when cooked tastes very much like turnip. Kohl Rabi will mature in 120 days and may be sown from January to May and from July to October.

\section{LEEK}

Sow from January to April, in drills 1 foot apart and $1 / 2$ inch deep. When the plants are 6 to 8 inches high transplant in a deep, rich soil, in rows 12 inches apart and 4 inches in the rows, as deep as possible, so that the neck may be covered and blanched; draw the earth to them as they grow. The seed may also be sown in July or August for good plants in the fall and winter. One ounce will plant 200 feet of row; 4 pounds will plant an acre.

\section{LETTUCE}

Lettuce seed should be covered very lightly to secure germination. When well started transplant to rows 18 inches apart and 6 inches apart in the row. It may be planted throughout the season in most localities, and will mature in 65 to 90 days according to the variety and season of planting. One ounce will sow 200 feet of row; 4 pounds will plant an acre.

\section{MUSHROOM SPAWN}

Ten pounds will spawn about 10 feet square. Mushrooms can be grown in any dark room or cellar where the temperature can be kept at from 50 to 70 degrees. From some old pasture procure good, rich soil, and to every bushel of this soil add 2 bushels of fresh horse manure. Of this well-mixed compound prepare a bed, say, 4 feet wide. Put down a thin layer and pound it down hard, and go on until you have a bed 12 or 18 inches thick. As soon as the temperature of the bed falls from 75 to 50 degrees, the spawn may be inserted in pieces about the size of a walnut, about 2 inches deep and 6 inches apart. Cover with loamy soil about 2 inches deep and beat it down evenly and firmly. Finish off with a covering of clean hay, about a foot thick, and the work is done. If the temperature is right, in 6 or 8 weeks you may expect mushrooms. The beds will continue bearing from 20 to 30 days.

After the first crop is gathered spread over the bed an inch of fresh soil, moisten with warnı water, and cover with hay as before. The main conditions in mushroom growing are proper and uniform temperature and very rich soil.

\section{MUSKMELON}

One ounce will plant 80 hills; 3 pounds will plant an acre. A light, warm, rich soil is essential for this crop. When all danger from frost is over, plant the seed in slightly raised hills 4 feet apart each way, placing 6 to 8 seeds in each hill in a circle and covering with one inch of fine soil. Place a shovelful of old manure about 6 inches under each hill and tramp down firmly. Have the soil moist before planting so that no watering is required until the seeds have sprouted, otherwise they are apt to rot. After all danger of destruction by bugs is over, thin out to 3 plants to a hill; when about 1 foot long pinch off the tips to make them branch. This strengthens the growth of the vines and makes the fruit mature early. Muskmelons mature in 120 to 140 days.

\section{WATERMELON}

One ounce will plant 35 hills; 3 to 4 pounds will plant an acre. The culture of watermelons differs from that of muskmelons mainly in that the hills should be wider apart, from 8 to 10 feet, according to the variety grown. An effort should be made to secure good strong vines early in the season, and this can best be done by taking care that the hills are large, mellow, and well drained, with the manure placed so that they will not dry out quickly under hot suns. Plant the seeds thickly when danger of frost is over and thin the plants to four of the strongest in each hill. All possible protection from insects should be given the young plants and their growth may be still further hastened by frequent application of liquid manure. They mature in 120 to 140 days. As a protection from insects, netting is frequently used. 


\section{OKRA OR GUMBO}

This vegetable is extensively grown for its green pods, which are used in soups, stews, etc., and matures in about 75 days. Sow the seed thickly in rich ground about the middle of May, or when the ground has become warm, until June, in drills 3 feet apart, 1 inch deep; thin to 18 inches apart in the drills.

\section{ONION}

The best onions are grown on low, sandy, or mucky lands, with natural moisture, and plenty of it. Higher lands can be used if irrigated, provided the land is rich and very well worked before planting the seed. Onions do not follow a hay or grain crop to good advantage, since the soil lacks nitrogen and humus. A piece of land contemplated for onions should be planted to beans, peas, or some other vegetable crop one or two years.

On high lands the seed should be sown in December or early in January, while on low lands any time from February 1st to March 10th will do, depending on the condition of the weather. Sow in rows from 12 to 16 inches apart, using 4 to 5 pounds of seed for an acre. In irrigating onions, it is important that the land never be allowed to get dry, for a check in the growth will either force the plant to run to seed or will make stiff necks. In the home garden plant early in rows one foot apart and thin to 4 inches apart in the row. Sow the seed $1 / 2$ inch deep, using one ounce to 200 feet of row. Onions mature in about 150 days.

\section{PARSLEY}

Used for garnishing and seasoning soups, meats, etc. Succeeds best in a mellow, rich soil. Sow thickly at any season in rows 1 foot apart and $1 / 4$ inch deep; thin out plants to stand 6 inches apart in the rows. The seed is slow of germination, taking from three to four weeks to make its appearance, and often failing to come up in dry weather. To assist its coming up quicker, soak the seed a few hours in warm water, or sprout in damp earth, and sow when it swells or bursts. One ounce will sow 400 feet of row; 3 pounds will plant an acre.

\section{GARDEN PEAS}

A light, moderately rich soil is best for peas. For early peas sow in the fall, and for successive crops plant until July. Plant the dwarf varieties in single or double rows 18 inches apart and about 2 inches apart in the row. The tall sorts should be planted in rows 3 feet apart. Sow the seed 2 to 3 inches deep, and in dry weather soak the seeds for 5 or 6 hours in water before planting. One pound will sow 100 feet of row, and 80 to 150 pounds will plant an acre. Peas mature in 8 to 12 weeks.

\section{PEPPER}

Peppers are indispensable as a seasoning for soups and meats. The large varieties are mainly used for this purpose and for pickling. The mild, sweet varieties, like Sweet Mountain and Bell, are used for Mangoes, while the small-fruited sorts are the best for sauces. They mature in 140 to 150 days. Sow $1 / 4$ inch deep in hotbeds in February or March, and, when danger from frost is over, transplant in rows 2 feet apart and 18 inches in row, in good rich ground.

\section{PARSNIPS}

One ounce will sow 200 feet of drill; 3 pounds will plant an acre. This crop requires a very rich soil. Sow from February to September in drills 18 inches apart and $1 / 2$ inch deep, and thin to 8 inches to the row. Besides being desirable as a vegetable they are valuable for feeding stock, and mature in 125 days.

\section{PUMPKIN}

One ounce will plant 20 hills; 5 pounds will plant an acre. Plant after all danger of frost is over, until June, in hills 6 to 8 feet apart each way, covering seed 1 to 2 inches deep, allowing 3 strong plants to a hill. In other respects they are cultivated as melons and cucumbers; keep separate from melons and cucumbers, as they are liable to mix. Pumpkins mature in about 100 days.

\section{POTATOES}

The soil best suited to the potato is a rich, sandy loam, but it seems to thrive in almost any soil or climate. The potato, being a gross feeder, requires a liberal application of manure or bone meal; if stable manure is to be used, it should be well rotted, and not allowed to come in contact with the tubers. Use at the rate of 500 to 600 pounds to the acre. Plant as early in the spring as the ground can be thoroughly worked, in rows 3 feet apart and 15 inches in the rows for early potatoes and 18 inches apart for late ones; covering in light warm soil about 6 inches, and in heavy soil about 4 inches deep; draw the earth to the plants as they advance in growth. Eight pounds will plant 100 feet of row. Cut the tubers up in good-sized pieces each containing not less than two or three eyes; they are sometimes cut up a day before planting so as to allow the cut portions to become calloused. 


\section{RADISH}

Radishes thrive best in a light, rich, mellow soil, and to bring out their mild qualities they must make a quick and tender growth. Sow early in spring and well into summer for succession, in well-manured, deeply dug and finely raked soil; if not well stimulated into a rapid growth, they become fibrous and tough; sow in drills 10 inches apart and $1 / 2$ inch deep, and thin to 2 inches in the rows. Sow at intervals of two or three weeks until September for a succession. They mature in 25 to 40 days. Sow winter varieties in July and August; like the turnip, they make the best growth in autumu, and must be taken out before serere frost, and stored away in a cool cellar in sand, where they will keep tender and crisp all winter, before using put in cold water, which adds to the freshness. One ounce will sow 100 feet of row, 10 pounds will plant an acre.

\section{RHUBARB}

Sow in drills $1 / 2$ inch deep; thin out to 6 inches apart. In fall, trench a piece of ground and manure it well and then transplant the soung plants into it 3 feet apart each way. Cover with leaves or litter the first winter, and a dressing of manure should be given every fall. It is better to plant strong roots, as they will produce next spring. One ounce will sow 200 feet of row.

\section{SALSIFY OR OYSTER PLANT}

One ounce will sow 100 feet of row; $S$ pounds will plant an acre. The soil should be rich and well worked to a depth of at least 18 inches. Sow in drills 15 inches apart, covering the seeds with fine soil $1 / 2$ inch in depth. When the plants are strong enough, thin them out to about 3 inches apart. The seed may be sown from February to September and will mature in 150 days.

\section{SPINACH}

One ounce will sow 100 feet of drill; 8 pounds for an acre. Select very rich, well-drained soil, sow in drills 1 foot apart and $1 / 2$ inch deep. For spring and summer use make the first sowing early in spring and continue at intervals for two or three weeks, until the middle of June; sow in August and September for winter and early spring use; will mature in about 45 days.

\section{SQUASH}

Squash should be planted in a warm, rich soil, after the weather has become settled and warm, about the beginning of May or June. Plant in well-manured hills, in the same manner as cucumbers or melons-the bush varieties 3 or 4 feet apart each way, and the running kinds from 6 to 8 feet. 8 to 10 seeds should be sown, 1 to 2 inches deep, in each hill, thinning out after they have attained their rough leaves and danger from bugs is over, leaving 3 or 4 of the strongest plants to a hill. The soil should be moist before planting so that no watering is required until the seeds have sprouted, otherwise they may fail to germinate. An occasional feeding of liquid manure will repay in size of fruits. One ounce will plant 35 hills of the bush varieties. Four to six pounds is required to an acre. One ounce will plant 15 hills of the Winter varieties, and 3 to 4 pounds is required to an acre. Summer sorts mature in 65 days and the winter sorts in 150 days.

\section{TOMATO}

For early plants sow in hotbeds early in March or April, in drills 5 inches apart and $1 / 4$ inch deep; when the plants are about 2 inches high, transplant into another hotbed 4 inches apart each way; plant out in the open ground early in May, or as soon as danger from frost is over, 4 feet apart each way in hills, which should have a shovelful of well-rotted manure mixed with the soil. Water freely at time of transplanting, but after the plants are well established water sparingly and at the roots only, as spraying the vines and overwatering causes the blossoms to drop off; wlien the first fruit is set, pinch off the ends of the branches to obtain early fruit. Sufficient plants for a small garden can be grown in a shallow box by placing it in a sumn window in a warm room. For late use sow in a sheltered border in May, and set out the plants in July; the green fruit can be picked off before frost and ripened under glass. By training the vines on trellises or tying to stakes, the fruit will ripen better and be of finer quality. The fruit matures in 150 days.

\section{TURNIP}

For early use, sow in January and February, in drills from 12 to 15 inches apart, covering the seed $1 / 2$ inch deep; thin out to 3 or 4 inches in the rows. For succession, continue to sow every two weeks until June; for fall and winter crop, sow in July and August. The Ruta Bagas are grown for feeding stock and are also excellent for the table. Take up the roots in November, or before severe frosts; cut off tops within an inch of the crown, store in cool cellar or pit. One ounce will sow 200 feet of row; 3 to 4 pounds will plant an acre; they mature in 60 to 70 days. 


\section{Hallawell's "Quality" Seeds}

We prepay charges anywhere within the fourth parcel post zone on all vegetable, flower, field and grass seeds in packets, ounces, 1-pound and 10-pound lots. In quantities of twenty-five pounds and over, special prices will be made where not already listed which do not include free delivery. Fertilizers, insecticides, tools and nursery stock are not prepaid except where specially stated.

FOR FOREIGN ORDERS, add postage at the rate of 12 cents per pound. All orders for foreign countries are packed carefully and are sent by insured mail when possible. Shipment, however, is made at customer's risk.

\section{ARTICHOKE}

(For cultural directions see page 1)

We can furnish selected plants of French Green Globe Variety from January 1st to May 1st. Price 15c each; $\$ 1.50$ per dozen (postpaid within 2nd zone).

ARTICHOKE SEED_Large Green Globe. Pkt., 15c; oz., 90c.

It is adrisable to set out plants in preference to seed as the seed usually produces a rery large percentage of sping fruit.

JERUSAIAM OI TUBEROUS-ROOTED ARTICHOKEPer 1b., 20c; 10 lbs., $\$ 1.50$.

\section{ASPARAGUS}

(For cultural directions see page 1)

MARY WASHINGTON-A new rariet 5 which has proven to be nearly rust free. The plants form large, thick, heary shoots which are dark green and of fine flaror; a heàry yielder. Pkt., 10c; 0z., 50c; I/4 1b., \$1.50; lb., $\$ 5.00$.

Roots, 35c per doz.; $\$ 2.25$ per 100 , postpaid within 2nd zone; $\$ 2.00$ per 100 by express.

PALMETTO-A very early maturing and prolific variety, producing an abundance of very large deep green shoots of the best quality. Pkt., 10c; 0z., 20c; I/4 lb., 15c; lb., \$1.25.

Roots, 35c per doz.; $\$ 2.25$ per 100, postpaid within 2nd zone; $\$ 2.00$ per 100 by express.

\section{BEANS}

(For cultural directions see page 1)

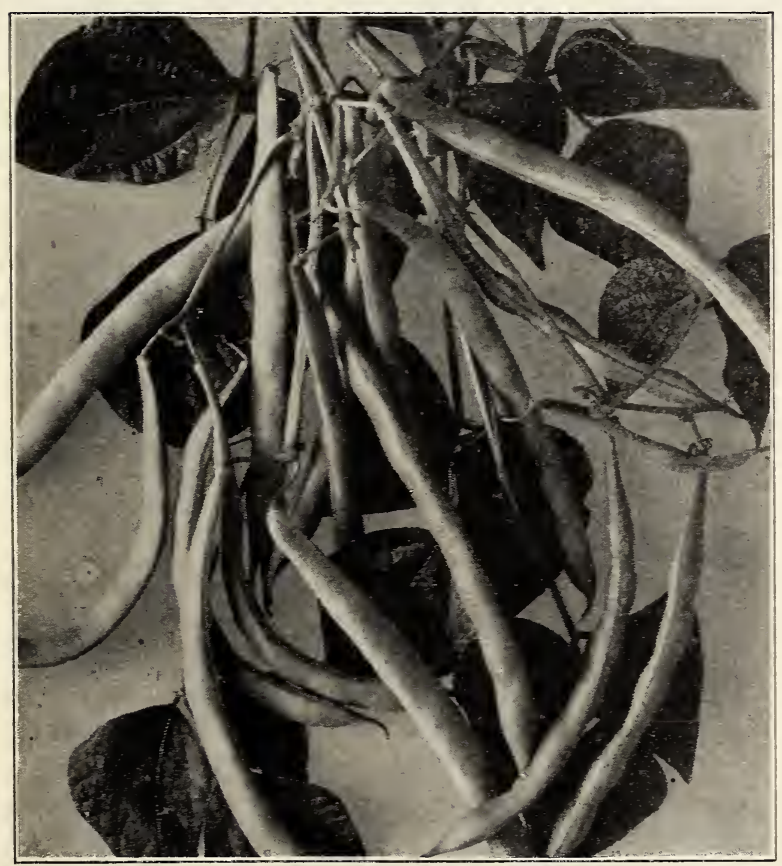

Masterpiece Beans

MASTERPIECE-A thrifty, healthy grower, producing an abundance of large green pods which are remarkabiy straight, broad, thick and of excellent quality. Pkt., 20 c; 1b., 75c.

\section{Dwarf Green \& Wax Podded}

BOUNTIFUL - An earls, hard $\bar{y}$ and productive variet $y$, bearing thick, flat, light green pods of fine quality. Pkt., 10c; 1b., 50c; 10 lbs., \$1.50.

STRINGLESS GREEN POD-One of the earliest rarieties. Pods round, long and quite stringless. vers crisp and tender. Pkt., 10c; 1b., 50c; 10 lbs., $\$ 1.50$.

CANADIAN WONDER-Pods are flat, of great length and very tender. Pkt., 10c; 1b., 50c; 10 lbs., \$4.50.

REFUGEE or 1000 to 1 -A popular variet 5 for late planting. with large, tender pods, very productive. Pkt., 10c; lb., 50c; 10 lbs., \$1.50.

BROAD WINDSOR or HORSE BEANS-Used extensirely for stock feed and for cover crops. Lb., 25c; 10 1bs., $\$ 2.00$. (Write for special prices on large quantities.)

BROAD WINDSOR, JOHNSON'S WONDERFUL LONG POD-The best variets for table use. Pods are very long and the beans green and tender; endures frost. Imported seed. Pkt., 10c; 1b., 50c.

FRENCH STRING BEAN-Matures verr earlr. Pods long, round. straight and of excellent qualiț. Pkt., 10c; lb., 50c; 10 lbs., $\$ 1.50$.

DWARF HORTICULTURAL OI CRANBERRY - Pods large, color green splashed with red, mostly used for shell beans. Pkt., 10c; 1b., 50c; 10 lbs., \$4.50.

DAVIS WHITE WAX-Of compact, upright growth, producing a large rield of handsome, long pods, of a clear waxy white color; quite stringless. Pkt., 10c; 1b., 50c; 10 lbs., $\$ 1.50$.

IMPROVED GOLDEN WAX-The golden rellow pods average 5 inches long; brittle and entirely stringless. Pkt., 10c; lb., 50c; 10 lbs., $\$ 1.50$. 


\section{Beans-Continued}

All charges are postpaid anywhere within the fourth zone.

\section{BEETS}

(For cultural directions see page 1)

\section{Pole Beans}

\section{Green and Yellow Podded}

BURGER'S POLE-In some sections this is called White Seeded Kentucky Wonder. Bears long, brittle pods of excellent quality, entirely stringless. Pkt., 10c; lb., 40c; 10 lbs., \$3.50.

HORTICULTURAL OR SPECKLED CRANBERRY - Popular old variety. Pods j inches long. pale green, but become streaked with red when mature. Pkt., 10c; 1b., 35c; 10 lbs., \$3.00.

KENTUCKY WONDER-The most popular pole bean in cultivation. The medinm sized, silvery green pods hang in great clusters from top to bottom of pole. Entirely stringless. Pkt., 10c; lb., 35c; 10 lbs., $\$ 3.00$.

KENTUCKY WONDER WAX - An exceedingly productive variety, bearing a large quantity of rich golden yellow pods which are thick, stringless and very tender. Pkt., 10c; 1b., 40c; 10 lbs., \$3.50.

SCARLET RUNNER - A great favorite; botl ornamental and useful; producing dazzling scarlet flowers during the summer months. Pkt., 10c; lb., 35c; 10 lbs., $\$ 3.00$.

WHITE CREASEBACK-An early variety borne in clusters. Porls 5 inclies long, of fine quality and very productive. Pkt., 10c; 1b., 35c; 10 lbs., $\$ 3.00$.

\section{Bush Lima Beans}

BURPEE'S BUSH LIMA-The dark green pods are $4 \frac{1}{2}$ inches long and contain 3 or 4 good sized beans of good quality, very productive. Pkt., 10c; lb., 35c; 10 lbs., $\$ 3.00$.

BURPEE'S IMPROVED BUSH LIMA-Plants uniformly dwarf and enormously productive. Pods large containing 4 to 6 large thick beans of superior quality. Pkt., 10c; lb., 35c; 10 lbs., $\$ 3.00$.

FORDHOOK BUSH LIMA-A greatly improved form of Dreer's Busli Lima, producing large landsome pods, each containing 4 to 5 beans which retain their flavor throughout the season. The plants are of uprightgrowtli and very productive. Pkt., 10c; 1b., 40c; 10 lbs., $\$ 3.50$.

HENDERSON'S BUSH LIMA-Valuable for its earliness. Porls short rontaining 2 to 4 beans of excellent quality. Vines continne to grow and set pods until frost. Pkt., 10c; lb., 35c; 10 lbs., \$3.00.

\section{Pole Lima Beans}

EARLY LEVIATHAN - The earliest large pole Lima with long, broad pods, containing 5 to 6 beans of unexcelled quality, remarkably productive. Pkt., $10 \mathrm{c} ; 1 \mathrm{~b} ., 35 \mathrm{c} ; 10$ lbs., $\$ 3.00$.

KING OF THE GARDEN - A vigorous and productive sort, pods very long, each containing 5 to 6 large beans of delicious flavor. Pkt., 10c; lb., 35c; 10 lbs., \$3.00.

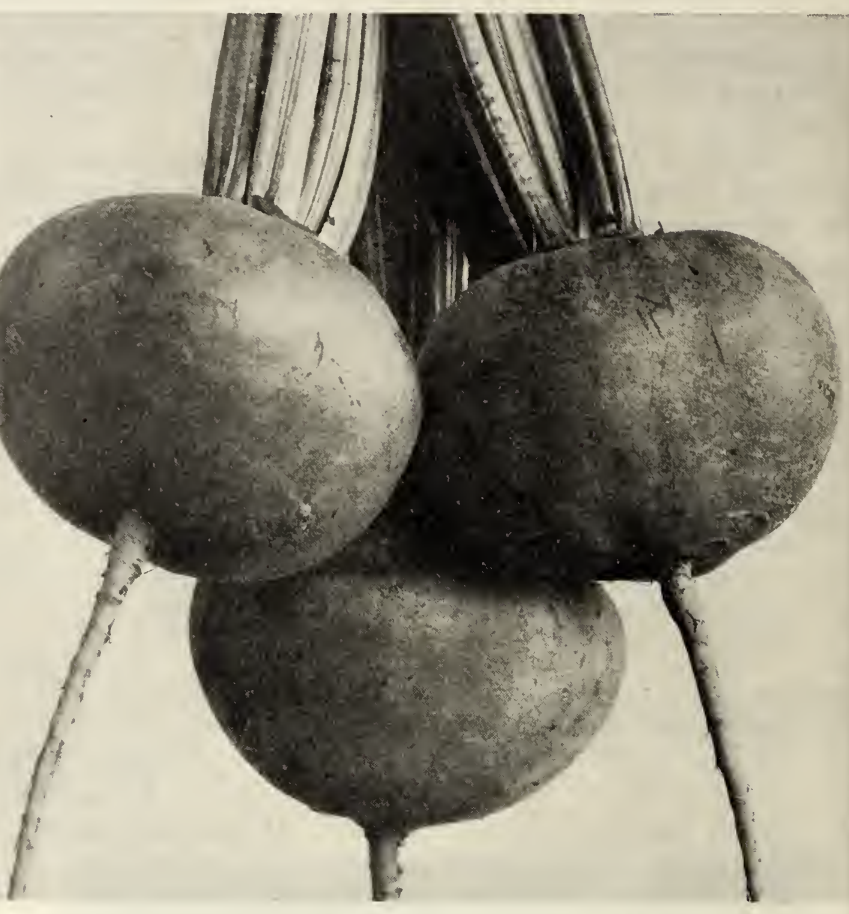

Improved Blood Turnip Beets

\section{Table Beets}

CROSBY'S EGYPTIAN-Extremely early and of fine quality. More globe-shaped than Extra Early Egyptian and of a rich vermilion color; is sweet and tender. The most popular variety. Pkt., 10c; oz., 20c; 1/4 lb., 45c; lb., $\$ 1.25$.

DETROIT DARK RED-An early globe-slaped variety; skin blood red and flesh rich red. Tops small and green. One of the best table varieties and of liandsome appearance. Pkt., 10c; oz., 20c; $1 / 4$ 1b., 45c; 1b., $\$ 1.25$.

EARLY WONDER -Globe-shaped and very uniform in size. skin smooth. Flesh deep blood-red and extremely tender. Pkt., 10c; oz., 20c; 1/4 lb., 45c; lb., \$1.25.

EXTRA EARLY EGYPTIAN-A turnip-shaped variety, with dark and light red flesh. Dark leaves. Very early and tender sort. Pkt., 10c; oz., 20c; 1/4 lb., 35c; lb., $\$ 1.00$.

IMPROVED BLOOD TURNIP - A selected strain of early blood turnip beet. Flesh is blood red and of excellent quality; remains in good condition for a long time; tops are green. Pkt., 10c; 0z., 20c; 1/4 lb., 35c; 1b., \$1.00.

LONG SMOOTH DARK BLOOD-The best of all Long Blood Beets. A very desirable variety for light sandy soils. Flesh dark blood red, exceedingly tender and sweet. Pkt., 10c; oz., 20c; $1 / 4$ 1b., 35c; 1b., $\$ 1.00$. 


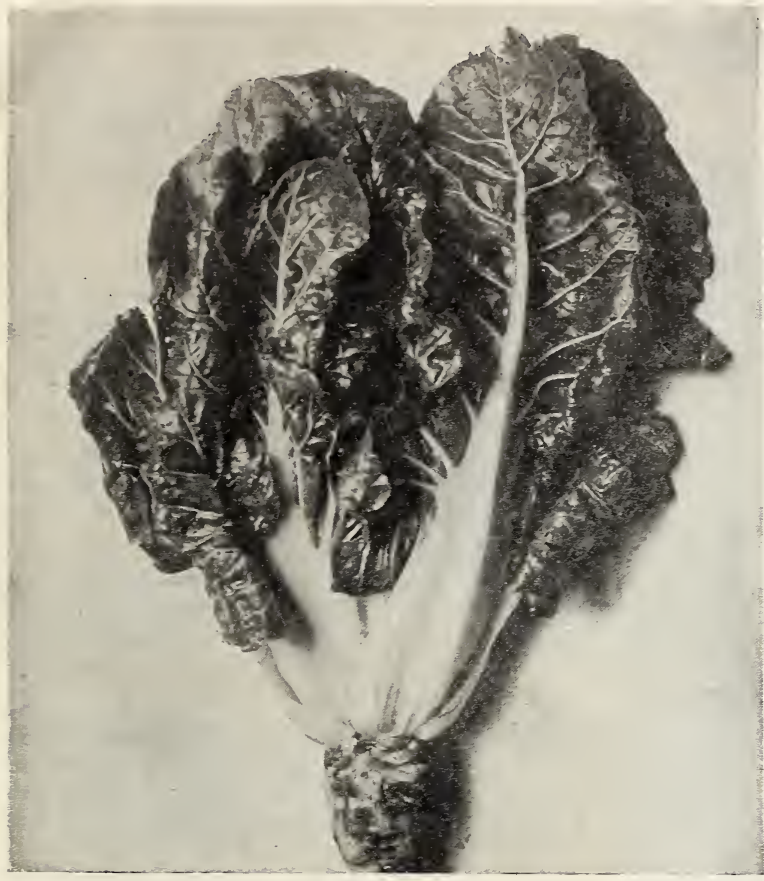

Improved Silver Swiss Chard

\section{Swiss Chard or Spinach Beet}

Used for greens; the leaf stalks are cooked as asparagus. IMPROVED SILVER-Large pale green leaves with white mid-rib. Pkt., 10c; oz., 20c; I/4 lb., 35c; 1b., $\$ 1.00$.

GIANT LUCULLUS-The largest and best variety of Swiss Chard. Seed planted in early spring will quickly produce plants from which euttings may be made all Summer. As soon as cut new shoots will spring up and make quick growth. If the plants are allowed to grow without cutting they will make large curly leares with thick light-colored mid-ribs which may be cooked like asparagus. Pkt., 10c; oz., 20c; I/4 lb., 35c; 1b., $\$ 1.00$.

\section{Mangel Wurzel or Stock Beet}

For main crop sow about March 1 st in rows 2 feet apart and thin to 8 inches apart in the row. Sow 6 pounds to I acre.

MAMIMOTH LONG RED_-The largest of the mangels and the heaviest cropper. The skin is red; flesh white zoned with red. This variety produces a larger amount of good feed than any other beet. Oz., 10c; 1b., 60c; 10 lbs., $\$ 5.50$.

GOLDEN TANKARD-This is a distinct and superior strain of the Yellow Mangel, being much finer and firmer in flesh and containing more sugar. On account of its peculiar shape, enormous crops are grown when plants are set out closer in the rows than the ordinary mangel crops. Oz., 10c; 1b., 60c; 10 lbs., \$5.50.

GIANT HALF SUGAR ROSE TOP-A very hardy variety, producing large crops with little care. The root is large and rery rich in sugar, and while not sufficiently so for sugar purposes, it makes a remarkably fine, rich food for stock. Pkt., 10c; lb., 60c; 10 lbs., $\$ 5.50$.

KLEIN WANZELBEN SUGAR_For sugar-making. Contains a large percentage of saccharine matter. $\mathrm{Oz}$., 10c; $\mathrm{I} / 4$ lb., $25 \mathrm{c} ; 1 \mathrm{~b} ., 75 \mathrm{c}$.

\section{BROCCOLI}

(For cultural directions see page 2)

CALIFORNIA WONDER-A vigorous long leaved plant with heary mid-ribs, is intermediate in type between the true Cauliflower and the Broccoli. Usually heads in Januars, but season can be varied by planting at different dates. Pkt., 15c; I/4 oz., 50c; oz., $\$ 1.50$.

ITALIAN GREEN SPROUTING-The heads or curds branch and are broken off and cooked like asparagus. Pkt., 25c.

ST. VALENTINE-Heads are large, solid, white and well protected with large leares. Matures in March. Pkt., $15 \mathrm{c} ; \mathrm{I} / 4$ oz., 50c; oz., $\$ 1.50$.

WHITSUNTIDE-The largest and best late sort. Matures in April and May. Pkt., 15c; I/4 oz., 50c; oz., \$1.50.

\section{BRUSSELS SPROUTS}

(For cultural directions see page 2)

DWARF PERFECTION-Grows 2 to 3 feet high and is well covered with small sprouts which are very solid and excellent in flaror. Pkt., 10c; oz., 30c; I/4 lb., 90c; lb., $\$ 2.75$.

\section{Cardoon}

LARGE SMOOTH-The best variety, grows about 4 feet tall. The leaves and stems must be blanched like celery to bring out the delicate flavor. Sow in Spring in drills 1 inch deep and when one-year old transplant into wellmanured ground in rows 3 feet apart and 1 foot apart in the row. Pkt., 10c; oz., 50c; $1 / 4$ lb., $\$ 1.50$.

\section{Chervil or Cerfeuil}

(For Cultural directions see page 2)

An aromatic sweet herb, vers finely curled and resembling parsley. The young leaves are used in soups and salads. Pkt., 10c; 0z., 25c; I/4 lb., 75c.

\section{Chicory}

(For cultural directions see page 3)

WHITLOOF-Known in restaurants as French Endive. The stalks when blanched make delicious salad. Sow in Mav and June in drills 10 inches apart. Transplant or thin to 6 inches; treat as endive, except that in late Summer or Fall it should be gradually banked up like celery. Pkt., 10c; 0z., 25c; I/4 lb., 75c.

LARGE-ROOTED MAGDEBURG-The roots when dried, roasted and ground are largely used as an adulterant or substitute for coffee. The young leaves are excellent as salad. Pkt., 10c; oz., 25c; I/4 1b., 75c.

Collards-See page 10.

Corn Salad-See page 10

\section{Cress or Pepper Grass}

(For cultural directions see page 3 )

EXTRA CURLED-Used as a salad either alone or mixed with mustard greens; rapid growing, dwarf and compact. Pkt., 10c; 0z., 20c; I/4 1b., 50c; 1b., \$1.50.

\section{Water Cress}

Highly esteemed for salads and garnishing. It must be grown along moist banks. Pkt., 10c; 0z., 75c. 


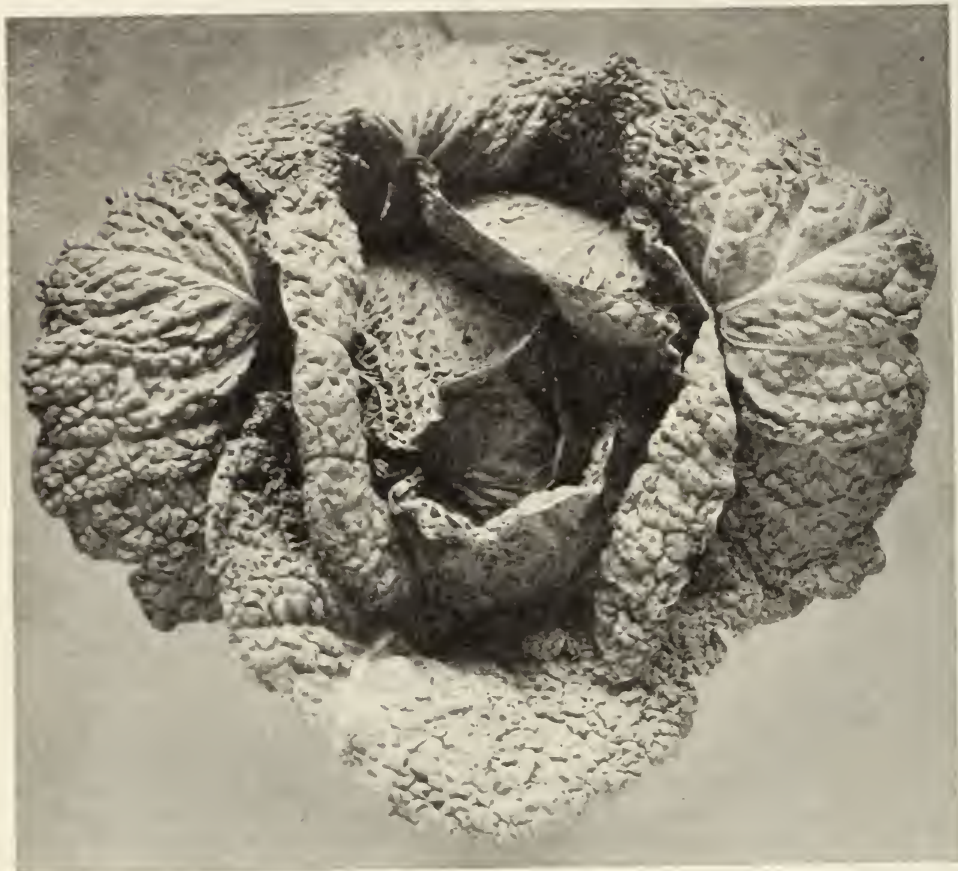

American Drumhead Savoy Cabbage

\section{Second Early Varieties}

EARLY DRUMHEAD - Good, solid, large round heads. Pkt., 10c; oz., 30c; $1 / 4 \mathrm{lb}$. $90 c ; 1 b ., \$ 3.00$.

EARLY DWARF FLAT DUTCH-Natures early and makes a large, solid, flat head, with short stems. Pkt., 10c; oz., 30c; $\mathrm{I} / 4 \mathrm{lb}$., 90c; lb., $\$ 3.00$.

\section{Winter Varieties}

DANISH BALL HEAD OR THE HOLLANDER - Very round, solid Winter sort. bluish green color; a good-keeping variety. Pkt., 10c; 0z., 35c; 1/4 1b., \$1.00; lb., \$3.50.

LARGE FLAT DUTCH-The best late variety in cultivation; large, round, flat, solid heads of perfect shape. Less inclined to burst than many varieties in use; rich, deep green color; tender and of fine quality. Pkt., 10z; oz., 30c; $1 / 4$ lb., 90c; lb., $\$ 3.00$.

CHINESE CABBAGE, WONG BOK, ALSO CALLED CELERY CABBAGE-It has wide mid-ribs at the base merging into crisp, tender leares at the top. Has a mild cabbage flavor and is very delicious. It is odorless while being cooked. Excellent for use as a salad or when boiled for greens. The culture for Wong Bok is the same as for late cabbage. When well grown the plants should be blanched by tying loosely with burlap. Set the plants 1 foot apart in the row. Pkt., 10c; 0z., 50c; 1/4 lb., $\$ 1.50$; lb., $\$ 5.00$.

\section{Red Cabbage}

\section{Savoy Cabbage}

AMERICAN DRUMHEAD SAVOY-The largest heading Saroy; the quality and flavor of this crumpled-leaf calbage is very fine. It is sweet and tender. Pkt., 10c; oz., 35c; $1 / 4$ lb., $\$ 1.00 ; 1 b ., \$ 3.50$.

\section{Early Varieties}

COPENHAGEN MARKET-A new and early variety producing fine heads weighing 10 to 12 pounds, which are very solid and of excellent quality. It is the largest of the early round varieties. Pkt., $10 \mathrm{c} ; 0 \mathrm{z} ., 35 \mathrm{c} ; \mathrm{I} / 4 \mathrm{lb}$, $\$ 1.00 ; 1 \mathrm{~b} ., \$ 3.50$.

EARLY JERSEY WAKEFIELD-One of the best and most popular early varieties. Forms round, pointed heads of good size. Is very hardy and on account of its thirk outside leaves is able to resist cold and other unfavorable ronditions to a great extent. Pkt., 10c; oz., $30 \mathrm{c} ; \mathrm{r} / \mathrm{4}$ lb., $90 \mathrm{c}$; 1b., $\$ 3.00$.

EARLY WINNIGSTADT-One of the best of the early pointed varieties. It is unsurpassed for its fine texture and its conical-shaped heart is solid, crisp and tender; highly esteemed by growers for its good keeping qualities. Pkt., 10c; 0z., 35c; r/4 1b., \$1.00; 1b., \$3.50.

GOLDEN ACRE-This excellent new variety is the earliest round-headed cabbage. Plants are compact and form solid heads weighing 3 to 5 pounds. Heads should be ready for use 60 to 75 days after transplanting. Pkt., $10 \mathrm{c} ; 0 z ., 60 \mathrm{c} ; \mathrm{I} / 4 \mathrm{lb} ., \$ 1.80 ;$ lb., $\$ 6.00$.
MAMMOTH RED ROCK-Best hard-headed, red variety. Large heads, globular and very deep red on top. Outer leaves greenish. Especially used for pickling. Pkt., 10c; oz., 35c; I/4 lb., \$1.00; lb., $\$ 3.50$.

\section{COLLARDS}

(For cultural directions see page 3 )

A plant bearing a large mass of leaves on the top of a stout stalk. It is a species of cabbage, and the flavor is the same. It bears leaves all through the Winter, and is used especially in the South for cabbage greens.

TRUE GEORGIA-The well known very large variety. Grows from 4 to 5 feet high, and forms a very large, loose head. Leaves are tinged with purple. Pkt., 10c; oz., 20c; 1/4 lb., 50c; lb., $\$ 1.50$.

\section{CORN SALAD}

(For cultural directions see page 3 )

LARGE-LEAVED FETTICUS, OR “LAMB'S LETTUCE” - Hardy little plants, grown for late Fall, Winter and Spring use; they form rosettes of tender, edible leaves, which are used as a substitute for lettuce. Pkt., 10c; oz., 20c; I/4 lb., 60c; lb., $\$ 2.00$. 


\section{HALLAWELL SEED CO. VEGETABLE SEEDS SAN FRANCISCO, CALIF.}

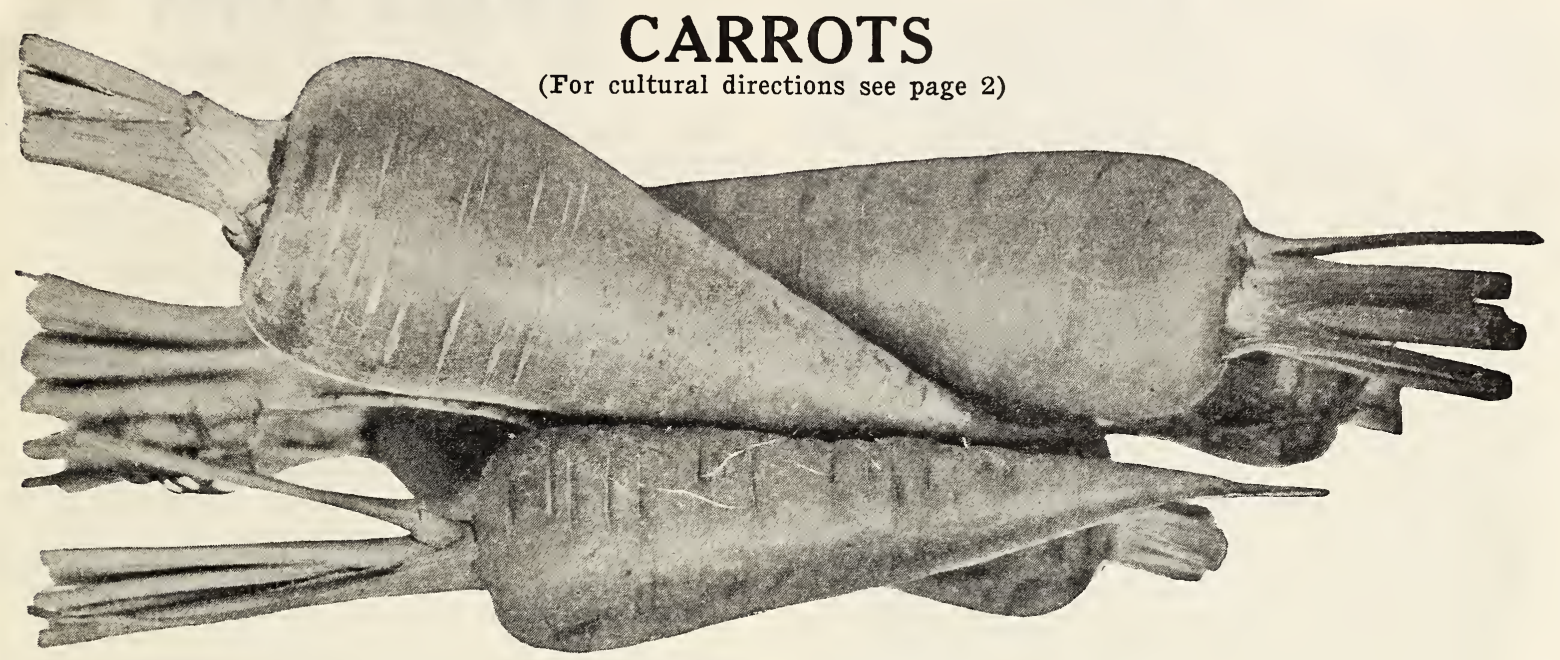

Danvers Half Long Carrots

DANVERS HALF LONG-A rich orange red sort, growing about 8 inches long. Largely used for table use and stock raising as well. Very productive; flesh sweet and crisp. Pkt., 10c; 0z., 20c; I/4 lb., 45c; lb., \$1.25.

EARLY SCARLET HORN-This is a favorite for early crop, but not large; sold extensively in the markets bunched. The tops are small; roots top-shaped, stumprooted, therefore easily pulled. Grows well in shallow soil. Color is a deep orange; flesh fine-grained. Pkt., 10c; 0z., 20c; r/4 1b., 45c; lb., \$1.25.

OXHEART OR GUERANDE-A popular short, thick variety about $4 \mathrm{I} / 2$ inches long and $3 \frac{1}{2}$ inches thick at the shoulder. A good variety for heavy or stiff soils; heavy cropper. Pkt., 10c; 0z., 20c; I/4 lb., 45c; lb., \$1.25.
FRENCH FORCING-A small, round, reddish orange variety; crisp and sweet; the best of this class. Pkt., 10c; 0z., 20c; I/4 lb., 50c; lb., \$1.50.

WHITE MASTODON-Very large white root, a heavy cropper. The best variety for stock. Pkt., 10c; 0z., 20c; I/4 Ib., 35c; lb., $\$ 1.00$.

IMPROVED LONG ORANGE-The best long carrot in cultivation; especially recommended for market gardeners and field culture. It is a good reliable variety, always depended upon for its uniformity and large crop. Grows best in light, rich, well-dug soil. Pkt., 10c; oz., 20c; I/4 lb., 45c; lb., $\$ 1.25$.

CHANTENAY OR MODEL-An excellent early, half long stump-rooted variety; 5 or 6 inches long and about 3 inches thick at the shoulder. Bright orange scarlet, heavy cropper. Pkt., 10c; 0z., 20c; I/4 lb., 45c; lb., \$1.25.

\section{CAULIFLOWER}

(For cultural directions see page 2)

EARLY SNOWBALL-The best and most popular early variety grown. There is a vast difference in the strains of this variety offered, but what we offer is the best imported stock. Those who have had trouble with cauliflower should try this Snowball. It will make uniformly fine heađs, even under adverse conditions. Pkt., 25c; I/4 oz., 90c; oz., \$2.75; I/4 lb., $\$ 8.50$.

CALIFORNIA WONDER-A late variety, forming good, large, solid heads during the Winter. This variety has given great satisfaction in California wherever tried. Pkt., 15c; I/4 0z., 50c; 0z., \$1.50; $\mathrm{I} / 4 \mathrm{lb}$., $\$ 5.00$.

VEITCH'S AUTUMN GIANT--The most popular of all the late varieties. The heads are pure white, large, firm and compact; being well protected by the foliage, they remain fit for use for a long time. Pkt., $10 \mathrm{c} ; \mathrm{r} / 4$ 0z., $25 \mathrm{c} ; 0 \mathrm{z} ., 65 \mathrm{c} ; \mathrm{I} / 4$ lb., $\$ 2.00$.

DRYWEATHER - This fine variety is especially adapted for localities subjected to long, dry seasons. It is a very sure header, second early, and produces large, pure white heads of delicious flavor. Pkt., 25c; $1 / 4$ oz., 90c; oz., $\$ 2.75$; I/4 lb., $\$ 8.50$.

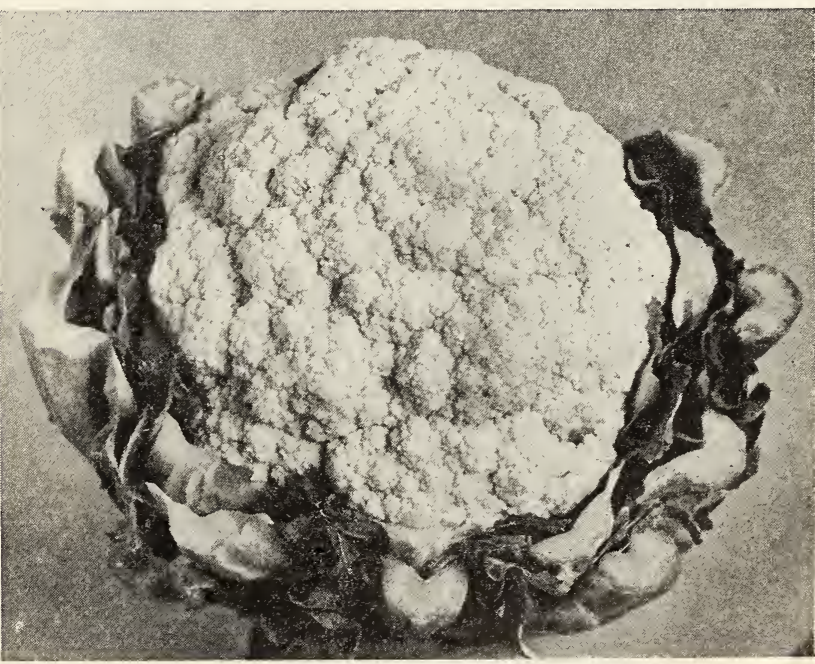

Extra Early Snowball Cauliflower 


\section{hallawell SEEd co. VEGETABLE SEEDS san Francisco, calif.}

\section{CELERY}

(For cultural directions see page 2)

GOLDEN PLUME-A large early Celery of smperfine quality and appearance. Large heary stalks with a full, solid heart of golden yellow, easy to blanch, a good keeper and alwars (risp. Pkt., 20c; oz., \$2.00.

GOLDEN SELF-BLANCHING OR PARIS GOLDEN This fine variety is probably the most extensively grown of all the Celeries. Very heavy and compact in growth, the stalks being thick, crisp and brittle, while the hearts are large and solid, blanching a beantiful golden vellow color; tlavor rich and delightful. Select California grown strain. Pkt., 10c; oz., 80c; I/4 lb. $\$ 2 . \pm 0 ; 1 b ., \$ 8.00$.

WHITE PLUME PERFECTED-A most delicions, cris $p$ and nutty variety; absolutely solid and free from stringiness; stalk and portions of inner leaves are white; onter leaves are variegated, presenting a nice aplearance. Pkt., 10c; 0z., 35c; 1/4 1b., \$1.00; 1b., \$3.50.

GIANT PASCAL_-Of vigorous, sturdy growth, making immensely heavy stalks and large, heavy liearts, all remaining de'p green mntil blanched by earthing np. Pkt., 10c; 0z., 35c; I/4 lb., \$1.00; lb., \$3.5்.

\section{CELERIAC \\ Turnip-Rooted Celery \\ (For cultural directions see page 2)}

LARGE SMOOTH PRAGUE-This is an improved form of the Turnip-Rooted Celery. Roots large, round and smooth, and free from side roots; a profitable variety for market gardeners. Pkt., 10c; oz., 25c; 1/4 lb., 75c.

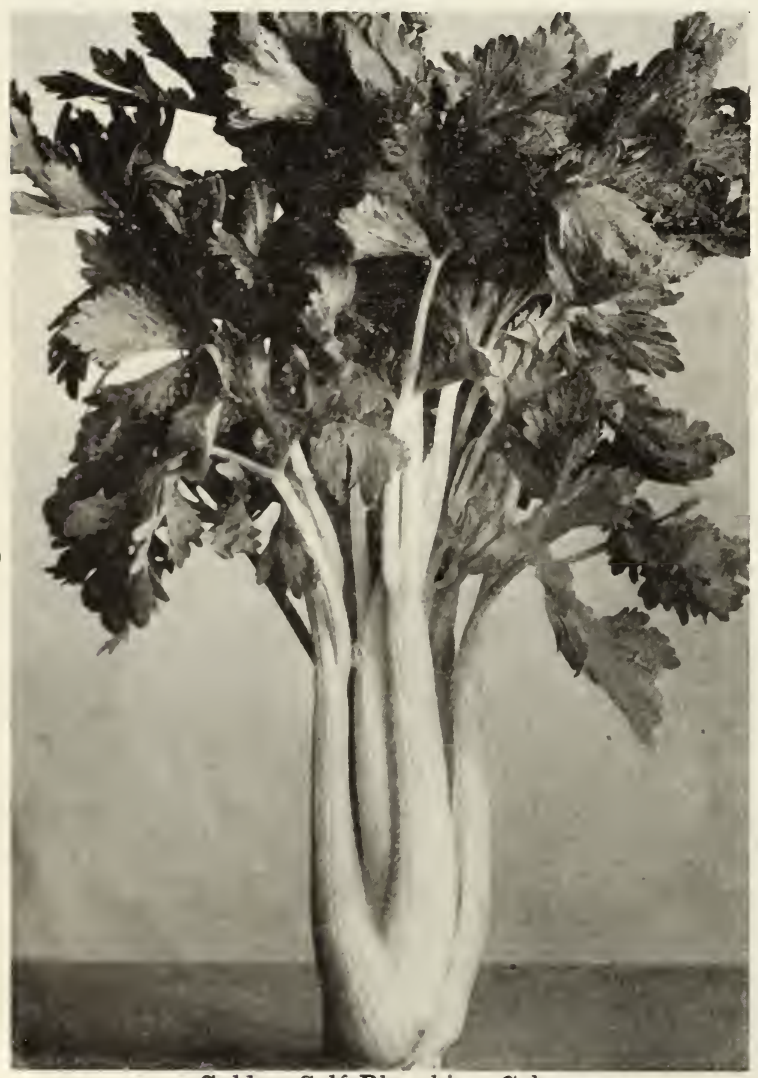

Golden Self-Blanching Celery

\section{SWEET CORN}

(For cultural directions see page 3 )

We prepay charges on all seeds in packets, ounces, pound and 10-pound lots. See special free delivery offer on inside of front cover.

\section{Best Sweet Corn Grown}

BLACK MEXICAN-Medium early; the kernels are black when ripe and white when green; ears 8 inches long, well filled and exceptionally sweet. Pkt., 10c; lb., 35c; $10 \mathrm{lbs} ., \$ 3.00$.

COUNTRY GENTLEMAN, OR SHOE PEG-We recommend this (main crop) variety for your kitchen garden. The great merit of the Country Gentleman Corn is its delicious sweetness, retaining its delicate tenderness even when a little old. Milky kernels, that are pearly white and plump. Pkt., 10c; 1b., 35c; 10 lbs., \$3.00.

EARLY MAMMOTH, OR ALAMEDA SUGAR-A vigorous, large, early variety of handsome appearance and sweet flavor, especially fine for the market grower. Pkt., 10c; lb., 35c; 10 lbs., $\$ 3.00$.

GOLDEN BANTAM-A very early variety. The ears are but medium size, but are thickly set with delicious yellow kernels. The quality of this variety is superb, and it has become a general favorite early sweet corn with all who have tried it. Pkt., 10c; lb., 35c; 10 lbs., $\$ 3.00$.

GOLDEN CREAM-An extra early sugar corn, similar to the Country Gentleman except in color, which is a rich cream changing to golden yellow when cooked. Fine quality, being very sweet and tender. Pkt., 10c; lb., 35c., 10 lbs., $\$ 3.00$.

HOWLING MOB-One of the best flavored and most tender of all the second-early white sweet corns. The ears measure from 7 to 9 inches in length. They are closely set with 12 or 14 rows of large, pearly white grains. Pkt., 10c; lb., 35c; 10 lbs., $\$ 3.00$.

OREGON EVERGREEN-Very sweet and fine; kernels are white; ears large; earlier than Stowell's Evergreen. Pkt., 10c; lb., 35c; 10 lbs., $\$ 3.00$.

STOWELL'S EVERGREEN-The best of all the late sorts, producing large, handsome ears filled with plump, deep, large, white kernels. Quality and flavor surpassingly fine and sugary. Pkt., 10c; lb., 35c; 10 lbs., $\$ 3.00$.

\section{Field Varieties}

Field Corn should be planted in hills 4 feet apart each way; use 10 pounds to the acre.

LEAMING-An early tall-growing variety. Kernels are long and deep golden yellow, stocks are leafy and make excellent forder. Lb., 20c; 10 lbs., $\$ 1.00$.

EARLY EIGHT-ROWED CANADA, also known as the Yellow Flint-A rapid growing, early variety, and for this reason largely used for replanting. Very valuable where the seasons are short. Lb., 20c; $10 \mathrm{lbs}$., $\$ 1.00$.

POP CORN, WHITE RICE-Very prolific; ears short; kernels long, resenibling rice in shape; color, white. Pkt., 10c; 1b., 30c; 10 lbs., $\$ 2.50$. 


\section{CUCUMBERS}

(For cultural directions see page 3)

ARLINGTON WHITE SPINE-A rich, dark green variety, turning white when ripened. The fruit is about seven inches long when in marketable condition and very straight and even in shape. Is early, and good for forcing and out-of-door culture. Pkt., 10c; 0z., 20c; I/4 lb., 45 c; lb., $\$ 1.25$.

EARLY CLUSTER-A short, prickly variety; usually grows in clusters. Is a prolific bearer, and one of the earliest sorts. Flavor excellent. Pkt., 10c; 0z., 20c; I/4 lb., 45c; lb., \$1.25.

EXTRA EARIY GREEN PROLIFIC or BOSTON PICKLING-A very prolific variety, used principally for pickles. Fruit medium sized, bright green, very even and symmetrical. Pkt., 10c; 0z., 20c; I/4 lb., 45c; lb., $\$ 1.25$.

GHERKIN-A very small prickly variety, very tender and sweet when pickled young. Used for pickles only. Pkt., 10c; 0z., 25c; I/4 ib., 75c.

IMPROVED TELEGRAPH-An English cucumber, for frames or forcing under glass; rich dark green. The finest type of Telegraph cucumber, quick in growth and very prolific. Pkt., 25 c.

JAPANESE CLIMBING-The fruits are long and thick and exceedingly tender. Fine for growing on trellises. Pkt., 10c; 0z., 20c; I/4 lb., 50c; lb., \$1.50.

KLONDYKE-A desirable early dark green variety of White Spine cucumber. Very prolific and a fine shipping sort. Pkt., 10c; oz., 20c; I/4 lb., 50c; lb., \$1.50.

LEMON-A very easily grown variety for the home garden. It is lemon shaped. It is ready to eat when it begins to turn yelowish green. Pkt., 10c; oz., 25c; $\mathrm{I} / 4 \mathrm{lb}$., $85 \mathrm{c}$.

LONG GREEN-The best known and most popular variety for general use. The mature fruit is almost 12 inches long. The skin is of a deep green, and the flesh is solid, crisp and of fine quality. Pkt., 10c; oz., 20c; I/4 lb., $65 c ; 1 b ., \$ 2.00$.

\section{ENDIVE}

(For cultural directions see page 3 )

GREEN CURLED-The hardiest variety grown, the midrib is wide and whitish, beautifully curled, tender and crisp; much used for garnishing. Pkt., 10c; oz., 20c; I/4 lb., 50c; lb., \$1.50.

BROAD-LEAVED BATAVIAN (Escarolle)-Leaves broad and thick and nearly plain; chiefly used in stews and soups. Pkt., 10c; oz., 20c; I/4 lb., 50c; lb., $\$ 1.50$.

\section{KOHL RABI}

(For cultural directions see page 4 )

EARLY WHITE VIENNA-Pkt., 10c; oz., 30c; I/4 lb., 90c. EARLY PURPLE VIENNA-Pkt., 10c; 0z., 30c; I/4 lb., 90c.

\section{DANDELION}

(For cultural directions see page 3 )

IMPROVED LARGE-LEAVED-The largest leared and best cutting variety. Pkt., $10 \mathrm{c}$.

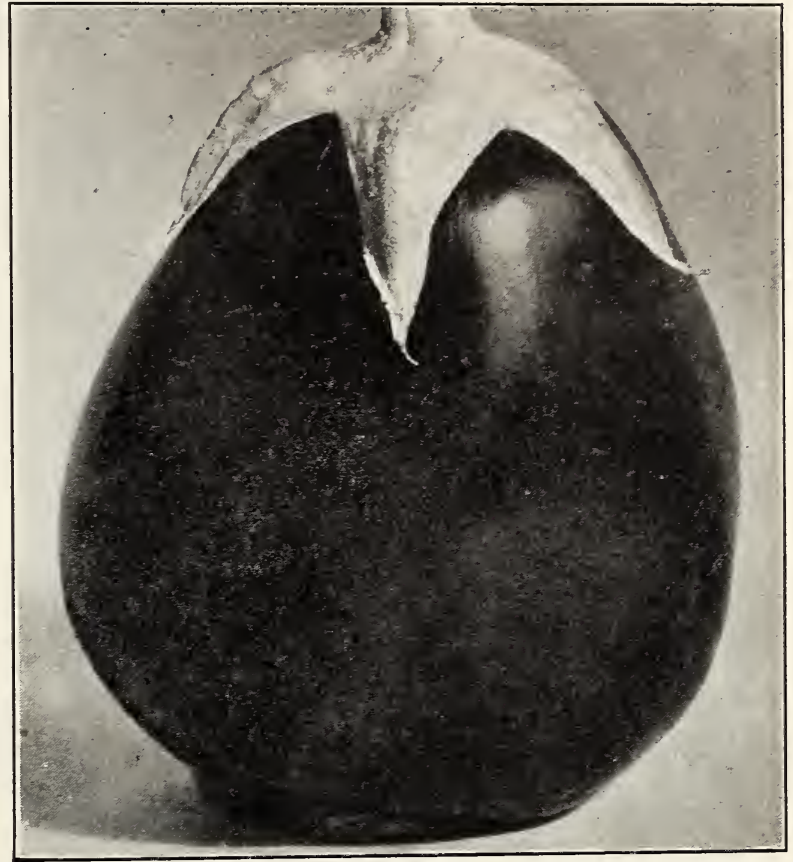

Improved New York Egg Plant

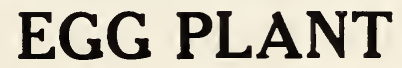

(For cultural directions see page 3 )

IMPROVED NEW YORK-The most popular main crop variety. The fruit is large, very solid and of a rich shining deep purple color. Pkt., 10c; oz., 50c; I/4 lb., $\$ 1.50 ;$ lb., $\$ 5.00$.

BLACK BEAUTY-An early variety. The fruit is broad and thick and a purplish black color. Pkt., $10 \mathrm{c}$; 0z., $50 \mathrm{c}$; I $/ 4$ lb., $\$ 1.50 ;$ lb., $\$ 5.00$.

\section{KALE OR BORECOLE}

(For cultural directions see page 4)

TALL GREEN CURLED SCOTCH - Finely cut leaves, height $2 \mathrm{r} / 2$ feet. Pkt., 10c; oz., 20c; I/4 lb., 50c; lb., $\$ 1.50$.

JERSEY or THOUSAND HEADED-A strong growing sort with smooth leaves, often 6 to 8 feet high; grown largely for chicken feed. Pkt., 10c; 0z., 20c; I/4 lb., 45c; lb., $\$ 1.25$.

\section{LEEK}

(For cultural directions see page 4)

LARGE AMERICAN FIAG-The favorite variety. Pkt., 10 c; oz., 25c; I/4 lb., 75c; lb., $\$ 2.50$.

GIANT MUSSELBURGH-Thick, long, sweet stalks. Pkt., 10 c; 0z., 25c; I/4 lb., 75c; lb., $\$ 2.50$.

\section{MUSHROOM SPAWN}

(For cultural directions see page 4)

IAMBERT'S PURE CULTURE-Bricks, 40c each, postpaid; 5 bricks, $\$ 1.75$, by express. If ordered by mail add postage at zone rates.

Mushroom Culture Pamphlet free on request. 
(For cultural directions see page 4 )

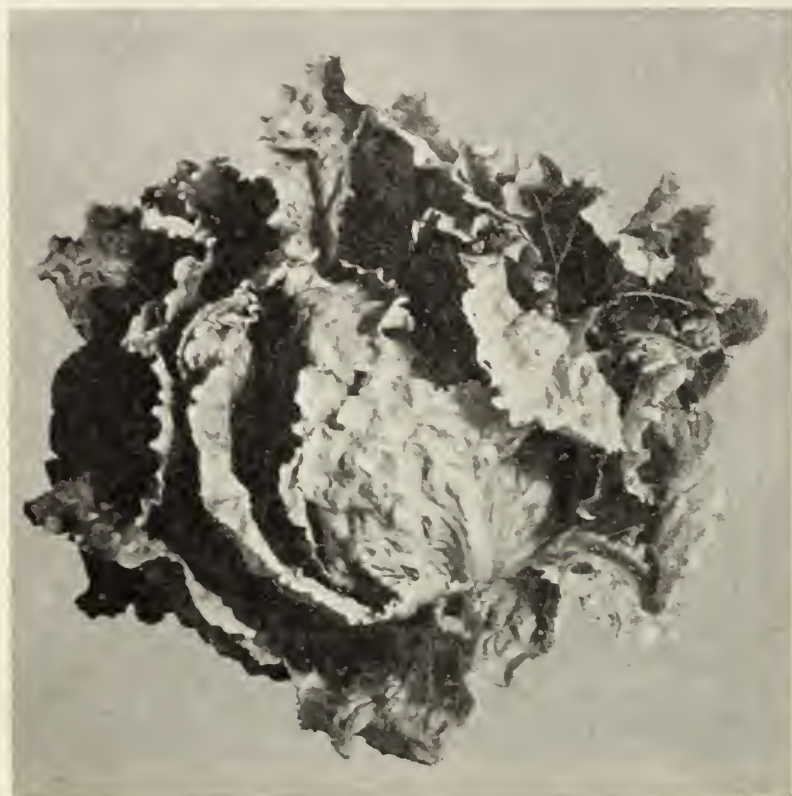

Los Angeles Lettuce

\section{Crisp Head Varieties}

These make a quick growth and form fine large heads which are always crisp, mild and extremely juicy. They withstand the heat better than any other trpe of lettuce.

HANSON-The heads are solicl and grow to a good size The leaves. which are of a light green color, tightly overlap each other; very crisp and brittle. Pkt., 10c; oz., 20c; $1 / 4$ lb., 65c; 1b., $\$ 2.00$.

ICEBERG-Large solid heads; light green, slightly tinged with brown; very tender and crisp. Pkt., 10c; oz., 20c; $\mathrm{I} / 4 \mathrm{lb}$., $65 \mathrm{c} ; 1 \mathrm{~b} ., \$ 2.00$.

LOS ANGELES - A large crisp tight-heading variety; light-green curly leaves. There is no waste in preparing as all the leaves can be userl. The heads are large and of fine quality. We rerommend this variety above all others. Pkt., 10c; 0z., 25c; 1/4 lb., 85c; lb., \$2.50.

\section{Loose Leaf Varieties}

These rlo not form heads but large plants of lonse leaves which are quite brittle and tender.

EARLY CURLED SIMPSON-Forms a close compart mass of leaves; matures very early. Pkt., 10c; oz., 20c; I/4 lb., 50c; lb., $\$ 1.50$.

EARLY PRIZEHEAD-l, waves are brownish rell, very curly and of fine flavor. Makes a rompact bunch. Pkt., $10 c ; 0 z ., 20 c ; x / 4$ lb., 50c; lb., $\$ 1.50$.

CHICKEN LETTUCE-Sends up a stont stalk 3 to 4 feet high, loaded with leaves; for poultry and rabbits. Pkt., $10 \mathrm{c} ; 0 z ., 20 \mathrm{c} ; \mathrm{x} / 4 \mathrm{lb} ., 50 \mathrm{c} ; 1 \mathrm{~b} ., \$ 1.50$.

\section{Romaine, Cos or Celery Lettuce}

This type of lettuce forms long upright loose folding heads and the inner leaves bleach white. It is usually preferable to tie up the heads to assist bleaching.

PARIS WHITE COS-Tery crisp and sweet. Pkt., 10c; oz., 20c; $1 / 4 \mathrm{lb}$., $65 \mathrm{c} ; \mathrm{lb}$., $\$ 2.00$.

\section{Cabbage or Butterhead Varieties}

Tight heading varicties. The leaves making the heads are closely folded together and the imner portion is blanched to a clear white or a rich buttery yellow.

BIG BOSTON-Very large, tender heads; leaves are light green with a slight tinge of brown on margins of the outer leaves. Pkt., 10c; oz., 20c; $1 / 4$ lb., 65c; lb., $\$ 2.00$.

CALIFORNIA CREAM BUTTER OR ROYAL SUMMER CABBAGE - A popular large heading variety for Antumm and Winter use. The leaves are thick, dark green tinged with brown and spotted. The interior of the head is a rich golden yellow; quality very fine. Pkt., 10c; oz., 20c; $1 / 4$ lb., 50c; lb., $\$ 1.50$.

MAY KING-A very early solid head variety of the best quality. The outer leaves are green tinged with brown, while the inside is golden yellow. Pkt., 10c; oz., 20c; I/4 lb., 60c; lb., $\$ 1.75$.

MIGNONETTE-Heads small, compact; leaves slightly curled; edges tinted brown. Especially suitable for the Hawaiian Islands and other tropical countries. Pkt., $10 \mathrm{c} ; 0 z ., 25 \mathrm{c} ; \mathrm{I} / 4 \mathrm{lb}$., $75 \mathrm{c}$; lb., $\$ 2.50$.

\section{MUSTARD}

CHINESE CURLED -A large broad-leaved variety; leaves are thick with broad white mid-rib. Pkt., 10c; oz., 20c; $\mathrm{I} / 4 \mathrm{lb} ., 35 \mathrm{c} ; \mathrm{lb} ., \$ 1.00$.

SOUTHERN GIANT CURLED-Highly esteemed in the South, where the seed is sown in the Fall, and used in the Spring as a salad. Our stock is the true curled leaf, and produces plants 2 feet high, and of greater breadth, forming enormous bunches. Oz., 10c; $1 / 4 \mathrm{lb}$, $25 \mathrm{c} ;$ lb., 75c.

YELLOW OR WHITE-The old sort, used for salads and fla voring. Oz., $10 \mathrm{c} ; \mathrm{I} / 4 \mathrm{lb}$., $25 \mathrm{c}$; lb., $75 \mathrm{c}$.

\section{CASABA MELONS}

The melons should not be picked until they become quite yellow. Stow away so they do not touch each other, in a cool, dark place. When the rind becomes slightly softened and moist they are ready to eat; some of the melons will keep until February.

GOLDEN BEAUTY - This melon is very similar to Winter I'ineapple except that it has a golden-yellow rind. Pkt., 10c; oz., 20c; 1/4 lb., 60c; lb., \$2.00.

WINTER PINEAPPLE-A large late variety with wrinkled skin and green flesh of a pineapple flavor. Pkt., 10c; 0z., 20c; 1/4 lb., 60c; lb., $\$ 2.00$.

\section{Imported Muskmelon for Forcing}

BLENHEIM ORANGE-A favorite variety; scarlet llesh, grood flavor and very prolific. Pkt., 25c.

WINDSOR CASTLE-Green flesh, oval shape, finely netted, delicious flavor. Pkt., 25c.

Other varieties of Melons-See next page. 


\section{MUSKMELON OR CANTALOUPE}

(For cultural directions see page 4)

DELICIOUS GOLD IINED ROCKY FORD-A grand new muskmelon. It is heavily netted, slightly oval with no ribs. The melon is thick-meated, fine grained and sweet; color, green with a gold margin next to the seed cavity of rery superior quality. Pkt., 10c; oz., 20c; I/4 1b., 65c; 1b., $\$ 2.00$.

EXTRA EARIY HACKENSACK - The melons weigh from 4 to 10 pounds; heavily ribbed and netted; flesh green and rery sweet, of excellent flavor. Pkt., 10c; oz, $20 \mathrm{c} ; \mathrm{I} / 4$ lb., 50c; lb., $\$ 1.50$.

HEARTS OF GOLD-The melons are of medium size, round and distinctly ribbed. The rind and flesh are very firm. The skin is thickly netted and the flesh a rich deep orange color, small seed cavity, of remarkable sweetness and spicy flavor. Pkt., 10c; oz., 20c; I/4 1b., $60 \mathrm{c} ; 1 \mathrm{~b} ., \$ 2.00$.

HONEY DEW-The fruit of this melon is of medium size, weighing 5 to 6 pounds, light colored smooth skin, thick light green flesh of a delicious honey-like flaror. Pkt., 10c; 0z., 25c; r/4 1b., 75c; 1b., \$2.25.
PERSIAN-A large globular melon, heavily netted without ribs; orange flesh of delicious flavor; a good keeper. Pkt., 10c; 0z., 50c; I/4 lb., \$1.50; lb., $\$ 5.00$.

POLLOCK 10-25 - A new melon of the solid netted type of slightly oval shape and 5 to 6 inches long. The seed cavity is very small with thick salmon tinted flesh shading to green near the rind, of delicious flavor. A splendid keeper and prolific yielder. Pkt., 10c; oz., 20c; $\mathrm{I} / 4 \mathrm{lb}, 60 \mathrm{c} ; \mathrm{lb} ., \$ 1.75$.

ROCKY FORD NUTMEA OR NETTED GEM-This is the finest muskmelon or cantaloupe that comes in the Sau Francisco markets. It is slightly oval and slightly ribbed with netted skin. Has thick dark green flesh of delicate flavor, with a small seed cavity. Pkt., 10c; oz., $20 \mathrm{c} ; \mathrm{I} / 4 \mathrm{lb} ., 50 \mathrm{c} ; \mathrm{lb} ., \$ 1.50$.

TIP TOP-The melons are of medium size and nearly round, well ribbed and slightly netted over a light green skin. The flesh is quite thick and bright salmon in color. Very richly flarored. Pkt., 10c; 0z., 20c; I/4 lb., $60 \mathrm{c} ; \mathrm{lb} ., \$ 1.75$.

Casaba and Forcing Melons-See preceding page.

\section{WATERMELONS}

(For cultural directions see page 4)

FLORIDA FAVORITE-A splendid melon of rery large size and excellent quality. Fruit long, dark green, mottled and striped with lighter shade; rind thin but firm. Flesh bright deep red; rery sweet and tender. Pkt., 10c; oz., 20c; I/4 lb., 45c; 1b., \$1.25.

GEORGIA RATTIESNAKE OR GYPSY-Fruit very long, of light green color, distinctly striped and mottled with a darker shade. Flesh bright scarlet; very sweet and tender. Pkt., 10c; 0z., 20c; I/4 lb., 45c; lb., \$1.25.

KLONDYKE-A great farorite of recent introduction. Oblong, dark rich green, flesh bright red, very crisp and sweet. Pkt., 10c; oz., 25c; I/4 lb., 75c; 1b., $\$ 2.50$.
KLECKLEY SWEET OR MONTE CRISTO-A very desirable melon for home use or nearby markets. Fruit of medium to large size, oblong, dark green. Flesh bright red and very sweet. Pkt., $10 \mathrm{c} ;$ oz., 20c; I/4 1b., 45c; lb., $\$ 1.25$.

TOM WATSON-A very large, long melon with dark green skin. Flesh bright red; rery sweet and tender. Rind thin but tough, making it a good shipping sort. Pkt., $10 \mathrm{c} ;$ oz., $20 \mathrm{c} ; \mathrm{I} / 4$ lb., $45 \mathrm{c}$; lb., $\$ 1.25$.

ANGEIINO - A round deep green melon, rind very thin, flesh deep red and of fine flavor; a good shipper. Pkt., 10c; oz., 20c; I/4 1b., 50c; 1b., $\$ 1.50$.

B L A C K SEEDED CHILIAN - A fine melon for the home garden; of medium size, nearly round, black seed and red flesh of excellent flavor. Pkt., 10c; oz., 20c; r/4 lb., 45c; 1b., $\$ 1.25$.

CHILIAN-A very desirable melon for the hom e garden; of medium size, nearly round; skin is deep green, faintly mottled and striped; flesh is bright red, fine grained and very sweet. Pkt., 10c; oz., 20c; I/4 1b., 45c; lb., $\$ 1.25$.

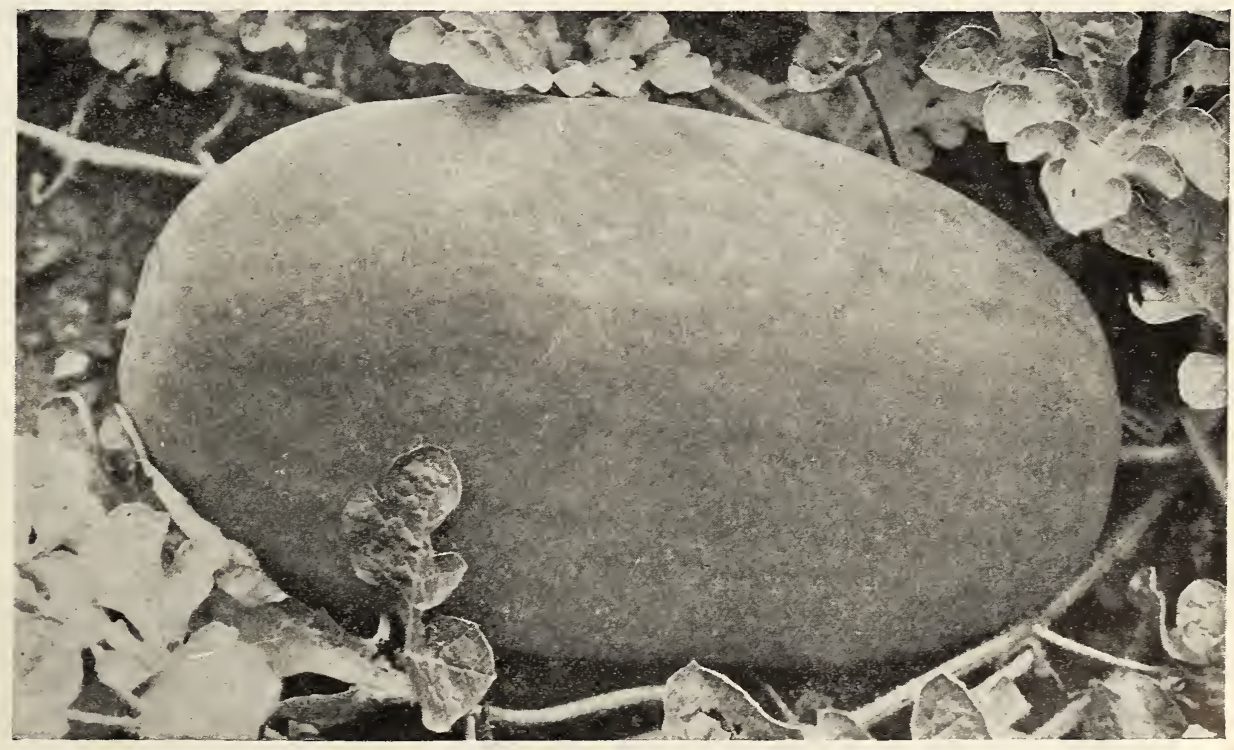

Tom Watson Watermelon 


\section{HaLLAWELL SEED co. VEGETABLE SEEDS SAN Francisco, Calif.}

\section{ONIONS}

(For cultural directions see page 5)

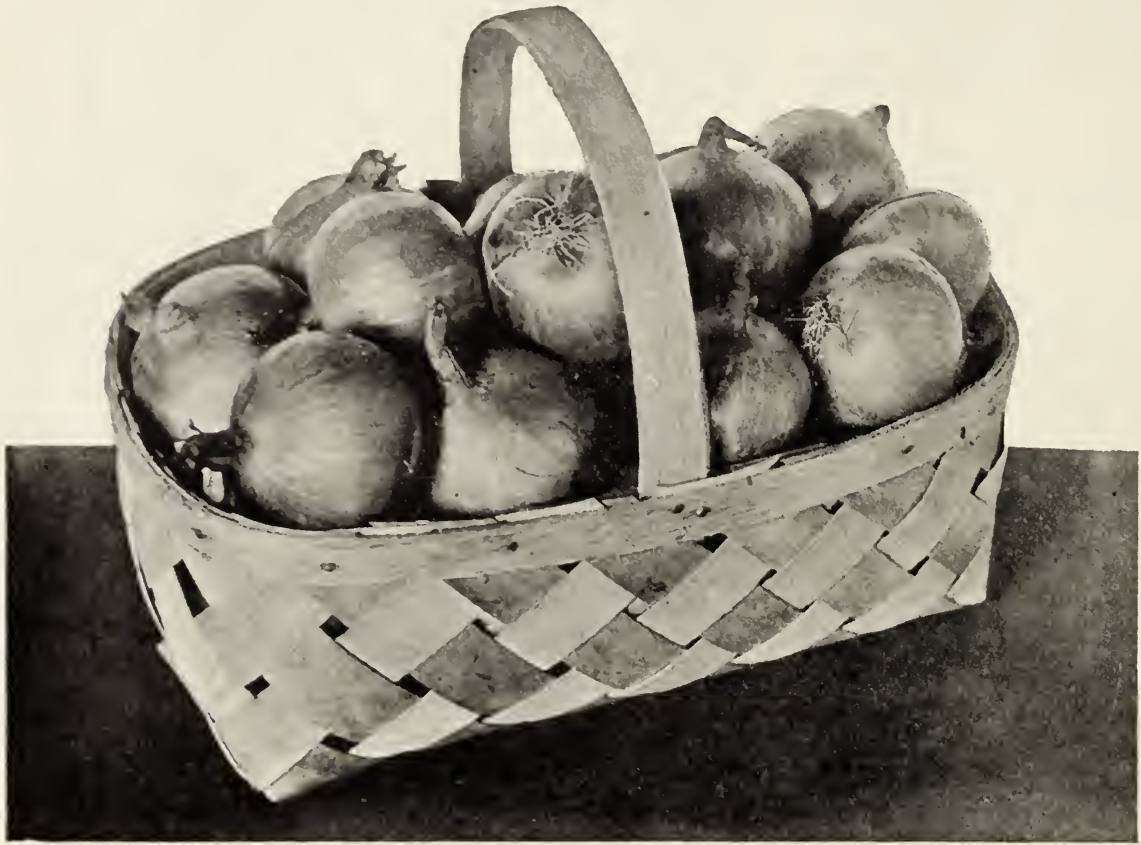

SOUTHPORT RED GLOBE-

A large deep-red glcibeshaped variety, flesh fine grain, mild and tender. good keeper. Pkt., 10c; oz., 30c; I/4 lb., \$1.00; lb., $\$ 3.00$.

SOUTHPORT WHITE GLOBE - A large globeshaped sort, pure white color, mild flavor and fine keeper. Pkt., 10c; oz., 40c; I $/ 4$ lb., $\$ 1.25$; lb., $\$ 4.00$.

SOUTHPORT YELLOW GLOBE- Fle sh fine grained, mild and tender; the bulbs are globe-shaped and a pale vellow color; good keeper. Pkt., 10c; oz., $30 c ; 1 / 4$ lb., 90c; lb., $\$ 2.75$.

\section{EARLY SWEET SPANISH-}

A very large, mild, yellow, globe-shaped onion. One of the best for home garden; also an early market Spanish type. Pkt., 10c; oz., $40 \mathrm{c}$; $1 / 4$ lb., $\$ 1.25$; lb., $\$ 4.00$.

Yellow Flat Danvers Onion

AILSA CRAIG-A very large pale yellow variety similar to Prizetaker, but much larger and more globular in form. Very productive and of fine mild flavor. Pkt., 10c; oz., 35c; 1/4 lb., $\$ 1.00 ;$ lb., $\$ 3.50$.

AUSTRALIAN BROWN-Extra long keeper and sure cropper. Early and very hardy. The skin is a rich brown, solid white flesh, crisp and of sweet mild flavor. Sllould be planted early on low, wet ground to get large bulbs. Pkt., 10c; oz., 20c; I/4 lb., 60c; lb., $\$ 2.00$.

CRYSTAL WHITE WAX-The clear white Bermuda onion, seen in our market early in spring, is this variety. Medium sized and of a very mild, sweet flavor. Pkt., 10c; oz., 75c; 1/4 lb., $\$ 2.50$; lb., $\$ 7.50$.

PRIZETAKER - A fine onion of large size and nearly globular in form. Skin is yellowish brown; flesh white and nild. A heavy cropper and a fairly good keeper. Pkt., 10 c; oz., 25c; I/4 lb., 75c; lb., \$2.50.

\section{RED BOTTLE SHAPED or LONG ITALIAN RED-A} variety used in California markets. It is light red and is long and narrow. Early and mild in flavor. Excellent for slicing. Pkt., 10c; oz., 40c; I/4 lb., \$1.25; lb., \$4.00.

RED WETHERSFIELD-This is the standard red variety. Large size, form flat but thick; skin purplish red; flesh firm and mild. Heavy eropper. Pkt., 10c; 0z., 25c; I/4 lb., 75c; lb., $\$ 2.50$.
WHITE BERMUDA-A very early flat variety; skin a yellow straw color; flesh very mild. Used largely for planting in the Fall. Pkt., 10c; 0z., 50c; 1/4 1b., \$1.50; lb., $\$ 5.00$.

WHITE PORTUGAL OR SILVER SKIN-The favorite white variety, of medium size with clear white skin and mild flavor. It is an excellent keeper and also a good variety for growing for pickles. Pkt., 10c; 0z., 35c; I $/ 4$ lb., $\$ 1.00 ; 1$ lb., $\$ 3.50$.

YELLOW FLAT DANVERS-The best yellow flat onion. Very mild and fairly early. Color, bright orange yellow; flesh, white and firm; fine keeper and of good size. Pkt., 10c; 0z., 20c; I/4 lb., 60c; lb., \$2.00.

YELLOW GLOBE DANVERS-A popular sort for home and market use. It is of perfectly globular shape, being almost round with a very small neck. The color of the skin is a rich orange yellow; of large size; remarkably solid; a heavy cropper. Pkt., 10c; oz., 25c; 1/4 1b., 75c; 1b., $\$ 2.50$.

Onion sets for young onions. Plant 2 inches deep and 2 inches apart in drills which should be 12 inches apart. 1 pound will plant about a 50 foot row.

YELLOW ONION SETS-Lb., 20c, postpaid.

GARLIC-Prices on application. 


\section{PEAS}

(For cultural directions see page 5)

We prepay charges anywhere within the fourth parcel post zone on all seeds in packets, pound and 10 -pound lots.

\section{Early Varieties}

ALASKA, OR EARLIEST OF ALI-A very early tall variety, vines 2 to $2 I / 2$ feet, with smooth, small peas, green seeded, of good quality and short, well-filled pods. Popular sort with canners and market gardeners; will not rot in cold, wet soil. Pkt., 10c; lb., 35c; $10 \mathrm{lbs}$., $\$ 3.00$.

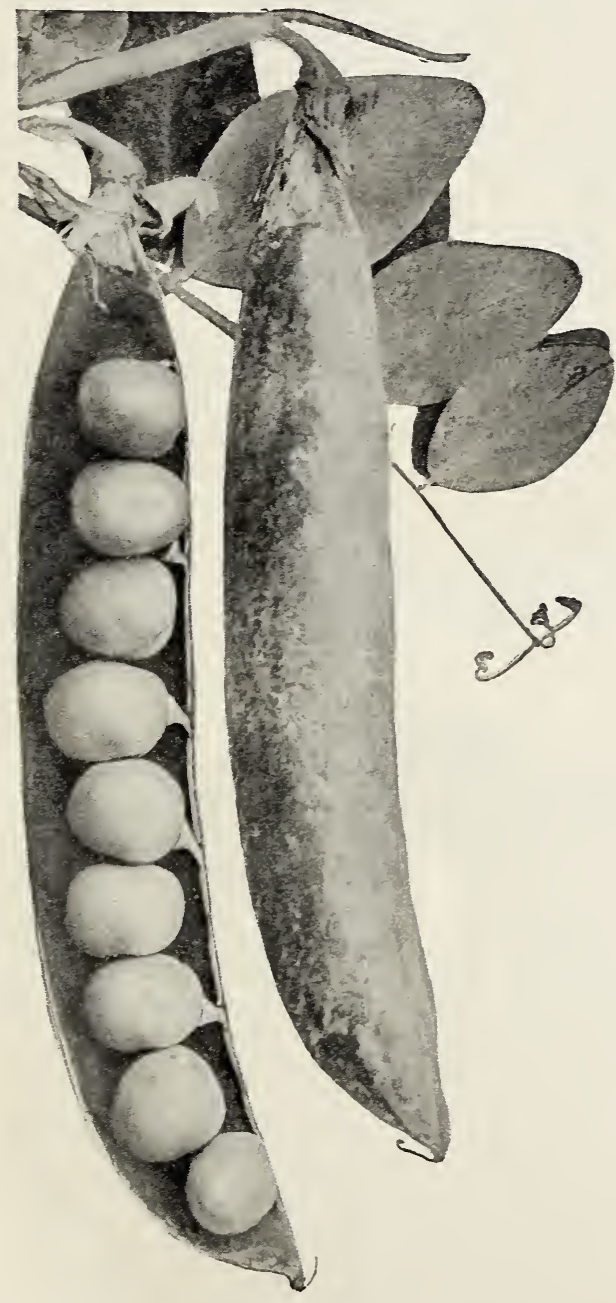

Telephone Peas

AMERICAN WONDER-An extra early sort and a heavy cropper, ready to pick in 45 to 50 days from time of planting. The rines require no support as they only grow 12 to 15 inches high. Pkt., 10c; lb., 35c; 10 lbs., $\$ 3.00$.

BLUE BANTAM-An early semi-dwarf variety bearing very long pods of a deep green color; very prolific. Pkt., 10c; 1b., 35c; 10 lbs., $\$ 3.00$.
GRADUS OR PROSPERITY - A very early large podded sort, growing 3 to $31 / 2$ feet high. Peas are large, of fine quality and light green in color. Pkt., 10c; lb., 35c; 10 lbs., $\$ 3.00$.

LAXTON'S PROGRESS-The largest podded of any extra early dwarf variety. Pods pointed, dark green, well filled and very prolific. Pkt., 10; lb., 35c; 10 lbs., $\$ 3.00$.

IITTLE MARVEL-A prolific dwarf variety about 15 inches high; pods average $2 \mathrm{I} / 4$ inches in length, well filled with 6 or 7 large peas of excellent flavor. Pkt., $10 \mathrm{c} ; \mathrm{lb} ., 35 \mathrm{c} ; 10 \mathrm{lbs} ., \$ 3.00$.

THOMAS LAXTON-A fine early tall variety similar to Gradus, but more hardy and not so early. It is also darker in color and has large blunt pods that are well filled with peas of finest quality. Pkt., 10c; lb., 35c; 10 lbs., $\$ 3.00$.

\section{Later Varieties}

CARTER'S DAISY, OR DWARF TELEPHONE-A dwarf variety producing large pods like Telephone; very prolific and of fine quality; height 18 inches. Pkt., 10c; lb., 35c; 10 lbs., $\$ 3.00$

MELTING SUGAR OR EDIBLE POD-A prolific variety bearing brittle pods, which are cut or broken and cooked like beans. The pods are very large, broad and extremely tender; finely flavored. Pkt., 10c; lb., 35c; 10 lbs., $\$ 3.00$.

STRATAGEM-A rery strong grower, very prolific, with dark green pods of good size and well filled. Vines grow about $2 \mathrm{I} / 2$ feet high. Pkt., 10c; lb., 35c; $10 \mathrm{lbs}$., $\$ 3.00$.

TELEPHONE-One of the latest varieties, is tall and vigorous, with enormous pods, bearing large, wrinkled peas of remarkable fine quality; a popular home garden and market varietr. Pkt., 10c; lb., 35c; 10 lbs., $\$ 3.00$.

YORKSHIRE HERO OR ALAMEDA SUGAR-A semidwarf rariety, growing $2 \mathrm{I} / 2$ feet high. Pods are broad and medium-sized and are well filled with large peas, which remain in good condition for a long time. Pkt., $10 \mathrm{c} ; \mathrm{lb} ., 35 \mathrm{c} ; 10 \mathrm{lbs}$., $\$ 3.00$.

\section{SEED POTATOES}

(For cultural directions see page 5)

\section{(Northern Grown)}

All prices are subject to change

AMERICAN WONDER - Earl 5 , boiling and baking variety.

BRITISH QUEEN-Early, baking variety.

BURBANK (Low Top)-Late keeping variety, good for boiling and baking.

RED ROSE-Early, boiling and baking rariety.

WHITE ROSE-Early baking variety.

Any of the above, $5 \mathrm{lbs}$. for $35 \mathrm{c} ; 10 \mathrm{lbs}$. for $60 \mathrm{c} ; 25 \mathrm{lbs}$. for $\$ 1.25$ f. o. b. San Francisco. If wanted by parcel post add postage. Prices on larger quantities on application. 


\section{OKRA OR GUMBO}

(For cultural directions see page 5)

Highly esteemerl for its roumg seed pods, which are nsed in somps and stews.

PERKIN'S MAMMOTH POD-Pods deep green, ver'T long. slender and slimhtry cormirated; very tender and of crood quality. Pkt., 10c; 0z., 20c; I/4 1b., 35c; lb., \$1.00. WHITE VELVET - l'okls white. long. smooth and tender. Plt., 10c; oz., 20c; I/4 lb., 35c; lb., \$1.00.

\section{PARSLEY}

(For cultural directions see page 5)

Lsed for ganishing dishes of meat, or cooked in soups. A lew plants in the garelen ricld sutficient for a family, provided leaves are cut often and plant not allowed to seed. DOUBLE CURIED - I cmled rariet $y$ very hardy and easy to [rum: Deep rich green. Pkt., 10c; 0z., 20c; I/4 lb., $45 \mathrm{c}$; lb., \$1.25.

EXTPA TRIPLE CURLED TerT fine curled variety of latk wrcen color. Pht., 10c; oz., 20c; I/4 lb., 45c; lb., $\$ 1.25$.

HAMBURG, OR TURNIP ROOTED-A plain-leaved varicty, forming a long, thi k, edible root. Pkt., 10c; oz., 20c; I/4 lb., $45 \mathrm{c} ; 1 \mathrm{~b} ., \$ 1.25$.

\section{PARSNIPS}

(For cultural directions see page 5)

HOLLOW CROWN-The best and most popular for all purposes. This is a highly improved type, prolm ing mujormly latre roots of stocky form, heary at the shoulder. well rounded. gradually taluring to the base. s) that they are easily dne. anul if sown in properly pulverized soil. the roots will be smooth and fire from wrinkles and side roots. The flesh is white of fine tex-

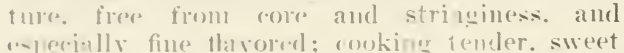
aull ricli. Pkt., 10c; oz., 20c; I/4 lb., $\$ 5 c$; lb., $\$ 1.25$.

\section{PUMPKIN}

(For cultural directions see page 5)

CONNECTICUT FIELD This raristy proruces

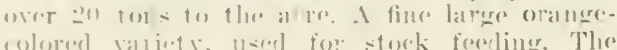
-kin is -moneli and ribberl and the flesh is lorit 1 1. . and - - w.t. Pkt., 10c; 0z., 20c; 1/4 ib., 35c; lb. $\$ 1.00$

LARGE CHEESE OR KENTUCKY FIELD - A

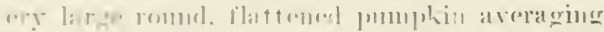

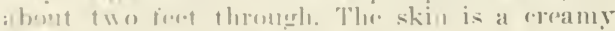
hutf enlor and the flosh vellow and of fire .11alit! Pkt., 10c; 0z., 20z; I/4 lb., 45c; lb., $\$ 1.25$.

MAMMOTH KING OR JUMBO P'mullins of imuntuse siy. weisling from 100 to 1 ton poumels: rlotular in forme and ilatteneel a little at the enul. Salumon-rorauce skin, wry thick orauce. $\$ 1.75$.

SUGAR OR NEW ENGLAND PIE-For making pies this variest ramot bo exerellecl. The pumpkins are roumbl aud suall. but very sweet. fine frained. and of the hest ruality. Pkt., 10c; oz., 20 c; I/4 lb., 45 c; lb., \$1.25.

\section{PEPPERS}

(For cultural directions see page 5)

ANAHEIM CHILI-A large thick-meated "Chili" of recent introduction, being $\tau$ inches or more long, very fleshy, with a slight pungency. Pkt., $10 \mathrm{c} ; 0 z ., 75 \mathrm{c} ; \mathrm{I} / 4 \mathrm{lb}$., $\$ 2.25$.

CHINESE GIANT-The largest of all Sweet Peppers. The flesh is quite thick, very mild and sweet. A blunt, deep red variety. Pkt., 10c; 0z., \$1.00; I/4 lb., \$3.00.

LARGE BELL OR BULL NOSE-A large, early bright red variety of mild flavor; a favorite for pickling and "mangoes" when green. Pkt., 10c; oz., 75c; 1/4 lb., \$2.25.

LONG RED CAYENNE_-Slender pods 3 inches long, jungent. Pkt., 10c; oz., 75c; r/4 lb., \$2.25.

PIMIENTO - A popular variety owing to its lack of pungency; flesh very thick and firm, used largely for canning, as it can be scalded and peeled; also delicious with salads or when stufled. Pkt., $10 \mathrm{c} ; 0 z ., 75 \mathrm{c} ; \mathrm{I} / 4 \mathrm{lb}$. $\$ 2.25$.

RED CHILI - Small, bright red, very pmeent and productive. Pkt., 10c; 0z., 75c; I/4 lb., \$2.25.

RUBY KING - A popular variety of the Bell, or Bull Nose type. The fruit is large, dark green while romg, turuing to bright, glossy red when ripe, and the flavor is mild and sweet. A desirable variety for slicing in salads and for stuffing. Pkt., $10 \mathrm{c} ; 0 z ., 75 \mathrm{c} ; \mathrm{I} / 4 \mathrm{lb}$., $\$ 2.25$.

SWEET MOUNTAIN OR MAMMOTH-Nearly the same as Bull Nose, though usually larger in size and of depner shape; of very mild flavor; fine for "mangoes." Pkt., 10c; 0z., 75c; 1/4 lb., \$2.25.

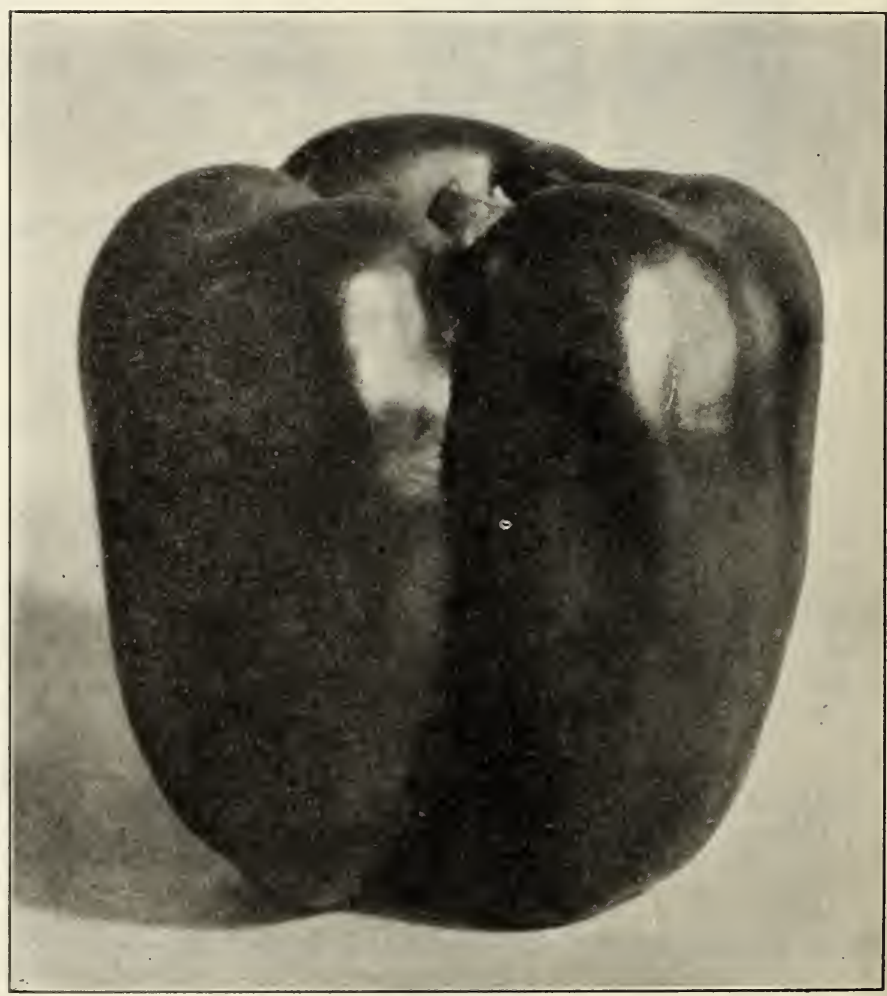

Bell Pepper 


\section{HALLAWELL SEED CO. VEGETABLE SEEDS SAN FRANCISCO, CALIF.}

\section{RADISH}

(For cultural directions see page 6)

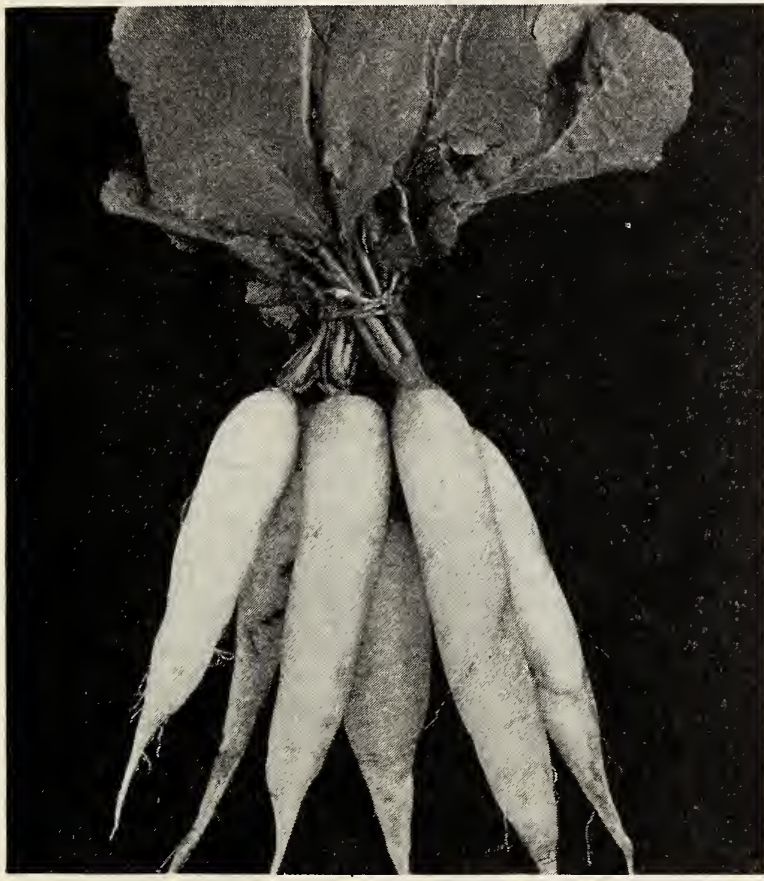

Icicle Radish

\section{Early Spring and Summer Radishes}

CRIMSON GIANT-This variety is suitable for forcing or for early planting out of doors. A round radish of large size and remaining in good condition for a long time. Pkt., 10c; 0z., 20c; 1/4 lb., 45c; lb., \$1.25.

EARLY SCARLET TURNIP-A valuable variety for forcing or outdoor culture. Is a small, turnip-shaped variety; and in color entirely crimson. Pkt., 10c; oz., 20 c; r $/ 4$ lb., $45 c$; lb., $\$ 1.25$.

EARLY SCARLET GLOBE-A popular forcing variety owing to its very thick growth and fine, bight scarlet color. Shape, a trifle oblong. Pkt., 10c; oz., 20c; 1/4 lb., 45 c; 1b., $\$ 1.25$.

SCARLET TURNIP WHITE TIPPED, OR ROSY GEMOne of the most popular varieties. It is globe-shaped, bright rose-carmine with bottom and tip clear white. Very valuable for forcing as well as for the house garden and market. Pkt., 10c; 0z., 20c; I/4 lb., 45c; lb., $\$ 1.25$.

FRENCH BREAKFAST-Scarlet, with white tip; shape nearly oval; good for forcing or Summer sowing. Pkt., 10c; 0z., 20c; I/4 lb., 45c; lb., \$1.25.

HALF LONG, OR OLIVE-SHAPED-The variety most largely used by gardeners in California. It is about 3 inches long with half-stump root and sloping top. Color, carmine. Quick growing and hardy. Remains solid longer than any other variety. Pkt., 10c; oz., 20c; $\mathrm{I} / 4$ lb., $45 \mathrm{c}$; lb., $\$ 1.25$.
ICICLE-A delicious and attractive white variety, about 5 inches long, with sloping top and pointed root. Quick growing, brittle and mild in flavor. Pkt., 10c; oz., 20c; I/4 lb., 45c; lb., $\$ 1.25$.

LONG SCARLET (short top)-The best known and nost popular long variety. Color, bright carmine, and flesh brittle and firm. Abont 6 inches long, the top growing out of the ground about 1 inch. Pkt., 10c; oz., 20c; $\mathrm{I} / 4$ lb., 45c; lb., $\$ 1.25$.

\section{Fall and Winter Radishes}

CHINESE ROSE WINTER (Scarlet China)-One of the very best for Fall and Winter use, and popular with market gardeners; bright rose color; flesh white and firm. of superior quality. Pkt., $10 \mathrm{c} ; 0 z ., 20 \mathrm{c} ; \mathrm{I} / 4 \mathrm{lb}$., 45 c; 1b., $\$ 1.25$.

CALTFORNIA MAMMOTH WHITE WINTER, OR CHINESE WHITE WINTER - Is really a Chinese radish, grown by the Chinese in California; 8 to 12 inches long, and from 2 to 3 inches in diameter; soli? and of good flavor; white in color and exceedingly crisp and tender. Pkt., 10c; 0z., 20c; I/4 lb., 45c; lb., $\$ 1.25$.

ROUND BLACK SPANISH-This is a large, black-skinned rarlish; flesh white and firm, and of a peruliarly rish, delicious flavor. Pkt., 10c; oz., 20c; I/4 lb., 45c; lb., $\$ 1.25$.

LONG BLACK SPANISH-Roots crlindriral 7 to 10 inches long. Pkt., 10c; oz., 20c; I/4 lb., 45c; lb., $\$ 1.25$

LONG WHITE JAPANESE-A Winter variety, growing frequently two feet long and about three inches in diameter. Flesh solid and verv tender; pungent. Pkt., $10 \mathrm{c} ;$ oz., $25 \mathrm{c} ; \mathrm{I} / 4$ lb., $85 \mathrm{c}$; 1b., $\$ 2.50$.

\section{RHUBARB}

(For cultural directions see page 6)

GIANT CRIMSON WINTER-This new variety, which has become very popular and profitable to the grower. is of delicious flavor, extremely hardy, very prolific, and very quick growing. Produces good stems all Winter and Spring. Seed-Pkt., 20c; oz., \$2.50.

For Rhubarb Roots, see page 89

\section{SALSIFY OR VEGETABLE OYSTER}

(For cultural directions see page 6)

MAMMOTH SANDWICH ISLAND-An entirely distinct variety of this regetable. In all respects it far surpasses the old variety. It is considered very nutritious and wholesome when properly cooked; the roots being mashed or made into fritters, it is almost impossible to distinguish them from the oyster fritters. Pkt., 10c; oz., 25c; I/4 lb., 85c; lb., $\$ 2.50$. 


\section{SPINACH}

(For cultural directions see page 6)

BLOOMSDALE SAVOY-Curled and wrinkled, with thick fleshy leaves. Fine for home use and one of the earliest varieties. Oz., 10c; I/4 lb., 20c; Ib., 60c.

LONG STANDING - Leaves large, thick, fleshy and (rumpled. Slow to run to seed. Oz., 10c; I/4 1b., 20c; 1b., 60c.

NEW ZEALAND--A plant with thick, fleshy texture and soft crystalline leaves. Is not like the ordinary spinach in appearance, but it is used in the same way. Sow when the gromnd warms up, soaking the seed in water for 24 hours before sowing. Pkt., 10c; oz., 20c; r/4 lb., $35 \mathrm{c} ; 1 \mathrm{~b} ., \$ 1.00$.

PRICKLY, OR FALL-An exceedingly hardy variety adapted for Fall sowing, commonly used for market in California. Oz., 10c; $1 / 4$ lb., 20c; ib., 60c.

\section{SORREL}

The large leaves, when cooked like spinach, make a very palatable vegetable. In California it grows luxuriantly, spreads rapidly from the root, and becomes an obnoxious weed unless given attention. A confined location in the garden is therefore recommended.

LARGE LEAVED FRENCH-The variety having the largest leaves and therefore the most desirable. Pkt., $10 \mathrm{c} ; 0 \mathrm{z} ., 20 \mathrm{c} ; \mathrm{r} / 4 \mathrm{lb}$., $50 \mathrm{c}$; lb., $\$ 1.50$.

\section{TOBACCO}

CONNECTICUT SEED LEAF-The hardiest variety in eultivation. One of the best sorts for cigar wrappers. Pkt., 10c; 0z., 50c.

HAVANA (Domestic)-Pkt., 10c; oz., 50c.

\section{SQUASH}

(For cultural directions see page 6)

\section{Summer Varieties}

EARLY WHITE BUSH SCALLOP - A very early variety, with flat, creamy white scalloped squashes, 4 to 6 inches in diameter. The vine is bush in habit and rather dwarf. This variety is the common "Pattypan" squash. Pkt., 10c; 0z., 20c; I/4 lb., 45c; lb., \$1.25.

VEGETABLE OR ITALIAN MARROW (Cocozelle Bush) -An extremely early squash of compact bush growth. The color is dark green at first but changes to a lighter green as the fruit matures. Usually eaten when quite small but is still good for the table when nearly full grown. Pkt., 10c; 0z., 20c; I/4 lb., 60c; 1b., \$1.75.

ENGLISH VEGETABLE MARROW (Long White)-Skin greenish yellow; flesh white, soft and rich flavor. Pkt., $10 \mathrm{c} ;$ oz., 35c; r/4 lb., $\$ 1.00$.

YELLOW SUMMER CROOKNECK-A well-known Summer variety. The fruit is crooknecked, rich golden yellow and thickly warted; very tender when young. Pkt., 10c; 0z., 20c; 1/4 1b., 45c; lb., \$1.25.

\section{Winter Varieties}

BANANA-A wonderful yielder and good keeper. Two to three feet long, with a tough whitish green shell and delicious tasty meat. Very fine for winter. Pkt., 10c; oz., 20c; r/4 lb., 50c; lb., \$1.50.

BOSTON MARROW-The earliest of the Fall sorts. Large oval fruit; color of skin and flesh rich orange. Excellent flavor; keeps well. Pkt., 10c; oz., 20c; I/4 lb., 45c; lb., $\$ 1.25$.

DELICIOUS-One of the best sorts for wintem wo wrimhing from 5 to 10 pounds. Skin is green, flesh is thick and of a dark orange color, fine grained and of splendid quality. Pkt., 10c; 0z., 20c; 1/4 lb., 45c; lb., \$1.25.

HUBBARD-The best known Winter sort; of superior quality; large size. Fruit heavily warted, dark green in color with orange flesh. Pkt., 10c; 0z., 20c; I/4 lb., $45 \mathrm{c} ; 1 \mathrm{~b} ., \$ 1.25$.

PERFECT GEM OR CREAM-A long keeping Winter squash of small rounded form, 4 to 6 inches in diameter, skin cream colored and distinctly ribbed; fine for baking. Pkt., 10c; 0z., 20c; 1/4 lb., 45c; lb., \$1.25.

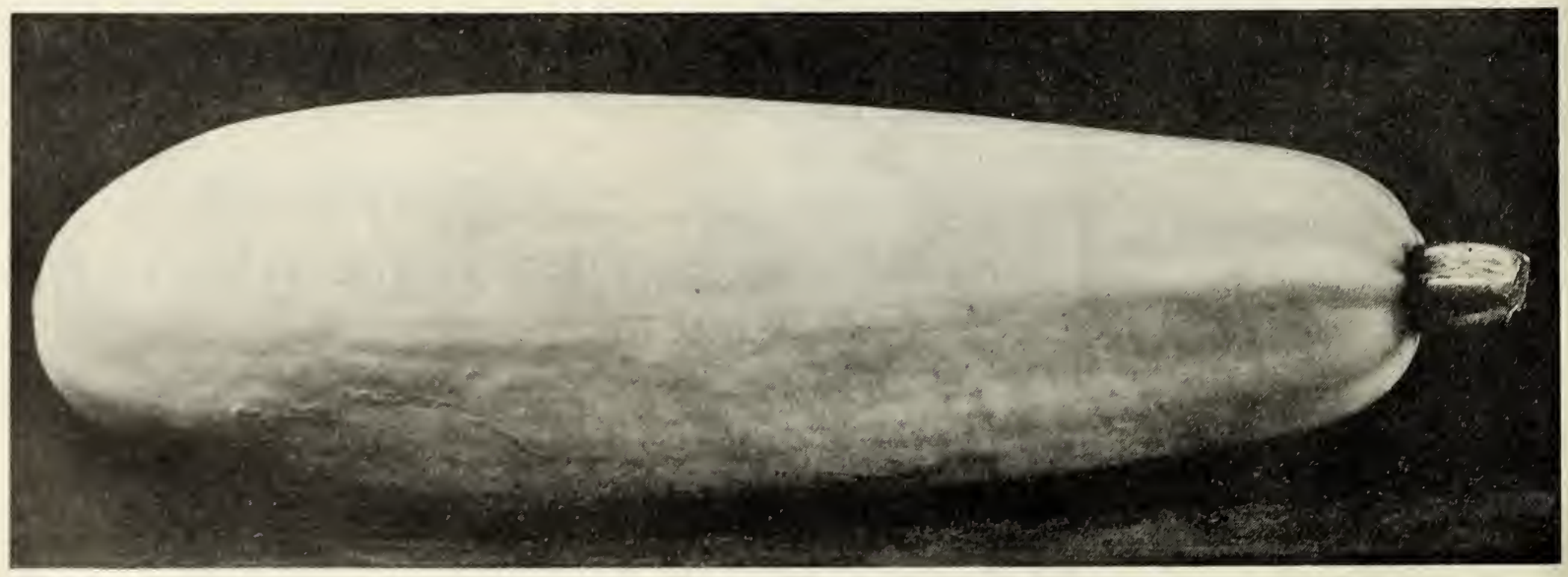




\section{TOMATO}

(For cultural directions see page 6)

BOUNTIFUL-A new forcing tomato of superior flavor, perfect in shape, of good size and setting freely. The fruits are bright red, very solid and grow in clusters of 7 to 9 . Pkt., 25c.

CHALK'S EARLY JEWEL-Very fine; large, solid, smooth and bright red; very early. Pkt., 10c; oz., 50c; I/4. lb., $\$ 1.50$.

DWARF GIANT “Tree Tomato"-Of dwarf compact growth, the plants are very productive. Fruit very large and smooth; flesh wonderfully solid, of finest flavor, with no core. Pkt., 10c; 0z., 65c; 1/4 lb., \$2.20.

EARLIANA-An extra early variety, producing large clusters of bright red fruit of medium size; very solid and of delicious flavor. Pkt., 10c; oz., 50c; 1/4 1b., $\$ 1.50$.

GOLDEN QUEEN-A large-fruited, tall variety, bearing smooth, bright yellow fruit of fine quality. Pkt., 10c; oz., 65 c; r $/ 4$ lb., $\$ 2.20$.

HUSK TOMATO, OR GROUND CHERRY-A variety that is covered by a loose covering or husk. The true edible variety is yellow and is used for preserves. Pkt., 10c; oz., 75c.

LIVINGSTON'S NEW CORELESS-Fruits are of large size, almost round and bright red. Clusters of 4 to 7 fruits are produced along the stem. Heavy cropper; an excellent slicing variety; almost entirely free from green core. Pkt., 10c; 0z., 65; 1/4 lb., \$2.20.

PONDEROSA - One of the largest varieties, frequently weighing 2 to 4 pounds each; of irregular shape but very solid. Pkt., 10c; 0z., \$1.00; 1/4 lb., \$3.00.

RED PEAR -The fruit is small and pear-shaped, being about 2 inches long and bright red. Pkt., 10c; 0z., 75c.

YELLOW PEAR-Pkt., 10c; oz., 75c.

RED PLUM-Fruit is oblong, about $1 \frac{1}{4} 4$ inches long. Pkt., 10c; oz., 75c.

YELLOW PLUM-Pkt., 10c; 0z., 75c.

SAN JOSE CANNER-The favorite canning sort and an excellent tomato for the table, as it is of a delicious flavor. It is large and meaty, deep red and prolific. Pkt., 10c; 0z., 75c; 1/4 lb., $\$ 2.50$; lb., $\$ 7.50$.

STONE-One of the largest and most solid late varieties. Fruit very smooth, large and uniform in size; bright, scarlet, unsurpassed for canning and slicing. Pkt., 10c; oz., 50c; r/4 lb., $\$ 1.50$.

\section{TURNIP}

(For cultural directions see page 6)

AMBER OR YELLOW GLOBE-A large, light yellow globe-shaped variety; flesh firm and sweet. Pkt., 10c; oz., 20c; 1/4 lb., 35c; lb., \$1.00.

EARLY SNOWBALL-A nearly round, medium-sized turnip with smooth white skin maturing very early. Very sweet and tender. Pkt., 10c; 0z., 20c; I/4 lb., 35c; lb., $\$ 1.00$.

EARLY WHITE FLAT DUTCH, STRAP-LEAVED-A medium-sized flat variety, clear, white, of quick growth and excellent quality. Pkt., 10c; oz., 20c; 1/4 lb., 35c; lb., $\$ 1.00$.

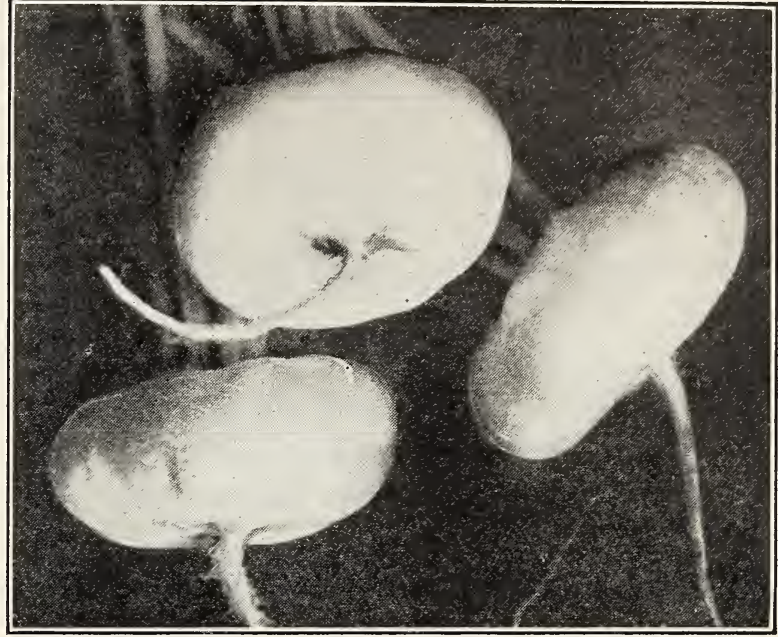

Purple-Top Strap-Leaved Turnip

EXTRA EARLY PURPLE TOP MILAN-The earliest turnip grown, being ready two weeks sooner than any other variety; medium-sized, very flat and white with purple top. Pkt., 10c; oz., 20c; r/4 lb., 45c; lb., \$1.25.

EXTRA EARLY WHITE MILAN-An extra early variety with clear white skin and flesh. Pkt., 10c; oz., $20 \mathrm{c} ; \mathrm{r} / 4$ lb., 45c; lb., \$1.25.

GOLDEN BALL, OR ORANGE JELLY-A globe-shaped yellow variety of medium size; flesh firm and crisp. An excellent table sort. Pkt., 10c; oz., 20c; 1/4 lb., 35c; lb., $\$ 1.00$.

LONG WHITE OR COW HORN-Rather slender, tapering roots six to eight inches in length and measuring one and a half to two inches in diameter. The roots grow half their length above the surface and are pure white. Pkt., 10c; 0z., 20c; 1/4 lb., 35c; lb., $\$ 1.00$.

PURPLE-TOP STRAP-LEAVED-Flat, medium size, purple above ground, white below. Flesh fine grained and mild flavor. One of the most largely used variety. Pkt., 10c; 0z., 20c; I/4 lb., 35c; 1b., \$1.00.

PURPLE TOP WHITE GLOBE-A valuable sort for either table use or stock feeding. Roots globe-shaped, white with purple top. Flesh white, firm and tender; very large. Pkt., 10c; 0z., 20c; 1/4 1b., 35c; 1b., \$1.00.

SEVEN TOP-Grown exclusively for its leaves. Cooked same as spinach and mustard. Pkt., 10c; oz., 20c; I/4 lb., 35c; lb., $\$ 1.00$.

WHITE EGG-A very smooth egg-shaped variety, maturing very quickly. Flesh pure white, fine grained, very sweet. Pkt., 10c; 0z., 20c; I/4 lb., 35c; lb., \$1.00.

\section{Ruta Baga or Swedes}

AMERICAN PURPLE TOP, OR LONG ISLAND-One of the best and most popular yellow fleshed varieties. It is yellow below ground, with purple top above. A fine table or stock feeding variety. Pkt., 10c; oz., 20c; I/4 lb., 35c; lb., $\$ 1.00$.

LARGE WHITE, OR SWEET-A very large variety with white skin and white flesh, which is tender and sweet. Pkt., 10c; 0z., 20c; I/4 lb., 35c; lb., $\$ 1.00$. 


\section{HERB SEEDS}

Sow early in spring in slrallow drills, 1 foot apart; when up a few inches thin out or transplant.

ANISE-For seasoning. also for tlavoring liquors; ammual. Pit., 10c; 0z., 30c.

BALM-Lenton scented; peremial. Pkt., 10c; oz., 60c.

BASIL, SWEET-The stems and soeds are used in soups and siluces: anmual. Pkt., $10 \mathrm{c} ; 0 z ., 40 \mathrm{c}$.

BORAGE - Evicllent for bees; ammal. Pkt., 10c; oz., 30c. CARAWAY cieeds used in bread and calies; biennial. Pkt., $10 c ; 0 z ., 25 c$.

CATNIP-For medicinal purposes; perennial. Pkt., 10c.

CHIVES - Leraves lave a mild onion flavor and are used in sullps and saladds; pereminial. Pkt., 15c

CORIANDER ceeds are used for flavoring; anmual. Pkt., $10 \mathrm{c} ; 0 \mathrm{z}, 25 \mathrm{c}$.

DILL, MAMMOTH-Leaves used in pickles and sauces; almmial. Pkt., 10c; oz., 20c.

FENNEL, SWEET-For soups and salads; perennial. Pkt., 10c; oz., 25c.

FLORENCE FENNEL_A veretable with a flavor somewhat like celery, but it has a sweet taste. Pkt., 10c; $0 z ., 25 c$.

LAVENDER - For perfuming linen; perennial. Pkt., 10c; oz., 65c.

ROSEMARY_Leaves used for seasoning; perennial. rkt., $10 c ; 0 z ., 50 c$.

RUE-For medicinal purposes; perennial. Pkt., 10c.

SAGE-I.caves used for scasoning and stufling; excellent fur hese: rereminial. Pkt., 10c; oz., 50c.

SAVORY, SUMMER - Ieaves and young shoots used for Havoring; anmmal. Pkt., 10c; oz., 35c.
SAVORY, WINTER-Perennial. Pkt., 10c; oz., 50c. SWEET MARJORAM-Leaves used both green and dried for sea soning; perennial. Pkt., 10c; oz., 50c.

TANSY-For medicinal purposes; perennial. Pkt., 10c.

THYME-Leaves used for seasoning; perennial. Pkt., 10c; oz., 75c.

WORMWOOD-Leaves used in medicines and liquors; peremial. Pkt., 10c; oz., 60c.

\section{HERB PLANTS}

li wanted by parcel post within the end zone add 10c for one plant and 3c extra for each additional plant, to cover postage and packiner.

MINT, ROSEMARY, SAGE, SAVORY, SWEET MARJORAM and THYME-Pot grown plants, Each, 20c.

CATNIP-Pot grown plants. Each, 25c.

CHIVES-Clumps of 2 for 25.

HORSE RADISH-January to May delivery. Roots 50c per doz., postpaid; $\$ 2.50$ per 100 , postpaid.

\section{BIRD SEEDS}

If ordered by parcel post, add postage at zone rates. These prices fluctuate and are not guaranteed. CANARY SEED-2 lbs. for 25c; $10 \mathrm{lbs}$, \$1.25. HEMP - 1 lb., 10c; 3 lbs., for 25c; $10 \mathrm{lbs}$., 75c. MILLET, Recleaned-1 lb., 10c; 3 lbs., 25c; 10 lbs., $75 \mathrm{c}$. RAPE, Imported-2 lbs., 25c; 10 lbs., \$1.25.

MIXED BIRD SEED - 1 lb., 10c; 10 lbs., \$1.00. SUNFLOWER-2 lbs., 25c; 10 lbs., $\$ 1.00$.

\section{Printer's Correction}

Hallawell's Evergreen Lawn Mixture priced as follows:

Per lb., 30c; 10 lbs., $\$ 2.50$<smiles>[123IH]</smiles>

\section{Should Be}

Per lb., 60c; 10 lbs., $\$ 5.50$

\section{LAWN GRASSES}

are recleaned and of the very best grade. They can be sown in Calijroviding there is plenty of water available. Prepare the ground by ighly with well-decayed manure and then rake the surface smoothly. ake it in so that it will be covered lightly. After sowing, the ground oress the seed firmly into the soil. Water daily until well started. One equired for 100 square feet of lawn and one pound of Kentucky Blue 150 square feet of lawn.

er quantities; these prices fluctuate and are not guaranteed. within the fourth $\mathrm{z}$ one on pound and 10-lb. lots of seeds.

1.y; extra rlean. The is a dark green and of beantiful turf in a leavy or hlack soil. Per lb., 60c; 10 lbs., \$5.50.

HALLAWELL'S EVERGREEN LAWN MIXTURE-A mixture of several decp green grasses which makes a thick sturly lawn. renaining green both Summer and Winter. It is esperially arlatpted for heavy or black nils. Per lb., 30c; 10 lbs., \$2.50.

AUSTRALIAN RYE GRASS-A very vigorous, quick growing lawn frass, but a little coarse. Very satisfac. tory for lawns in San Francisco. Best grass for sandy snils. Per lb., 30c; 10 lbs., $\$ 2.50$.

PACIFIC RYE GRASS (Genuine Parey's Rye Grass)This grass is similar to the Australian Rye Grass. but has a finer lea $\hat{f}$ and is longer lived. Per lb., 35c; $10 \mathrm{lbs}$, $\$ 3.00$.

WHITE CLOVER - Oi dwarf habit with creeping stems, rooting at joints, on which account it makes an excellont turf that stands constant tramping. Planted for a lawn either alone or in mixture with grass seed. Per lb., 75 c; 10 lbs., $\$ 6.50$.
GOLDEN GATE LAWN MIXTURE-This mixture of hardy grasses contains a little white clover and forms a thick, strong turf that will stand hard usage. Per lb., $40 \mathrm{c} ; 10$ lbs., $\$ 3.75$.

SHADY NOOK MIXTURE-This mixture contains grasses for making good lawns in shady places and under trees. Per lb., $\$ 1.00 ; 10$ lbs., $\$ 9.00$.

CHEWING'S FESCUE-Forms a close, lasting turf, succeeding well even under poor conditions. It is used extensively in lawn and putting green mixtures. Per lb., $60 \mathrm{c}$.

CREEPING BENT-Being of fine texture this grass is excellent for lawns and putting greens; makes a low velvety growth. Per lb., \$2.50.

RED TOP GRASS-Gives a quick effect and succeeds on all soils, though doing best on moist soils. Should be in all lawn mixtures. Per 1b., 50c; 10 lbs., $\$ 4.50$.

WOOD MEADOW GRASS-Thrives under trees and shady places. Per lb., $\$ 1.50$.

(Fortilizers for Lawns, see page 93) 


\section{FIELD AND GRASS SEEDS}

Owing to frequent market fluctuations on Clover and Field Seeds, we do not list the 100pound price, but request that all who are interested in quantities will write us for samples and quotations. Prices now given are those prevailing when the catalogue was published.

Charges prepaid on pound and 10-pound lots anywhere within the fourth zone.

ALFALFA or LUCERNE (Medicago Sativa)-Produces 3 or 4 heavy crops of hay in a season. 17 to 25 pounds required per acre. Sow in the Fall or Spring. Lb., 50c; 10 lbs., $\$ 4.00$.

ALFALFA, HAIRY PERUVIAN-Starts to grow while weather is yet cool and makes one or more additional cuttings a season. Lb., 50c; 10 lbs., $\$ 4.00$.

ALSIKE or SWEDISH CLOVER (Trifolium Hybridum) Sncceeds on wet soils. Sow 8 to 10 pounds per acre. Lb., 50c; 10 lbs., $\$ 4.50$.

AWNLESS BROME GRASS (Bromus Inermis)-A valuable grass for dry light soils, producing heavy crops. Sow 35 pounds per acre. Lb., $50 \mathrm{c}$.

BERMUDA GRASS (Cynodon Dactylon) - The seed requires 15 days of hot moist weather to germinate. Sow 10 to 15 pounds per acre. Lb., 65c; $10 \mathrm{lbs}$., $\$ 6.00$.

BOKHARA or SWEET CLOVER (Melilotus Alba)Grown for bee food, also good for cattle pasture and for hav. Sow 10 to 15 pounds per acre. Lb., 30c; 10 lbs., $\$ 2.50$.

BURR CLOVER (Medicago Denticulata)-Sow from August to Ortober, using 15 to 20 pounds per acre. Lb., 35c; 10 lbs., $\$ 3.00$.

CANADA FIELD PEAS-Planted in the Fall for green manure. Sow 75 pounds per acre broadcast. Lb., 20c.

COW PEAS, BLACK EYE-Used largely for green manure. Sow late in Spring, using 20 pounds per acre if drilled. Lb., 20c.

DWARF WHITE MILO_Sow 4 pounds per acre in drills when ground has warmed up. Lb., 20c.

E G Y P T I A N or JERUSALEM CORN-Excellent for chickell feed; 8 pounds required per acre. Sow last of April or in May. Lb., 20c.

FETERITA-Same feeding qualities as Egyptian Corn; rields 2 to 3 tons per acre. Sow in May, using 4 pounds per acre. Lb., $20 \mathrm{c}$.

KAFFIR CORN-Grows 6 to 10 feet high: makes good fodder for cattle; seed is used for stock and chicken food. Sow in rows 3 feet apart, using 5 pounds per acre. Lb., $20 \mathrm{c}$.

MILLET, GOLDEN (Panicum Germanicum)-An annual hay and fodder crop. Sow 30 pounds per acre. Lb., $20 \mathrm{c}$.

MELILOTUS INDICA (Bitter Clover)-A hardy Winter growing cover crop for green manuring. It grows 5 feet in 4 months from seed. Sow shallow, using 10 to 15 pounds per acre. Lb., 20c; 10 lbs., $\$ 1.50$.

ORCHARD GRASS or COCKSFOOT (Dactylis Glomerata) -One of the most valuable of the pasture grasses; makes a good hay. Sow 35 pounds per acre. Lb., 35c; 10 lbs., $\$ 3.00$.
PERENNIAL RYE GRASS (Lolium Perenne)-The great pasture and meadow grass of Great Britain; valuable for planting early on dry hillsides, as it grows so very quirkly. Sow 60 pounds per acre. Lb., 30c; $10 \mathrm{lbs}$., $\$ 2.50$.

RAPE, DWARF ESSEX-A biennial crop used principally for sheep and hog pasture. Sow broadrast, using 4 to 5 pounds per acre. Lb., 25c; 10 lbs., $\$ 1.80$.

RED CLOVER (Trifolium Pratense)-The best clover for all practical purposes. Sow 15 pounds per acre. Lb., $60 \mathrm{c} ; 10$ lbs., $\$ 5.00$.

SPRING VETCHES or TARES (Vicia Sativa) - Highly valuable for forage or green manure; makes a fine Winter growth. Sow 60 pounds per acre with grain or 80 to 100 pounds if sown alone. Lb., 20c; $10 \mathrm{lbs}$., $\$ 1.50$.

SUDAN GRASS-An annual forage plant used both for hay and silo. Cut with a mower just after full bloom. Two cuttings are assured and in some places four. It yields from 2 to 8 tons per acre. depending upon whether irrigated or not. Plant late in Spring after frost is past. If drilled in rows 18 inches apart, 4 to 6 pounds per acre is required; if in rows 36 inches apart, 2 to 4 pounds per are; and if sown broadeast, 15 pounds per acre. Lb., 25c; $10 \mathrm{lbs}$., $\$ 2.00$.

SUGAR CANE SORGHUM, EARLY AMBER - A good fodder if cut when 2 feet high, or good silage if cut when full grown. Sow late in April, using 5 pounds per acre in drills or 25 pounds broadeast. Lb., $20 \mathrm{c}$.

SUNFLOWER, LARGE RUSSIAN_The best variety for poultry food. Sow in the open field when frost is past. using 3 pounds of seed per acre, sowing in rows 5 feet apart and thinning to 1 foot. Lb., $20 \mathrm{c}$.

TIMOTHY (Phleum Pratense)-The standard hay of com merce of the eastern part of the country. Will stand extreme cold and rield very heavily. Often sown with Red Top and Red Clover. Sow 15 to 20 pounds per acre. Lb., 20c; 10 lbs., $\$ 1.50$.

\section{TREE SEEDS}

Acacia seeds should be soaked in hot water for twelve hours or more before sowing.

(Pkt., 15c, except where noted.)

ACACIA BAILEYANA-Oz., 50c.

ACACIA FLORIBUNDA-Oz., 50c.

ACACIA MELANOXYLON-Oz., 50c.

ACACIA MOLLISSIMA-Oz., $50 \mathrm{c}$.

CYPRESS MONTEREY-Oz., 50c.

CYPRESS ITALIAN-Oz., 50c.

DRACAENA AUSTRALIS-Oz., 60c.

EUCALYPTUS FICIFOLIA (Scarlet Flowering Gum) $25 \mathrm{c}$ per pkt. of 25 seeds; 100 seeds, $85 \mathrm{c}$.

EUCALYPTUS GLOBULUS (Blue Gum)-Oz., 75c; 1b., $\$ 7.50$.

GENISTA HISPANICA (Spanish Broom)-Oz., 50c.

PEPPER TREE (Schinus Molle)-Oz., 20c.

GREVILLEA ROBUSTA (Silk Oak)-Oz., 60c.

PHOENIX CANARIENSIS (Date Palm)-100 seeds, 50c.

PINUS RADIATA (Monterey Pine)-Oz., 50c.

SEQUOIA GIGANTEA (Cal. Big Tree)-Pkt., 25c; Oz., $\$ 2.50$.

SEQUOIA SEMPERVIRENS (California Redwood)-Oz., $50 \mathrm{c}$.

WASHINGTONIA ROBUSTA (Fan Palm)-Oz., 25c. 


\section{Seasons to Sow Flower Seeds in Central California}

This list enables one to tell at a glance when the various flower seeds may be sown. As some perennials will bloom the same season if sown early in the year, we therefore have stated the latest time in Spring they may be sown to bloom the same season; in regard to perennials that will not bloom the same year if planted in Spring, we have stated the time they should be sown in Fall to bloom the coming Summer. Also the time they may be sown in Spring to bloom early the following year. Several varieties of hardy annuals if sown in the Fall will come into bloom earlier than if sown in the Spring, even if the plants do not make much progress during the cold weather. Tender and half hardy annuals, if sown early, should be started in a warm, sheltered position and transplanted when the cold weather is over.

$\begin{array}{lll}\text { HA-Hardy Annual. } & \text { TP-Tender Perennial. } & \text { HHP-Half Hardy Perennial. } \\ \text { HP-Hardy Perennial. } & \text { HHA-Half Hardy Annual. } & \text { TA-Tender Annual. } \\ & \text { HB-Hardy Biennial. }\end{array}$

Abronia HA.

Achillea HP

Achimines TP

Acroclinium HA

Ageratum HHA.

Agrostemma HP

Alyssum HHA.

Alonsoa HHA.

Amaranthus TA.

Ampelopsis HP.

Anagallis $\mathrm{HA}$.

Anchusa Dropmore HP.

Anchusa Capensis HA.

Anemone HP.

Arabis HP.

Arctotis HA.

Asparagus. $\mathrm{HP}$

Aubrietia HP. $\dddot{\text { Australian Pea }} \ddot{\mathrm{H}} \ddot{\mathrm{HP}}$

Aster HHA

Aster Perennial HP.

Balloon Vine TA.

Balsam TA.

Bartonia HA.

Begonia.

Brachycome HA.

Browallia HA.

Calceolaria

Calendula $\mathrm{HA}$

Calliopsis HA.

Campanula HP.

Canterbury Bells HB

Canary Bird Flower TA.

Candytuft HA.

Candytuft, Perennial H

Carnation HP

Castor Bean H HP

Canna HP.

Cardinal Climber $\ddot{\mathrm{T}}$ A

Celosia (Cockscomb) TA

Celsia Arcturus.

Centaurea Sweet Sultan IIA.

Cerastium HP

Cheiranthus HP.

Chrysanthemum Annual $\ddot{H} \ddot{A}$

Chelone HP.

Cineraria HHP.

Clarkia HA.

Cleome TA

Cobaea HP.

Coleus TP

Collinsia HA

Coreopsis HP Bachelor's Button HA.

Cornflower or

Columbine HP.

Cyclamen TP

Cynoglossum HP.

Cypress Vine TA.

Dahlia, Single HHP

Dahlia, other sorts.

Daisy HP.

Daisy, Shasta HP
September to May

August to March

March and April

October to June

Aug. to Oct., Feb. to May

February to May

August to March

All year round

February to May

February to May

August to $\mathrm{May}$

September to June

Aug. to Nov., Feb. to May

October to May

April to June

Aug. to Oct., Feb. to June

September to May

August to May

August to October

August to May

February to June

August to March

March 15 to May

February to June

October to June

Feb. to Mar., Aug. to Oct.

February to June

February to June

June to August

All year round

February to June

Aug. to Oct., Feb. to May

April 15 to June

October to May

March 15 to June

All year round

Aug. to Nov., Feb. to May

October to April

March to June

February to June

April and May

March to June

Jan. to Mar., June and July

October to April

Aug. to Nov.. Feb. to May

August to March

.February to June

Aug. to Oct.. Feb. to May

Aug. to Nov., Feb. to May

September to June

March 15 to May

Aug. to Nov.. Feb. to May

March to May

October to May

August to March

September to May

Aug. to Oct., Feb. to May

February to June

August to March

Aug. to Nov., Feb. to May

April and May

February to May

February and March

September to April

Aug. to Nov., Feb. to May

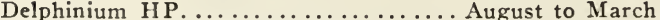

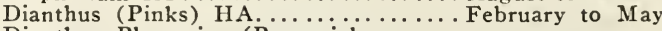

Dianthus Plumarius (Perennial

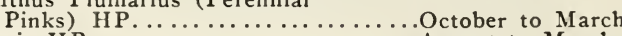

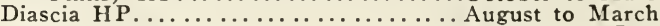

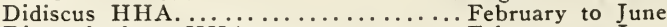

Dimorphotheca HHA................................ June

Dolichos, Hyacinth Bean $\mathrm{TA} . . . . . . .$. April and May

Eschscholtzia (California Poppy HA). September to May

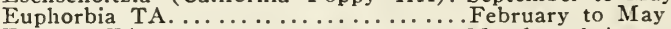

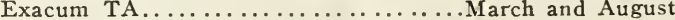

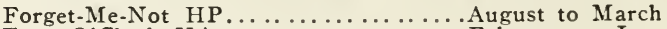

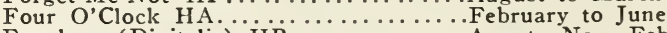

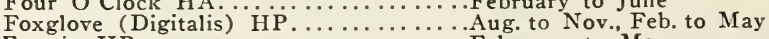

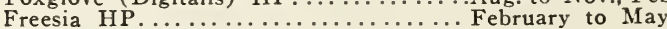

Gaillardia, Annual....................................

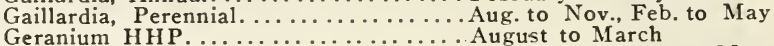

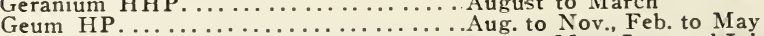

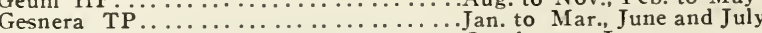

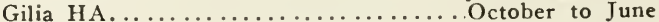

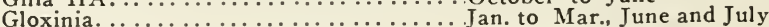

Godetia $\ddot{\mathrm{HA}}$

Gourds TA

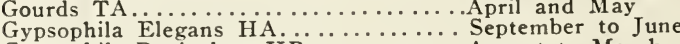

September to June

Gypsophila Paniculata HP........... August to March

Helichrysum HA

Heliopsis HP

Heliotrope H HP

Heuchera HP.

Hibiscus HHP

Hollyhock HP.

Honesty HP.

Humulus (Jap Hop) $\ddot{H} \ddot{A}$

Hunnemannia $T$ A.

F'ebruary to May

Aug. to Nov., Feb. to May

Aug. to Nov., Feb.

Aug. to Nov., Feb. to May

August to March

August to March to May

August to March

February to May

Impatiens TP.

February to May

I pomoea (Moonflower) Ḧ.................................. May

Jacobea HA. .

February to June

Kenilworth Ivy HP.

September to May

Kochia II A

February to May

Kudzu Vine $\mathrm{T} \ddot{\mathrm{P}}$

September to May

Larkspur, Annual

October to May

Larkspur or Delphinium $\mathrm{H} \mathrm{P}$.......... August to March

Lathyrus HP.

August to March

Lavatera Splendens $\mathrm{HA}$.

April to June

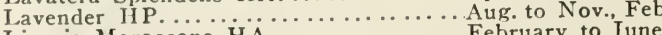

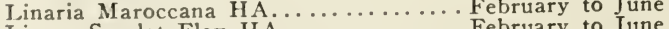

Linum Scarlet Flax HA............................. June

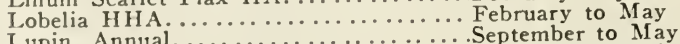

Lupin, Annual.

Lupin, Perennial.

September to May

Lychnis HP.

Aug. to Nov., Feb.

Lythrum HP.

Aug. to Nov., Feb. to May

Marigold HA.

February to May

Matthiola $\mathrm{HA}$

September to May

Iatricaria HHP. 


\section{Seasons to Sow Flower Seeds-Continued}

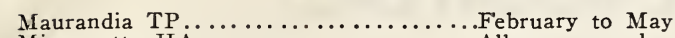

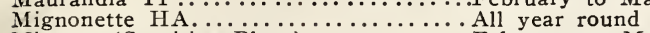
Mimosa (Sensitive Plant)............... February to May

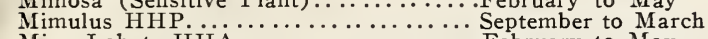
Mina Lobata HHA............... February to May Morning Glory $\mathrm{HHA} . \ldots \ldots \ldots \ldots \ldots \ldots \ldots \ldots \ldots$ February to May

Nasturtium TA.............................. 15 to June

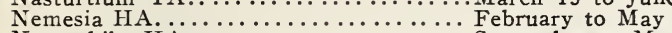

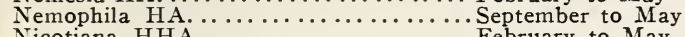
Nicotiana HHA.................... Nigella HA.............................

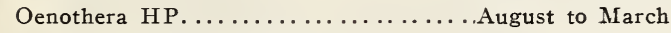

Pansy, for Spring blooming HA....... August to November Pansy, for Summer and late blooming HA............... February to May Pentstemon HP.................... August to March

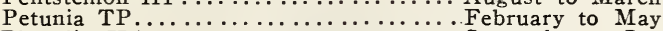

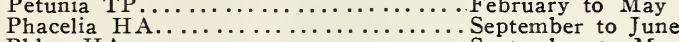

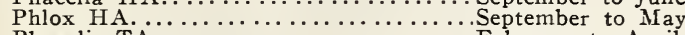

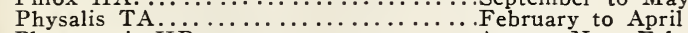

Physostegia HP.................... Aug. to Nov., Feb. to May Platycodon HP..................... August to March

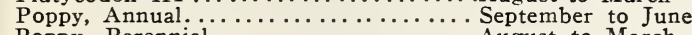

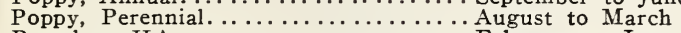

Portulaca HA. ........................ February to June

Primrose. .........................

Primula, Chinese.................. March to May

Pyrethrum (Golden Feather) HP.......... September to May

Pyrethrum Hybrids HP........................ to Nov., Feb. to May

Ranunculus HP....................... to June

Rehmannia HHP............................ to Nov., Feb. to May

Rhodanthe HA.

Rudbeckia, Annual........................

Rudbeckia Purpurea H.......................... to Nov., Feb. to May

Salpiglossis HHA.................. February to April

Salvia HHP..................... February to May

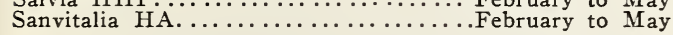

\section{How to Raise Flowers}

Tender, or Greenhouse, means the plant will not stand the least frost. All such must be planted out late in Spring (May) or in a greenhouse.

Half Hardy means the plant will stand any light frost, but needs protection against very cold weather. These should be planted out in the Spring (March and April), not in the Fall.

Hardy means the plant will stand considerable frost, or practically all we have on the Pacific Coast. These may be planted in the Fall or in the Spring (October to May). If sown in the Fall they will come into bloom earlier than if sown in Spring, even if the plants do not make much progress during the cold weather.

Annuals are plants that bloom the first year from seed, and the plant dies after one season. Tender annuals must be sown in Spring (April to June), and hardy annuals may be sown either in Spring or Fall (October to May).

Biennials are plants that bloom the second year from seed, and the plant dies after the second year. In California many of these will bloom the first year if sown early. Sow under the same conditions as perennials.

Perennials are plants that bloom the second year from seed, and the plant lives and blooms during successive years. If sown in early Spring (February to March), many perennials will bloom the first year from seed. Tender and half hardy perennials are best sown in Spring after frost is over (April 15th to June). Hardy perennials are best sown in the late Summer and early Fall (July to October) for next year's flowers.

Cultural Directions-It is better in most instances, except hardy annuals, to start the seed in shallow boxes which should be about 4 inches in depth, using very sandy soil
Saponaria Ocymoides HP................... to Oct., Feb. to May

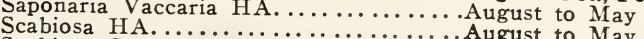

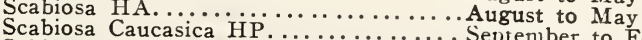

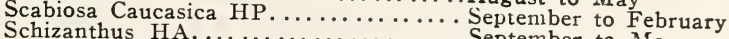

Schizanthus HA. Sh $_{\text {Sinter }}$ blooming $\ldots \ldots \ldots$. in pots HA.

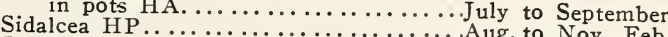

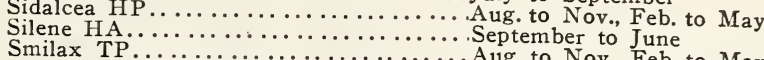

Smilax TP................................. to Nov., Feb. to May

Snapdragon, for Summer and Fall

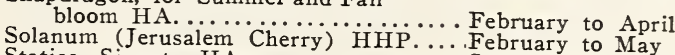

Solanum (Jerusalem Cherry) HHP..... February to May

Stevia Serrata HP...................................... to Nov., Feb.

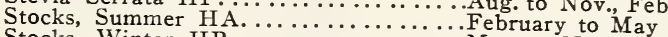

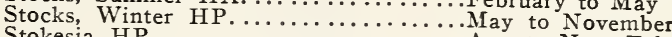

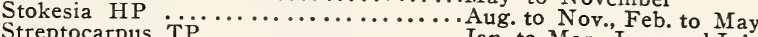

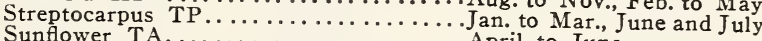

Sunflower TA.

Sweet Rocket HP.

April to June

Sweet William HP

September to June

Thunbergia HA.

Torenia HHA.

Trachelium HP.

Aug. to Nov., Feb. to May

Aug. to Oct., Feb. to May

Valerian HP.

Verbena, for Spring bioom HHP

Verbena, for Summer bloom HHP

Veronica HP.

Vinca TP

Viola (Tufted Pansies) HP

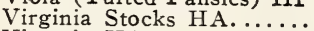

Viscaria HA.

Wallflower HP. .

February to May

February to May

Aug. to Nov., Feb. to May

Xeranthemum HA.

Aug. to Nov., Feb. to May

August to November

February to May

Aug. to Nov., Feb. to May

Jan. to Mar., June and July

April to November

All year round

February to June

Zinnia HHA.

May and June; Sept. to Feb.

February to May

February to June

\section{Successfully from Seed}

with leaf mold so that it will not bake, and provide for drainage by boring some holes in the bottom of the box. Set the boxes in a warm sheltered place, but protect from direct sunlight, as the seed is liable to be scorched up. When the plants have made the fourth leaf they should be pricked out, reset in another box or preferably in paper pots and when well started they should be transplanted into the garden. If the seed is to be sown directly in the garden, it should be done after the soil is well worked and fertilized. A slight depression should be made with a stick, the seed sown, and then covered with sharp sand about twice the depth of the diameter of the seed. The sand will prevent the crusting over of the soil after watering.

When up, the plants must be thinned from 2 to 12 inches, depending on the variety, otherwise they will be weak and spindling. Always keep the weeds out.

A common mistake in sowing flowers, as well as other seeds, is covering too deep. As a general rule, cover only to the depth of the thickness of the seeds; or, with mediumsized seeds, like Balsams, Zinnias, etc., a quarter of an inch or less is the proper depth. Such fine seeds as Portulacas, Nicotiana, etc., need only to be pressed into the soil with a piece of board or the palm of the hand. Always press the earth down firmly after sowing all flower seeds, else there is danger of their drying up before the roots can get firm hold of the soil. Seeds of the hardier annuals may be sown where they are to grow; but as a rule, it is preferable to transplant, as the plants are generally stronger and stand the drought better. During very dry weather, and when the seedlings are first set out, they should be watered frequently. Provide some support for all such annuals as require it.

The weeds should be kept down and the ground loosened often, so that the plants will receive the full benefit of the rains and dews, which they will not if the ground is allowed to become hard and baked. Water often. 


\section{CLASSIFICATION OF FLOWERS}

To enable one to tell at a glance what flower's are suitable for any position, we have classified all the different flower's of which we sell seed, into the following classes.

Where any variety is suitable for two uses, we have entered it under both lists.

Peremials are separated from Annuals, and Biennials are classed with the Perennials. Plants which will do well in a shady location we have indicated by (s) after the name, and those that will do well in a partially shaded location are indicated by (ps).

\section{SEED OF GREENHOUSE PLANTS}

$\begin{array}{ll}\text { Achimenes } & \text { Exacum } \\ \text { Asparagus Fern } & \text { Gesnera } \\ \text { Auricula } & \text { Gloxinia } \\ \text { Begonia Tuberous } & \text { Impatiens } \\ \text { Begona, Fibreus Rooted } & \text { Mimosa } \\ \text { Browallia Major } & \text { Jemesia } \\ \text { Calceolaria } & \text { Physalis } \\ \text { Celosia Glasgow Prize } & \text { Primula } \\ \text { Celosia Pride of Castle Gould } & \text { Rehmannia } \\ \text { Celin Arcturus } & \text { Schizanthus } \\ \text { Cinerdria } & \text { Solanum } \\ \text { Coleus } & \text { Streptocarpus } \\ \text { Cyclamen } & \text { Torenia } \\ \text { Diascia } & \text { Vinca }\end{array}$

BEDDING PLANTS, PERENNIAL From 1 to 2 Feet $\mathrm{High}$

\begin{tabular}{|c|c|}
\hline $\begin{array}{l}\text { Achillea } \\
\text { Argostenma } \\
\text { Begonia, Fibrous Rooted (ps) } \\
\text { Beguma, Tuberous (ps) } \\
\text { Candytuft. Perennial } \\
\text { Carnation Montana } \\
\text { Centaurea (s) } \\
\text { Cineraria (s) } \\
\text { Columbine (ps) } \\
\text { Coreop-is } \\
\text { Cynuglissum } \\
\text { Dalsy, Shasta } \\
\text { Forget-Me-Not (s) } \\
\text { Gaillardia } \\
\text { Geum }\end{array}$ & $\begin{array}{l}\text { Linum Perenne } \\
\text { Lychmis } \\
\text { Pentstemon } \\
\text { Physostegia } \\
\text { Platycodon } \\
\text { Potentilla } \\
\text { Pyrethrum Grandiflorum } \\
\text { Salvia Patens } \\
\text { Stevia Serrata } \\
\text { Stocks, Perpetual } \\
\text { Sweet William } \\
\text { Trachelium } \\
\text { Verbena (Speedwell) } \\
\text { Weronica (Spllfower (ps) }\end{array}$ \\
\hline
\end{tabular}

lleuchera Sanguinea

ANNUAI BEDDING PLANTS or Tall Border Plants

1 to 2 Feet

$\begin{array}{ll}\text { Ageratum, Tall } & \text { Grasses Ornamental } \\ \text { Alonsoa } & \text { Gypsophila (for bouquets) } \\ \text { Anchu-a Capensis } & \text { Hunnemannia, or Bush } \\ \text { Arctotis Grandis } & \text { Eschscholtzia } \\ \text { Aster } & \text { Jacobea } \\ \text { Balsam } & \text { Leptosyne } \\ \text { Bartonia Aurea } & \text { Linum, Scarlet Flax } \\ \text { Brachycome } & \text { Lupins } \\ \text { Browallia } & \text { Matricaria } \\ \text { Calendula } & \text { Marigold, French } \\ \text { Candytuft } & \text { Matthiola } \\ \text { Centaurea } & \text { Mignonette } \\ \text { Chrysanthenum } & \text { Nasturtiums, Dwarf } \\ \text { Clarkia } & \text { Nigella, or Love-in-a-Mist } \\ \text { Collinsia } & \text { Petunia } \\ \text { Iianthus } & \text { Poppy } \\ \text { Didiscus } & \text { Phlox } \\ \text { Dimorphotheca } & \text { Saponaria Vaccaria } \\ \text { Eschscholtzia, or California } & \text { Schizanthus } \\ \text { Poppy } & \text { Snapdragon, Dwarf } \\ \text { Euphorbia Variegata } & \text { Statice } \\ \text { Four o'Clock } & \text { Stnck, Ten Weeks } \\ \text { Faillardia } & \text { Ziscaria } \\ \text { Gilia } & \text { Zinnia }\end{array}$

TALI GROWING PLANTS, PERENNIAI For Grouping; \{rom $2 \frac{1}{2}$ Feet Up

I.avender

1.rbelia Cardinalis

1.ythum Roseum

I.upin

Oenothera

Poppy, Oriental

Rehmannia

Salvia Azurea

Salvia Splendens

Salvia Farinacea

Srabiosa Caucasica

Sidalcea

Sweet Rocket

Thalictrum (ps)

Valerian (s)

Verbascum

Wallfower (ps)
Hollyhock

Lavatera

TALI GROWING PLANTS FOR GROUPING, ANNUAT. From $21 / 2$ Feet Up

Anaranthus

Calliopsis

Celosia, Tall

Cleome

Cosmos

Euphorbia

Helichrysum

Honesty

Kochia

Marigold, Tall African

Larkspur Anuual

\author{
Lavatera Splendens \\ Nicotiana \\ Poppy, Double \\ Rudbeckia \\ Salpiglossis \\ Scabiosa \\ Snapdragon, Giant \\ Sunflower \\ Tithonia \\ Zinnia, Giant
}

\section{LOW EDGING PLANTS, ANNUAL}

6 to 12 Inches High

Ageratum, Dwarf

Alysium

Anagallis

Calliopsis Tiger Star

Candytuft, Dwarf

Celosia, Dwarf

Dianthus

Linaria Maroccana

I. obelia Compacta

Matricaria, Golden Ball

Mignonette (s)
Nemophila
Oenothera Rosea
Pansy (ps)
Portulaca
Silene
Sweet Peas, Cupid
Tagetes Signata
Torenia Stocks

IOW EDGING PLANTS, PERENNIAL

6 to 12 Inches High
Agathea

Anemone

Arabis

Aubretia

Border Pinks

Campanula Carpatica

Centaurea, Dusty Miller

Cerastium
Alyssum Saxatile
Daisy, English

Dianthus Plumarius

Diascia

Forget-Me-Not (s)

Freesia

Poppy, Iceland

Primula, Polyanthus (s)

Pyrethrum, Golden Feather

Ranunculus (ps)

Viola (ps)
PLANTS FOR ROCKERIES

$\begin{array}{ll}\text { Abronia Umbellata } & \text { Iberis } \\ \text { Alyssum Saxatile } & \text { Kenilworth Ivy (s) } \\ \text { Arabis } & \text { Lobelia, Trailing } \\ \text { Aubrietia } & \text { Nasturtium } \\ \text { Cerastium } & \text { Portulaca } \\ \text { Dianthus Caesius } & \text { Saponaria Ocymoides } \\ \text { Diascia } & \text { Statice Iatifolia } \\ \text { Forget-Me-Not (s) } & \text { Thunbergia } \\ \text { Ileuchera Sanguinea } & \text { Verbena }\end{array}$

\section{EVERIASTING FLOWERS}

Rhodanthe

Acroclinium

Gomphrena

Helichrysum

Ilonesty

Statice

Xeranthemun

\section{CLIMBING VINES, ANNUAI}

Balloon Vine

Scarlet Runner Bean

Canary Bird Vine

Cardinal Climber

Cypress Vine

Convolvulus, Morning Glory

Dolichos

Gourds, Ornamental

Humulus, or Japanese Hop

Ipomoea, all kinds

Mina Lobata

Momordica, Balsam Apple

Moonflower

Nasturtium, Tall

Sweet Peas

\section{CLIMBING VINES, PERENNIAT}

Ampelopsis, Boston Ivy

Australian Pea Vine

Cobea Scandens

Kudzu Vine

I,athyrus Latifolius

Smilax 


\section{SPECIALTIES}

(Cultural directions enclosed in colored packets)

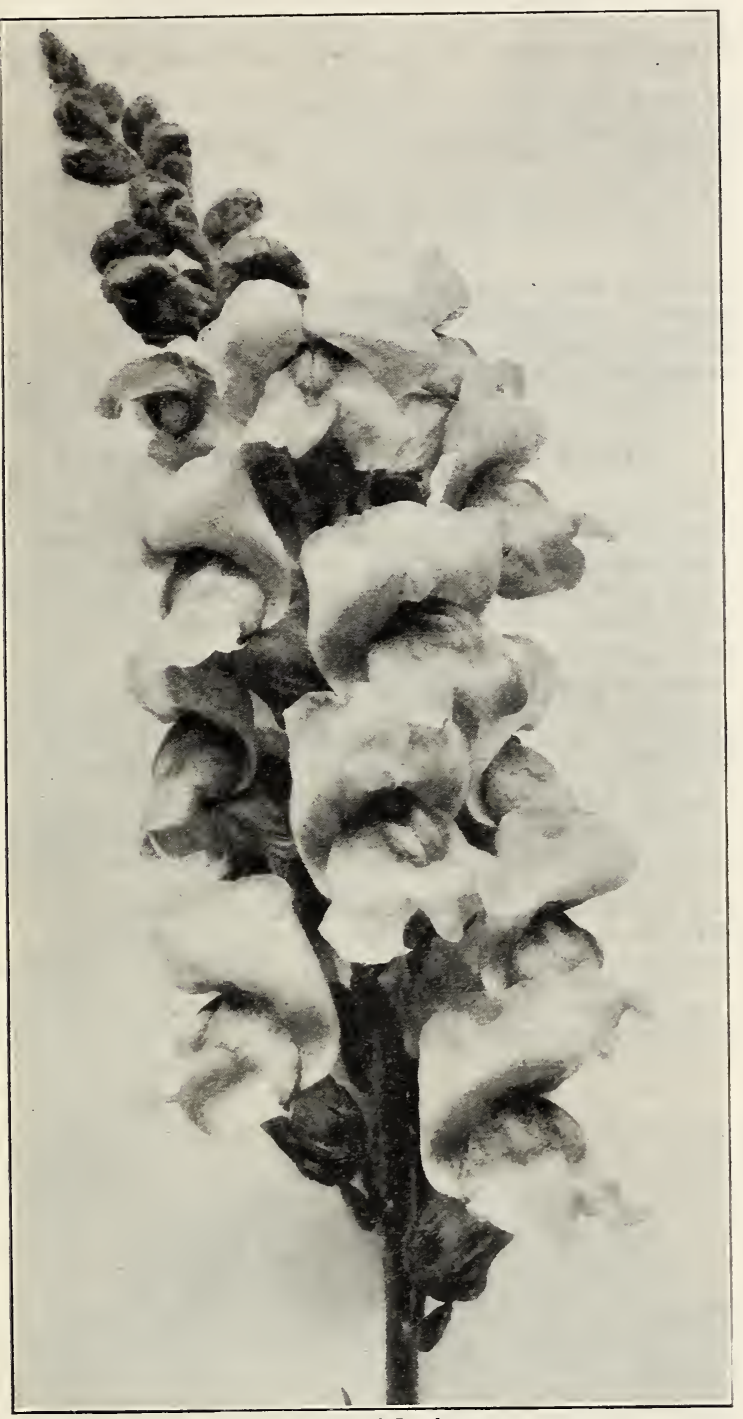

Snapdragon Maximum

\section{Snapdragon Maximum (Antirrhinum)}

This wonderful new group of Snapdragons surpasses anything ret introduced. In habit they are slightly taller than the Giant or Tall group. The flowers are of magnificent size closely placed on the spike. The group as a whole is slightly variable in size and color.

APPLE BLOSSOM-Rosy pink, white tube. Pkt., 15c.

CANARY BIRD-Canary-yellow. Pkt., $15 \mathrm{c}$.

COPPER KING-Bronzy Copper. Pkt., 15c

CRIMSON RING-Deep garnet. Pkt., 15c

OID GOID-Deep golden yellow. Pkt., 15c.

SID GOID-Deep golden yellow. Pk.

THE ROSE-Rose pink. Pkt., 15c.

Collection of the above 7 sorts for $85 \mathrm{c}$.

MAXIMUM-AII COIORS MIXID. Pkt., 15c.; I/4 oz., 65c.

\section{Sunshine Asters \\ (Improved Anemone Flowered)}

One of the most attractive norelties. The plants are sturdy and strong, throwing up long flower stalks, making wonderful cut flowers. Some of the flowers have twisted petals and some have quilled petals; all have a cushion center of tiny quills of a contrasting color which makes a flower look as if it were corered with snowflakes. The blue flowers are dotted with a paler blue and some with white. and the rose with a lighter shade of pink or white. Their delicate beauty is hard to describe.

BLUE, IILAC, PINR, WHITE, or MIXED-Pkt., 20c each.

\section{King Calendulas}

ORANGE KING, "Extra Select"-Very large, deep orange-red, with dark center. Pkt., 10c.; oz, $40 \mathrm{c}$.

IEMON KING, "Extra Select"-Very large, rich lemon-yellow. Pkt., 10c.; oz., $40 \mathrm{c}$.

THE BAII (Florist's Strain)-It has fine stems, large double flowers of a brilliant orange with light centers. The most desirable for forcing under glass. Pkt., $15 \mathrm{c.;} 1 / 4$ oz., $50 \mathrm{c}$.; oz., $\$ 1.50$.

\section{Carnation (Chabaud's Everblooming)}

This is one of the most satisfactory garden trpes, as thes bloom within a few months after being sown and continue to produce flowers in great profusion indefinitely. Sow the seed in boxes in the Fall or early Spring.

FLESH PINZ, WHITE, CRIMSON, ROSE PINK, CARDINAI RED and YELI.OW-Any of the above. Pkt., 15c.

Collection of one of each of the above 6 colors for $75 \mathrm{c}$. ChABAUD'S GIANT MIXED. Pkt., 15c.

\section{Columbine (Aquilegia)}

MRS. SCOTT FLIIOTT'S STRAIN-This strain is allowed by the Royal Horticultural Society to be the best ever raised. The blooms are of large size and the spurs very long. The colors range through shades of lavenders, maures, blues, purples, whites, creams, yellows, pinks, reds, etc. Pkt., 25c.; 5 pkts.,
$\$ 1.00$.

LONG SPURRED PINK FYBRIDS-A beautiful selection of pink and rose shades. Pkte, 25c.; 5 pkts., $\$ 1.00$.

\section{Delphinium or Perennial Larkspur} HOLIYHOCK OR WREXHAM STRAIN - A magnificent new race of perennial Larkspurs, producing spire-like spikes of bloom with many new and beautiful shades, ranging from pale blue to deep indigo-blue and royal purple, with many intermediate pastel tones of maure, pink, and lavender shadings. The flowers are very large and come in both single and double forms. For exhibition purposes they are unsurpassed. Pkt., 50c.

We offer the following especially selected strains. The plants are of strong, vigorous habit with large, handsome flower spikes.

IIGHT BLUE SHADES-Pkt., 20c.

DEEP BLUE SHADES-Pkt., $20 \mathrm{c}$.

PASTEL SHADES-Pkt., 20c.

Collection of one packet each of the above 3 shades for $50 \mathrm{c}$.

\section{Dianthus, Allwoodi}

(Perpetual-Flowering Hardy Pinks)

Our supply of this beautiful strain of Hardy Pinks comes to us direct from the introducer, a noted English specialist. It is expected that the seed will produce an average of 75 per cent double, deliciously clove-scented flowers in many colors. They are perfectly hardy and flower continually from Spring until late in the Autumn. Pkt. of 25 seeds for $35 c$. 


\section{SPECIALTIES}

\section{Giant Shirley Foxglove}

A new strain of giant Foxglove. The plant attains a height of 5 to 7 feet, with spikes 3 to 4 feet long carrying flowers of giant size, ranging in color from white to dark rose and handsomely blotched and spotted cream, maroon and chocolate. Pkt., 15c.

\section{Gaillardia, Portola Hybrids}

This superb new strain of perennial Gaillardia bears flowers of very large size, the color ranging through shades of bronzy red with the characteristic golden tipped petalage and robust vigor of the parent variety. A fine cut flower. Pkt., 25c.

\section{New Annual Larkspurs}

IA FRANCE-The large well formed double flowers are a pleasing salmon-pink and are well placed on long stems. Pkt., 25c.

EXQUISITE PINK IMPROVED-Beautiful soft pink, true to color and of greatly improved form. Pkt., 25c.

\section{Lilium Regale}

The Regal Lily. The flowers are white, slightly suffused with pink with a beautiful shade of canary-yellow at the center and extending part way up the long trumpet. It is delight fully perfumed and absolutely hardy. Blooms out of doors in July and seedling bulbs will flower the second rear. Lift the bulblets in the Fall and replant to greater depth in their permanent location. Pkt. of 50 seeds for $25 \mathrm{c}$. 5 pkts. for $\$ 1.00$.

\section{Improved African Marigolds}

Old favorite free flowering annuals with rich showy flowers, blooming all summer. Very effective in large beds or mixed borders and also splendid for eutting, owing to their good lasting qualities. 3 feet high.

ORANGE PRINCE-Immense double ball-shaped flowers of rich deep golden orange color. Pkt., 15c.; $1 / 4$ oz., 50c. LEMON QUEEN-Large ball-shaped flowers of a soft lemon yellow. Plt., 15c.; $1 / 4$ oz., $50 \mathrm{c}$.

\section{Iceland Poppies}

SUNBEAM IMPROVED-This strain includes many new tints such as maize, creams and various tones of rose. The Poppies are borne on long thick stems. Pkt., $25 \mathrm{c}$.

\section{Early Giant Imperial Stocks}

An especially fine strain of Summer Stocks. Growing from twenty-four to thirty inches tall; of branching habit. It is very free blooming and produces a high nercentage of double flowers. Splendid for cutting, but equally suitable for berlding.

CHAMOIS Ivory tinted old rose. Pkt., 15c.

DARK BLUE-Pkt., 15c.

FIERY BLOOD RED-Pkt., 15c.

FLESH-Delicate pink. Pkt., 15c.

GOLDEN BALI-Lirht canary yellow. Pkt., 15c.

LAVENDER Pkt., $15 \mathrm{C}$

ROSE-Deep rose pink. Pkt., 15c

WHITE-Pkt., $15 \mathrm{c}$. $75 \mathrm{c}$.

CHOICEST MIXED-Pkt., 15c.; 1/8 0z., 60c.

\section{Novelties in Imperial Stocks}

ANTIQUE COPPER Rich Hellebore-red overlaid with copper. Pkt., 25c.

GOLDEN ROSE-A rich light rose enhanced by a pleasing golden effect in the center of each individual floret. Pkt., 25 c.

\section{Three Improved Scabiosas}

AGERATUM BLUE-An attractive shade of blue, of very large size. Pkt., $15 \mathrm{c}$.

SHASTA-Mammoth pure white. Pkt., 15c.

PEACH BLOSSOM-Giant light pink. Pkt., 15c.

Collection of the above 3 varieties for $40 \mathrm{c}$.

\section{Giant Schizanthus}

(Poor Man's Orchid)

ROSE and PINK SHADES-Pkt., 25c.

ROSE and AMBER SHADES-Pkt., 25c.

MAUVE and PURPLE SHADES-Pkt., 25c.

GARRAWAY'S HYBRIDS-A remarkably fine strain, the flowers of which show an unusually wide range of colors. Pkt., 25c.

\section{Giant Dahlia Flowered Zinnias}

The plants of this new race are strong and of vigorous habit, fully three feet high, producing many flowers with stout stems, in a wide range of colors. The flowers in full bloom often measure four inclies in deptl and six to eight inches in diameter, closely resembling show dahlias.

BUTTERCUP-An immense deep canary yellow. Pkt., 20c. CRIMSON MONARCH-By far the largest and best of the red shades. Flowers often eight inches in diameter. Pkt., $20 \mathrm{c}$. DREAM-A fine deep lavender turning to purple. Pkt., 20c. EXQUISITE-Light rose with a deep rose center. A most pleasing color. Pkt., 20c.

GOIDEN STATE-A very rich orange-yellow. Yellow in the bud turning to an attractive orange when in full bloom. Pkt., 20c. LEMON BEAUTY-Immense flowers of a golden yellow or brown, decidedly a pastel shade. Pkt., 20c.

OLD ROSE-A real Old Rose shade. Pkt., 20c.

ORIOLE-Immense flowers of orange and gold. Pkt., 20c.

SCARLET FLAME-Bright scarlet with a blending of orange throughout the petals. Pkt., 20c.

Collection of 6 packets of any of the above varieties for $\$ 1.00$. HALLAWELL'S SPECIAL MIXTURE-A well blended mixture containing all the very best sorts. Pkt., $15 \mathrm{c}$.; $1 / 4$ oz., $60 \mathrm{c}$.

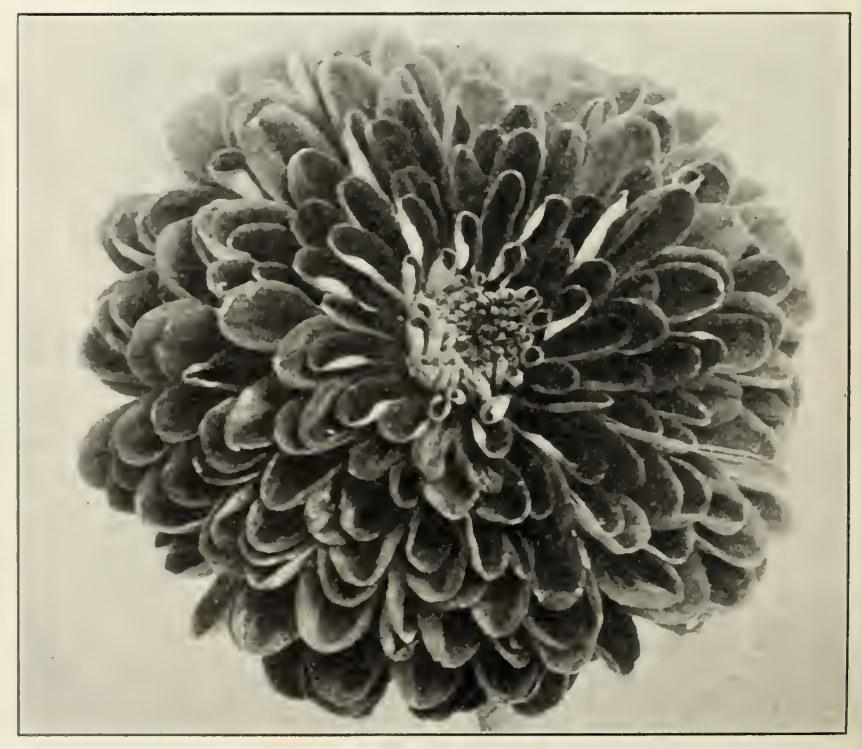

Zinnia Giant Dahlia Flowered 


\section{Abronia Grandiflora (Sand Verbena)}

A hardy annual trailing plant with numerous clusters of sweet scented rosy-lilac flowers. Thrives in dry situations and rockeries. Sow the seeds in the Fall or Spring, either in boxes to transplant or out of doors. Peel off the husk before sowing seed. Pkt., 10c.

\section{Abutilon (Flowering Maple)}

Beautiful shrubs with maple-like leaves and large bellshaped flowers in white, rose, yellow and red colors. Half hardy perennial. Sow the seed in boxes and transplant when well started, after danger of frost is over. Extra fine mixed, pkt., 15c.

\section{Achillea, The Pearl}

A fine hardy perennial, growing about 2 feet high, covered with heads of double white flowers throughout the entire season. Fine for cutting; will flower the first year if sown early. Sow in boxes to transplant. Pkt., 15c.

\section{Achimenes}

Profuse blooming greenhouse plants valuable for pots or hanging baskets. The flowers vary considerably in size and are of the most brilliant colors, 1 to 2 feet tall. Finest mixed, pkt., 50c.

\section{Acroclinium}

A pretty annual "Everlasting," growing about 15 inches high, bearing lovely white or rosy pink flowers, which, when cut in the bud state, can be dried and used in Winter bouquets. A nice thing to grow in a mixed border aside from its use as an everlasting. Sow seed from October till June in the open. Double pink, pkt., 10c; I/4 0z., 25c; oz., 75c.

\section{Ageratum (Floss Flower)}

A half hardy annual of easy culture, especially adapted for borders and bedding, as it is literally covered with clusters of feathery blossoms all Summer. Sow the seed early in Spring, either in boxes to transplant or out of doors, and thin to 4 or 6 inches apart.

SWANLEY BLUE-Fine for edging; 9 inches high. Pkt., 10c.; $1 / 4$ oz., 35c.

BLUF PERFECTION-Deep blue, 1 foot high. Pkt., 10c.; 1/4 oz., $35 \mathrm{c}$.

MEXICANUM IMPERIAT DWARF WHITE-Eight inches high; flowers white. Pkt., 10c.; $1 / 4$ oz., 35c.

LITTEE DORRIT-Deep blue. Six inches high and 1 foot through. Pkt., 10c.; $1 / 4$ oz., $35 \mathrm{c}$.

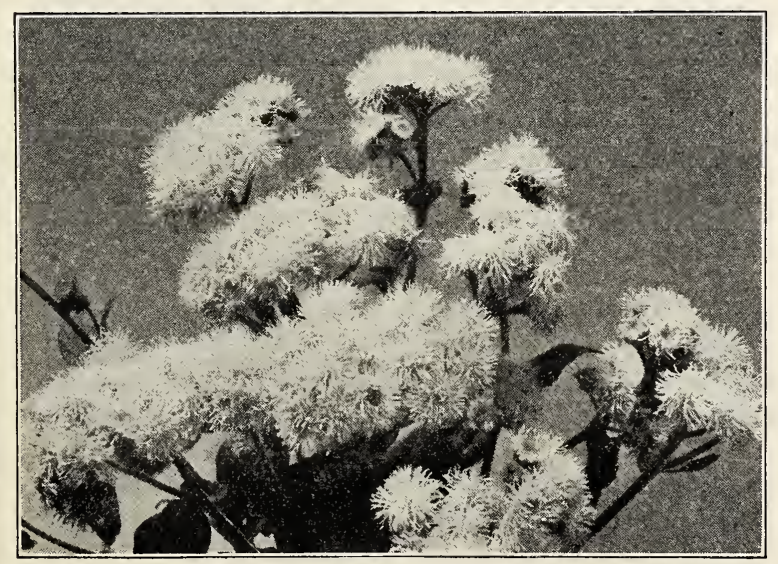

Ageratum

\section{Agathea Coelestis}

(Blue Daisy or Blue Marguerite)

Sky-blue flowers with yellow disc growing 1 foot tall. A half hardy perennial remaining in bloom all year round. Useful for window boxes. Sow the seed in boxes to transplant. Pkt., 10c; 1/4 oz., $60 \mathrm{c}$.

\section{Agrostemma Coronaria}

(Rose of Heaven or Mullein Pink)

An attractive free-flowering hardy perennial of easy culture, producing glowing crimson flowers like a single pink; has silvery-white foliage; 2 feet. Plant in the Fall or early Spring. Sow the seeds in boxes to transplant or out of doors. Pkt., 10c.

\section{Alonsoa Warscewiczi Compacta (Mask Flower)}

A charming variety of compact habit with racemes of bright vermilion-scarlet flowers; a free flowering, half hardy annual which grows 1 foot tall and thrives best in a sunny situation. Sow the seed in boxes in early Spring and transplant when danger from frost is over. Pkt., 15c.

\section{Alyssum}

For borders, edgings, and rockwork, we recommend a liberal use of this dainty little flower. In borders, sow thickly so as to form masses, early in Spring, or even the previous Autumn. For Winter bloom, sow late in August. Cut back after the first flowers fade, and others will come.

MARITIMUM (Sweet Alyssum) - Fragrant white flowers all Sum. mer. Hardy annual. Pkt., 10c.; oz., 35c.; $1 / 4$ lb., $\$ 1.00$.

MARITIMUM IITTIE GEM, Or CARPET OF SNOW-Dwarf and a very dense grower; fine for edgings; very floriferous. Hardy annual. Pkt., 10c.; $1 / 4$ oz., 25c.; oz., 75 c.

IILAC QUEEN-Flowers light lilac, well suited for bedding or ribbon bordering, the plants being erect and compact. rkt., $10 \mathrm{c}$; $1 / 4$ oz., $25 \mathrm{c}$.

SAXATIIE COMPACTUM (Gold Dust). - Single plants easily cover a square foot in a year, and produce many hundreds of bright yellow flowerheads. Grayish foliage. Hardy perennial. One foot. Pkt., 10c.; $1 / 4$ oz., 35 c.

\section{Amaranthus}

Remarkably handsome foliage and interesting flowers, producing a striking effect in the border as a background or as a center of beds. Seed may be sown in the open border, or in a hotbed; transplant about the first week in April. Produces the most attractive and brilliant foliage upon poor soil. Transplant to 20 inches. Half hardy annual.

CAUDATUS (Love Lies Bleeding-Long drooping scarlet flowers. Three feet. Pkt., 10c.

CRUENTUS-Tall spikes of red flowers. Three feet. Pkt., 10c.

SUNRISE-One of the most briliant annual foliage plants; very early in its growth, the top leaves become a fiery crimson, the lower ones, remaining maroon all summer. Pkt., 15c.

TRICOIOR SPLENDENS (Joseph's Coat)-Foliage scarlet crimson, yellow, and bronze green. Two feet. Pkt., 10c.

\section{Ampelopsis}

VEITCHI (Boston Ivy)-One of the most ornamental of climbing foliage plants, clinging closely without any assistance to a stone wall or wooden surface. In Autumn the leaves assume a reddish copper tint and are very effective. Pkt., 10c; oz., 50c.

\section{Anchusa}

ITALICA GRANDIFLORA (Dropmore Variety)-One of the best hardy perennials, growing about 5 feet high. The stems are covered all Summer with numerous wide star flowers of intense blue; should be in every hardy border. Pkt., 15c; r/4 oz., $40 \mathrm{c}$.

CAPENSIS (Cape Forget-Me-Not)-A hardy annual variety growing 2 feet tall, with azure blue flowers. Sow the seed in boxes in the Fall or Early Spring and transplant when well started. Pkt., 10c; I/4 0z., 25c, 


\section{Anagallis (Pimpernel)}

Lovely dwarf hardy annual plants, 6 inches high. Exreedingly ellective as edgings, also useful in rockeries. Sow the seed in the Fall or spring where it is to remain.

GRANDIFLORA BLUE-Pkt., 10c.; $1 / 4$ oz, 35c.

GRANDIFLORA MIXED-Nauve, blue and scarlet shades. Pkt., $10 \mathrm{c}$; it oz., $35 \mathrm{c}$.

ANTIRRHINUII-See Suapdragun.

AQUILEGIA - See Columbine.

\section{Anemone}

The fluwers conte in a great variety of colors. They bloom ery early in spring and make a nile display when planted son sed onteloors from April to Jume

CAIN or GIANT SINGLE-Mixed. Pkt., 10c.; 1/4 oz., 50c. SI. BRIGID - Mixture of semi-double and double flowers. True

\section{Arabis Alpina (Rock Cress)}

A hardy peremial Alpine trailing plant. Flowers are pure white and borne on erect spikes and bloom very early. l'stul in smmy rockeries and well-drained borders. Pkt., $10 c ; 1 / 4$ oz., 25 c.

\section{Arctotis (African Lilac Daisy)}

A remarkibly handsome amual from Afriea, forming lwancherl bushe: 2 to 212 feet in height and breadth; are pure white on the upper surface, reverse of petals pale lilate. sun the seed in the Fall or early spring, either in boxes to transplant or outside. Pkt., 10c; 1/4 0z., 30c.

\section{Asparagus}

PLUMOSUS t., 10c.; 100 seeds, 75c

SPREINGERI (Emerald Feather) - An easily grown, featheryPlit., 10c.; 100 seeds, 50c.

\section{Asters}

Asters are one of the most popular lialf hardy Summer and Fall flowering ammuls; excellent for bedding and cutting. Sow the serel in loxes from February to June and traisplant 1 foot apart each way when danger from frost is

SEMPLES or IATE BRANCHING-The plant grows 2 to 3 feet width. The blossoms are large, branches. Comes into flower late in the autumn. Iavezder, Blood Red, Pink or Rose, Purple, White, Light Blue, Mary Semple (very light pink)-Any oi the above, pkt., 10c.; $1 / 4$ oz., 50 c. Collection of one packet each above 7 colors, 60c. Mixture of all colors, 10c.; 1// oz., 50c.; oz., \$1.50.

CREGO GIANT - This fine variety grows over 2 feet tall and is sturdy growth. The fluffy, graceful White, Delicate Pink, Rose,
Whes Crimson, Lavender, Purple-Any of the above, pkt., 10c. Collection of one pscket each of above 6 colors, 50c. Mixture of ERARTS OF FRANCE-The best of the red Asters, the color

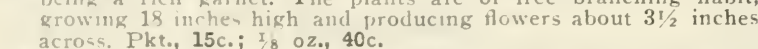
SINGLE or SOUTHCOTE BEAUTY - A distinct single type. Flowers are 2 to 3 inches in diameter with small yellow centers.

Rose Pink, White, Dark Blue, Light Blue, Mixed $\rightarrow$ Any of the pkt., 10c.

ASTERMUM - The largest flowering type of all asters with a chrysanthemum-1ke appearance. The plants grow 2 feet high with pkt., 10c. Mixtare of colors, pkt., 10c.; 1/4 oz., $60 \mathrm{c}$. SUNSHINE ASTERS-See specialty page 27.

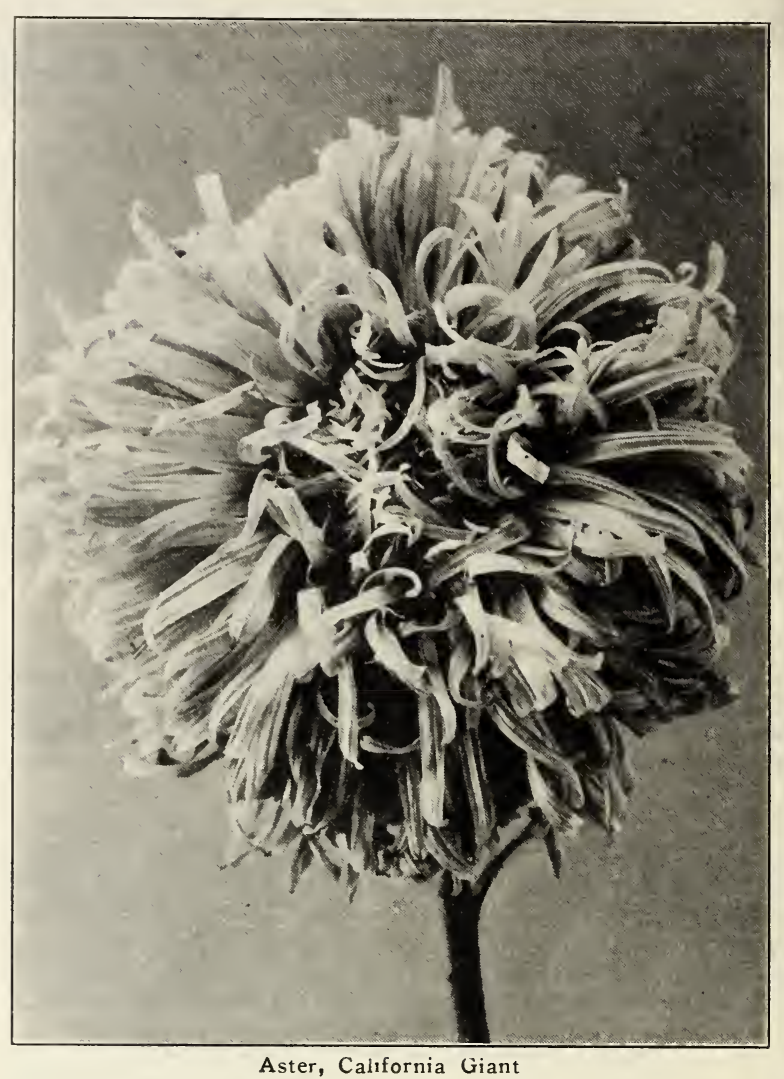

CALIFORNIA GIANTS-A splendid new strain of branching habit, plants grow 3 to $3 \frac{1}{2}$ feet high with long strong stems 18 to 24 inches in length bearing beautifully formed curled interlaced flowers 5 inches and over across. Deep Rose, Iight Blue, Peach Blossom, Dark Purple, White-Any of the above, pkt., 15c. Collection of one packet each of the above 5 sorts for $65 \mathrm{c}$. Mixture of all colors, pkt., $15 \mathrm{c}$.; $1 / 4$ oz., $75 \mathrm{c}$.

HALLAWELL'S GIANT COMET BRANCHING-Of fine branching habit, bearing immense flowers 5 inches across, the petals of which are gracefully twisted and are slightly broader than those of the Crego type. Valuable for cutting or for bedding. White, Rose, Lavender, Light Blue, Shell Pink, Royal Purple, Dark Blue, Crimson-Any of the above, pkt., 15c. Co!lection of ore packet each of the above 8 sorts for $\$ 1.00$. Mixture of all colors, pkt., 15c.; $1 / 4$ oz., $75 \mathrm{c}$.

IATE BEAUTY_A comparatively new type of Aster which comes into bloom early in September and lasts until late in the Fall. The straight petaled flowers are large and densely double and borne on'long and stout stems from 18 to 24 inches. Azure Fairy (light blue), Crimson Beauty, Peach Blossom (delicate pink), Purple Beauty, Rose Beauty, White Beauty-Any of the above, pkt., 15c. Collection of one packet each of the above 6 sorts for $75 \mathrm{c}$. Mixture of all colors, pkt., 15c.; $1 / 4$ oz., $75 \mathrm{c}$.

\section{Aster Perennial}

(Michaelmas Daisies)

Beautiful hardy Fall flowering peremnials, growing 2 to 5 feet tall; single flowers in shades of lilac, blue and mauve. GOLIATH_Flowers beautiful lilac with golden disc. Pkt., 15c. NEW LARGE FLOWERED-Mixed, pkt., 15c.; 1/8 oz., $50 \mathrm{c}$.

\section{Aubrietia Graeca}

A rery dwarf hardy purple perennial suitable for rockeries or Spring bedding. Sow the seed in the Summer or Fall. Pkt., 15c; $1 / 8$ 0z., 50c. 


\section{Australian Pea Vine \\ (Dolichos Lignosus)}

A rapid-growing evergreen climbing perennial, flowering freely in large clusters of rose flowers. For covering arbo:s, trellises, etc., they have no superior. Pkt., $10 \mathrm{c}$; I/4 oz., $30 \mathrm{c}$.

\section{Balloon Vine (Love-in-a-Puff)}

A rapid-growing annual climber, 10 feet high; succeeds best in light soil and warm situations; flowers white; seed vessels look like miniature balloons. Sow seed in the open ground in March or April. Pkt., 10c; oz., 25c.

\section{Balsam or Lady's Slipper}

A tender annual, with brittle stems and foliage. Grows about 12 inches high. Plants are profusely covered with large double wax-like flowers of brilliant colors-some selfcolored, others blotched, spotted, and striped in a wonderful manner. Sow the seed in Spring in boxes to transplant or out of doors when danger of frost is over. Set the plants 18 inches apart.

DOUBLE WHITE-Pkt., 10c.

SAIIION KING-Salmon-pink, very double. Pkt., 10c.

DOUBLE IILAC-Pkt, 10c.

DOUBLE PURE SCARLET-Pkt., 10c.

DOUBLE VIOLET-Pkt., 10c.

CAMELIIA FLOWERED MIXED-Resembles a Camellia in its perfect shape. Pkt., 10c.; I/4 oz., 25c.; oz., 75c.

ROSE FIOWERED IIIXD-Of beautiful colors, flowers, large, double. Pkt., 10c.; 1/4 oz., 25c.; oz., 75c.

\section{Bartonia Aurea}

A California wild flower producing showy golden-yellow flowers above its gray and downy thistle-like foliage, which is exceedingly brilliant in the sunshine. Sow it where it is to remain, as it does not bear transplanting; annual; 2 feet. Sow in the Fall or Spring. Pkt., 10c; oz., 60c.

BACHELOR BUTTONS-See Centaurea Cyanus.

BELIIS PERENNIS-See Daisy.

\section{Begonia, Tuberous-Rooted}

Plants of great value for pot culture or for growing outside in a sheltered position, blooming the first season from seed, if sown in February or March, in a temperature of 60 degrees. To secure the best results for outdoor planting, they should be set out as soon as the ground becomes warm. They are covered the whole Summer with bright and elegant flowers. (For bulbs, see page 76 ).

SINGIE-International Prize Mixed. Pkt., 35c.

DOUBLE_Extra choice mixed. Pkt., 50c.

CRISPA MIXED-Large single flowers, beautifully frilled on edge and crested. Pkt., $35 \mathrm{c}$.

LIOYDI-Owing to its pendulous habit this Begonia makes a beautiful pot plant, but a still more striking effect is produced in hanging baskets. The flowers are double and come in many fine shades. Pkt., 50c.

\section{FIBROUS ROOTED VARIETIES}

These dwarf varieties are valuable for bedding, doing equally well in full sunlight or in partially shaded positions. They flower from May until frost. One foot. Half hardy perennials.

ERFORDIA-Delicate rosy carmine. Pkt., 25c.

PRIMA DONNA-Light rose, deeper at center. Pkt., 25c.

LUMINOSA-Deep scarlet, foliage crimson-bronze. Pkt., 25c.

SAIMON QUEEN - Brilliant salmon-rose, foliage brownish-red. Pkt., 25c.

VERNON-Scarlet, foliage bronze-red. Pkt., 15c.

\section{Brachycome (Swan River Daisy)}

Free flowering dwarf growing hardy annuals, covered during the Summer with a profusion of pretty blue flowers. Blue shades mixed. Pkt., 10c; $1 / 4$ oz., $40 \mathrm{c}$.

\section{Browallia (Amethyst)}

FLATA BLUE_Very free-flowering, half hardy annual, covered with large blue flowers. Used both for bedding and cutting;
height 18 inches. Pkt., 10c.; I/4 oz., $30 \mathrm{c}$.

SPECIOSA MAJOR_Extra large deep blue; does finely out:ide in the border, but is especially valuable as a pot plant fre

\section{Calceolaria}

A tender annual, used largely in greenhouses and conservatories. Is not of easy culture, but a rely desirable flower. Bears a large profusion of large, pocket-shapel flowers, many of which are beautifully tigered or spotted. There is a great variety of shades and colors in various markings.

COVENT GARDEN STRAIN-Flowers of large size and beatifully marked in a great variety of colors. Pkt., 50c.

\section{Calendula (Cape Marigold)}

For effective and persistent blooming in beds and groups. the newer varieties of the common Marigold have no supe $i$ ors, their beautiful flowers baing produced from early Spring until late in the Fall. Sow in the open and thin 0 : transplant to 1 foot apart; sow in January, May and August for a succession of blooms.

ORANGE KING ("Extra Select") -Very

with dark center. Pkt., 10c.; oz., 40c.

IEMON KING ("Extra Select")-Very large, rich lenon-yellow Pkt., 10c.; oz., 40c.

JAUNE VIF-Cadmium orange, light eye. Pkt., 10c.; oz., E0c. METEOR-Creamy white, striped orange. Pkt., 10c; oz., 30c. NANKEEN-Cream flushed lightly with apricot, distinct. Pkt., 10c.; oz., 30c.

TRIANON-Lemon yellow, striped orange, dark eye. Pkt., 10c.; oz., 30c.

Collection of one packet each of the above 6 sorts, $50 \mathrm{c}$.

MIXED ALI COLORS-Pkt., 10c.; oz., 25c.; 1/4 1b., $75 \mathrm{c}$.

THE BAII (Florist's Strain)-It has fine stems, large double flowers of a brilliant orange with light centers. The most desirable for forcing under glass. Pkt., 15c.; 1/4 oz., 50c.; oz., $\$ 1.50$.

CAIIFORNIA POPPY_See Eschscholtzia.

\section{Calliopsis}

Showy and beautiful free-flowering annuals, of the easiest culture, doing well in any sunny position, blooming all Summer and excellent for cutting and massing. It is best to sow them where they are to bloom, in Spring; thimning out to stand 6 inches to 12 inches apart.

ATROSANGUINEA-Velvety dark maroon. Pkt., 10c.; $1 / 4$ oz., 25c.; Oz., 75c.

BI-COIOR HYBRIDA SFMI PLENA-Semi-double flowers of garnet and yellow. Pkt., 10c.; $1 / 4$ oz., $25 \mathrm{c}$.

CRIMSON IKING-A fine dwarf sort 9 inches high; color, rich velvety crimson-scarlet. Pkt., 10c; $1 / 4$ oz., 25c.

GOIDEN WAVE-The largest flowering variety. Clear yellow with brown centers produced in great abundance. Pkt, 10c.; $1 / 4$ oz., $25 \mathrm{c}$.

TIGER STAR-Dwarf variety, not over 9 inches high. Flowers a rich reddish-brown tigered with golden-yellow. Pkt., 10c.; $1 / 4$ oz., $25 \mathrm{c}$.

DRUMMONDI MIXED-A gorgeous mixture of golden yellow, brown, maroon and other shades. Pkt., 10c.; I/2 oz., 20c.; oz., $35 \mathrm{c}$.

Collection of one packet each of the above 6 sorts, $50 \mathrm{c}$. For perennial sorts see Coreopsis.

\section{Canna-Indian Shot}

One of the finest tall bedding plants with large ornamental leaves and long flower stalks. Soak the seeds in warm water until they show evidence of swelling, then sow in sandy loam, and place in a hotbed; when up to the second leaf, pot off singly and keep under glass until the proper season for planting out.

CROZY'S VARIFTIES, MIXED_New large flowering and free blooming sorts. Plit., 10c.; oz., $40 \mathrm{c}$. 


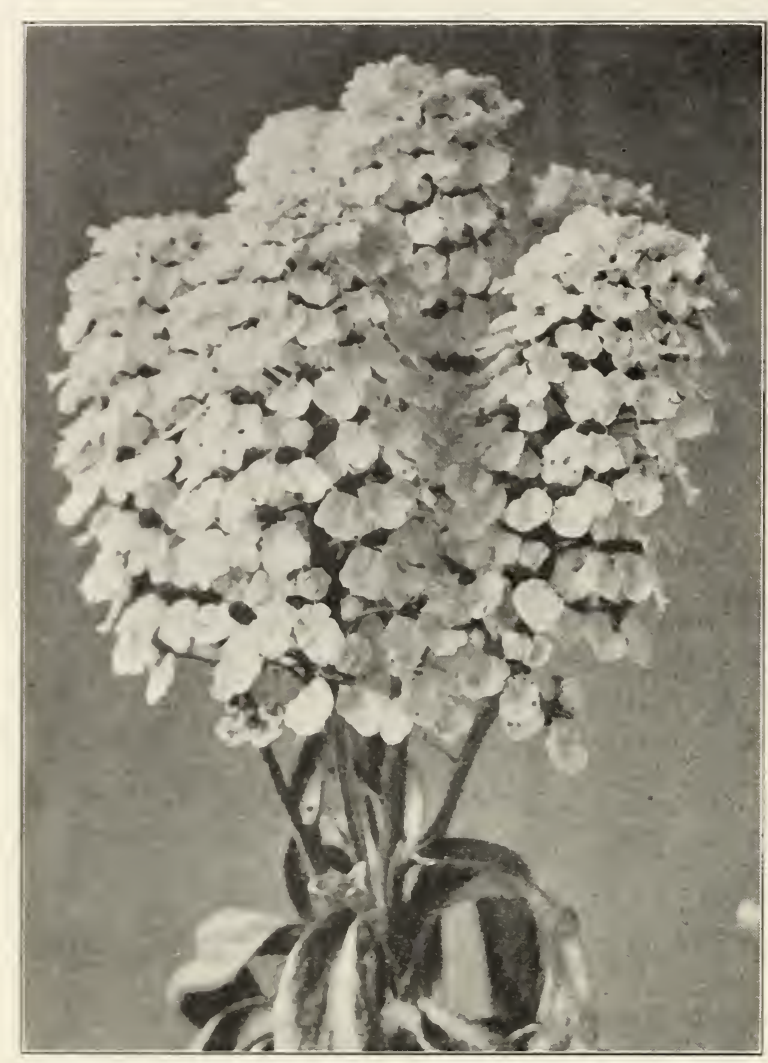

Candytuft Giant Hyacinth Flowered

\section{Candytuft-Annual Sorts}

A hardy annual, growing about 6 to 18 inches high, according to the variety. The blossoms are borne on various long spikes. Universally cultivated, and considered indispensable for cutting. All the varieties look best in beds or masses; seeds sown in Autumn produce flowers early in Spring; when sown in April, flowers from July to September, and some of the sorts till frost comes. All the varieties are hardy and easy to cultivate. Perennial sorts should be started in boxes and transplanted later.

ALBIDA-Creamy white. Pkt., 10c.; oz., 50c.

GIANT HYACINTH FLOWERED, OT IMPROVED EMPRESS -Very large heads and long spikes of white flowers. Best sort
for cut flowers. Extra select strain. Pkt., 10c.; $1 / 4$ oz., 25c.; for cut
oz., $75 \mathrm{c}$.

CARMINE-Bright carmine rose. Pkt., 10c.; oz., 50c.

CRIMSON or PURPLE-Pkt., 10c.; oz., 50c.

LAVENDER-Delicate shade of lilac. Pkt., 10c.; oz., 50c.

ROSE CARDINAL-A new and striking color, deep rosy cardinal. Pkt., 10c.; oz., 50c.

Collection of a packet each of the above 6 sorts, $50 \mathrm{c}$. SPLENDID MIXED-Pkt., 10c.; 1/2 oz., 25c.; oz., $40 \mathrm{c}$. DWARF LAVENDER-Pkt., 10c.; $3 / 4$ oz., 40c. DWARF PINK-Pkt., 10c.; $1 / 4$ Oz., $40 \mathrm{c}$.

DWARF HYBRIDS MXED-Plants of fine compact growth in a large range of colors. Sow in late Spring or Summer as the
plants will grow tall if the seed is sown earlier. Pkt., 10c.; $1 / 4$ oz., 25c.; oz., 75c.

\section{Candytuft-Perennial Sorts}

SEMPERVIRENS-Pure white. Pkt., 15c.; 1/8 oz., 50c. GIBRALTARICA_White shading to lilac. Pkt., 10c.; $1 / 8$ oz., 35c.

\section{Campanula}

Well known, beautiful hardy herbaceous perennials and biennials, bearing a great profusion of attractive bellshaped flowers, thriving best in light, rich soil; some of the varieties flower the first season if sown early. Sow the seed of Canterbury Bells from April 15th until June to bloom the following Summer. Sow the seeds of all varieties in boxes and transplant when well started to one foot apart.

CANTERBURY BELIS (Campanula Medium) -A hardy biennial, blooming the second year from seed; of easy culture, but preferring rich, moist soil. Grows about 3 feet high and bears single bell-shaped flowers in blue, white, purple and pink colors. Dark Blue, White, Rose, Lavender. Any of the above colors, pkt., 10c.; $1 / 4$ oz., $35 \mathrm{c}$.

Finest single mixed, pkt., 10c.; $1 / 4$ oz., 25c.; oz., 75c.

DOUBLE MIXED_All the double flowering varieties assorted. Pkt., 10c.; $1 / 4$ oz., 50c.

CUP and SAUCER TYPE-In this variety the outer petals form a brim, like a saucer. Dark Blue, pkt., 15c.; White. pkt., 15c.; Rose, pkt., 15c.; Lavender, pkt., 15c. Finest Mixed, pkt., 10c.; $1 / 4$ oz., 65 c.

ANNUAI CANTERBURY BELIS-A new strain of these beautiful flowers which will commence blooming in August or September if the seed is sown in January or February. Sow the seed in boxes and transplant when well started to 1 foot apart. Dark Blue, pkt., 15c.; Rose Pink, pkt., 15c.

PERSICIFOLIA GRANDIFIORA (Peach-bell) - Perennial : 4 feet; large flowered. Mixed, pkt., 15c.; Blue, pkt., 15c.; White, pkt., $15 \mathrm{c}$.

PYRAMIDALIS-Chimney Bellflower. Large flowers on tall (6foot) spikes; blooms late; perennial. Blue, pkt., 10c.; White, pkt., 10c.; Mixed, pkt., 10c.

CARPATICA (Carpathian Farebell)-A dwarf perennial; 9 inches; for rockeries, edges and beds. Blue, pkt., 10c.; White,pkt., 10c.; Mixed, pkt., $10 \mathrm{c}$.

\section{Canary Bird Flower \\ (Tropaeolum Canariense)}

A tender, climbing annual of the Nasturtium family. Blossoms have curiously winged petals and are light yellow. Sow the seed in the open ground from March 15th until June. Pkt., 10c; oz., 40c.

CARDINAI CLIMBER-See Cypress Vine.

\section{Carnation}

The Marguerite and Chabaud Carnations are the most satisfactory garden types as they bloom within a few months after being sown and continue to produce flowers in great profusion indefinitely. Sow the seed in boxes in the Fall or early Spring. The florists' varieties are propagated from cuttings.

CHABAUD'S EVERBLOOMING-Very free blooming, produces a large percentage of double flowers, Flesh Pink, White, pkt., $15 \mathrm{c}$. Collection of one packet each of the above 6 colors, 75 c.

CHABAUD'S GIANT MIXED-Pkt., 15c.

MARGUERITE-A very vigorous early blooming type. The flowers are prettily fringed and very fragrant and are borne in great profusion on long, strong stems. Mixed colors, pkt., 10c.; $1 / 4$ oz., $40 \mathrm{c}$.

GIANT MARGUERITE-An improved strain producing larger flowers often measuring $2 \frac{1}{2}$ to 3 inches across. Mixed colors, pkt., $15 \mathrm{c} . ; 2 / 4$ oz., $60 \mathrm{c}$.

PICOTEE-Finest double strain, ground is white edged with colors, or striped and splashed, contains many rare sorts. Flowers the second season. Pkt., 25c.

\section{Castor Oil Bean (Ricinus)}

A half hardy perennial with large ornamental foliage, growing from 6 to 15 feet high. Sow the seed from March until June.

ZANZIBARENSIS-Mixed. A large-leaved variety, deep green and bronze growing 10 to 15 feet high. Pkt., 10c.; oz., 25c.

GIBSONII-Large dark leaves of metallic luster. Pkt., 10c.; oz., $25 \mathrm{c}$.

MIXTURE OF AIL VARIETIES-Pkt., 10c.; oz., 20c. 


\section{Celosia (Cockscomb)}

Very attractive and showy annual, producing massive heads of rich shades of crimson and yellow flowers. Does best started in a hotbed and transplanted into very rich soil after warm weather has set in. Set the plants a foot or more apart. Tender annuals.

PLUMOSIS, or FEATHERED COCKSCOMB-This species grows 2 or 3 feet high, and bears long, feathery plumes in brilliant colors. Mixed. Pkt., 10c.; 1/4 oz., 25c.

PLOMOSA MAGNIFICA-A new variety, superior to the older sorts of pyramidal growth attaining a height of 3 feet and producing feathery plumes of the most brilliant colors. Mixed. Pkt., 10c.; $1 / 4$ oz., 50c.

PLUMOSA MAGNIFICA, YFLLOW-Pkt., 10c.; $1 / 4$ oz., $60 \mathrm{c}$. PIUMOSA MAGNIFICA, CRIMSON-Pkt., 10c.; $1 / 4 \mathrm{oz.,} \mathrm{60c.}$ PIUMOSA MAGNIFICA, SCARLET-Pkt., 10c.; $1 / 4$ oz., $60 \mathrm{c}$. PRIDE OF CASTLE GOULD-Beautiful plants for pot culture or for bedding, of pyramidal compact habit, attaining a height of 2 to 3 feet, with immense fine feathered heads, in wide range of colors. Prize strain. Pkt., 35c.

CHIIDSI or CHINESE WOOLFLOWER-This attractive variety grows 2 to 3 feet high, bearing on long stems brilliant flowers that look like balls of silky wool; very effective in the garden. Crimson and Yellow, each 15c. per pkt.; 1/4 oz., 60c.

CRISTATA GLASGOW PRIZE-A dwarf crimson variety, 6 or 8 inches high, with very wide combs. Valuable for borders and edging. Pkt., 10c.

GIANT EMPRESS-Wide blood-red combs, brown foliage, dwarf, Pkt., 10c.

DWARE YELLOW-Pkt., 10c.

DWARF MIXED-Pkt., 10c.

\section{Celsia Arcturus}

A splendid half hardy greenhouse plant with fine long spikes of bright yellow flowers. It is easily raised from seed and if sown in Spring the plants will bloom the same sea son. Pkt., 35c.

\section{Centaurea Cyanus}

(Bachelor Button or Cornflower)

Oi easy culture, sow the seed either in the Fall or Spring in boxes to transplant or sow where the plants are to remain and thin to 4 inches.

SINGLE BLUE-The old fashioned sort. Pkt., 10c.; oz., 40c. DOUBLE BLUE-Large semi-double blue flowers; plants of vigor-

ous growth. Pkt., 10c.; 1/4 oz., 25c

DOUBLE PINK-Clear rose-pink. Pkt., 10c.; 1/4 oz., 25c.

DOUBLE WHITE-Pure white. Pkt., 10c.; 1/4 oz., 25c.

DOUBLE MAROON-Pkt., 10c.; $1 / 4$ oz., 25c.

DOUBLE MAUVE-Pkt., 10c.; $1 / 4$ oz., 25c.

DOUBLE ROSY RED-Pkt., 10c.; $1 / 4$ OZ., 25c.

Collection of one packet each of the above 6 double sorts, $50 \mathrm{c}$. DOUBLE MIXED, All Colors-Pkt., 10c.; oz., 50c.

\section{Centaurea Imperialis}

(Royal Sweet Sultan)

The large thistle-like blossoms are borne on long strong stems; when cut will last in good condition for several days; 3 feet tall. Sow in the Fall or early Spring so that they may perfect their flowers before very hot weather comes.

PURE WHITE, pkt., 10c.; ROSE, pkt., 10c.; PURPLE, pkt.,

10c.; LAVENDER, pkt., 10c.; AMIARANTH RED, pkt., 10c. ANY OF THE ABOVE COLORS, 1/4 Oz., 30c.

MIXED COLORS, pkt., 10c.; $1 / 4$ oz., $25 \mathrm{c}$.

CENTAUREA SUAVEOLENS-Yellow Sweet Sultan. Pkt., 10c.; $1 / 4$ oz., 30c.

CENTAUREA AMERICANA-A splendid native annual variety; grows 3 feet high and bears immense thistle-like blooms of rosy lavender color. Pkt., 10c.

CENTAUREA MONTANA (Perennial Cornflower)-Hardy perennial sort, growing 2 feet high, bearing large violet-blue flowers during July and August. Pkt., 10c.

CENTAUREA CANDIDISSIMA, WFITE IEAVFD, or DUSTY MIILER-Grown for its silvery white foliage; used for borders, carpet bedding; 1 foot; perennial. Pkt., 10c.; 1/4 oz., 65 c.

CENTAUREA GYMNOCARPA-Foliage finely cut, of silvery gray color, perennial, $11 / 2$ feet. Pkt., 10c.; $1 / 4$ oz., 35 c.

\section{Cerastium (Snow in Summer)}

TOMENTOSUM-Very pretty dwarf white leaved plant, bearing small white flowers; invaluable for rockeries and edgings; hardy perennial. Start in boxes to transplant. Pkt., 15c.

\section{Chrysanthemum}

(Annual Varieties)

Summer-blooming annuals, of compact growth, producing quantities of large single flowers, 2 inches across, and of striking beauty. Colors, crimson, gold, maroon, white, etc.; very effective for flower beds and for cut flowers. 2 to $2 \mathrm{I} / 2$ feet. Sow the seed in Spring where it is to remain and thin to about 6 inches apart.

BURRIDGEANUM-White with crimson ring. Pkt., 10c.; $1 / 4$ oz., $25 \mathrm{c}$.

CHAMEION-Golden chamois with scarlet zone. Pkt., 10c.; $\mathrm{I} / 4$ oz., $25 \mathrm{c}$.

PURPUREUM-Purple flowers varying slightly in shade. Pkt., 10c.; $1 / 4$ oz., 25c

SINGIE IMIXED-All Colors. Pkt., 10c.; I/4 oz., 20c.; oz., 50c.

CARINATUM DOUBIE MIXED-The flowers come in a great variety of colors and are fine for cutting. This type is far superior to the Coronarium and should be extensively planted. Pkt., 10c.; $1 / 4$ oz., 25c.; oz., 75c.

EVENING STAR (Annual Golden Marguerite) - A splendid variety for cutting. Pure golden yellow; giant single flower, 3 inches in diameter. Pkt., 10c.; $1 / 4$ oz., $25 \mathrm{c}$.

MORNING STAR-Large, primrose-yellow; single flower shading deeper; fine for cutting. Pkt., 10c.; I/4 oz., 25c.

FASTERN STAR-Primrose yellow with brown disc; very fine. Pkt., 10c.; $1 / 4$ oz., 25c.

NORTHERN' STAR-Large, pure white with yellow center and dark disc. Pkt., 10c.; 1/4 oz., 25c.

MAXIMUM, KING EDWARD (Moonpenny Daisy)-A perennial variety. The flowers are exceedingly large, pure white and of splendid form. Free flowering and valuable as a cut flower. Pkt., 10c.

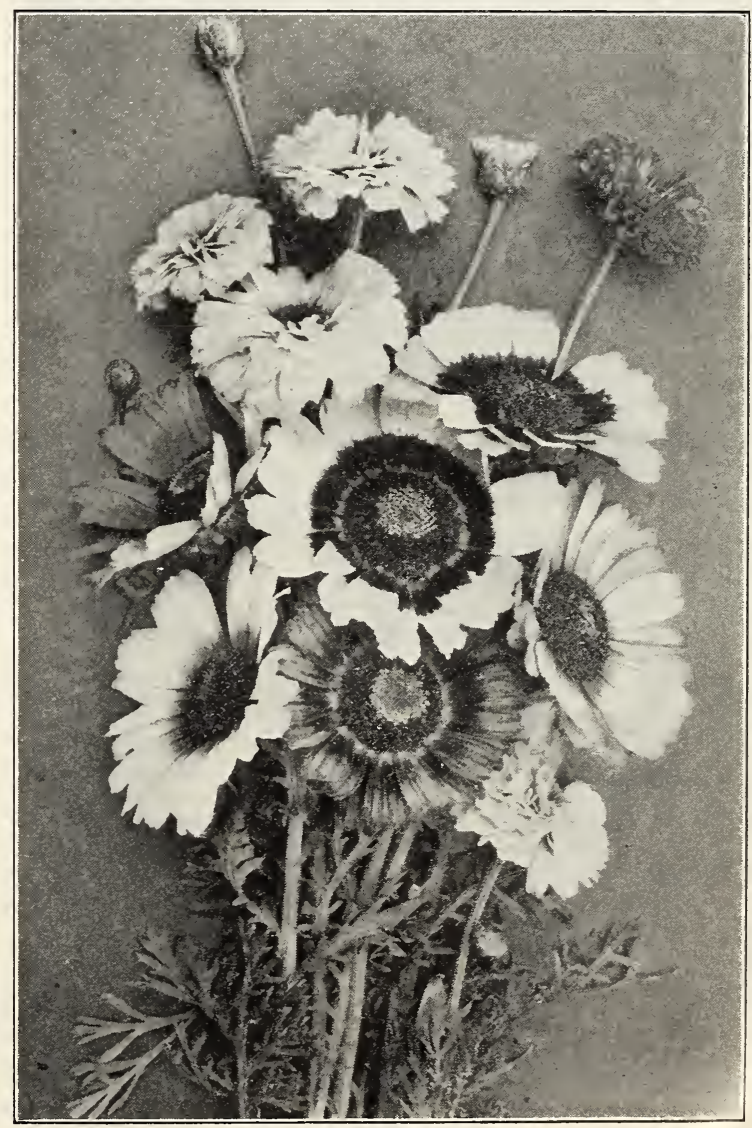

Annual Chrysanthemums 


\section{Cheiranthus Allionii}

A splendid lardy peremial growing from 9 to 12 inches tall. producing Walltlower-like flowers of the most brilliant orange-rellow throngliont the spring and summer. Will blowm the first season if sown early. Start in boves to transplant. Pkt., 10c; $1 / 4$ oz., 35c.

\section{Chelone Barbatus Torreyi}

A hardy perennial with long coral-red spikes like a Pentstenon. Blooms during July and August. Pkt., 10c.

\section{Clarkia}

A liardy annulal of easy culture, growing about 18 inclies high and bearing bright rose, white, or purple flowers in great profusion. Feed sown in the Fall will give early blossuns in the spring. Seed can be sown almost any time.

PURPIE PRINCE-Fine double purple. Pkt., 10c.; 1/4 oz., 35c. QUEEN MARY-Double rose carmine, very bright color. Pkt., 10c.; $1 / 4$ oz., 35c.

SAIMON QUEEN-Double salmon pink flowers. Pkt., 10c.; $1 / 4$ oz., $35 \mathrm{c}$.

SCARLET BEAUTY-Double brilliant scarlet. Pkt., 10c.; 1/4 oz., $35 \mathrm{c}$. DOUBLE MIXED-Pkt., 10c.; 1/4 oz., 25c.; oz., 75 c.

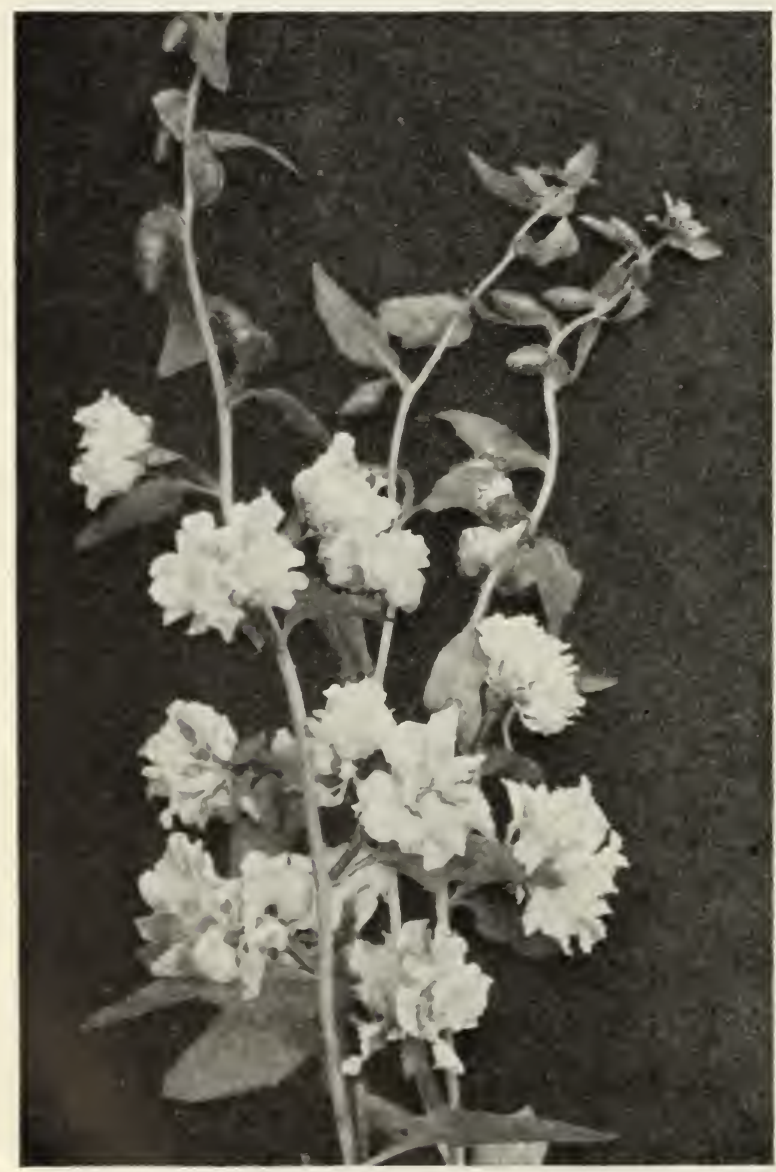

Clarkia

\section{Cineraria}

These plants are invaluable for the decoration of the conservatory or for bedding outside in partial shade; unsurpassed for riclmess and variety of vivid colors, ranging throngh all shades of blue, purple and crimson; the seed is easily started and the plants grow readily in good ordinary soil. Sow in boxes in the Summer for Spring blooming, or early in Spring for late Summer flowering.

CINERARIA, HALLAWELL'S PRIZE-Extra large flowers in

rich and vivid colors ranging through all shades of blue, pur-

ple, crimson, scarlet and pink, compact habit. Pkt., 35c.

HALLAWELL'S DWARF PRIZE-Dwarf compact plants, not over a foot high. Pkt., 35c.

GOOD MIXTURE of large flowered sorts. Pkt., 25c.

ROYAL BLUE-Pkt., 50c.

ROSE-Pkt., 50c.

MATADOR-Terra-cotta red. Pkt., 50c.

SKY BLUE_-Pkt., 50c.

STELLATA (Star-Flowering Cineraria) - A tall-growing variety

with large, spreading panicles of star-shaped flowers in all colors. Pkt., $25 \mathrm{c}$.

\section{Cleome Pungens \\ (Giant Spider Plant)}

The plants grow 3 to 4 feet tall and are well branched, with head of curious-shaped rose colored flowers. Used extensively in the nixed border and among slirubbery. Sow seed in the open when the ground becomes warm. Pkt., 10c,

\section{Cobaea Scandens}

A very fine and rapid-growing climber, witl large bellshaped purple flowers and beautiful foliage. Needs rich soil; plant the seeds edgewise and cover lightly. Pkt., 10c.

\section{Coleus}

Plants with richly colored foliage of nuaroon, green, crimson, yellow, etc. For groups on lawns and ribboning they are indispensable, and also valuable for pot culture. Although peremnials, ther attain perfection from seed the first season. 1 to 3 feet.

HALLAWELI'S IMPROVED HYBRIDS-This strain produces

the finest colored and most attractive varieties. Pkt., $35 \mathrm{c}$. RAINBOW MIXTURE-Pkt., 15c.

\section{Collinsia Bicolor}

A free-flowering and easily grown ammul, growing from 1 to 2 feet; flowers violet and white. A California wild Hower; prefer's shade. Pkt., 10c; oz., 30c.

\section{Coreopsis}

A perennial with light, graceful foliage and beautiful golden flowers. Blossons in midsmmmer and is one of the best yellow cut flowers. Sow the seed in boxes and transplant to 1 foot apart.

GRANDIFLORA-Pkt., 10c.; $1 / 4$ oz., $25 \mathrm{c}$.

GRANDIFLORA FLORA PLENA-This new semi-double form is

just as easy to grow as the single flowering and the extra

petalage adds a further charm to the flower. Pkt., 15c.; $1 / 4$ oż., $50 \mathrm{c}$.

\section{Cyclamen}

A tender bulbous perennial, used in greenhouses and window gardens. It is easily grown from seed. Sow in the Fall or early spring.

PERSiCUM GIGANTEUM-White, Pkt., 10 seeds, 25c.

PERSICUM GIGANTEUM-White, carmine red eye. Pkt., 10 seeds, 25c.

PERICUM GIGANTEUM-Light rose, dark red eye. Pkt., 10 seeds, 25c.

PERSICUM GIGANTEUM-Red, Pkt., 10 seeds, 25c.

PERSICUM GIGANTEUM-New Salmon, Pkt., 10 seeds, 25c.

PERSICUM GIGANTEUM-Mixed pkt., 15 seeds, 25c.; 100 seeds, $\$ 1.50$.

PAPILIO-Butterfly type, fringed and waved edges. Pkt., 12 seeds, 25c.; 100 seeds, \$1.75. 


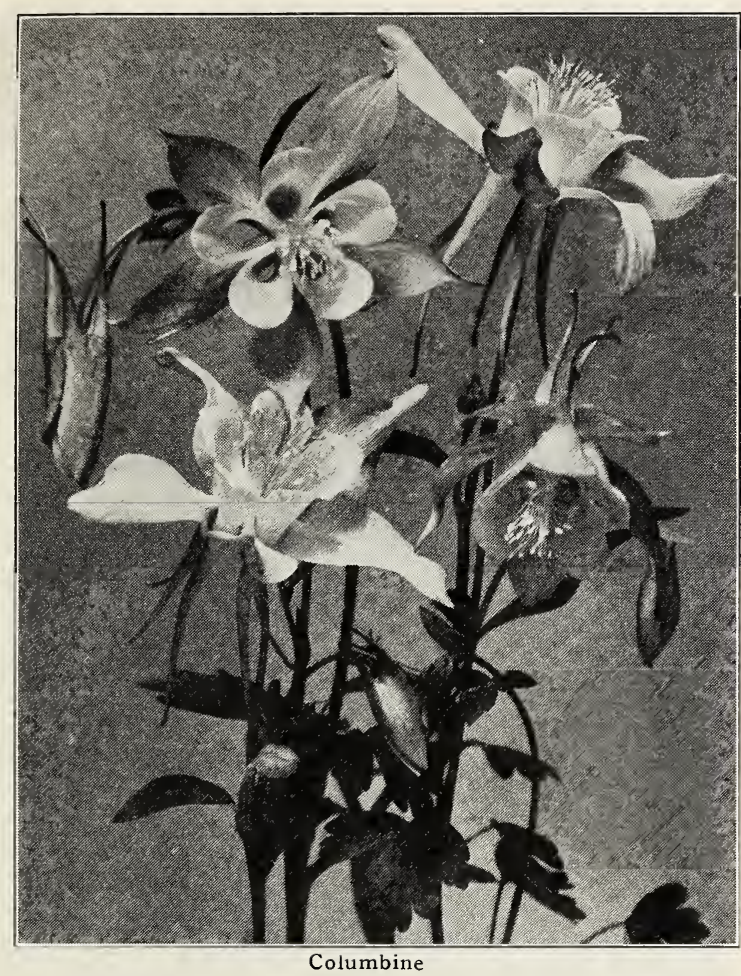

\section{Columbine (Aquilegia)}

Charming, hardy perennial plants, growing from 1 to 3 feet high, bearing in countless numbers, through May and June, their exquisite blossoms of clear blue, white, rose, yellow, purple, striped, etc. For planting in permanent borders or naturalizing along the edges of woods or shrubbery, this old-fashioned favorite is one of the best of all hardy plants. Sow the seed in boxes to transplant.

CHRYSANThA (Golden Spurred) - Golden yellow. Pkt., 10c.

COERULEA (Rocky Mountain Columbine)-Violet-blue and white; 2 feet. Pkt., 15c.

LONG SPURRED PINK HYBRIDS-A beautiful selection of pink and rose shades. Pkt., 25c.; 5 pkts., $\$ 1.00$.

MRS. SCOTT ELLIOTT'S STRAIN-This strain is allowed by the Royal Horticultural Society to be the best ever raised. The blooms are of large size and the spurs very long. The colors range through shades of lavenders, mauves, blues, purples, whites, creams, yellows, pinks, reds, etc. Pkt., 25c.; 5 pkts., $\$ 1.00$.

LONG SPURRED HYBRIDS, MIXED-A great variety of colors. Pkt., 15c.; $1 / 8$ oz., 50c.

DOUBLE_All colors mixed. Pkt., 10c.; I/4 oz., $30 \mathrm{c}$.

CONvorvurus-See Morning Glory.

\section{Cypress Vine}

\section{(Ipomoea Quamoclit)}

A beautiful annual climber, with delicate, dark-green, feathered foliage, and an abundance of bright, star-shaped blossoms. The seed will sprout more readily if allowed to soak in lukewarm water for a few hours before sowing. Sow the seed in the open in April, or when the weather becomes warm.

SCARLET, pkt., 10c.; oz., 50c. WHITE, pkt., 10c.; oz., 50c. MIXED COLORS, pkt., 10c.; oz., 50c.

QUAMOCLIT HYBRIDA (Cardinal Climber) -Beautiful fern-like foliage and brilliant cardinal flowers. Pkt., 15c.

\section{Cosmos}

The plants grow 5 to 6 feet high, and are one mass of feathery green foliage, gemmed with large single flowers of white, pink, or crimson, enlivening the garden long after more tender flowers have succumbed to early frosts. For bouquets and vases this is one of the finest flowers grown. This half hardy annual may be sown from February until June. Sow in boxes to transplant or out of doors if cold weather is over and thin to 12 inches apart.

\section{Giant Late or Lady Lenox}

The finest late flowering type, bearing giant flowers with broad and overlapping petals of splendid substance. The plants, 5 to 6 feet high, are of symmetrical pyramidal form. GIANT PINK-Bright pink. Pkt., 10c.; $1 / 4$ oz., 20c. GIANT WHITE-Pure white. Pkt., 10c.; $1 / 4$ oz., 20c. GIANT CRIMSON-Brilliant crimson. Pkt., 10c.; $1 / 4$ oz., 20c. GIANT IMIXED_Contains an even proportion of the above colors. Pkt., 10c.; oz., 50c.

\section{Mammoth Early Flowering Cosmos}

A great improvement on the ordinary early flowering type. Plants grow $3 \mathrm{I} / 2$ to 4 feet tall and produce immense flowers in 60 days from time of sowing.

MAMMOTH EARLY PIPK-Pkt., 10c.; $1 / 4$ oz., 25c. MIAMIIOTH EARIY WHITE-Pkt., 10c.; $1 / 4$ oz., 25c. MAMIMOTH EARLY CRIMSON-Pkt., 10c.; $1 / 4$ oz., 25c. MIAMMOTH EARIY IMIXED-Pkt., 10c.; $1 / 4$ oz., 20c.; oz., 60c. KLONDYKE-A dwarf late-blooming variety, with orange-yellow blossoms. Pkt., 15c.; 1/4 oz., 60c.

\section{Double Crested Cosmos}

The plants grow $3 \frac{1}{2}$ to 4 feet tall and produce a small percentage of flowers having double centers and a row of petals around the base of the flower which makes them very effective.

PINK BEAUTY_Soft pink. Pkt., 15c.; $1 / 4$ oz., 60c. WHITE QUEEN-Pure white. Pkt., 15c.; $1 / 4$ oz., 60c. CRIMSON KING-Dark crimson. Pkt., 15c.; I/4 oz., 60c. Mixture of the above colors-Plit., $15 \mathrm{c}$.; $1 / 4$ oz., $50 \mathrm{c}$.

\section{Cynoglossum Amabile (Chinese Forget-Me-Not)}

A hardy perennial recently introduced from China, of the easiest culture, forming strong plants about 18 inches high and producing through the summer months sprays of brilliant blue Forget-me-not-like flowers. Pkt., 15c; 1/4 oz., 40c.

\section{Double Daisy}

\section{(Bellis Perennis)}

A hardy perennial, blossoming freely all Spring and Summer. Plant is about 4 inches high and is valuable for borders. Is niuch sown in lawns. Sow the seed in boxes to transplant. If sown early will flower the first season.

EXTRA DOUBLE WHITE or SNOWBALL-A clear white variety. Pkt., 10c.; 1/8 oz., 50c.

IONGFELIOW-Double dark rose. Pkt., 10c.; 1/8 oz., 50c.

GIANT WHITE_Flowers are very large and the plants of vigorous growth. Pkt., 15c.

GIANT ROSE-Same as the above except in color. Pkt., 15c.

GIANT QUILIED RED-A distinct and most pleasing color. Pkt., $25 \mathrm{c}$.

GIANT MIXED_Pkt., 15c.

EXTRA DOUBLE-Mixed. Pkt., 10c.; $1 / 8$ oz., 40c

SINGIE LAWN DAISY-Pkt., 10c.; $1 / 8$ oz., $25 \mathrm{c}$.

\section{Shasta Daisy}

A fine perennial plant bearing large white single blossoms with yellow centers; an excellent cut flower and admired everywhere. Soak seed in warm water overnight before sowing. Sow in boxes and transplant when well started.

ALASKA - The best variety. Pkt., 10c.; $1 / 8$ oz., 35c.

DELPHINIUMI-See Larkspur,

DIGITALIS-See Foxglove. 


\section{Dahlia}

One of the best late Summer and Autumn flowering plants, and now enjoying a wide popularity; the double and cactus sorts will bloom the first season if the seed is sown before the beginming of April; the single sorts will bloom from seerl sown in the open ground as late as May. altlough an earlier start is better.

DOUBLE CACTUS Mixture from named sorts. Pkt., 15c.

DOUBLE MIXE-Pkt., 15c.

PAEONY FLOWERED MIXED-Pkt., 15c.

SINGIE COLOSSAI MIXED-Pkt., 10c.

\section{Dianthus Plumarius}

\section{(Clove Pinks)}

Harly pereminial. low-growing pinks, extensively used for borders and edging. Free flowering and fragrant.

CYCLOPS - Large single and semi-double fringed flowers in various rose and red shades with clove-like fragrance; produced in great abundance. Pkt., 10c.; I/8 oz., 50c.

GRASS PINK, SCOTCH or PHEASANT'S EYE PINK-A beautiful single hardy Pink, with fringed-edged white flowers with a crimson center. Pkt., 10c.; $1 / 4$ oz., 35 c.

DOUBLE CLOVE PINKS-Double and semi-double varieties in beautiful colors. Mixed. Pkt., 15c.; $1 / 4$ oz., $60 \mathrm{c}$.

DOUBLE WHITE CLOVE PINKS-Very fragrant. Pkt., 15c.

SEMPERFLORENS OF EVERBIOOMING HARDY GARDEN

PINKS-A mixture of beautiful double rose and red hybrids; very sweet scented. Pkt., 25 c.

ALIWOODI (Perpetual Flowering Hardy Pinks) -Our supply of this beautiful strain of Hardy Pinks comes to us direct from the introducer, a noted English specialist. It is expected that the seed will produce an average of 75 per cent double, deliciously clove-scented flowers in many colors. They are perfectly hardy and flower continuously from Spring until late in the Autumn. Pkt. of 25 seeds for 35c.

IATIFOLIUS ATROCOCCINEUS FL. PI. (Everblooming Hybrid Sweet William)-This is a cross between an Annual Pink and Sweet William, combining the free and continuous blooming qualities of the former with the hardiness of the latter; color is an intense velvety crimson-scarlet. Pkt., 15c.

CAESIUS (Cheddar Pink) - A splendid rock plant, forming dense tufts 3 inches high, with delicate rose colored flowers in May and June. Pkt., 15c.; $1 / 4$ oz., 50c.

\section{Dianthus, or Pinks}

Hardy anuuals, about 1 foot ligh, and bearing beautifully colorerl. single and double blossoms in profusion all Summer. Sow seel from February to May in boxes and transplant, or sow in rows where the plants are to remain, and thin.

HEDDEWIGI, FL. PI. (Japan Pink)-Large double flowers, fine color; mixed. Pkto, 10c.; $1 / 4$ oz., 30c.

CHINENSIS (Indian Pink) - Finest double mixed. Pkt., 10c.; $1 / 4$ oz., $25 \mathrm{c}$.

IACINIATUS Finest single fringed variety, in choice colors. Mixed. Pkt., 10c.; $1 / 4$ oz., $25 \mathrm{c}$.

Diadematis (Double Diadem Pink) - Fine mixed. Pkt., 10c.

ATROPURPUREUS AIBO MARGINATUS, FL. PL. (MOURning Cloak) - Double deep blackish crimson, with white edge. Pkt., $10 \mathrm{co} ; 1 / 4$ oz., $35 \mathrm{c}$.

CRIMSON BELLE_Single, brilliant crimson. Pkt., 10c.; $\mathrm{I} / 4$ oz., $35 \mathrm{c}$.

FIREBALI_Double rich scarlet; compact. Pkt., 10c.; I/4 oz., $50 \mathrm{c}$.

SNOWBALL-Double fringed white. Pkt., 10c.; $1 / 4$ oz., 50c.

SALMON KING-Double brilliant salmon-rose. Pkt., 10c.; $2 / 4$ oz., 50c.

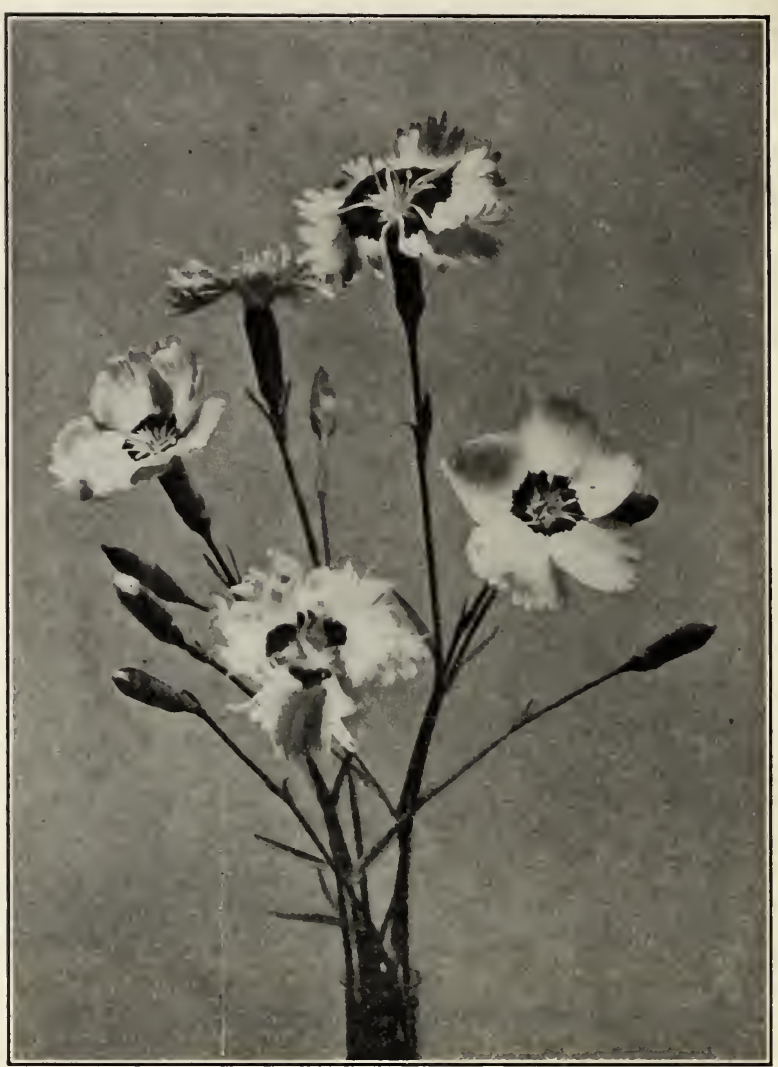

Dianthus Cyclops

\section{Diascia Barberae}

A very attractive little plant, blooming freely in Summer. The flowers lave two short spurs and are a beautiful salmon pink. It is a fine rock plant and also makes a good pot plant for indoor use; hardy perennial. Pkt., 15c.

\section{Didiscus Coerulea}

(Blue Lace Flower)

This annual should be grown extensively for cutting purposes. The plants grow 18 to 24 inches high, flowers are light blue in flat clusters 2 to 3 inches across and are borne on long stout stems. Pkt., 15c; 1/4 oz., 50c.

\section{Dimorphotheca Aurantiaca}

(The African Golden Orange Daisy)

This half liardy ammual of neat branching liabit grows 12 to 15 inches high, and is exceedingly profuse in flowering. The marguerite-like blossoms are a rich, glossy, orange-gold and measure $2 \frac{1}{2}$ inches in diameter. Sow in boxes to transplant from February to May.

AURANTIACA-Orange. Pkt., 10c.; $1 / 4$ oz., 40c.

AURANTIACA HYBRIDS - Various shades of white, yellow, orange and salmon. Pkt., 10c.; $1 / 4$ oz., $40 \mathrm{c}$.

\section{Dolichos (Hyacinth Bean)}

A rapid-growing annual climber; flowers freely in erect racemes, followed by ornamental seed pods. Sweet scented. Sow the seed in the open ground in April or May.

WHITE, PURPLE or MUXED-Pkt., 10c.; oz., $25 \mathrm{c}$. 


\section{HALLAWELL SEED CO. FLOWER SEEDS SAN FRANCISCO, CaLIF.}

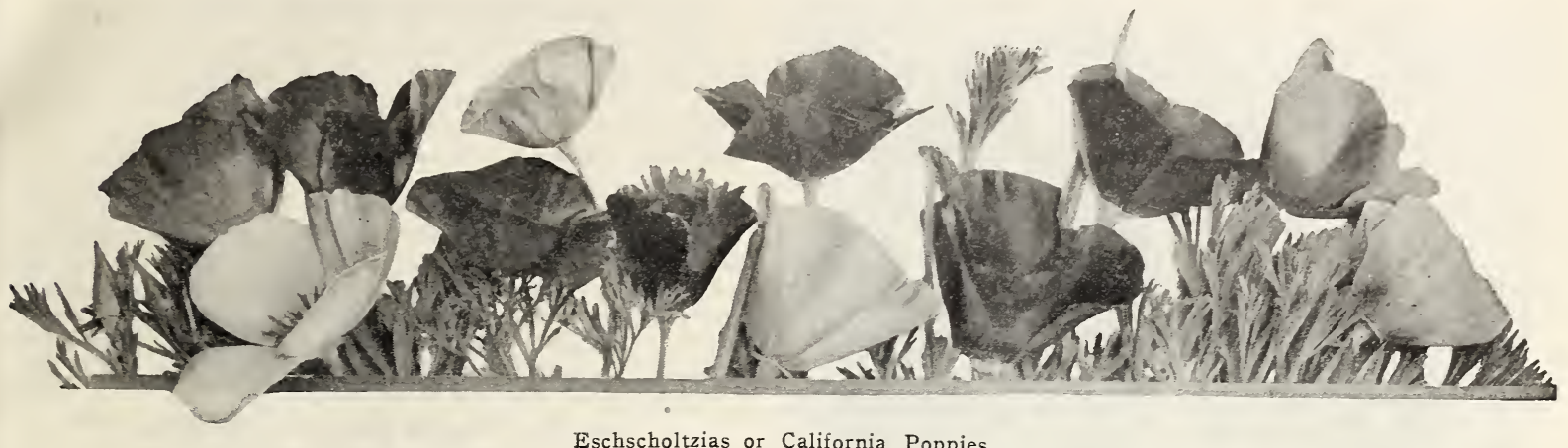

\section{Eschscholtzia}

(California Poppy)

A hardy annual. Sow seed where the plants are to remain, as they do not transplant easily. Seed can be sown in the Fall till April or May.

CAIIFORNIA "RFSRLECTED"-A selected type of the common variety, being a deep, rich orange. Pkt., 10c.; oz., 30c.; lb., $\$ 2.75$.

CRIMSON-Deep crimson. Pkt., 10c.; 1/4 oz., 25c.; oz., 75c.

CHROME QUEEN-Clear chrome yellow. Pkt., 10c.; oz., 50c.

GEISHA-Petals prettily fluted, color inside of petals brilliant golden and outside intense orange. The most beautiful of all Eschscholtzias. Pkt., 10c.; $1 / 4$ oz., 25c.

PURPLE GIOW-Bright reddish-purple; the darkest shade that has been obtained so far. Pkt., 10c.; ' $1 / 4$ oz., $40 \mathrm{c}$.

ROSY QUEEN-Rosy pink. Pkt., 10c.; oz., 50c.

SCARLET BEAUTY-Vivid scarlet, plants are bushy and of erect habit; new and very fine. Pkt., 10c.; $1 / 4$ oz., $40 \mathrm{c}$.

VESUVIUS-Rich glistening wallflower red. Pkt., 10c.; oz., 50c.

WHITE-Ivory white. Pkt., 10c.; oz.y 50c.

Collection of the above 9 sorts, $75 \mathrm{c}$.

MIXED COLORS_Pkt., 10c.; oz., 30c.; lb., \$3.00.

NEW HYBRIDS MIXED-New, large flowering, erect type, con taining a large percentage of new shades in Eschscholtzias and includes soft pink, scarlet, chrome, copper, red, claret, cream and purple. Pkt., 10c.; $1 / 4$ oz., $25 \mathrm{c}$.; oz., $75 \mathrm{c}$.

\section{Euphorbia}

Half hardy annuals suitable for beds of tall growing plants or mixed borders; the flowers are inconspicuous but the foliage is very ornamental. Sow from February to May.

HETEROPHYLLA (Annual Poinsettia, Mexican Fire Plant)The plants grow 2 to 3 feet high, of branching habit, with smooth, glossy, green leaves which become a bright scarlet in Summer. Thrives in warm localities only. Pkt., 15c.

VARIEGATA (Snow on the Mountain) - Attractive foliage veined and margined with white. Pkt., 10c.

\section{Exacum Affine}

A beautiful rich blue; sweet scented. A most elegant plant for pots. Seed sown in the greenhouse in March will make specimen plants in 5-inch pots in Summer; for larger specimens, sow seed in August for next summer's blooming. Pkt., 35c.

\section{Four O'Clock or Marvel of Peru}

A hardr annual, about 2 feet high. Of the easiest culture. Seed should be sown from February to May in the open and thinned to 1 foot. Is free-flowering. the blossoms come in great variety of colors and stripes. Mixture of all colorsPkt., 10c; oz., 25c.

\section{Freesia Hybrida Ragionieri}

The flowers come in great variety of new colors. They will bloom next Spring if the seed is sown before the first of Mar. Pkt., 15c.

\section{Forget-Me-Not (Myosotis)}

A hardy perennial, growing 6 to 12 inches high. Small star-like flowers are borne in clusters on long stems. The plant is of easy culture and blooms the first year if seed is sown early. Thrives best in a cool, moist location.

ALPESTRIS-Blue. Pkt., 10c.; I//4 oz., 35c.; oz., $\$ 1.00$.

INDIGO or ROYAI BLUE-A rich dark indigo blue color. Pkt., $10 \mathrm{c}$; $1 / 4$ oz., $40 \mathrm{c}$.

WHIrs-Pkt., 10c.; I/4 oz., 35c.

PINK-Pkt., 10c.; $1 / 4$ oz., 35c.

BLUE PERFECTION-Beautiful dwarf indigo-blue, very compact. Pkt., 15c.; $1 / 4$ oz., $75 \mathrm{c}$.

VICTORIA-Large sky-blue flowers, dwarf habit. Pkt., 10c.; $\mathrm{T} / 4$ OZ., 50c.

ROBUSTA GRANDIFLORA-Strong grower, with clear blue flowers, 10 inches tall. Pkt., 10c.; I/4 oz., 40c.

PALUSTRIS SEMPERFLORENS-Dwarf blue variety, ontinuing in bloom from early Spring until Autumn. Pkt., 15c.;
$1 / 4$ oz., 85 c.

\section{Foxglove (Digitalis)}

Handsome hardy peremnial plant of stately growth and long spikes of finely colored flowers; fine for shrubberies and half shadr places; brilliant colors. Sow the seed in boxes to transplant or in the open in a cool place.

GLOXINIAEFLORA-Improved Strain of the ordinary variety : ROSE-Pkt., 10c. PURPLE-Pkt., 10c. WHITE-Pkt., 10c. YELLOW-Yellow changing to primrose. Pkt., 25c. MIXED, ALL COLORS-Pkt., 10c.; $1 / 4$ oz., 30c. GIANT SHIRLEY_See specialty page 28 .

\section{Gaillardia}

A very showy garden plant, with brilliant flowers in scarlet and yellow, blended and shaded. Blooms freel $y$ from early Summer till Autumn. Grows 11/2 to 2 feet high, and the blossoms are borne on long, slender stems. Both single and double varieties are hardy. Sow seed in boxes to transplant.

FINE SINGLE MIXED, ANNUAL-Pkt., 10c.; $1 / 4$ oz., 25c. DOUBLE MIIXED, ANNUAL (Picta Lorenziana)-Pkt., 10c. $I / 4$ oz., $25 c$.

GRANDIFIORA-PORTOLA HYBRIDS-Shades of bronzy red, golden tipped, very robust. A new variety. Pkt., 25c.

GRANDIFIORA-Single perennial variety of varying shades of reddish brown and yellow. Pkt., 10c.; I/4 oz., 30c.

GIANT HYBRIDS-A very choice strain; flowers of very large size in various colors; perennial. Pkt., 15c.; I/4 oz., $50 \mathrm{c}$.

\section{Gaura Lindheimeri}

A half hardy perennial bearing ross-white flowers on slender spikes 3 to 4 feet tall. Will bloom first year if started indoors in January and February. Pkt., 15c.

\section{Geranium}

A half hardy perennial, flowering the first year from seed sown early.

FANCY SHOW PELARGONIUM, OI LADY WASGINGTONOne of the most beautiful flowers we have: in rich, soft colors with beautiful markings. Fancy mixed. Pkt., 25c. ZONALE-Choice varieties mixed. Pkt., $15 \mathrm{c}$. 


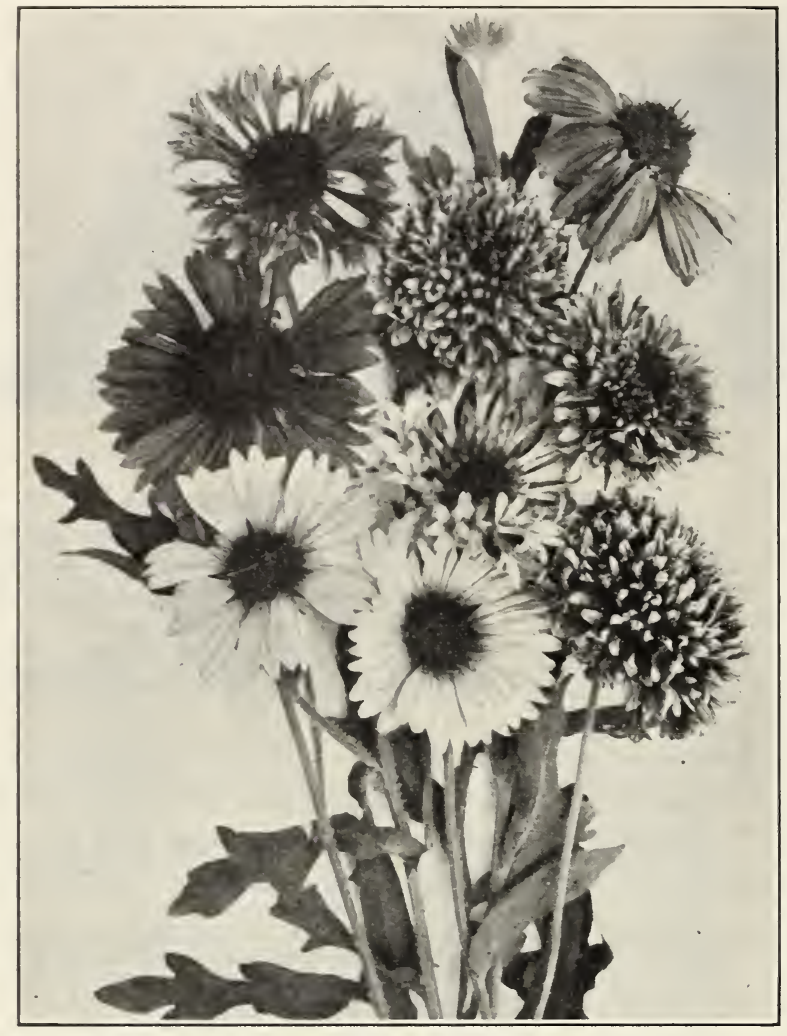

Single and Double Annual Gaillardias

For varietics, see preceling page.

\section{Gesnera (Naegelia)}

Profuse bloming greenhouse plants. The flowering spikes ars thrown np in great abmonce and carry numerous bright, pendulous flowers, including pure white, yellow, salmon fink, orange, rose, (amine and rich crimison. Finest lıybrids. Pkt., 50c.

\section{Geum}

MRS. BRADSHAW-A showy hardy perennial with large double brilliant scarlet flowers borne on long stems. Useful for cutLADY STRATHEDEN-A grand novelty. Fine rich golden-yellow flowers which match in other respect: the popular scarlet

\section{Gilia}

Hardy annul California wild flower. Sow the sced in the open wither in the Fall or Spring.

CAPITATA, "BLUE GIIIA"-A slender branching plant $1 \frac{1}{2}$ to $21 / 2$ feet high: flowers likht blue in dense globular heads. Pkt.,
$10 \mathrm{c}$; $0 z ., 40 \mathrm{c}$. TRICOLOR, "BIRDS EYES"-Flowers pale lilac, yellow toward the center with five purple spots; 9 to 12 inches high. Pkt.,
$10 \mathrm{c}$; 0z., $40 \mathrm{c}$.

\section{Gloxinia}

Beautiful hothouse plants, with large, bell-shaped blossoms, which come in rich, velvety deep and briglit colors. some of which are beautifully markerl. Sow in Fall or early Sipring

\section{Gomphrena, or Globe Amaranth}

A half hardy amual everlasting or straw flower, growing about $S$ inches high with flowers which resemble large clover heads and can be dried and used in Winter bouquets. Mixed colors. Pkt., 10c; $1 / 4$ oz., 25 c. ORANGE-Known as "Strawberry Flower." Pkt., 10c.; $1 / 4$ oz.,
30c.

\section{Godetia}

() all hardy garlen ammals few are more beautiful than the Godetia, boing exceedingly showy when grown in beds and masses; bears freely, flowers of fine size. of exquisite rolors and shates, and glistening in the sumlight like satin; comparet and busly in growth. Height 1 to 2 feet. Sow seed in the open ground in the Fall for early bloom or any time in Spring until May for later flowering.

\section{DOUBLE FLOWERED VARIETIES}

Of distinct and graceful habit, producing long sprays of beautiful, large, double flowers, which are fine for cutting and excellent for the border. Height 2 feet.

DOUBLE CARMINE-Bright carmine flowers, edged more or less with white. Pkt., 10c.; $1 / 4$ oz., 30c.

DOUBLE CRIMSON-An intense crimson shade. Pkt., 10c.; I/4 oz., $30 \mathrm{c}$.

DOUBLE MAUVE-An attractive shade of clear pinkish mauve. Pkt., 10c.; 1/4 Oz., 30c.

DOUBLE ROSE-A soft pink color with bright carmine center.

Pkt., 10c.; $1 / 4$ oz., 30c.

DOUBLE ROSX MORN-A beautiful bright pink color. Pkt.,

$10 \mathrm{c}, \mathrm{i}_{1 / 4}$ oz., $30 \mathrm{c}$.

Collection of one packet each of the above 5 sorts, $45 \mathrm{c}$. DOUBLE MIXED-All colors. Pkt., 10c.; 1/4 oz., 25c.; oz., 75c. SINGLE FLOWERED VARIETIES

DUCHESS OF AIBANY-Large, glossy, satiny white flowers, Two feet. Pkt., 10c.; $1 / 4$ oz., $30 \mathrm{c}$.

LADY ALBEMARLE-Large, brilliant crimson. One foot. Pkt., 10c.; $1 / 4$ oz., $30 \mathrm{c}$.

LORD ROBERTS-Darkest glowing red with white base; very fine; of compact habit. Pkt., 10c.; $1 / 4$ oz., $30 \mathrm{c}$.

ROSAMOND_Large glossy pink; compact. Pkt., 10c.; $1 / 4$ oz., 30c. SEMI-DWARF VARIETIES-Splendid mixture of brilliant colors. Pkt., 10c.; 1/4 oz., 25c.; oz., 75c.

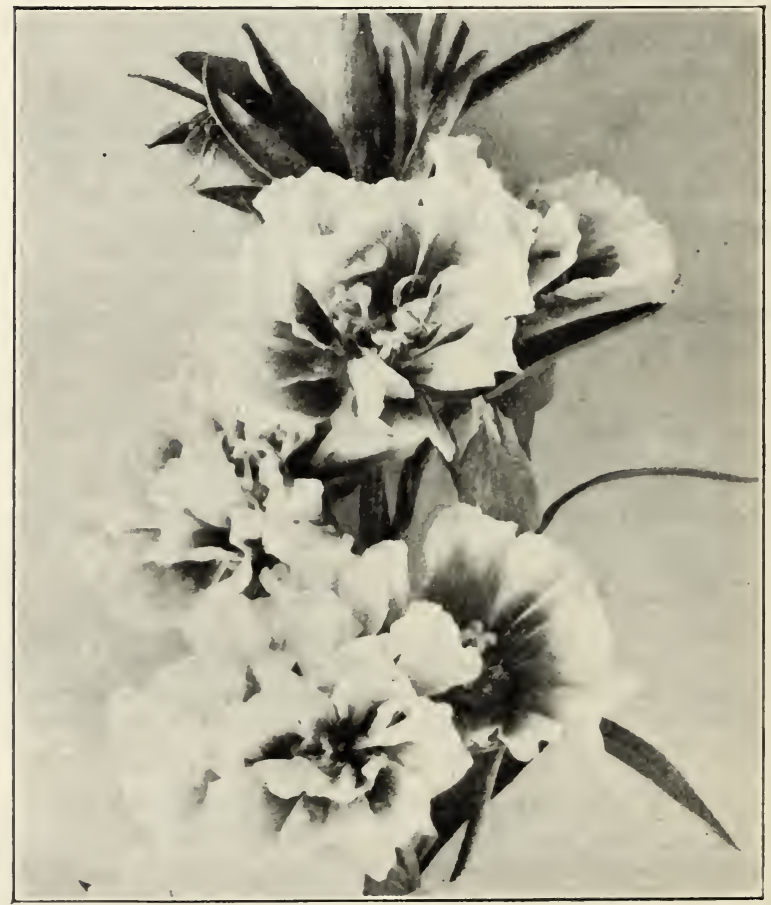

Double Godetia 


\section{Gourds, Ornamental}

Excellent for covering verandas or trellis work and for training over arbors, fences, etc. Sow outside where they are to remain when the ground becomes warm.

AFRICAN PIPE-The stem end of the fruits is used in making

Calabash pipes. Pkt., 10c.

CHINESE BOTTIE-Pkt., 10c.

CHINESE IOOFA (Sponge or Dish-Rag)-Pkt., 10c.

DIPPER or SIPHON-Makes a convenient dipper. Pkt., 10c.

HFRCULES CLUB-Club-shaped fruits, 4 feet long. Pkt., 10c.

NFST-FGG-White like an egg. Pkt., 10c.

ORANGE-SHAPED (Mock Orange)-Small. Pkt., 10c.

PEAR-SHAPED-Striped yellow and green. Pkt., 10c.

TURBAN-Red striped, small. Pkt., 10c.

Collection of the above 9 sorts, 75c.
MIXED ORNAMIFNTAI VARIETIES-Pkt., 10c.; oz., 25 c.

GRASSES, ORNAMENTAI (See page 54)

\section{Gypsophila}

(Baby's Breath)

A hardy annual of easy culture. Grows 2 to 3 feet high, and bears a profusion of small star-shaped white flowers. Sow the seed outside in the Fall or in Spring.

PANICUIATA-Fine for bouquets; white flowers; perennial. Pkt., 10c.; $1 / 4$ oz., 25c.

PANICULATA, FI. PI.-A new double white flowering perennial sort. Pkt., 25 c.; $1 / 8$ oz., $\$ 1.00$.

ELEGANS GRANDIFIORA-Improved annual white sort. Very largely grown by florists for use in bouquets. Pkt., 10c.; oz.,

FIFGANS CARMINEA-A new free-flowering variety with carmine rose blossoms; 2 to 3 feet tall. Pkt., 10c.; oz., 35c.

HEIIANTHUS (See Sunflower)

\section{Helichrysum}

(Everlasting Flower)

A free-flowering, hardy annual, growing 2 to 3 feet high and bearing beautiful straw-like flowers in a great variety of shades and colors. The stems are long and the blossoms large. It is the best and most satisfactory of the everlasting flowers and makes a very handsome dried bouquet. Sow the seed in Spring in the open and thin out to at least 1 foot apart.

CANARY YFLLOW-Pkt., 10c.; $1 / 4$ oz., $30 \mathrm{c}$.

FIREBAII_-Bright red. Pkt., 10c.; $1 / 4$ oz., $30 \mathrm{c}$.

GOIDEN BALI-Golden yellow. Pkt., 10c.; $1 / 4$ oz., $30 \mathrm{c}$.

SAIMON-Pkt., 10c.; $1 / 4$ oz., 30c.

SIIVER BAII_Pure white. Pkt., 10c.; I/4 oz., 30c.

ROSE CARMINE-Rich and glossy. Pkt., 10c.; 1/4 oz., 30c.

Collection of the above 6 sorts, 50c.

MONSTROSUM-Mixed. Pkt., 10c.; I/4 oz., 25c.; oz., 75c.

HESPERIS-See Sweet Rocket.

\section{Heliopsis Pitcheriana}

(Orange Sunflower)

A hardy perennial growing 3 to 4 feet high, beginning to flower early in the season and continuing the entire season. The flowers are deep golden-yellow about 2 inches in diameter; of thick texture and very graceful for cutting. Pkt., $10 \mathrm{c}$.

\section{Heliotrope}

A half hardy perennial, growing 4 to 8 feet high. Small flowers, borne in graceful clusters and very fragrant. Blooms the first season from seed if sown early. Forms a large plant and requires a roomy situation. Can also be grown against a wall and made to assume the character of a climber. Sow the seeds from February to May in a box and transplant.

REGAI (Dwarf Giant Flowered Heliotrope)-A very fine improved variety of dwarf habit with immense heads of flowers in various shades of blue. Pkt., 25c.

FINEST MIXED-A mixture of the ordinary true type. Pkt., 10c.; $1 / 8$ oz., $30 \mathrm{c}$.

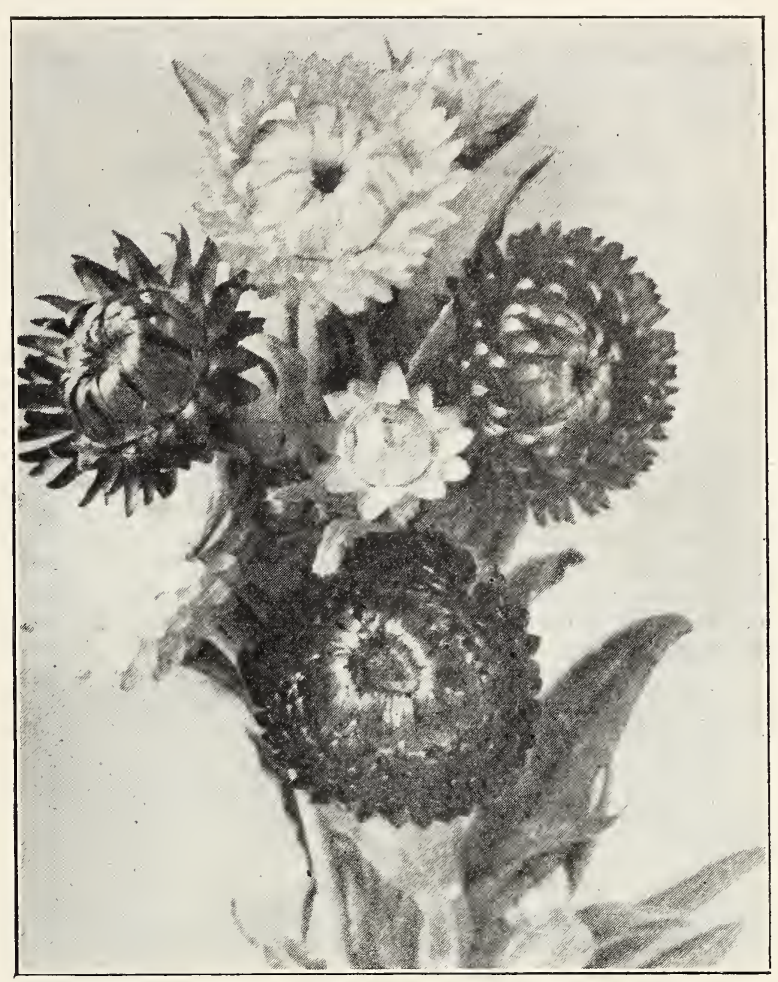

Helichrysum

\section{Heuchera Sanguinea}

(Coral Bells)

A low growing plant with heart-shaped leaves, which form a low clump 6 to 8 inches high and bearing during the Summer, loose graceful sprays of coral-red flowers in great profusion; suitable for the border or rockery. Pkt., 25c.

\section{Hibiscus}

CRIMSON EYE-Immense flowers of pure white with crimson eye. Plants grow about 4 feet high and are covered with blossoms. Perennial; will bloom first season if sown early. Pkt., 10c.

GOIDEN BOWI-Deep cream with velvety maroon center. Pkt. 10c.

\section{Hollyhock}

A hardy perennial of upright, stately growth, 5 to 8 feet high. The very double varieties are the most desirable, but the newer, semi-double fringed types are also very popular. Hollyhocks make a fine row in a garden, or a fine background next to a building or high wall or fence. They flower in Summer and Fall. The seed we offer has been saved from Chater's unrivaled collection of choice improved double varieties.

DOUBIE BRIGHT RED; DOUBLE CANARY YELIOW; DOUBLE ROSE PINK; DOUBLE MLROON; DOUBLE NEWPORT PINK (Pure Pink); DOUBLE WHITE.

Any of the above, per pkt., 10c.; $1 / 4$ oz., 50c.

Collection of the above 6 sorts, $50 \mathrm{c}$.

DOUBIE, AII COIORS MIXED-Pkt., 10c.; 1/4 oz., 40c.

AIIEGHENY FRINGED-The large flowers are single and beautifully fringed. All colors mixed. Pkt., 10c.; $1 / 4$ oz., $35 \mathrm{c}$.

SINGIE, AII COIORS MIXED-Pkt., 10c.; $1 / 4$ oz., $35 \mathrm{c}$. 


\section{Honesty}

SATIN FLOWER (Moon Plant) - The flat silvery seed pods are used for Winter decoration. Free-flowering, hardy bienniai. Two feet. Pkt., 10c.; I/s oz., 30c.

IBERIS - See Candytuft.

\section{Humulus, or Japanese Hop}

A rapid-growing, half hards climbing anmual with dense. leaves. Will grow 20 to 30 feet in a season. Sow in the open from February to Mas.

JAPONICUS-Bright green foliage. Pkt., 10c.; 1/4 oz., 25c.

JAPONICUS VARIEGATUS-Bright, variegated yellow, white and green leaves. Pkt., 10c.; $1 / 4$ oz., 25c.

\section{Hunnemannia}

(Bush Eschscholtzia)

Known also as the Santa Barbara Poppr. Seed sown in April or early in May will, by the middle of July, produce plants covered with their large buttercup-yellow, poppylike blossoms, and never out of flower until hard frost. The plants grow about 2 feet high, are quite bushy, with beautiful feathery glaucous foliage, and fine for cutting, remaining in good condition for several days.

FUMARIAFOLIA-Pkt., 10c.; $1 / 4$ oz., $25 \mathrm{c}$.

\section{Impatiens (Zanzibar Balsam)}

HOLSTII HYBRIDS-A very attractive plant for pot culture. The

branches are semi-transparent and the foliage is waxy green.

A very free and continuous bloomer. Flowers come in different

shades of pink, red and purplish violet. Sow in pots in a tem-

perature of 60 degrees. Pkt., 15c.

SULTANI-Brilliant rosy scarlet. Pkt., 15c.

\section{Ipomoea}

Climbers of rapid growth, with beautiful and varied flowers; for covering walls, trellises. arbors or stumps of trees they are invaluable; it is well to soak the seed in warm water overnight to assist in rapid germination.

GRANDIFLORA (Moonflower) - At night and during dull days

the plants are covered with an abundance of large, pure white

rapidly and will cover a large surface. Pkt., 10c.; $1 / 2$ oz., 30 c.; oz., $50 \mathrm{c}$.

RUBRO COERULEA (Heavenly Blue)-Large sky-blue flowers, free bloomer. Pkt., 10c.; $1 / 4$ oz., 30c.

BONA NOX (Evening Glory) - Large fragrant violet flowers, opening in the evening. Pkt., 10c.; oz., 50c.

SETOSA (Brazilian Morning Glory)-Rose-colored flowers, borne very freely in large clusters. Pkt., 10c.; oz., 40c.

\section{Jacobea}

Fres flowering annuals producing fine heads of double flowers: $1 \mathrm{r} / 2$ feet tall. Double mixed. Pkt., $10 \mathrm{c}$.

\section{Kenilworth Ivy}

A hardy peremial trailing plant, with small lavender or purple flowers, especially adapted for lunging baskets or for trailing over walls. Pkt., $15 \mathrm{c}$.

\section{Kochia Childsi}

\section{(Summer Cypress)}

A pretty half harcly anmual, forming rompart bushes about $21 / 2$ feet in height. with small frathery light green rlooping foliage, which changes, as the simmmer advances, to a deep sreen, and to a rrimson hue in september. Sow the seed in the Spring and transplant to 3 fret ajart when wr.ll started. Pkt., 10c; $1 / 2$ 0z., 30c; 0z., 50c.

\section{Kudzu Vine}

(Pueraria Thunbergiana)

A new climber of great merit. This vine will grow 8 to 10 feet the first year from seed and after it is well established will often make a growth of 50 feet in a season. Its foliage is large and it brars small racences of rosy purple pea-shaped blossoms in August. Pkt., 10c.

\section{Larkspur or Delphinium}

Taller than the anmual sorts with large flower-spikes. Indispensable for permanent beds and borders. Sow the seed in boxes or in a hotbed in the Fall or early Spring. They will rommence blossoning in July and August.

IIGHT BLUE SHADES-Pkt., 20c. PASTEL SHADES-Pkt., 20c. DEEP BLUE SHADES-Pkt., 20c.

Collection of one packet each of the above for 50c.

AZURE FAIRY-An annual variety with large azure-blue blossoms. Forms a compact free flowering bush about 1 foot high. Pkt., 15c.

BLUE BUTTERTLY-Intense deep blue, same habit of growth as Azure Fairy. Pkt., 15c.

BELLADONNA-New, beautiful turquoise blue and continuous bloomer; spikes of good size. Pkt., 20c.; $1 / 8$ oz., 60c.

CARDINALE-This is the Southern Scarlet Larkspur, growing 3 to 5 feet high and blooming in June and July. Pkt., 20c.; $1 / 8$ oz., $75 \mathrm{c}$.

HOLLYHOCK or WREXHAM STRAIN-A magnificent new race of Perennial Larkspurs, producing spire-like spikes of bloom with many new and beautiful shades, ranging from pale blue to deep indigo-blue and royal purple, with many intermediate pastel tones of mauve, pink and lavender shadings. The flowers are very large and come in both single and double forms. Pkt., 50c.

HALLAWELL'S IMPROVED HYBRIDS-A specially selected strain with large handsome flower spikes; contains a perfect blend of all the most beautiful shades of color obtainable. Pkt., $15 \mathrm{c}$; $1 / 4$ oz., $\$ 1.00$.

GOLD MEDAL HYBRIDS-Rich blue of various shades with black centers, grows 3 to 5 feet high. Pkt., 10c.; 1/4 oz., 60c.

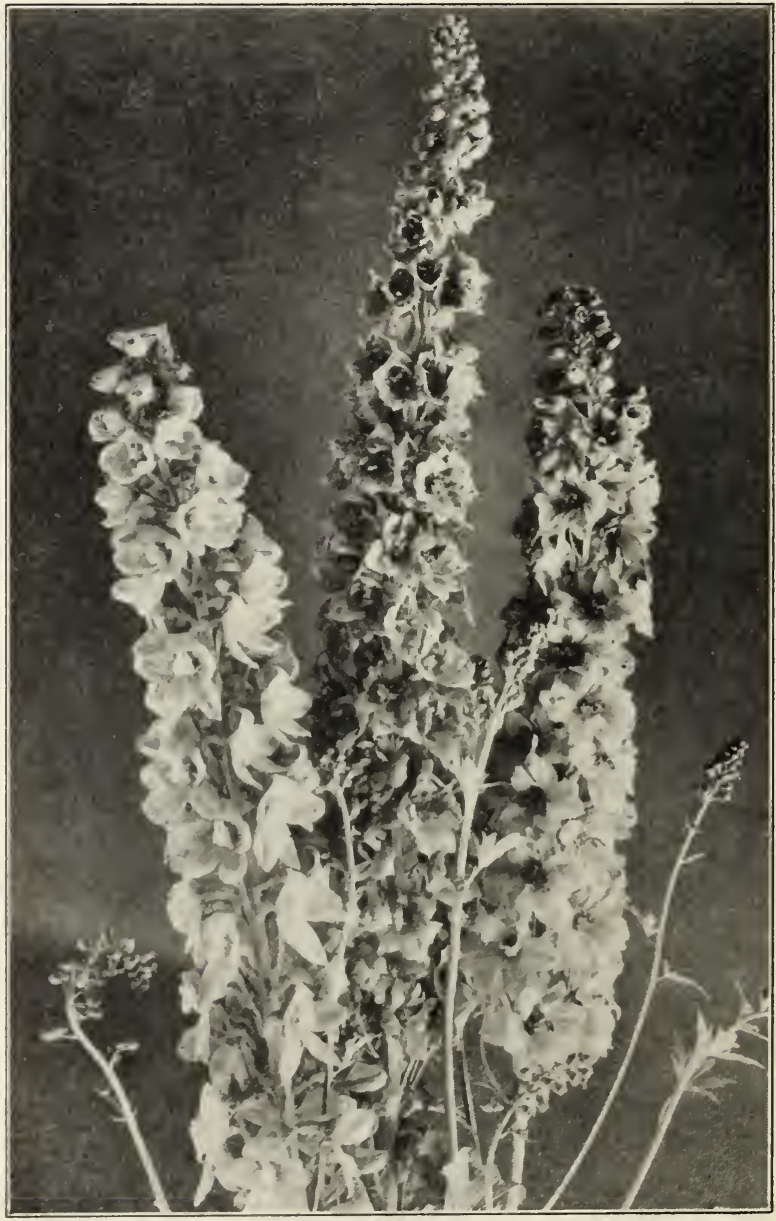

Perennial Larkspur 


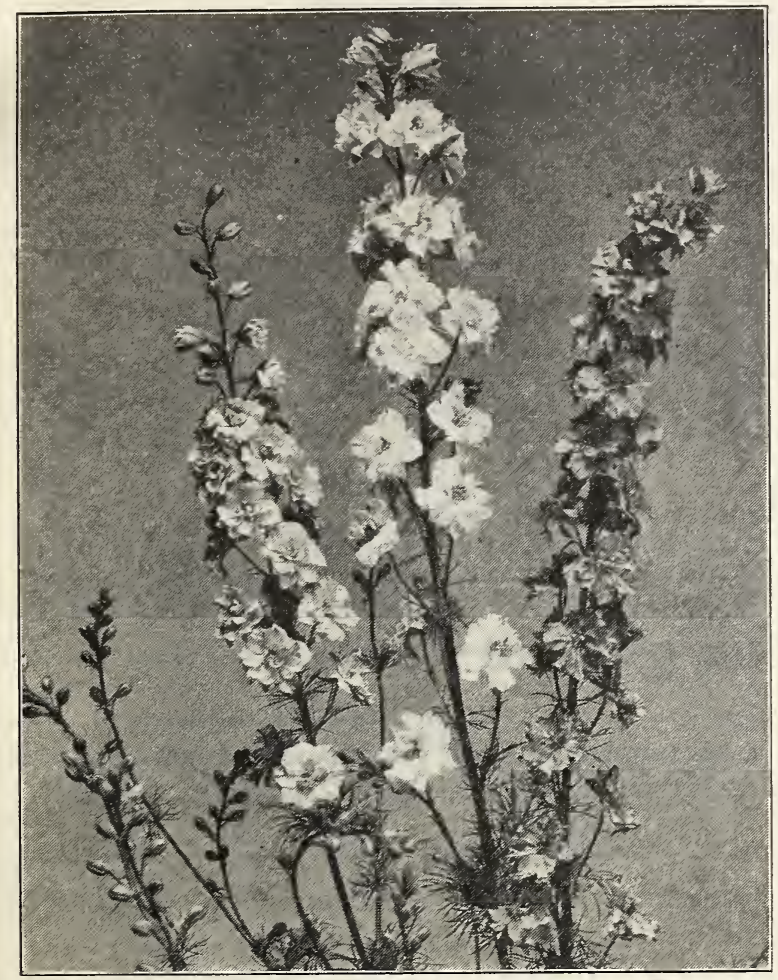

Larkspur, Double Stock Flowered

\section{Larkspur}

\section{HARDY ANNUAL VARIETIES}

Exceedingly popular and free flowering hardy annuals, growing $11 / 2$ to 3 feet high, their long spikes of flowers on long stems rendering them of exceptional value for cutting purposes. They are of long continued bloom and very bright and showy. Sow in the Fall or Spring.

DOUBLE STOCK FLOWERED-A very striking tall variety

with splendid spikes of beautiful double flowers, height, 3 feet. BRIGHT ROSE-Mauve-rose. Pkt., 10c.; $1 / 4$ oz., 30c.

DARK BIUE-Pkt., 10c.; $1 / 4$ oz., $30 \mathrm{c}$.

EXQUISITE-Beautiful soft pink. Pkt., 15c.; $1 / 4$ oz., $50 \mathrm{c}$

PURE WHITE-Pkt., 10c.; $1 / 4$ oz., $30 \mathrm{c}$.

LUSTROUS CARMINE or NEWPORT PINK-Pkt., 10c.; $1 / 4$ oz., $30 \mathrm{c}$.

AZURE BIUE-Pkt., 10c.; $1 / 4$ oz., 30c.

Collection of one each of the above sorts, $50 \mathrm{c}$.

IA FRANCE and EXQUISITE IMPROVED-See page 28

MIXTURE OF AII COIORS-Pkt., 10c.; $1 / 4$ oz., $25 \mathrm{c}$.; oz., $75 \mathrm{c}$.

\section{Lathyrus Latifolius}

(Perennial or Everlasting Pea)

A hardy perennial climber. Leaves and stem smooth. -Flowers resemble sweet peas, but are borne on strong stems, with 8 to 10 blossoms to the stem. Is not fragrant, but is hardy and showy, and thrives in any good soil.

MIXED, pkt., 10c.; WHITE PEARI, pkt., 15c.; CRIMSON or PURPIE, pkt., 10c.; PINT BEAUTY, pkt., 10c.

\section{Lavatera (Mallow)}

ASSURGENTIFIORA (Tree Mallow)-A hardy perennial growing about 10 feet high with rosy-crimson flowers. Much used for hedges or windbreaks about San Francisco. Sow in May in the open ground and thin young plants to 12 inches apart. Pkt., 10c.; oz., 35c.

SPLENDENS SUNSET-A showy and free flowering hardy annua 3 to 4 feet tall. Brilliant rosy carmine flowers. Splendid for large beds where they bloom all Summer; fine for cutting. Sow in April or May where they are to bloom and thin out to 12 inches apart. Pkt., 10c.

\section{Lavender (Lavandula Vera)}

Chiefly cultivated for the delicious and lasting fragrance of its flower; succeeds in any common garden soil. Perennial. Pkt., 10c; $1 / 4$ oz., 25c.

\section{Leptosyne Maritima}

(Sea Dahlia)

Rich golden yellow flowers resembling Marguerites, borne on long stems and good for cutting; 2 feet tall. Blooms in about six weeks from seed. Pkt., 10c; $1 / 4$ oz., 40 c.

LILIUM REGALE-See Specialty page 28.

\section{Linaria Maroccana}

Showy hardy annuals with small snapdragon shaped flowers. Grows 9 inches tall; desirable for edgings and rockeries. Sow from February to May in boxes to transplant or in the open. Finest Hybrids Mixed, pkt., 10c.

\section{Linum or Flax}

A hardy annual, about $11 / 2$ feet high. Of slender and graceful appearance, with smooth stems and bright red flowers, which are borne in great profusion. Sow from February to June out of doors.

RUBRUM_Scarlet_Pkt., 10c.; oz., 30c.

PERENNE-Bright blue, 18 inches tall; perennial. Pkt., 10c.;

$1 / 4$ oz., 25 c.

\section{Lobelia}

A half hardy annual, growing 4 to 6 inches high; is of compact growth, and literally covered with small bright flowers. By cutting back the plants during the Summer and giving plenty of water, they may be kept in flower for a long season. Used for ribbon work and borders or hanging baskets. Sow the seed in boxes in Spring and transplant when well started.

CELESTIAL BLUE-Large deep blue flowers, dwarf compact variety, very free flowering. Pkt., 15c.; $1 / 8$ oz., 60c.

CRYSTAL PAIACE COMPACTA-The variety most used for borders; deep blue flowers and dark foliage; 6 inches; a constant bloomer, Pkt., 10c.; $1 / 8$ oz., 50c.

BLUE EMPEROR-Sky blue; compact. Pkt., 10c.; $1 / 8$ oz., 40c.

GRACILIS-Light blue; trailing, light-green foliage. Pkt., 10c.

KERMESINA COMPACTA-A pretty crimson color with large white eye, very compact. Pkt., 15c.; $1 / 8$ oz., 75c.

SAPPHIRE-A superb variety of pendulous habit; large deep blue flowers with conspicuous white eye; suitable for window boxes and hanging baskets. Pkt., 15c.

SPECIOSA-Deep blue flowers and dark foliage; trailing. Pkt., 10c.

TENUIOR-A charming species with flowers which are large for the genus, being one inch in diameter. The plant is of graceful habit, reaching a height of about one foot. Useful for pots. Pkt., $15 \mathrm{c}$.

WHITE GEM (Compacta) - Snow-white flowers. Pkt., 10c.

CARDINAIIS (Queen Victoria) - -A perennial sort growing 3 feet tall with spikes of deep crimson flowers; foliage, dark red. Succeeds best in moist ground. Pkt, $25 \mathrm{c}$.

\section{Lupinus or Lupins}

Hardy annuals and perennials in great variety, growing from 1 to 3 feet high, and bearing spikes of pea-shaped flowers. Sow in the open ground and thin to 6 inches apart.

\section{ANNUAL SORTS-Two Feet}

WHITE-Pkt., 10c.; oz., 40c. DARK BIUE-Pkt., 10c.; oz., 40c. SKY BIUE-Pkt., 10c.; oz., $40 \mathrm{c}$. ROSE-Pkt., 10c.; oz., $40 \mathrm{c}$. ANNUAI SORTS-Mixed. Pkt., 10c.; oz., 25c.; 1/4 1b., 75c.

NANUS-A showy California wild flower, 10 to 15 inches high; flowers rich blue with white markings. Pkt., 10c.; oz., 35c.; $1 / 4$ lb., \$1.00; lb., \$3.25.

PERENNIAL SORTS-Four Feet

POIYPHYLIUS WHITE-Pkt., 10c.; $1 / 4$ oz., 25c. POIYPHYLLUS BIUE-Pkt., 10c.; $1 / 4$ oz., $25 \mathrm{c}$.

POIYPHYILUS MOORFEIMI-Pink and white. Pkt., 10c.; $1 / 4$ oz., 35c.

POIYPRYLIUS MIXED-Tall, perennial variety in various colors. Pkt., 10c.; 0z., 50c. 


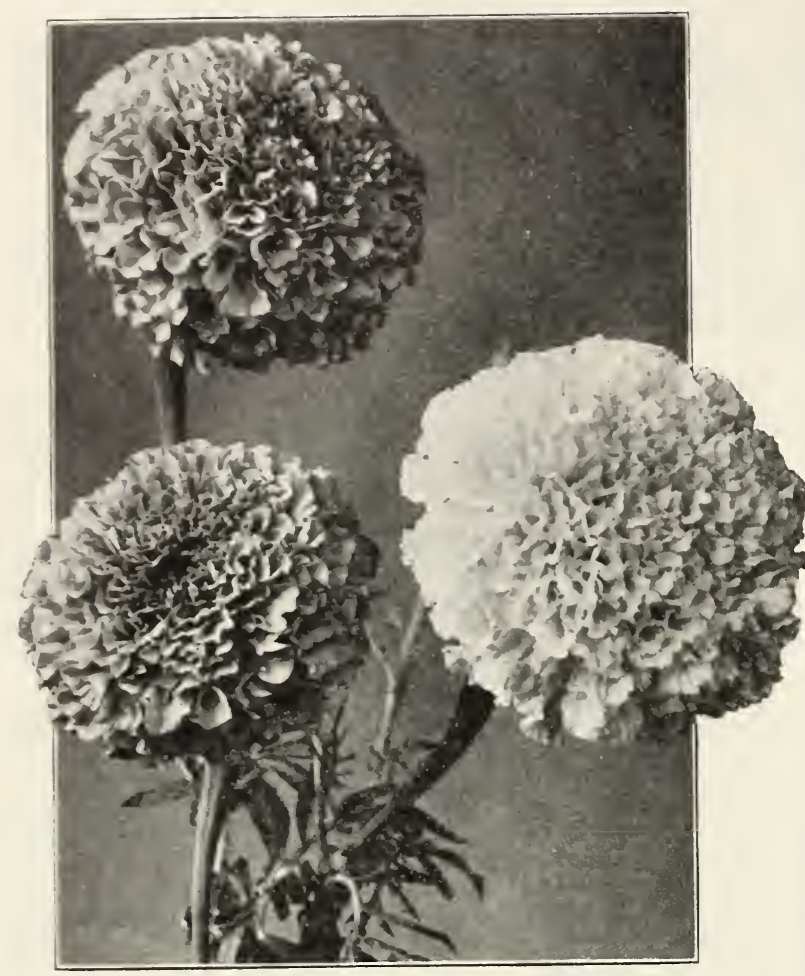

Marigold African

\section{Lychnis}

Harly perennial growing about 3 feet high and bearing bright-colored flowers in clusters. Of easy culture. Fine for permanent beds and borders. Sow the seed in boxes or in a hotberl to transplant.

ARKWRIGHTII-This new hybrid attains a height of 30 inches and produces an abundance of large flowers of brilliant color CHALCEDONICA_Scarlet flowers. Pkt., 10c.; 1/4 oz., 30c. HAAGEANA-Hybrids. Mixed colors. Pkt., 15c.; 1/8 oz., 50c.

\section{Lythrum Roseum Superbum}

Inmense spikes of bright rose-colored flowers, thriving well in moist places. Bloons very freely. Hardy perennial 4 feet tall. Pkt., 10c.

\section{Matthiola}

BICORNIS (Evening-Scented Stock) - This hardy annual has pur plish lilac flowers on long spikes, but is grown only for its iragrance, which it emits

\section{Matricaria (Feverfew)}

Free-flowering liarly plants with small double buttonlike flowers. Well arlajted for bedding or rutting. Sow seerl in boxes to trarsplant from February to May

DOUBLE WHITE-18 inches. Pkt., 10c.

GOLDEN BAIL Compact habit; suitable for edging; with double yellow flowers. Pkt., 15c.

\section{Mina Lobata}

A beautiful free-blooming half hardy annual climber with scarlet and yellow flowers. Pkt., 10c; 1/4 0z., 75c.

\section{Marigold}

A lardy annual shrubbery plant, in dwarf and tall varieties, growing from 6 inches to 3 feet high. Foliage bright green, deeply cut and graceful. The flowers are various sliades of yellow and brown. The tall varieties are very valuable for large bedding or background work and dwarf varieties for borders. Sow in boxes to transplant from Februiry to May.

\section{DWARF FRENCH VARIETIES}

LEGION OF HONOR-Single golden-yellow flowers with velvety red centers; very dwarf. Pkt., 10c.; $1 / 4$ oz., $25 \mathrm{c}$.

DWARF DOUBLE MIXED-Pkt., 10c.; $1 / 4$ oz., 25c.; oz., 75c. DWARF DOUBLE GOLD STRIPED-Pkt., 10c.; $1 / 4$ oz., $30 \mathrm{c}$. DWARF BROWN-Pkt., 10c.; $1 / 4$ oz., 30c.

DWARF GOLDEN BALL-Pkt., 10c.; $1 / 4 \mathrm{oz} ., 30 \mathrm{c}$.

\section{TALL FRENCH VARIETIES}

TALI DOUBLE BROWN-Pkt., 10c.; $1 / 4$ oz., 30c.

TAIL DOUBLE IEMON-Pkt., 10c.; $1 / 4$ oz., 30c.

TALL DOUBLE ORANGE-Pkt., 10c.; $1 / 4$ oz., 30c.

TALI DOUBLE FRENCH MIXED-Pkt., 10c.; 1/4 oz., 25c.; oz., $75 \mathrm{c}$.

TALL SINGLE BROWN-An excellent cut flower. Pkt., 10c.; $1 / 4$ oz., $30 \mathrm{c}$.

\section{AFRICAN VARIETIES}

TALI DOUBLE ORANGE PRINCE "EXTRA SELECT"-Pkt., 15c.; $1 / 4$ Oz., $50 \mathrm{c}$.

TALI DOUBLE LEMON QUEEN "EXTRA SELECT"-Pkt., 15c.; $1 / 4$ oz., $50 \mathrm{c}$

TALI DOUBLE AFRICAN MIXED-Pkt., 10c.; $1 / 4$ oz., 25c.; oz., $75 \mathrm{c}$.

POT MARIGOID and CAPE MARIGOID-See Calendula.

\section{Maurandia Barclayana}

Beautiful climber for either garden or greenhouse; gemmed with Gloxinia-shaped flowers of rich rose. The plants from seed sown in Spring will begin flowering by July and continue until frost. Pkt., 15c.

\section{Mignonette (Reseda)}

A hardy annual, growing 6 to 12 inches high and bearing pyramid-shaped flower spikes made up of thickly set flowers which are exceedingly fragrant. Grows easily from seed and can be transplanted from boxes or sown ont in the garden and thinned to 4 or 6 inches. Sow in the Fall for early blossoms in the Spring. Sowings made in April and again in July will keep up a succession of bloom from early Snmmer till frost; can also be grown in pots for Winter and early spring flowering.

ALLEN'S DEFIANCE-When grown under favorable conditions, spikes will not only be of remarkable size-from 12 to 15 inches long-but deliciously fragrant. The individual florets are of immense size, forming a graceful as well as compact spike. Pkt., 10c.; $1 / 4$ oz., 25c.

GOLIATH "Extra Select"-Enormous red spikes, very fragrant. Pkt., 15c.; $1 / 4$ oz., 50 c.

ORANGE QUEEN-The finest of all Machets, with massive spikes of yellow blossoms. Pkt., 10c.; 1/4 oz., 25c.

GIANT FLOWERED MACHET - Broad heavy spikes closely set with large florets of a gray color, deliciously scented. Pkt., 10c.; $1 / 4$ oz., 25 c.

HALIAWELL'S TRIUMPH-A magnificent new Mignonette of tall-branching habits, sending up numerous large spikes thickly set with brilliant red florets. Unsurpassed for cutting. Pkt., $15 \mathrm{c}$; $1 / 4$ oz., $50 \mathrm{c}$.

SWEET SCENTED (Reseda Odorata) - The spikes are small, but very sweet scented. Pkt., 10c.; oz., 25c.

\section{Mimosa Pudica (Sensitive Plant)}

Curious half hardy anmuals with pinkish white flowers; the leaves close or droop when touched. Sow from February to May in a box and transplant when well started. Pkt., $10 \mathrm{c}$. 


\section{Mimulus}

A free-flowering, half-hardy perennial, growing from 6 inches to 1 foot high. Useful for window gardens and pot work or for garden in a moist shady situation. Blooms first year from seed if sown early.

MOSCHATUS or MUSK PLANT-Sinall yellow blossoms, spotted lightly with brown. Pkt., 15c.

QUEEN'S PRIZE-An improved strain of M. Tigrinus or Monkey Flower. The large flowers are spotted in various colors. Pkt., 15c.

\section{Momordica (Balsam Apple)}

A curious climbing annual, growing 10 feet long, with round, yellow, warted, apple-shaped fruit and glossy leaves. Thrives in warm localities. Plant in late Spring when the ground is warm. Pkt., 10c.

\section{Morning Glory \\ (Convolvulus Major)}

Morning Glories grow quickly to a vine 15 feet long and bear very abundantly, brilliant flowers, funnel-shaped, of various colors, blue predominating. Soak the seed for two hours in warm water to hasten germination; sow late in Spring.

TAIL or CLIMBING VARIETIES-Mixed. Pkt., 10c.; oz., 20c. IMPERIAI JAPANESE-Of gigantic size and in colors ranging from snow-white to carmine, through every shade of blue and purple to nearly black, also marbled, striped and splashed sorts. The vine is not quite so vigorous a climber as the above.

Pkt., 10c.; oz., 25c.

MOONFIOWER-See Ipomoea.

MYOSOTIS-See Forget-Me-Not.

\section{Nemesia}

This free-blooming annual grows about 12 inches. The flowers of this improved strain resemble Calceolarias and come in all shades of purple, pale yellow, white, red, orange, pink and rose, spotted and blotched, making a splendid effect when planted in a bed or border. They are also used as a pot plant. Sow from February to May in boxes and transplant when well started.

STRUMOSA ORANGE-Pkt., 20c.; $1 / 8$ oz., $\$ 1.00$.

STRUMOSA ROSE-Pkt., 20c.; $1 / 8$ oz., $\$ 1.00$.

STRUMOSA SCARLET-Pkt., 20c.; 1/8 oz., \$1.00.

STRUMOSA MIXED-Many beautiful colors. 1 foot tall. Pkt., 15c.; $1 / 8$ oz., 75c.

TRIUMPH MIXED-Compact form. Pkt., 15c.; 1/8 oz., 75c. BIUE GEM-Dwarf blue for edging. Pkt., 20c.; 1/8 oz., \$1.00.

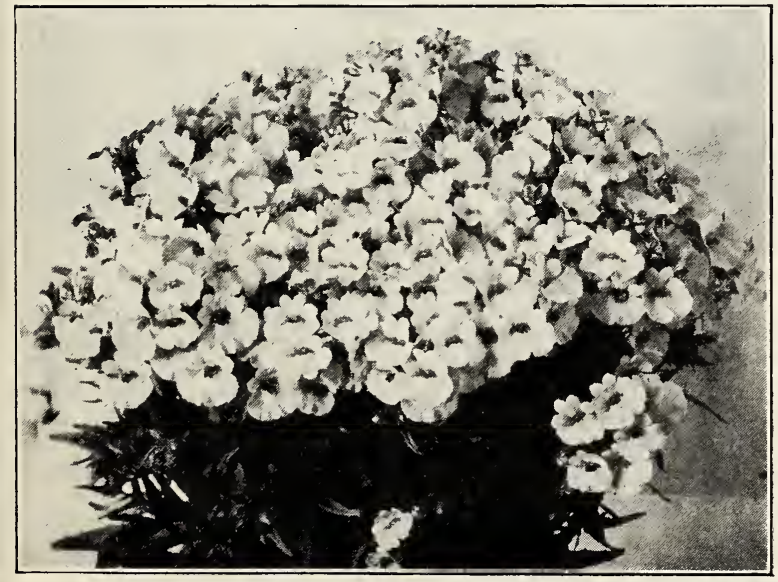

Nemesia Triumph

\section{Nasturtium}

Tender Annuals, in Two Distinct Classes-Tall or Climbing and Dwarf

The foliage of nasturtiums is pretty and the flowers very beautiful and contained in a great number of brightest colors and tints. Sow the seed where it is to remain late in the Spring after danger of frost is over.

It is seldom necessary to thin the young plants, as they will bear standing close together.

Nasturtiums prefer dry, rather rocky soil, such as we usually call "poor" soil, and bear their flowers in such locations in greater profusion than in a rich garden, where they rum too much to leaves. This adds to their value for planting over many unsightly places.

\section{TALL OR CLIMBING VARIETIES}

Of quick growth, covering a wall, hedge or trellis in a short time. The brilliant blossoms almost cover the plant from top to bottom.

CHAMrefeN-Every shade of color, continually changing from day to day. Pkt., 10c.; oz., 20c.; $1 / 4$ lb., $60 \mathrm{c}$.

DARK CRIMSON-Pkt., 10c.; oz., 20c.; $1 / 4 \mathrm{lb} ., 60 \mathrm{c}$.

FULGENS_Dazzling crimson; dark foliage. Pkt., 10c.; oz., 20c.; $1 / 4 \mathrm{lb}, 60 \mathrm{c}$.

GOLD GARNET_Rich yellow, spotted garnet. Pkt., 10c.; oz., 20c.; $1 / 4$ lb., 60c.

ORANGE-Pkt., 10c.; oz., 20c.; I/4 lb., 60c.

PEARI or WHITE-Light lemon or primrose. Pkt., 10c.; oz., 20c.; $1 / 4 \mathrm{lb}$., 60c.

ROSE-Pkt., 10c.; oz., 20c.; I/4 lb., 60c.

SALMON QUEEN-Salmon rose. Pkt., 10c.; oz., 20c.; 1/4 lb., 60c.

SCARLET-Pkt., 10c.; oz., 20c.; 1/4 lb., 60c.

SCHUIZII_Deep scarlet; dark foliage. Pkt., 10c.; oz., 20c.; $1 / 4$ lb., 60c.

YELLOW-Pkt., 10c.; oz., 20c.; 1/4 lb., 60c.

Collection of 6 packets of any of the above tall varieties, $50 \mathrm{c}$.

TAII VARIETIES MIXED-All the above varieties, besides many others, in a splendid mixture. Pkt., 10c.; oz., 15c.; $1 / 4$ lb., 40c.; lb., \$1.25.

TAIL VARIEGATED IEAVED MIXED-Every leaf is variegated with yellow, white and green. The flowers are of all colors. Pkt., 10c.; oz., 25c.

TALI IVY-IEAVED-A mixture of several colors; have lobed or scalloped leaves. The blossoms have scalloped edges. Very pretty and attractive. Pkt., 10c.; oz., 25c.

\section{Nasturtium DWARF VARIETIES}

The plants form a small round bush 12 to 16 inches high, which is a mass of bloom all Summer. Do not water too much nor sow on rich ground for abundance of bloom.

CHAMELEON-Every shade of color, continually changing from day to day. Pkt., 10c.; oz., 20c.; $1 / 4$ lb., 60c.

CRIMSON-Pkt., 10c.; oz., 20c.; $1 / 4$ lb., 60c.

CRYSTAI PAIACE GEM-Sulphur-yellow, spotted maroon. Pkt., 10c.; oz., 20 c.; $1 / 4$ lb., 60 c.

EMPRESS OF INDIA-Deep crimson; fine dark foliage. Pkt., 10c.; oz., 20c.; $1 / 4$ lb., $60 \mathrm{c}$.

GOIDEN KING-Rich golden yellow. Pkt., 10c.; oz., 20c.; $1 / 4$ lb., $60 \mathrm{c}$.

ROSE or PINK-Pkt., 10c.; oz., 20c.; $1 / 4$ lb., 60c.

SCARLET_Pkt., 10c.; oz., 20c.; I/4 lb., 60c.

WHITE PEARI_-Very light lemon or primrose. Pkt., 10c.; oz., 20c.; $1 / 4$ lb., 60c.

Collection of 6 packets of any of the above dwarf varieties, 50 c.

DWARF VARIEGATED IFAVED MIXED-Pkt., 10c.; oz., $25 \mathrm{c}$; $1 / 4 \mathrm{lb}$., $75 \mathrm{c}$.

DWARF VARIETIES MIXED-A splendid mixture of all the above besides many other varieties. Pkt., 10c.; oz., 20c.; I $/ 4$ lb., 50c.; lb., \$1.50. 


\section{Nemophila}

A hardy amnual California wild flower, growing about (i inches high. Has small cup-shaped blossoms in shades of blue and white. Sow in the open gromud in the Fall or spring.

INSIGNIS (Baby Blue Eyes)-Sky blue, with white eyes. Pkt., 10c.; 0z., 30c.; 1/4 1b., \$1.00; 1b., \$3.00.

MACULATA - White with large deep purple blotcls on each petal. Pkt., 10c.; oz., 35c.

MIXED-Pkt., 10c.; oz., 30c.

\section{Nicotiana or Flowering Tobacco}

AFFINIS (Tuberose-Flowered Tobacco) - Delightfully sweetscented, pure white tubular flowers, blooning continually ; half hardy annuals; 2 to 3 feet. Pkt., 10 c.; $1 / 4$ oz., 25 c.

AFFINIS HYBRIDS-A new large flowering type with various bright-colored blossoms. Pkt., 10c.; $1 / 4$ oz., $25 \mathrm{c}$.

SANDERAE-Rosy carmine flowers. Pkt., 10c.

\section{Nigella or Love-in-a-Mist}

A hardy annual, 1 foot high, with finely cut foliage. Oddly shaped blossoms in blue and white, and curious seedpods. Of easy culture.

MUSS JEKYLI_A long-stemmed sort with beautiful cornflower-

blue blossoms. Pkt., 10c.; 0z., 50c.

MIXED COLORS-Pkt., 10c.; oz., 30c.

\section{Oenothera (Evening Primrose)}

LAMARCKIANA - A hardy perennial variety. growing wild in California. The flowers are yellow and 3 to 4 inches in diameter; grows 3 feet tall and succeeds best in a sunny location. Pkt., $10 \mathrm{c}$.

ROSEA MEXICANA-An attractive dwarf annual variety, producing numerous bright rose colored flowers. Height 6 inches. Pkt., 15c.

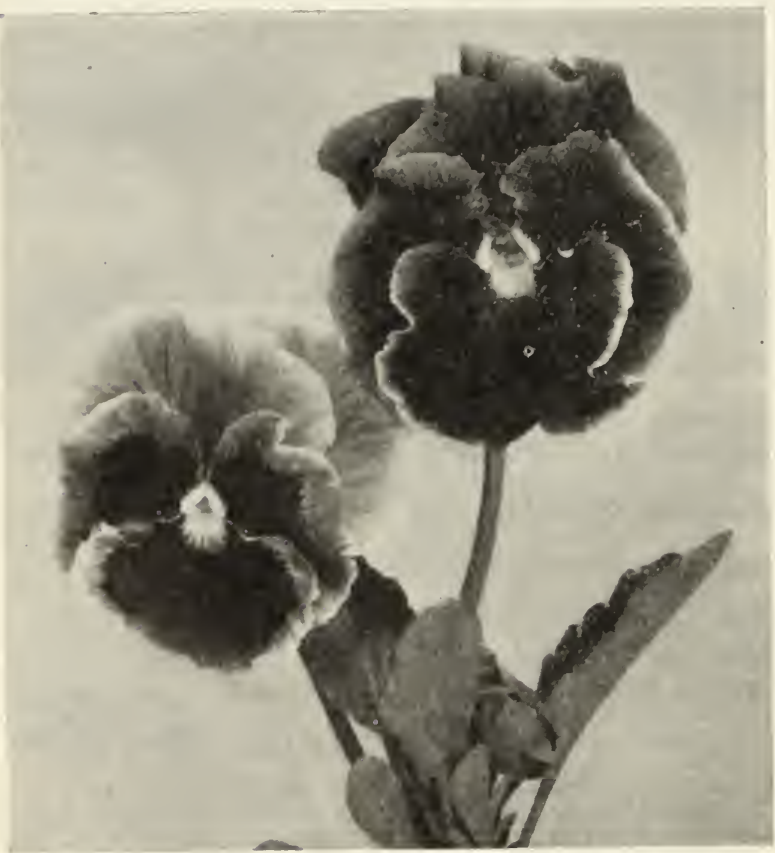

Pansy-Hallawell's Prize Strain

\section{Hallawell's Quality Pansies}

Pansies thrive best in a partially shaded location and in a loose soil, well emriched with decayed manure, which should be well dug into the soil. Seed should be sown in the Fall for early spring blooming and early in the year until May for good flowers later in the Spring and Summer. The seed should be sown in boxes, covering them not more than four times their diameter and firming the soil well above them. Do not allow the seed to dry out. The plants must be transplanted twice in order to get the largest flowers; once from the seed box to a sheltered bed and again to the open ground. For best results, you must start a good strain. The finest pansies are, as a rule, shy seeders, which accounts for the difference in price of the various mixtures offered.

\section{Pansies in Mixtures}

HAILAWELL'S PRIZE STRAIN-This is a mixture of all the giant-flowered varieties, all the plain colors, faced sorts, ruffled edged, and rare sorts; also the varieties exquisitely marbled, striped and blotched. Pkt. of 500 seeds $50 \mathrm{c}$.

BUGNOT MIXED - A ruffled and five-petaled type, with soft, blended colors and tints, veined on the margins and with a dark blotch at the base of each petal. Pkt., $25 \mathrm{c}$.; $1 / 8$ oz., $75 \mathrm{c}$.

CASSIER'S GIANT IMIXED-A splendid mixture of various shades and markings. The blossoms are round and are blotched at the base of the petals. Pkt., $25 \mathrm{c}$.; $1 / 8$ oz., $75 \mathrm{c}$.

IMPERIAI STRAIN MIXED-A fine mixture of choice varieties. Pkt., 25c.; $1 / 8$ oz., $75 \mathrm{c}$.

GIANT MASTERPIECE-These pansies have a combination of rich velvety colors and attractive ruffled petals. Pkt., 25c.; $1 / 8$ oz., $75 \mathrm{c}$.

GIANT PARISIAN, MIXED-A large flowering type of Trimardeau pansies, the top petals are larger than the three lower ones and are beautifully marked; very sweet-scented. Pkt., 15c.; $1 / 4$ oz., $\$ 1.00$.

BEDDING, MIXED-A very good mixture of the smaller-flowering sorts. Pkt., 10c.; $1 / 4$ oz., 65 c.

\section{Giant Flowered Pansies \\ (In Separate Colors)}

GIANT ADONIS-Light blue.

GIANT BIACK.

GIANT BRONZE-Bronze shades.

GIANT CARDINAI_Brilliant red.

GIANT EMPEROR WILLIAM-Dark navy blue.

GIANT FIRE KING-Golden yellow, upper petals crimson.

GIANT GOLDEN QUEEN-Pure golden yellow.

GIANT LORD BEACONSFIELD-Lavender, heliotrope and purple.

GIANT PRINCE HENRY-Rich dark blue.

GIANT SNOWFLAKE-Pure white.

GIANT VICTORIA-Wine red.

GIANT YELLOW KING-Golden yellow with dark eye.

All the above sorts $15 \mathrm{c}$ per pkt., or collection of $6 \mathrm{pkts}$., of any of the above varieties for $75 c$.

\section{Violas or Tufted Pansies}

Very free-blooming hardy peremial plants. Flowers are not so large as in other varieties of pansies, but are procluced in much greater numbers and also bloom for a longer season. Valuable for edging beds and borders.

WHITE PERFECTION-Large white.

LUTEA GRANDIFLORA-Fine yellow.

BLUE PERFECTION-Clear blue, varies in color.

PAPIIO_Lavender with small white eye.

All of the above Violas, pkt., 10c.; $1 / 8$ oz., $50 \mathrm{c}$.

MIXED COLORS-Pkt., 10c.; 1/4 oz., 75c.

APRICOT-Apricot tinged orange towards the center. Pkt., 25c. 


\section{Petunia}

No flower surpasses the Petunia for massing in beds. Their richness of color, duration of bloom, and easy culture will always render them popular. They do well sown in open border in Spring or earlier in the cold frame or hotbed, and transplanted 18 inches apart. By the latter process they will come into bloom much earlier. Be careful not to cover the small seeds too deeply. It is well known that seeds of double varieties do not all produce double flowers, generally about 25 per cent. Save the weaker seedlings, as they usually give the finest double flowers.

\section{SINGLE BEDDING SORTS}

ROSE OF HEAVEN-Brilliant rose-pink, of compact growth. Pkt., $10 \mathrm{c}$; $1 / 8$ oz., $50 \mathrm{c}$.

ROSY MORN-Soft, rosy pink with white throat; compact growth. Pkt., 10c.; 1/8 oz., 50c.

SNOWBAII-Compact growing variety; flowers pure white. Pkt., $10 \mathrm{c}$; $1 / 8$ oz., $50 \mathrm{c}$.

VELVETY BIUE-Rich violet-blue, splendid compact growing variety. Pkt., 10c.; $1 / 8$ oz., 50c.

LARGE-FLOWERED FINEST MIXED-Flowers of very choice colors. large size and free blooming. Pkt., 15c.; 1/4 oz., $75 \mathrm{c}$.; oz., \$2.50.

GOOD MrXED_Pkt., 10c.; 1/4 oz., 40c.; oz., \$1.25.

DWARE INIMITABIE MIXED-A very free-flowering dwarf variety with single cherry-red flowers striped with white Pkt., 10c.; $1 / 8$ oz., $40 \mathrm{c}$.

\section{GIANT SORTS}

RUFFIED GIANTS OF CAIIFORNIA-Most of the flowers are exquisitely fringed on the edges and are very large; the colors are rich and gorgeous and of delicate shades; some have charming deep throats of yellow, white, black, green or maroon; the flowers are of great substance and very deep throated. Pkt., 25c.

GIANT FRINGED PINK-Deep rose pink. Pkt., 35c.

GIANT DOUBIE FRINGED-This strain produces 25 per cent of very large double flowers in all colors, the light shades predominating. Pkt., 50c.

\section{Balcony Petunias}

A splendid free-flowering type either for bedding or window boxes. Flowers average 3 inches across.

BALCONY BLUE-Velvety indigo-blue. Pkt., 20c.

BALCONY ROSE-Brilliant rose-pink. Pkt., 20c.

BALCONY WHITE-Pure white. Pkt., 20c.

BALCONY CRIMSON-Rich velvety crimson. Pkt., 20c.

Collection of a packet of each color for $60 \mathrm{c}$.

BAICONY MIXED-Pkt., 15c.; 1/8 oz., $\$ 1.00$.

\section{Pentstemon}

One of our best flowers for the hardy perennial border; grows 2 feet high; flowers the first season from seed, and blossoms freely. Pentstemon sends up spikes of bright colored and spotted flowers somewhat like the Foxglove, but in a great variety of shades and colors. A decidedly beautiful and satisfactory flower.

GIGANTEUS-New giant variety, largest blooms in many rare shades. Extra fine strain. Pkt., 25c. GIANT PINK SHADES - Shades of carmine, rose and pink. Pkt.,
25c.

FINE MIXED-Pkt., 10c.

\section{Phacelia Campanularia}

A hardy California wild flower. The saucer-shaped flowers are a beautiful clear deep blue color, with contrasting white stamens and are produced in remarkable profusion. Sow the seed in the open either in the Fall or Spring. Pkt.., 10c; I/4 oz., $30 \mathrm{c}$.

\section{Physalis Francheti}

\section{(Chinese Lantern Plant)}

Ornamental plants growing 2 feet high with large pointed seed pods, which are yellow and change to a brilliant scarlet in the Fall. Tender annual. Pkt., 10c.

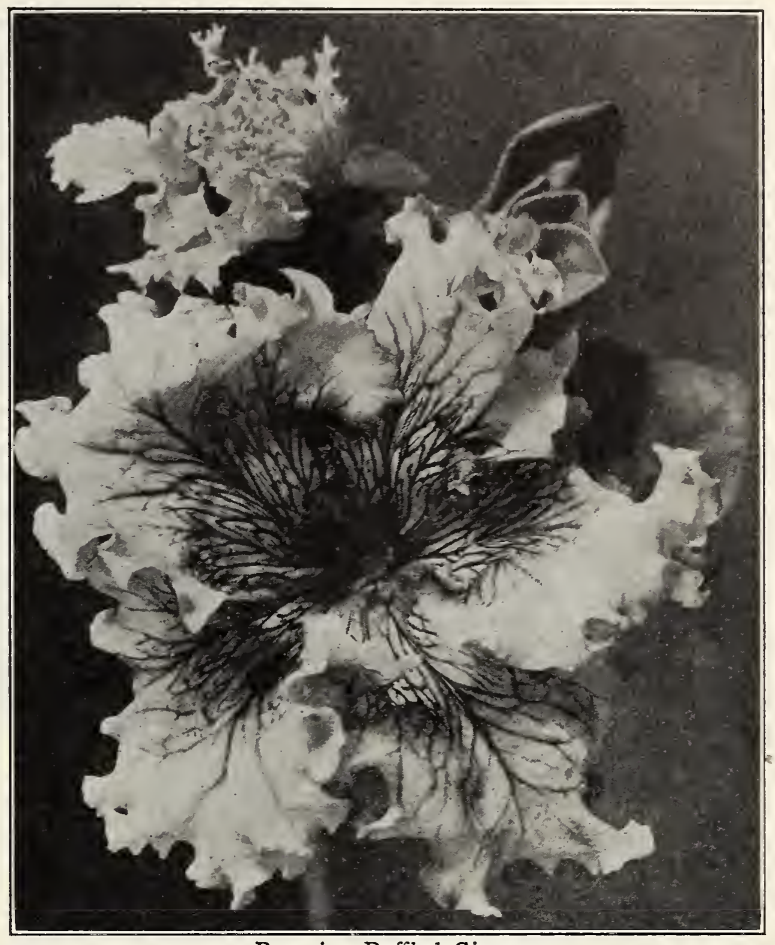

Petunia-Ruffled Giants

\section{Physostegia}

(False Dragon Head)

A very pretty, hardy perennial, forming a dense bush 2 feet high and bearing freely during the Summer, leafless spikes of tubular flowers.

VIRGINICA-Strong spikes of lilac-pink flowers. Pkt., 15c. VIRGINICA ALBA-Large white flowers. Pkt., 15c.

\section{Platycodon}

(Chinese Bellflower)

GRANDIFLORUM-A handsome hardy perennial which thrives in a light dry situation; with large steel-blue bell-shaped flowers on spikes 2 feet tall. Will bloom first year if sown early. Pkt., $10 \mathrm{c}$.

\section{Portulaca}

A creeping annual with thick stems and foliage; bearing brilliant colored cup-shaped flowers during the entire Summer. This plant is suitable for rockeries and banks and will grow and bloom profusely in a dry, hot situation. In sowing, mix the seed with dry sand to insure an even distribution. Sow in late Spring when the ground is thoroughly warmed up.

GOIDEN YELLOW, WHITE, SCARLET-Any of the above. Pkt., 10c.; $1 / 4$ oz., $30 \mathrm{c}$.

SINGLE MIXED-A large variety of the most brilliant colors. Pkt., 10c.; $1 / 4$ oz., $25 \mathrm{c}$.

DOURLE MIXED-The most brilliant shades and choice flowers. Pkt., 10c.; $1 / 4$ oz., $75 \mathrm{c}$.

\section{Potentilla (Cinquefoil)}

Hardy perennial border plants with handsome strawberry-like foliage and of free blooming habit, continuing in bloom from Spring until Autumn. The flowers run mostly in shades of maroon, scarlet and orange, often beautifully banded with yellow. Height $11 / 2$ to 2 feet.

FINE SINGLE MIXED-Pkt., 15c.; I/4 oz., $65 \mathrm{c}$.

NEWEST DOUBLE HYBRIDS MIXED-Pkt., 25c. 


\section{Phlox Drummondii Grandiflora}

For beds and massing notling (anl surpatss these beatutiful atmuals. They proeluce immense trusses of large. brilliant flowers of numberless hues throughout the summere. This strain has bealutiful round petaled flowers, larger than in the older sorts; showy and constant. suw the seed in boxes in the Fall for earty flowers, or in the open in spring. anel thin to ti inches.

CARNEA-Pale pink with rose center. Pkt., 10c.;

CHAMOIS ROSE-Deep pink with yellow center.

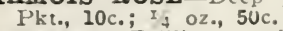

COCCINEA-Brilliant scarlet. Pkt., 10c.; $1 / 4$ oz., 50c. KERMESINA-Vivid crimson. Pkit., 10c.; $1 / 4$ oz., buc.

PURE WHITE Pkt., 10c.; $1 / 4$ oz., 50c.

SOF.S IIUAC-Pkt., 10c.; 1; oz., 50c.

YELLOW (Isabellina) - Frmmrose. Pkt., 10c.; I/4 oz., 50c.

Collection of a packet each of the above seven sorts, 60c.

FINE NIIXED-A choice mixture of all colors of the larger types. Pkt., 10c.; $1 / 4$ oz., 4uc.; oz.,

CUSPIDATA - Starrel and fringed. Mixed. Pkt., 10c.; I/4 Oz., $40 \mathrm{c}$. PINKS'-See Dianthus.

\section{Annual Poppies}

Annual Poppies should be sown in the open ground where they are to remain, as they do not stand transplanting. sow very thinly, mixing the seed with dry sand to aroid getting too thick; barely cover the seed and press down firmly. If they come up too thickly, they must be thimed out to stand 3 to $t$ inches or more apart. Seed may be sown any time from September to June.

SELECT SHIRLEY - This is an extra fine strain of these charm-

ing Poppies, containing the greatest variety of colors, of

White, delicate pink, deep crimiso
Pkt., 10c.; 0z., 40c.; $1 / 4 \mathrm{lb}$., $\$ 1.25$.

THE SHIRLEY - Rose Pink. Pkt., 10c.; I/4 oz., 30c.

THE SHIRLEY - Deep apricot. Pkt., 10c.; $1 / 4$ oz., 30c.

howy, thin, crinkly petals containing many new salmon shades. Mixed colors. Pkt., 10c.; $1 / 4$ oz., 25c.

TULIP FLOWERED - Intense scarlet, single blossoms. Plants

about $21 / 2$ to 3 feet high. The brightest colored of all poppies. CARNATION FLOWERED MIXED-Large double fringed; all

PAEONY FLOWERED MIXED-Large, double straight edged;

\section{Perennial Poppies}

Hardy perennial of easy culture; in bright, glowing colors. Sow seed preferably in the fall or early spring, in boses or the opene groment and transplant when of suitable size.

ICELAND_A graceful, delicate variety, 12 inches tall, with white, orange and yellow single blossoms, the petals resembling flowers on their slender talks are excellent for cutting. Blooms

the first year from seed if sown early in the spring.

ORANGE, WHITE or YELLOW-Pkt., 10c.

NEW HYBRIDS, MIXED-Pkt., 15c.

SUNBEAM IMPROVED MIXURE-Lring stems and large Howers in many new sharles. Pkt., 25c.

GIAN I TANGERINE-Russet-orange; blooms of large size. Pkt., OrIENTALE (The Large Oriental Poppy)-A charming Summer flowering harcly plant, producing numerous leafy stems
about $2 \frac{1}{2}$ feet high, with large orange-scarlet flowers, having a conspicuous black blotch on each petal; exceedingly showy. ORIENTALE BEAUTY OF LIVERMERE-Crimson with black ORIENTALE PRINCESS VICTORIA LOUISE-Salmon. Pkt.,
15c.

ORIENTALE HYBRIDS-A splendid mixture of all shades. Pkt.,

10c.; $1 / 4$ oz., 50 c.

\section{Primula Obconica}

These are of the easiest culture in the greenhouse and also suceed well in the open border during the Summer. The seed should be sown in good porous loam; they will not germinate well in any compost containing peat or leaf mould. If sown in February or Mareh will bloom the same year.

OBCONICA GRANDIFLORA MIXED - Very free flowering.
Pkt., 15c.

OBCONICA GIGANTEA-An improved type of the above sort. Crimson, pkt., 25c.; Lilac, pkt., 25c.; Rose, pkt., 25c.; Mixed,
pkt., 25c.

\section{Various Primroses}

AURICULA - The Primrose of the Alps. Flowers variously colored; fragrant. Seed selected from prize flowers. Pkt., 25c. JAPONICA (Japanese Primrose)-Bright and showy flowers borne in whorls on stems about 6 inches long. Pkt., 15c.

MALACOIDES-Small, light-lilac flowers; very early and profuse bloomer. If sown in January or February will commence flowering from May to July, while by sowing in August a fine display of bloom can be obtained during the winter months. Pkt., 15c.

MALACOIDES SUPERBA-A new and improved variety; color is deep rosy pink. Pkt., 25c.

POLYANTHUS-A hardy sort, blooming early in the open gardens. Colors mostly red and yellow. Extra Choice Mixed. Pkt.,

POLYANTHUS GIANT MUNSTEAD STRAIN-Flowers of the largest size in wonderful shades of yellow, from cream to rich orange, also pure white and charning "eyed" flowers. Pkt., $15 \mathrm{c}, 1 / 8$ oz., $75 \mathrm{c}$

POLYANTHUS YELLOW-Golden yellow. Pkt., 25c.

VULGaris-The true yellow English Primrose. Pkt., 15c.; $1 / 8$ oz., $75 c$. 


\section{Pyrethrum}

PARTHENIFOLIUM AUREUM, OI GOLDEN FEATHER -Small cut leaves of bright golden yellow. A hardy perennial, with bright foliage, much used for edging and borders. Seed can be sown in the Fall or Spring and transplanted. Pkt., 10c.; $1 / 4$ oz., 25 c.; oz., 75 c.

SELAGINOIDES-Foliage bright golden yellow, finely serrated; fine for borders and edging. Pkt., 10c.; $1 / 4$ oz., $35 \mathrm{c}$.

HYBRIDUM GRANDIFLORUM-Large flowering single mixed, hardy perennial, bearing large Daisy or Cosmoslike flowers, ranging in color from light pink to deep red, with bright yellow centers; blooms in May and June and again in the Fall, and is one of the most graceful and long-lasting cut flowers; 2 feet. Pkt., 15 c.

HYBRIDUM FI. PI.-Seeds saved from the finest double flowers; only a small percentage can be expected to come double the first year; mixed colors. Pkt., 25c.

\section{Ranunculus}

These late Spring-blooming plants grow about 9 inches high and should be planted in a cool, partly shaded position. The flowers are double and semidouble and come in a very wide range of attractive colors. Sow the seed outdoors from April to June for next Spring's bloom and keep shaded until plants appear. Superb mixture. Pkt., 15c; r/4 oz., 50c.

\section{Rehmannia Angulata}

A half-hardy herbaceous perennial with beautiful large rosy-purple gloxinia-like flowers. Suitable for pot culture or outdoors in a sheltered situation; 3 feet tall. Sow in boxes to transplant. Pkt., 25c.

\section{Rhodanthe}

(Everlasting Flower)

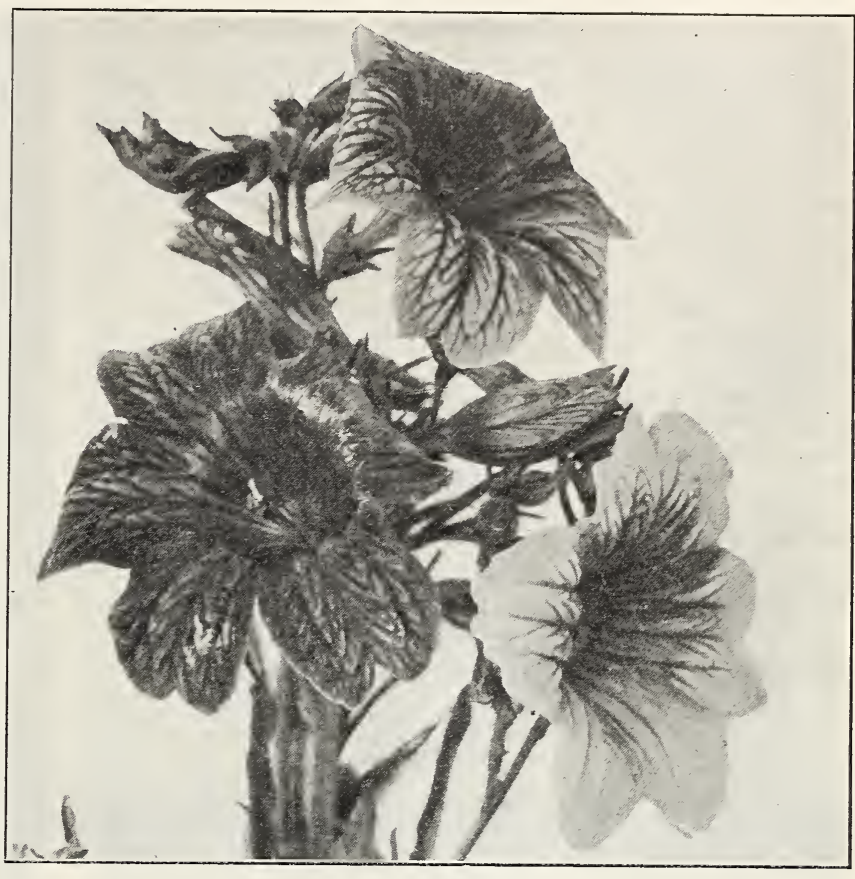

Salpiglossis

One of the finest and most beautiful of the many varieties of Everlasting; for Winter bouquets, the blossonis should be gathered before fully expanded, and if dried in the shade will retain their brilliancy for years. Pink, White or Mixed. Pkt., 10c; 1/4 0z., 30c.

RICrNus-See Castor Bean.

\section{Rudbeckia (Cone Flower)}

BICOIOR SUPERBA-Fine, free-flowering annual variety, growing about 2 feet high, forming a dense bush and producing in great abundance on long stems its bright flowers. The disc is brown, the florets golden yellow with large, velvety-brown spots at the base; very effective and useful for cutting. Sow the seed from February to May. Pkt., 10c.

PURPUREA GRANDIFIORA-A perennial variety with large handsome crimson-purple flowers with dark central disc; 3 feet high. Pkt., 15c.

\section{Salvia or Flowering Sage}

The scarlet Sage has long been a favorite bedding plant, bearing long spikes of flowers in great profusion from July till frost; half-hardy perennials, blooming the first year from seed, which should be sown as early as possible either indoors or in a hotbed, and the young plants transferred to their flowering quarters when the weather has become settled and warm.

SPLENDENS (Scarlet Sage)-Beautiful bright scarlet; 3 feet. Pkt., 10c.; $1 / 4$ oz., 75c.

FIREBAIs_-This is one of the finest of the Scarlet Sages, growing in a compact bush 18 inches high. Its erect spikes of flowers of brilliant red stand clear above the dark-green foliage and completely cover the plant. Pkt., 15c.; $1 / 8$ oz., $50 \mathrm{c}$.

PATENS (Blue Sage)-In color this is as blue as the "Scarlet Sage" is red; unlike the latter, however, it is not useful for bedding, but is a beautiful plant for the border or greenhouse; half hardy perennials; 2 feet. Pkt., 25 c.

FARINACEA-A hardy perennial variety but best grown as an annual. The bright light-blue flowers are borne on long spikes held well above the foliage. Blooms from July until frost; 2 to 3 feet. Pkt., 15c.

AZURFA GRANDIFLORA-A hardy perennial variety growing 3 to 4 feet and producing during late summer, panicles of pretty sky-blue flowers in great profusion. Pkt., 15c.

\section{Salpiglossis}

A half-hardr annual, growing about 3 feet high and bearing trumpet-shaped blossoms of rich shades and colors, all beautifully veined. It is valuable for bedding and massing, and its long stems make it excellent also for cut flowers. Sow seed early in the Spring and transplant, or sow the seed where it is to remain, in April, and thin to 6 or 8 inches. Enrich the soil.

PURPLE and GOJD, ROSE and GOLD, VELVETY RED, BROWN and GOID, IIGHT BIUE and GOID, SCARIET and GOLD. Any of the above colors, 10c per pkt.

Collection of 6 sorts, 50c.

EMPEROR-A splendid large flowered strain; each stem is loaded with these most handsome flowers; each one richly veined with gold. Mixed colors. Pkt., 10c.; 1/4 oz., $50 \mathrm{c}$.

\section{Saponaria (Bouncing Bet)}

OCYMOIDES-A handsome dwarf trailing plant with bright rose colored flowers. Suitable for rock work or borders. Hardy perennial. Pkt., 10c.

VACCARIA-A pretty and useful annual variety, bearing an abundance of satiny pink flowers somewhat like an enlarged Gypsophila; fine for cutting: 2 feet tall. Sow in the open at intervals for a succession of bloom. Pkt., 10c.; oz., 30c.

\section{Sanvitalia Procumbens Fl.Pl.}

An excellent annual edging plant growing 6 inches high, with small double yellow flowers produced in abundance all Summer. Pkt., 10c.

\section{Sidalcea, Rosy Gem}

A handsome herbaceous perennial producing numerous miniature Hollyhock-like spikes of a pretty, clear rose shade. Height 4 feet. Pkt., 15c. 


\section{Scabiosa}

Sow the seed any time in the Fall or Spring, either in boxes to transplant or in the open ground. Scabiosas grow about 3 feet high, and come into bloom early in July, and continue without interruption until hard frost. The beautiful flowers in exquisite shades are borne on long stens, and when cut keep in perfect condition for the best part of a week. They make effective borders or beds. We ofler 6 beatiful colors as under:

\section{IMPROVED LARGE FLOWERING}

AZURE FAIRY-Lavender-blue. Pkt., 10c.; $1 / 4$ oz., $30 \mathrm{c}$.

CRIMSON-Pkt., 10c.; $1 / 4$ oz., 30c.

FLESH PINK-Pkt., 10c.; $1 / 4$ oz., 30c.

KING OF THE BLACKS-Black purple. Pkt., 10c.; $1 / 4$ oz., 30c. ROSE-Pkt., 10c.; $1 / 4$ oz., 30c.

WHITE-Pkt., 10c.; $1 / 4$ oz., 30c.

Collection of 6 sorts for 50c.

MrXED-All colors of the Improved Large-Flowering. Pkt., 10c.; $1 / 4$ Oz., 20c.; Oz., 60c.

For novelties in Scabiosa, see specialty page $2 \delta$.

\section{HARDY PERENNIAL SORT}

CAUCASICA (Blue Bonnet)-One of the handsomest of hardy perennials, especially valuable for cutting, the blooms lasting in a hotbed from November until February as the seed loses its vitality when a few months old. Pkt., $15 \mathrm{c}$.

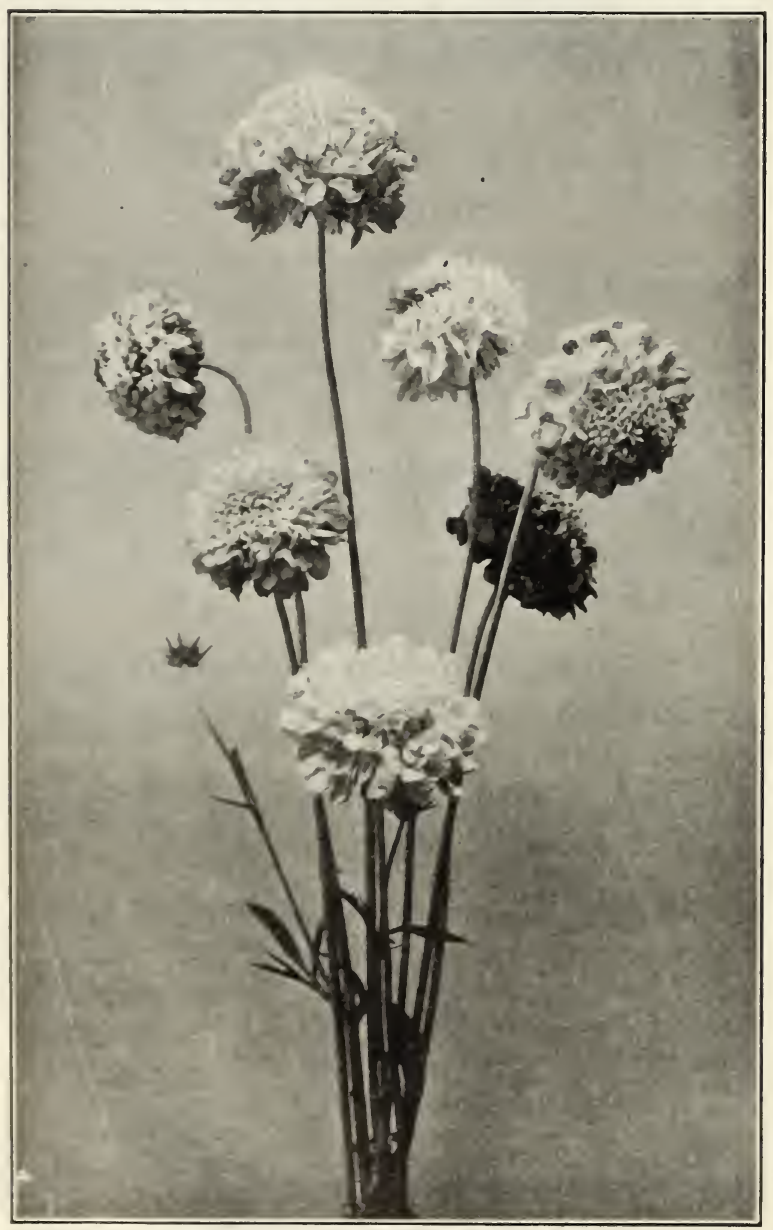

Scabiosa, Large Flowering, Mixed

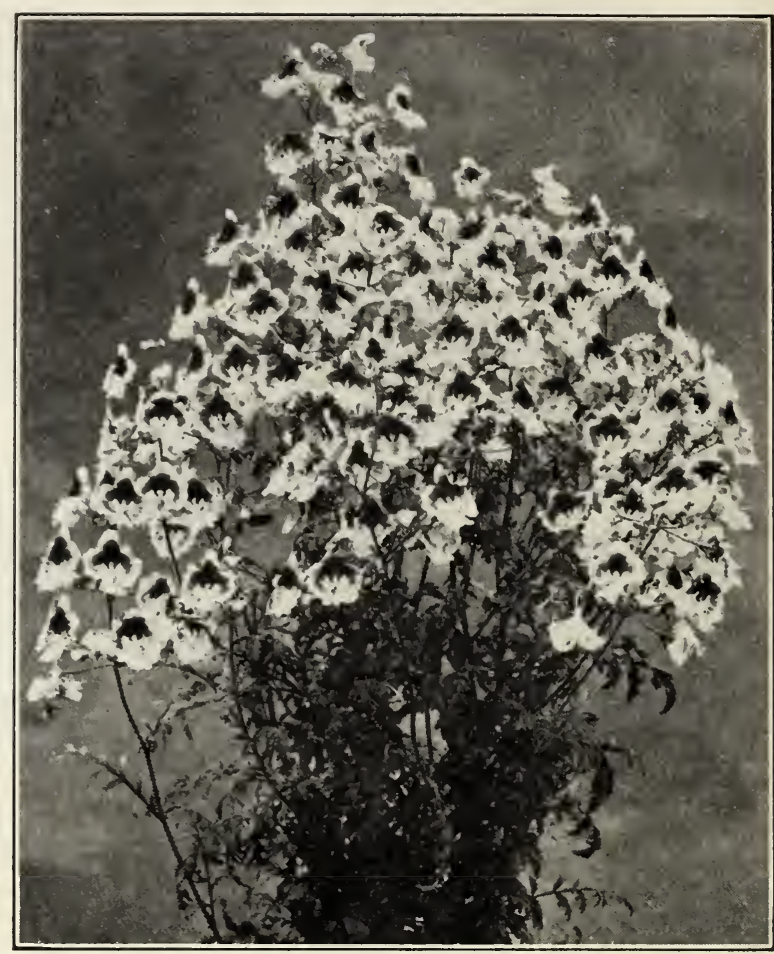

Schizanthus-Garraway's Hybrids

\section{Schizanthus}

(Poor Man's Orchid)

An easily grown plant, bearing quantities of beautiful Orchid-like flowers in a bewildering range of color. The plants are such profuse bloomers that each plant looks like an immense panicle of lovely blossoms. May be sown in April in the open ground where they are to remain. A sowing niade in Autumn putting 3 to 5 plants in a 6 -inch pot, will give an abundance of bloom through the Winter.

GARRAWAY'S HYBRIDS-This strain is superior to all other varieties of Schizanthus, the flowers being larger and better shaped, showing a wide range of colors in shades of yellow, brown, apricot, mauve, purple, pink, crimson, etc. They make splendid pot plants and are very useful in the flower border as the plants are compact and bushy. Pkt., 25c.

MAUVE and PURPLE SHADES-Pkt., 25c.

ROSE and PINK SHADES-Pkt., 25c.

ROSE and AMBER SHADES-Pkt., 25c.

WISETONENSIS (Excelsior Strain)-This variety is now largely used as a pot plant for the house or conservatory. It is remarkably free flowering, and presents a beautiful appearance with its myriads of blooms in a large range of brilliant colors. Pkt., $25 \mathrm{c}$.

GRANDIFLORUS-An extra select mixture of the regular type. Pkt., 10c.; $1 / 4$ oz., 30c.

\section{Silene Pendula (Catchfly)}

Pretty dwarf plants used mostly for borders, growing 6 inches high. A hardy annual, which is easily grown. Sow the seed in the Fall or Spring.

WHITE-Pkt., 10c.; $1 / 4$ oz., 25c. RED-Pkt., 10c.; $1 / 4$ oz., 25c. PIN K-Pkt,. 10c.; $1 / 4$ oz., 25c. MIXED-Pkt., 10c.; $1 / 4$ oz., $25 \mathrm{c}$; oz., $75 \mathrm{c}$.

\section{Smilax}

A climbing perennial, with beautiful bright-green, glossv leaves, much esteemed for its loug, delicate sprays of foliage. Largely used for decorating. Start seed under glass and transplant 6 inches apart. It requires strings or wires to climb on when very young. Pkt., $10 \mathrm{c} ; \mathrm{I} / 4$ oz., $25 \mathrm{c} ; \mathbf{0 z}$., $75 \mathrm{c}$. 


\section{Snapdragons (Antirrhinum)}

Snapdragons are one of the best cut flowers which can readily be growu from seed, while for beds or borders they are a constant source of pleasure, being in flower all the time. They succeed best in a rather light soil, in a sunny position, and although perennials, are best treated as annuals. For early flowering, sow in Fall, protecting the plants from frost; sown in Spring, they bloom from mid-Summer till frost.

\section{TALL, LARGE FLOWERING TYPE 24 to 30 inches tall.}

GIANT CRIMSON KING-Rich crimson. Pkt., 10c.

GIANT FIRE KING-Orange-scarlet, white tube. Pkt., 10c. GIANT GOLDEN IING-Clear yellow. Pkt., 10c.

GIANT HARMONY-Terra cotta pink, buff lip. Pkt., 10c.

GIANI QUEEN VICTORIA Pure white. Pkt., 10c.

GIANT CORAL ROSE-Coral-rose. Pkt., 10c.

GIANT ROSE QUEEN-Soft pink. Pkt., 10c.

GIANT TORCHLIGHT_Orange with yellow lip. Pkt., 10c.

Collection of 6 packets of any of the above varieties for 50c.

GIANT MIXED-A splendid mixture, containing all the colors; magnificent spikes of large individual flowers. Pkt., 10c.; . $1 / 4$ oz., 30 c.

\section{INTERMEDIATE, LARGE FLOWERING TYPE}

Growing 18 to 24 inches tall. The best for bedding purposes. AMBBER QUEEN-Amber, suffused chamois pink. Pkt., 10c.

GOLDEN QUEEN-Clear yellow. Pkt., 10c.

DEFIANCE-Orange or russet red. Pkt., 10c.

EMPRESS-Rich velvety crimson. Pkt., 10c.

GOLDEN O,UEEN-Clear yellow. Pkt., 10c.

NELROSE-Deep rose-pink. Pkt., 10c.

PINK PERFECTION-Pink slightly suffused with salmon. Pkt., 10c.

PRIMA DONNA-Terra cotta pink with white tube. Pkt., 10c. PURITY-Pure white. Pkt., 10c.

ROSE DORE-Coral rose, suffused orange. Pkt., 10c.

SILVER PINK-Beautiful pearly pink. Pkt., 10c.

Collection of 6 packets of any of the above sorts for 50c.

LARGE INTERMEDIATE MIXED-An extra select strain containing the very best varieties. Pkt., 10c.; $1 / 4$ oz., 50c.

\section{MAXIMUM TYPE}

This wonderful new group of Snapdragons far surpasses anything yet introduced. In habit they are slightly taller than the tall group. The flowers are of magnificent size closely placed on the spike. The group as a whole is slightly variable in size and color.

APPLE BLOSSOM-Rosy pink, white tube. Pkt., 15c.

CANARY BIRD-Canary yellow. Pkt., 15c.

COPPER KING-Bronzy-copper. Pkt., 15c.

CRIMSON KING-Deep garnet. Pkt., 15c.

OID GOLD-Deep golden yellow. Pkt., 15c.

SNOWFLAKE-Pure white. Pkt., 15c.

THE ROSE-Rose pink. Pkt., 15c.

Collection of the above 7 sorts for $85 c$.

MAXIMUM_All colors mixed. Pkt., 15c.; 1/4 oz., 65c.

\section{Statice (Sea Lavender)}

Splendid hardy annuals, either for the border or rockery, producing all Summer panicles of small flowers which can be dried and used for Winter bouquets. Start the seed under glass, as it is difficult to germinate.

ROSEA SUPERBA-New, beautiful shades of pink. Pkt., 10c. ATROCOERULEA-New dark blue. Pkt., 10c.

WHITE-Pkt., 10c.; YELLOW-Pkt., 10c.; MIXED-Pkt., 10c. SUWOROWII-A hardy annual variety producing long spikes of bright rose-colored flowers. Pkt., 15c.

LATIF OIIA - A hardy perennial variety with large branching heads of clear mauve flowers. Invaluable for the perennial border as well as for drying. Pkt., 10c.

CASPIA_One of the finest of the many varieties. Smaller flowers than Latifolia and of more delicate appearance in bouquet work. Color, pale lavender. Pkt., 15c.

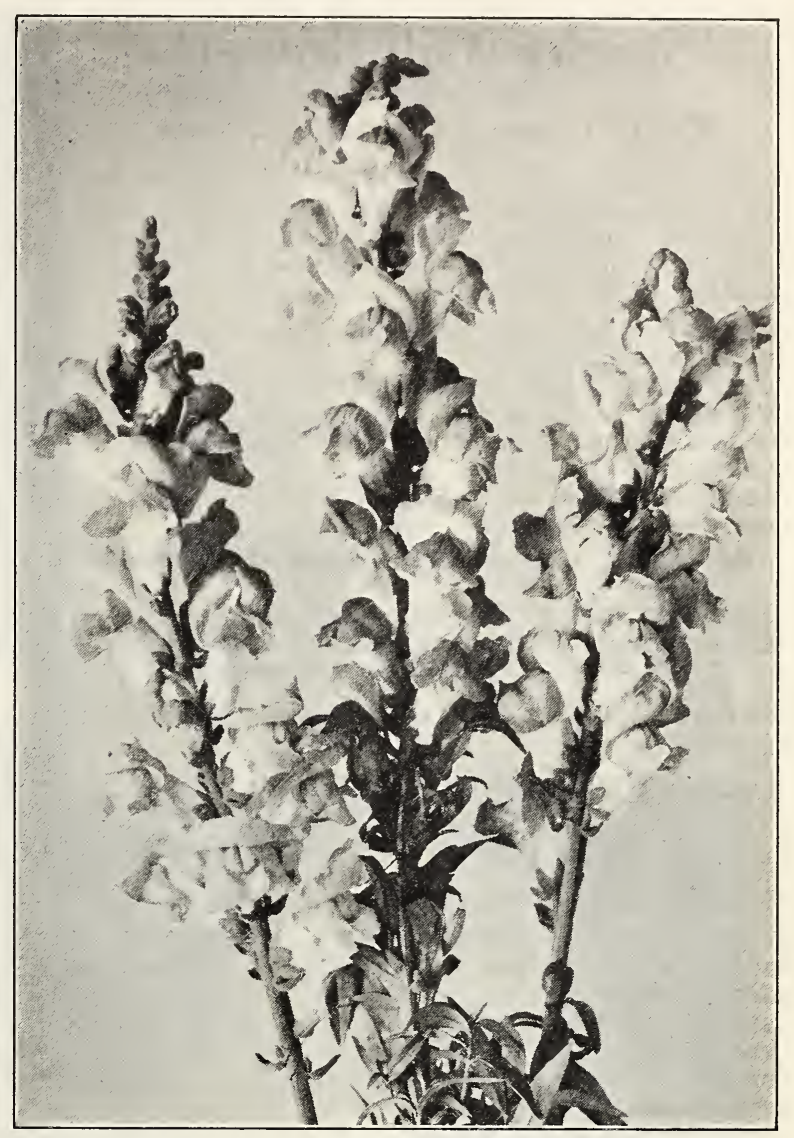

Snapdragon, Intermediate, Large Flowering

\section{Solanum (Jerusalem Cherry)}

COVENT GARDEN STRAIN-Popular for house decoration. Compact bushy dark green foliage; small white flowers, followed by bright scarlet berries; 1 foot tall. Pkt., 10c.

\section{Stevia Serrata}

The tiny white flowers are produced in long, loose panicles. Fine for cutting. Hardy perennial, growing 2 feet tall. Pkt., 15c; $1 / 8$ oz., 40 c.

\section{Streptocarpus}

Novel free-blooming greenhouse pot plants, remaining in bloom for a long period. Finest Hybrids-Mixed, Pkt., 50c.

\section{Sunflower (Helianthus)}

Tender annuals, growing from 3 to 8 feet high. Of the easiest culture and suitable for a stately row or background. Plant when the ground is well warmed, in light soil.

CHRYSANTHEMUM FLOWERED - Large, densely double, bright golden flowers. The plant branches and affords fine, long stout stems for cutting. 4 feet. Pkt., 10c.; oz., 40c.

CUCUMERIFOLIUS STFLLA-Of dwarf branching habit; grows about 3 feet high and blooms profusely throughout the Summer; flowers single orange-yellow, with black center. Pkt., 10c.; $1 / 4$ oz., $20 \mathrm{c}$.

CUCUMERIFOIIUS PERKrO-The plants form compact bushes about 18 inches high and are covered with small yellow blossoms with dark eyes all Summer. Pkt., 10c.; $1 / 4$ oz., $25 \mathrm{c}$.

RED SUNFLOWFR-Some flowers are a rich chestnut-red color, others tipped with yellow and others slightly washed with red. The flowers vary in size, some being very large. Plants grow from 4 to 8 feet tall. Pkt., 10c.; $1 / 4$ oz., $20 \mathrm{c}$. 


\section{Stocks (Gilliflower)}

\section{Early Giant Imperial Stocks}

All especially fine strain of Summer Stocks. Growing from twent $y$-four to thirty inches tall; of branching habit. Yery free blooming and prodnces a high percentage of double flowers. Splendid for cutting; equally suitable for bedding.

CHAMOIS-Ivory, tinted old rose. Pkt., 15c.

DARK BLUE-Pkt., $15 \mathrm{c}$.

FIERY BLOOD RED-Pkt., 15c.

FLESH-Delicate pink. Pkt., 15c.

GOLDEN BALI-Light canary yellow. Pkt., 15c.

LAVENDER-Pkt., $15 \mathrm{c}$.

ROSE_Deep rose pink. Pkt., 15c.

WHITE-Pkt., 15c.

Collection of 6 packets of any of the above varieties for $75 \mathrm{c}$.

CHOICEST MIXED-Pkt., 15c.; I/8 oz., 60c.

GOLDEN ROSE-A rich light rose enhanced by a pleasing golden effect in the center of each individual floret. Pkt., $25 \mathrm{c}$.

ANTIQUE COPPER - Rich Hellebore-red, overlaid with copper. Pkt., 25c.

\section{Large Flowering 10-Week Stocks}

This is the leading class for bedding out for Summer blooming. Sow the seed in Spring in boxes or hotbed and transplant to 1 foot apart. Save weaker seedlings as they generally produce double flowers. BLOOD RED-Pkt., 10c.

IIGHT BLUE-Pkt., 10c.

BRIGHT PINK-Pkt., 10c.

FLESH PINK-Pkt., 10c.

PURPLE-Pkt., 10c.

PURE WHITE-Pkt., 10c.

CANARY YELLOW-Pkt., 10c.

Collection of the above 7 sorts, 60c.

MIXED-Double large-flowering. Pkt., 10c.; 1/8 oz., 50c.

\section{Giant Perfection Stocks}

An improved trpe of Mammoth Nice Stock under which name we formerly listed them. A splendid class that can be used for summer flowering but for Winter flowering is most raluable. Ther form much branched plants and have numerous spikes of large double flowers. For Winter bloom sow from June to August.

GIANT PERFECTION PINK (Abundance)-Lavender-pink. GIANT PERFECTION FLESH (Beauty of Nice) GIANT PERFECTION OLD ROSE (Belle de Naples) GIANT PERFECTION CRIMSON (Crimson King)

GIANT PERFECTION HEATHAM BEAUTY-Rose shaded terra-cotta.

GIANT PERFECTION PALE BLUE (May Queen) GIANT PERFECTION WHITE (Mont Blanc)

GIANT PERFECTION YELLOW (Monte Carlo)-Pale yellow. GIANT PERFECTION LAVENDER (Parma Violet)

GIANT PERFECTION DARK BLUE (Summer Night)

Any of the above varieties, pkt., 15c.; 6 pkts. for 75c.

GIANT PERFECTION MIXED-Pkt., 10c.; I/8 oz., $50 \mathrm{c}$.

\section{Winter Stocks}

EMPRESS ELIZABETH-A very handsome stock. Grows about 20 inches high, has numerous spikes of carmine-pink, double
flowers and is extensively used for bedding as well as for cutting purposes. Pkt., 15c.

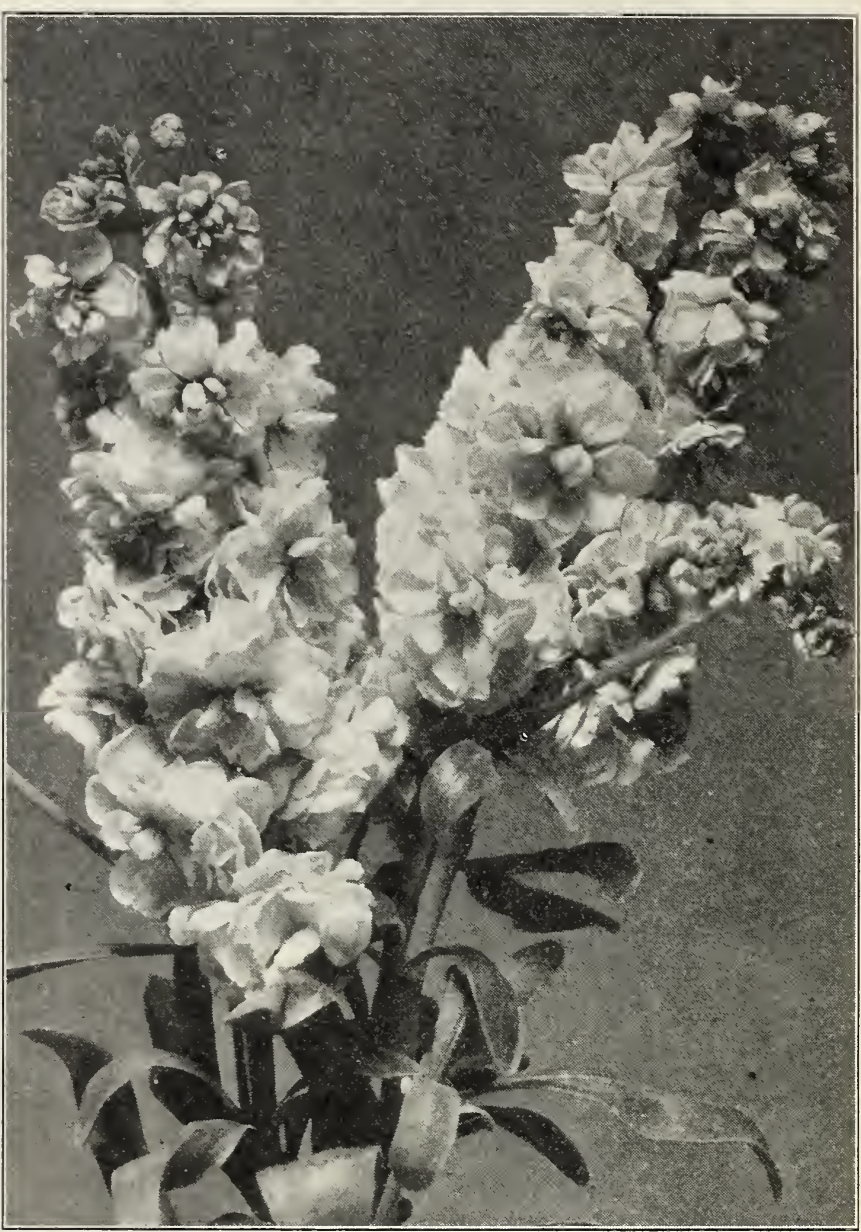

Stocks, Early Giant Imperial

\section{Stokesia (Cornflower Aster)}

A beautiful hardy perennial growing about 2 feet high bearing 20 to 30 lavender cornflower-like blossoms. Pkt., $10 \mathrm{c}$.

\section{Sweet Rocket (Hesperis)}

Hardy perennial, growing 2 to 3 feet, bearing spikes of fragrant purple and white flowcrs. Mixed. Pkt., 10c.; oz. 60c. SWEET SULTAN-See Centaurea Imperialis.

\section{Sweet William}

A very desirable low-growing, free-flowering hardy perennial, producing a splendid effect in beds and borders with their rich and varied flowers.

SINGLE WHITE-Pkt., 10c.; $1 / 4$ oz., $25 \mathrm{c}$.

SINGLE CRIMSON SHADES-Pkt., 10c.; $1 / 4$ oz., $25 \mathrm{c}$.

SINGLE VELVET MAROON-Pkt., 10c.; $1 / 4$ oz., $25 \mathrm{c}$.

SINGLE NEWPORT PINK-Brilliant salmon-rose. Pkt., 15c.; $1 / 4$ oz., $60 \mathrm{c}$.

SINGLE SCARLET BEAUTY-Bright scarlet. Pkt., 15c.; 1/4 oz., $60 \mathrm{c}$.

SINGLE MIXED_Pkt., 10c.; $1 / 4$ oz., 25c.; oz., $75 \mathrm{c}$.

GIANT DOUBLE MIXED-Pkt., 10c.; $1 / 4$ oz., $50 \mathrm{c}$.

HOLBORN GLORY-This strain is a large-flowered selection of the auricula-flowered section. This variety contains a beautiful strain of light shades. Pkt., 10c.; $1 / 4$ oz., $30 \mathrm{c}$.

Collection of 6 varieties, 50c. 


\section{HALLAWELL SEED CO.

\section{Spencer or Orchid Flowered Sweet Peas}

Work the soil at least 18 inches deep, 2 feet is better, with plenty of rotten stable manure. Cow manure is the best; use some lime and crushed bone. Tramp the soil down firmly; never plant in loose soil. Take the hose and water down to the base. Let stand a few days until moderately moist. NEVER PUT THE SEED IN TOO WET SOIL. Rake off the surface nice and smooth, make rows and drop seed not orer $t$ wo inches deep, and two inches apart. Rake off again. DO NOT WATER UNTIL ALL THE SEED IS UP, AT LEAST HALF AN INCH OUT OF THE SOIL. (Nine-tenths of the failures are caused by watering too soon). Thin out to at least six inches apart and train on wire netting or string when plants are five or six inches high. Applications of liquid manure during flowering period will add to the length of stems and size of blossoms.

\section{Pink Shades}

BLANCEE FERRY SPENCER-Rose standard wings white, suffused with light pink......

CARMEITTA-The color is a lovely, delicate yet

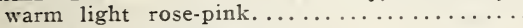

COUNTESS SPENCER - A lovely clear pink, shading deeper at edges.........................

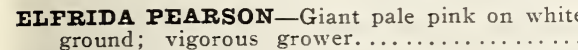
ground; vigorous grow rich rose pink, deeply flushed and shaded with salmon. A vigorous grower and exceptionally free flowering $\ldots \ldots \ldots \ldots \ldots \ldots \ldots \ldots \ldots$

HERCULES-Giant bright pink of excellent form

\section{Cream Pink Shades}

MARGARET ATIEE-Rich pink and salmon on

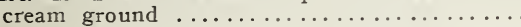

MARY PICKFORD-A beautiful, light and dainty cream-pink with a faint suffusion of salmon. A sturdy grower producing an abundance of four-flowered sprays on long stout stems...

MISS CAIIFORNIA-A distinct shade of salmon and cream-pink, with many four-flowered sprays; stems long and stout.............

MRS. ARNOLD IITCHCOCK - A charming shade of soft pink, flushed with salmon on a

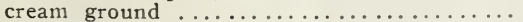

PICTURE - Giant flesh-pink, suffused creamy apricot; flowers are well waved and exquisite-

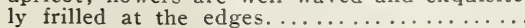

\section{Orange and Salmon Pink Shades}

BARBARA - Large bright salmon; should be

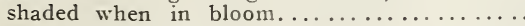

GEORGE SHAWYER-Giant salmon-rose.....

HEIEN IEWIS-Intense orange-crimson; wings

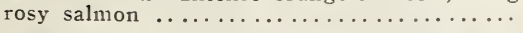

ILIUMINATOR - Rose, suffused with salmonorange; a grand variety of large size and grea substance; well waved.................

ROYAI SATUTE-Brilliant deep cerise, large and well-waved $\ldots \ldots \ldots \ldots \ldots \ldots \ldots \ldots \ldots$

TANGERINE - Deep glowing orange of great size; should be shaded when in bloom.......

\section{Rose Shades}

RENOWN-Large, clear carmine-rose.........

SUNSET-Bright rose on amber ground; quite
Per pkt. Per oz.

$\$ .10$

.10

.10

.10

.10

.10

.10

.10

.10

.10

.10

.10

.10

.10

.10

.10

.10

.40

.30

.30

.30

\section{Maroon and Purple Shades}

S.30

.30

.30

.40

.30

.30

.30

ROYAI PURPLE - Fine royal purple color flowers of large size; a distinct variety..... \$ $\$ .10$

SENATOR SPENCER - Chocolate, striped and mottled on ivory white................. .10

WARRIOR-Rich chocolate maroon flushed with bronze; great form and size............. .10

Per oz. Per pkt. $.10 \$ .30$ .30

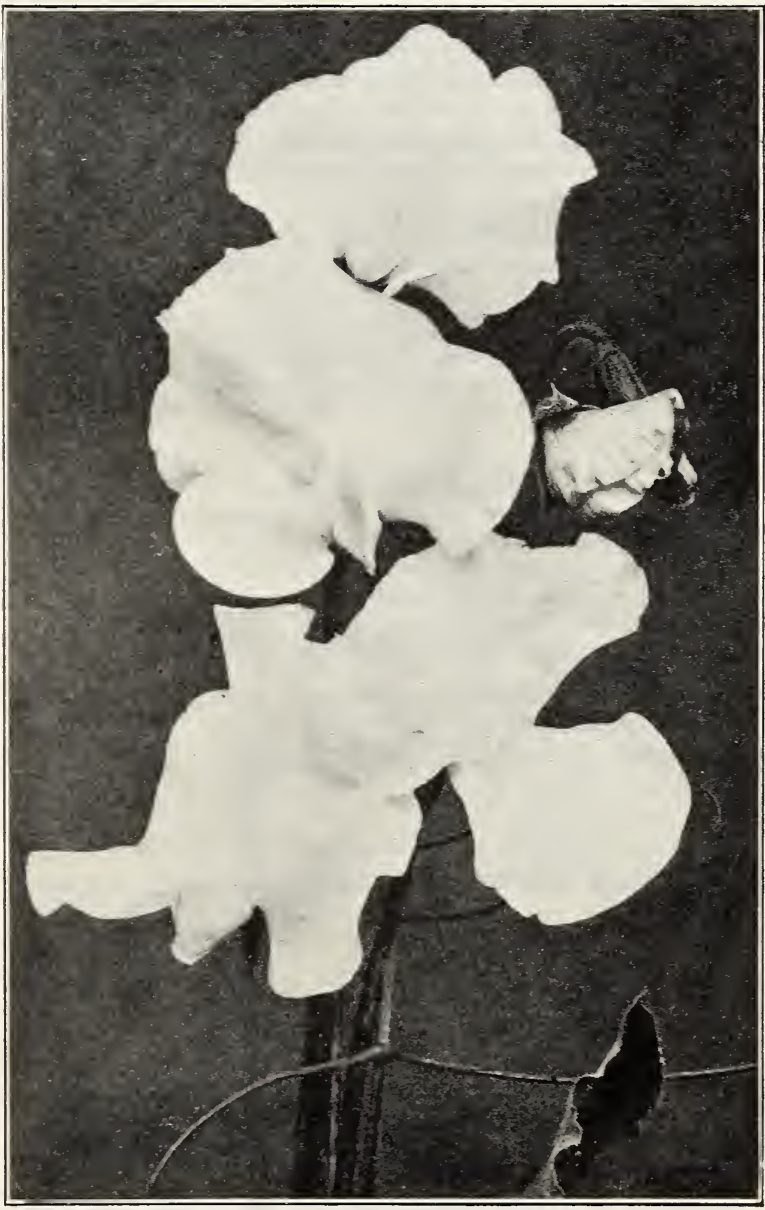




\section{Spencer Sweet Peas-Continued}

\section{Lavender and Blue Shades}

AUSTIN FREDERICK IMPROVED-Giant la-

vender, very fine.................. $\$ .10$

Per oz.

BLUE MONARCH-Dark blue

$\$ .30$

HEA VENLY BLUE-A fine new pure blue of a most beautiful tone of delphinium-blue. The flowers are of immense size with four invariably well placed on long stiff stems.........

MRS. TOM JONES-A fine blue sweet pea, color is a bright delphinium-blue, the flowers are
very large, beautifully waved and come four on a stem.

POWERSCOURT - Large lavender of exquisite

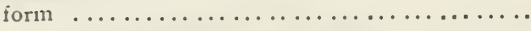

R. $\boldsymbol{\Sigma}$. FELTON - Pinkish lavender of immense size

.10 .30

WEMBLEY_Lavender suffused blue.

\section{White and Cream Shades}

CONSTANCE HINTON-Very large white, slight

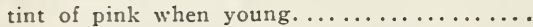

KING WHITE - A fine white sweet pea; the large flowers are borne almost invariably in fours on stout stems; the blossoms are finely frilled and are of great substance..........

MATCHLESS-The finest primrose variety; the blossoms are large and exquisitely frilled;

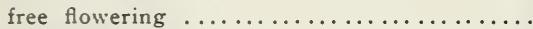

SNOWBALL - Glistening pure white; of large size and exquisite form and borne on long, stiff stems

YOUTH-Large pure white with margin of clear pink. Developed especially for its fragrance; undoubtedly the most fragrant Sweet Pea ever introduced

\section{Red Shades}

CRIMSON KING-Pure rich deep crimson; purer crimson and deeper tone than King Edward Spencer; the finest of all reds............

DEFIANCE-A fine large orange-scarlet, absolutely burnless, of vigorous robust habit.....

KING EDWARD SPENCER-Bright crimsonscarlet; magnificent in size and color...

ROYAL SCOT-A true brilliant scarlet; in size and form it surpasses any other of this shade and does not fade or burn in the hottest sunshine

*EARLY HARMONY_Clear lavender........

EARLY HEATHER BELL_Rich mauve.....

EARIY ROSE CHARM-Large bright rose...

EARLY ROSE DORE - Rose-pink suffused

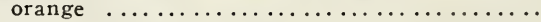

EARLY TRUE BLUE-A charming shade of blue

*EARIY SNOWSTORIM IMPROVED - Pure

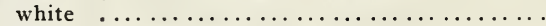

EARLY YARRAWA - Bright rose-pink with light wings $\ldots \ldots \ldots \ldots \ldots \ldots \ldots \ldots \ldots$.

*EARLY zVOLANER'S ROSE-Giant deep rose

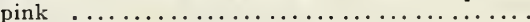

Collection of $\mathbf{5}$ sorts marked * for $50 \mathrm{c}$.

HALLAWELL'S CHOICE MIXTURE.

Per pkt.

.15

.15

.15

.15

.15

.15

.15

.15

.15

.15

.15

.15

.15

.10

Per oz. $\$ .60$ .60 .60 .60

HALLAWELL'S SPENCER MIXTURE-This mixture is a beautiful blend of the best varieties of Spencers in the proper proportion and includes all the latest novelties. Pkt., 10c.; oz., 25c.; I/4 lb., 75c.; lb., \$2.50.

SUBERB COLLECTION-Consisting of fifteen of the best varieties of Spencers of our selection, $\$ 1.00$.

(For varieties see back cover of catalogue)

SPECIAT COLIECTION-Consisting of seven of the best Spencer varieties of our selection, 50 c.

CUPID MIXED-Very dwarf and bushy, growing 1 foot high and spreading to about 2 feet in diameter; very effective when planted in a border. Mixture of all varieties. Pkt., 10c.; oz., 20c.; $1 / 4$ lb., 60c.; lb., $\$ 2.00$.

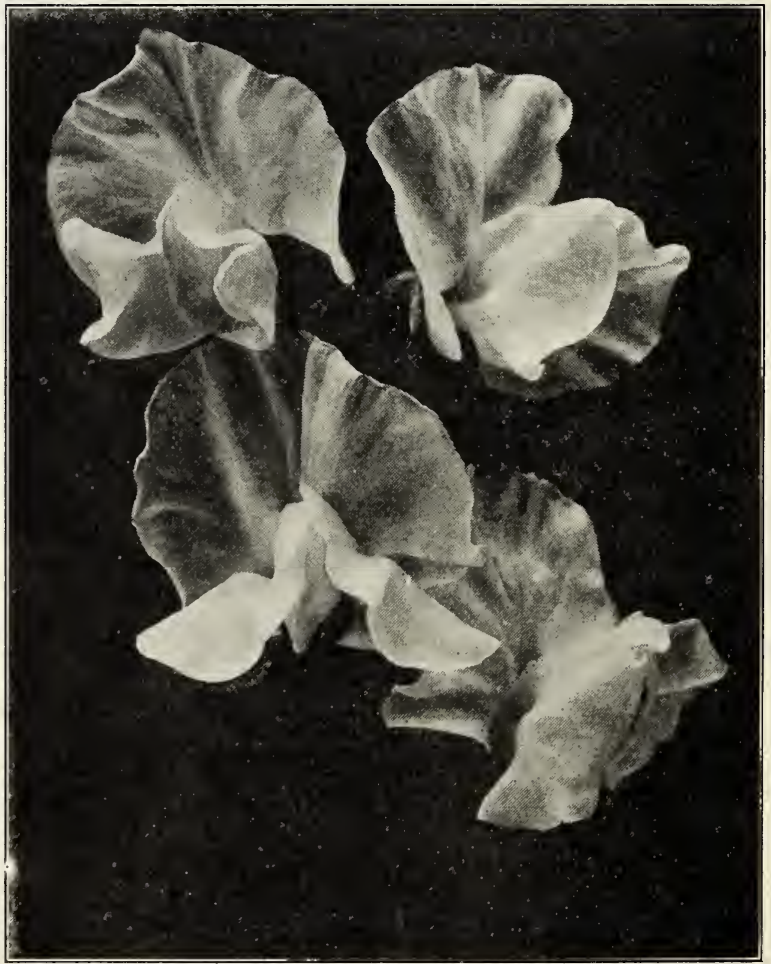

Winter Flowering Spencer Sweet Pea 


\section{Tagetes Signata Pumila}

A dwarf, compact, bushy annual Marigold with attractive fern-like leaves, densely covered with small orange flowers. Pkt., 10c.; $1 / 4$ oz., $40 \mathrm{c}$.

\section{Thalictrum Dipteriocarpum (Meadow Rue)}

This new introduction from China is a hardy perennial of vigorous growth, 4 to 5 feet high. The dainty rosy-purple flowers are brightened by a bunch of conspicuous yellow stamens and are produced in graceful sprays from July until September. Pkt., 25c. For plants, see page 85.

\section{Thunbergia or Black-Eyed Susan}

A tender annual climber, growing about 4 feet long and valuable for low fences or hanging baskets. Prefers a sunny situation. Blossoms are buff, orange or white, with dark centers. Mixed. Pkt., 10c.; I/4 0z., 40c.

\section{Tithonia Speciosa}

This native annual of Mexico is one of the most useful late Fall flowers we have, growing to a height of 8 to 10 feet, of free branching habit and is covered with bright orange flowers until cut down by extreme frost. As a cut flower this will be highly prized for decorative purposes. Seed should be sown in April or May and planted out when 8 inches high. Pkt., 15c.

\section{Torenia}

A half hardy annual, with trumpet-shaped flowers and growing 4 to 6 inches high; in bloom all Summer. Good for hanging baskets or borders, or for bedding. Sow in boxes from February to May.

FOURNIERI-Velvety blue, with three dark spots of indigo and a bright yellow throat. Pkt., 15c.

WHITE WINGS-Dainty white flowers, tinted with rose at throat. Pkt., 15c.

\section{Trachelium Coeruleum}

A free flowering perennial producing large cloud-like heads of pale mauve flowers, resembling the Gypsophila; $1 \frac{1}{2}$ feet high. Pkt., $15 \mathrm{c}$.

\section{Valerian}

Showy plants for mixed borders or shrubberies, bearing large corymbs of bright flowers; bears shade and moisture well. Hardy perennial $2 \frac{1}{2}$ feet. Flowers bright red and white. Crimson, White, Rose or Mixed. Pkt., $10 \mathrm{c}$.

\section{Verbascum Olympicum}

A stately, hardy perennial plant attaining a height of 6 feet. The large leaves are covered with silvery down, above which rises a pyramid of bright yellow flowers. Pkt., 10c.

\section{Verbena}

One of the most popular half-hardy perennial plants for Summer bedding, producing. freely their brilliant flowers of almost every color. Sown early in a hotbed, they commence to bloom in June and continue until frost. Plants from seed will grow and bloom better than those from euttings.

MAMMOTH MIXED-Saved from the choicest large flowering varieties and contains all the newest and most striking colors. Pkt., 10c.; $1 / 4$ oz., $50 \mathrm{c}$.

The following separate colors can be supplied at $10 \mathrm{c}$. per pkt., each, or $1 / 4$ oz., 60 c.; White, Scarlet, Purple with white eye; Pink.

GIANT BLUE-Blue with white eye. Pkt., 15c.

ROSEA STELLATA-Rose-pink with white eye; large size. Pkt., $15 \mathrm{c}$.

IUCIFER-A new variety of large size; color an intense deep cardinal-scarlet throughout. Pkt., 15c.

IUMINOSA-Luminous flame-pink shading to salmon; large and very fine. Pkt., 15c.

HALIAWELI'S GIANT MIXED-A wonderful mixture of extra large flowering varieties with conspicuous white eyes. Pkt., 15c.; $1 / 4$ oz., $75 c$.

\section{Veronica (Speedwell)}

A hardy perennial producing long spikes of brilliant blue flowers, excellent for growing in shady places and requiring plenty of moisture.

LONGIFOLIA-Handsome heads of rich violet blue; 2 feet high. Pkt., 10c.

\section{Vinca (Madagascar Periwinkle)}

Ornamental, free-blooming, tender perennial, useful for bedding in Summer and for the greenhouse in Winter. Seed should be sown early to bloom the first year. The trailing Blue Myrtle or Vinca does not seed.

PURE WHITE-Pkt., 10c.

WhITE, Crimson eye-Pkt., 10c.

ROSE-Pkt., $10 \mathrm{c}$.

MIXED-Pkt., 10c.

VIOLAS or TUFTED PANSIES-See page 44.

\section{Virginia Stocks}

A hardy annual, growing about 9 inches high and blooming profusely. Of easy culture, and can be had in continuous bloom by sowing the seed at frequent intervals during Spring and Summer.

MIXED COLORS-Pkt., 10c.; $1 / 2$ oz., 25c.; oz., 40c.

ROSE-Bright rose. Pkt., 10c.; oz., 50c.

\section{Viscaria}

A free blooming annual growing one foot tall and covered during Summer and Fall with flowers similar in shape to a single pink. Sow the seed in the open in Spring and thin out when well started to prevent over-crowding.

CARDINAIIS-Brilliant crimson. Pkt., 10c.; $1 / 4$ oz;, $25 \mathrm{c}$.

OCULATA AZUREA-Delicate blue with dark eye. Pkt., 10c.

\section{Wallflower}

Half-hardy perennial blooming the first year from seed. Grows 1 to 2 feet high and bears long stems of fragrant flowers. It is best to renew the plants every 2 or 3 years by resowing the seed. An old-fashioned flower, which is always popular. Sow the seed in boxes in the Fall or early in the year. For extra early bloom next season, sow in May or June.

SINGLE BLOOD RED-Pkt., 10c.; $1 / 4$ oz., 30c.

SINGIE GOIDEN RING-Pkt., 10c.; $1 / 4$ oz., $30 \mathrm{c}$.

SINGLE GOLIATH_Flowers of a rich shining red, with a black velvety sheen. A splendid variety. Pkt., 10c.; $1 / 4$ oz., $30 \mathrm{c}$.

SINGLE VESUVIUS - New buds orange-scarlet, expanding to bronzy-yellow; very showy. Pkt., 10c.; I/4 oz., 30c.

SINGLE EXTRA FINE-Mixed, all colors. Pkt., 10c.; $1 / 4$ oz., 25c. DOUBLE FINEST MIXED-Splendid branching varieties. Pkt., $15 \mathrm{c} . ; 1 / 8$ oz., $50 \mathrm{c}$.

PARISIAN_A single flowering type, which may be treated as an annual, flowering the first year from seed.

PARISIAN BLOOD RED-Pkt., 10c.; $1 / 4$ oz., $25 \mathrm{c}$.

PARISIAN YELLOW-Pkt., 10c.; $1 / 4$ oz., $25 \mathrm{c}$.

PARISIAN MIXED-Pkt., 10c.; $1 / 4$ oz., $25 \mathrm{c}$.

\section{Wild Flowers of California}

\section{BARTONIA AUREA \\ CLARKIA ELEGANS \\ COLLINSIA}

ESCHSCHOLTZIA CALIFORNICA

GIIIA CAPITATA

GODETIA AMTOENA

LEPTOSYNE MARITIMA

LUPIN NANUS

NEMOPHILA INSIGNIS

PHACELIA CAMPANULARIA

Collection of one pkt. each of the above 10 best hardy sorts for $85 \mathrm{c}$.

Mixture of wild and hardy cultivated flower seeds. Pkt., 10c.; oz., 35c.; $1 / 4$ 1b., \$1.00; 1b., \$3.50. 


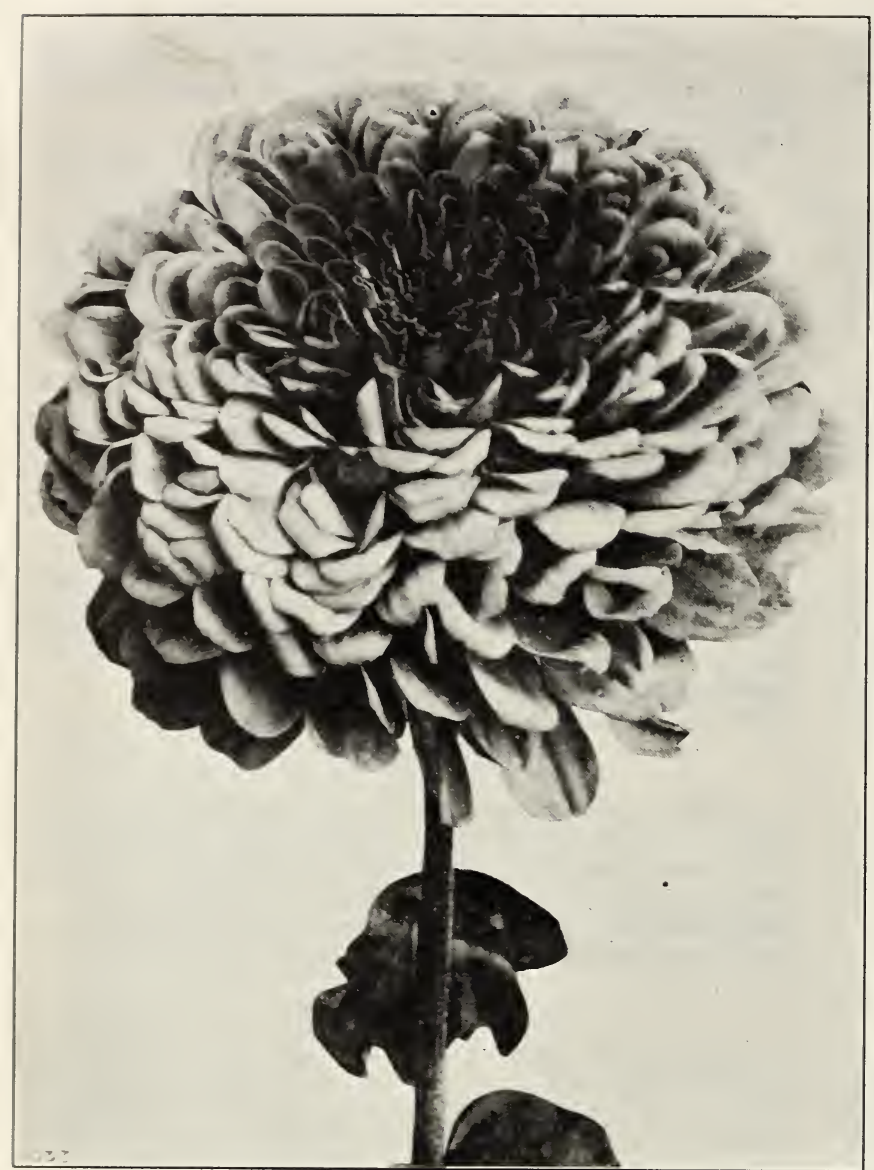

Zinnia Dahlia Flowered

\section{New Giant}

\section{Dahlia Flowered Zinnias}

The plants of this new race are strong and of vigorous habit, fully three feet high, producing many flowers with stout stems, in a wide range of colors. The flowers in full bloom often measure four inches in depth and six to eight inches in diameter, closely resembling show dahlias.

BUTTERCUP_An immense deep canary yellow. Pkt., 20c.

CRIMSON MONARCH-By far the largest and best of the red shades. Flowers often eight inches in diameter. Pkt., 20c. DREAM-A fine lavender turning to purple. Pkt., 20c.

EXQUISITE-Light rose with a deep rose center. A most pleasing color. Pkt., 20c.

GOLDEN STATE_A very rich orange-yellow. Yellow in the bud turning to an attractive orange when in full bloom. Pkt., 20c.

LEMON BEAUTY_Immense flowers of a golden yellow or brown, decidedly a pastel shade. Pkt., 20c.

OLD ROSE_A real Old Rose shade. Pkt., 20c.

ORIOLE-Immense flowers of orange and gold. Pkt., 20c.

SCARLET FLAME-Bright scarlet with a blending of orange throughout the petals. Pkt., 20c.

Collection of 6 packets of any of the above varieties for $\$ 1.00$. HAIIA WELI'S SPECIAL MIXTURE-A well blended mixture containing all the very best sorts. Pkt., $15 \mathrm{c}$.; $1 / 4$ oz., $60 \mathrm{c}$.

\section{Zinnias (Youth and Old Age)}

The Zinnia is one of the most brilliant and showy of annuals, and has long been a general farorite. They come into flower early in the Summer and keep on blooming until hard frost; half-hardy. Sow the seed early in a hotbed and transplant. Seed may be sown until June for very late blooming.

IMPROVED DOUBLE IARGE FLOWERING DWARF -Very desirable for general use, forming bushy compact plants about 2 feet high.

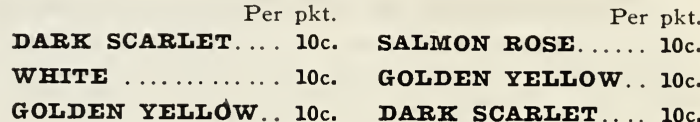

-Any of the above colors, $1 / 4$ oz., 35 c.

Collection of the above 6 sorts, 50c.

IMPROVED DWARF DOUBLE MIXED-Pkt., 10c.; I/4 Oz., 25c.; oz., 75c.

GRANDIFLORA ROBUSTA-A very fine mammoth type The blossoms are globe-shaped, very large and in numerous colors. The plants are of robust habit, attaining a height of about 3 feet.

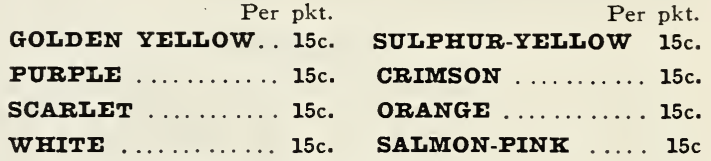

-Any of the above colors, $1 / 4$ oz., $50 \mathrm{c}$.

Collection of 6 packets of any of the above sorts for 75c.

GRANDIFLORA ROBUSTA MIXED-Pkt., 10c.; $1 / 4 \mathrm{oz}$. $35 \mathrm{c}$.; oz., $\$ 1.00$.

RED RIDING HOOD-Of compact form and covered the entire Summer with little button-like intense scarlet flowers 1 inch across; 1 foot tall; fine as a border plant. Pkt., 10c.; $1 / 4$ oz., 30c.

DOUBLE CRESTED or CURIED-The petals are twisted and curved into most graceful forms. Mixed. Pkt., 10c.; 1/4 oz., 40c.

\section{Zinnia-Giant Picotee Mixed}

A remarkable class containing many colors, each petal being distinctly tipped, giving the flowers a very attractive and pleasing appearance. Pkt., $15 \mathrm{c}$.; $1 / 4$ oz., $50 \mathrm{c}$.

\section{Xeranthemum}

A bright and pretty "Everlasting" with silvery foliage and silky flowers in rose, white and purple, which are not only showy in the garden but very useful as dried flowers in Winter bouquets. Grows 2 to 3 feet high, can be sown in the open in Spring. Pkt., 10c.; $1 / 4$ oz., 30c.

\section{Ornamental Grasses}

AGROSTIS NEBUIOSA-A graceful annual border grass. Pkt., $10 \mathrm{c}$.

BRIZA MAXIMA (Quaking Grass)-Pkt., 10c.

BROMUS BRIZAFFORMIS-Elegant Briza-like grass. Pkt., 10c. COIX IACRYMA (Job's Tears)-Grows 2 feet high. Pkt., 10c. ERAGROSTIS ELEGANS (Love Grass)-Annual, 1 foot. Pkt., 10c.

EULALIA JAPONICA ZEBRINA-5 feet. Pkt., 10c.

IAGURUS OVATUS (Hare's Tail Grass)-Pkt., 10c.

PENNISETUM RUPPELIANUM (Purple Fountain Grass)Graceful green foliage and purplish plumes; 3 feet. Pkt., 10c. ZEA JAPONICA FOLIUS VARIEGATA (Striped Maize) -Pkt., 10c. 


\section{Our Nursery Department}

Customers will please remember that when our busy season commences we are rushed with orders and it may be a few days before their orders receive attention; but they may rest assured that there will be no unnecessary delay in shipping.

GUARANTEE-We will warrant all trees and plants to be good and thrifty, but having no control over them after delivery to the transportation companies, or over the planting and care after they are received by the buyer, we will not be responsible in any other direction than as stated. We exercise great care to have all our nursery stock true to name. Nevertheless it is understood that should any stock prove otherwise, we shall not be liable for any sum greater than that paid us for only such stock as shall prove untrue.

PRICES quoted are f. o. b. San Francisco except where noted. Where express office differs from postoffice be sure so to state.

CLAIMS-Should any errors occur we desire to be informed upon receipt of goods, in order that we may rectify them without delay. All claims must be filed within ten days after the arrival of the shipments.

\section{THE ROSE}

December, January, February and March are the best months for planting but should the season be favorable you can still plant during the early part of April. The plants sent out during these months are what we call dormant two-yearold budded plants. Roses give best results when planted in a fairly sunny location and in good heavy sediment soil to which may be added some old nianure or bone meal, but never use fresh manure. When planting straighten out all roots and as the dirt is filled in see that it is well packed around them; this keeps out the air and encourages a new growth of rootlets. Be sure that the Rose is planted so that the point where it is budded shall be just below the surface.

\section{Pruning}

This should be done during the months of December, January and February; at that time the bushes are in a dormant condition. Cut just above a prominent but dormant bud that is pointing outward.

The Tea Varieties (T.) require to be more severely pruned than any other sort. Cut back to about 6 or 7 inches from the old wood each year; keep the center of the plant open and thin out all the weak wood, leaving about 5 or 6 shoots, according to the size of the plant.

Hybrid Teas (H. T.) should have almost as much pruning done as the Teas.

Hybrid Perpetuals (H. P.). First cut out any dead or weak wood, keeping the center of the plant open, then cut the remaining shoots down to sound, healthy wood to within 6 or 12 inches of the base; this hard pruning keeps the plants compact and promotes new life for future years. After the first year they require little pruning except to cut out dead wood.

Austrian and Hybrid Briars (H. B.) require to be cut back fairly hard when planted out but afterwards need no pruning except to cut out dead wood.

Polyantha or Baby Roses (P.) should be but little pruned; merely cut out dead wood and keep the center of the plant from getting too crowded.

Single (S.) require little (if any) pruning when established, but will be the better for being cut back when planted.

Climbers. These are not usually pruned as their duties are to cover certain objects. They should, however, be periodically thimned out.

\section{Standard Roses}

The following varieties can be supplied in tree-shaped form on stout stems $31 / 2$ to 4 feet high, $\$ 2.00$ each:

CAROLINE TESTOUT-Pink, very full and large. CHEERFUL_Flaming orange in bud, turning to pink. COLUMBIA-Rose-pink, delightfully fragrant. CONSTANCE-Orange-yellow turning to golden yellow. FRAU KARL DRUSCHKI-Snow-white; very large. GENERAL MAC ARTHUR_Bright scarlet-red. GOLDEN EMBLEM-Large, rich, deep golden yellow. GOLDEN OPHELIA-Golden yellow.

GORGEOUS-Varies from orange to rose-pink.

HADLEY-Dark crimson, sweet scented.

HOOSIER BEAUTY-Rich velvety crimson.

INDEPENDENCE DAY_Bright apricot-yellow.

IRISH ELEGANCE--Single apricot and bronze.

IRISH FIREFLAME-Single orange flushed crimson.

LADY HILLINGDON-Deep apricot-yellow.
LADY PIRRIE-Deep coppery salmon.

LOS ANGELES-Brilliant flame-pink.

MME. BUTTERFLY_Pink suffused apricot and gold.

MME. EDOUARD HERRIOT, the Daily Mail Rose-Coralred shaded yellow at base, buds are long and pointed.

MME. MELANIE SOUPERT-Gold and amber.

MRS. CHARLES RUSSELL-Brilliant rosy carmine.

OPHELIA-Salmon-flesh shaded with rose, fragrant.

PADRE-Coppery scarlet flushed with yellow at base.

PAPA GONTIER - Rosy crimson turning to pink.

QUEEN ALEXANDRA-Intense vermilion, deeply shaded old gold on reverse of petals.

REV. F. PAGE ROBERTS-Orange gold shaded to saffronyellow.

SOUVENIR DE CLAUDIUS PERNET-Sunflower-yellow. 


\section{Best Roses of Recent Introduction}

Any of the following, except where noted, in strong 2 -year-old plants. $\$ 1.00$ each; $\$ 9.00$ per 10 ; prepaid within 3rd zone.

ANGELE PERNET (H. T.) Buds of deep flaming orange, opening to seni-double blooms of brilliant tango. A good grower and remarkably free from mildew. $\$ 1.50$ each.

BETTY UPRICHARD (H. T.)-The inner face of petals is a delicate salmon-pink to carmine, while the outer petals are a glowing carmine with a suffusion of orange; a glorious combination of colors. Awarded Gold Medal.

CUBA (H. T.) - Although the flowers are almost single they possess a charm and brilliancy which is an entirely new tone in Roses, a bright vermilion-scarlet overlying an orange ground. A vigorous grower and good bloomer. $\$ 1.50$ each.

DAME EDITH HELEN (H. T.)-A new glowing pink variety which holds its color with age. The flowers are large and full, of perfect form, carried on rigid, erect stems. Vigorous grower, free flowering and sweet scented. $\$ 1.50$ each.

DIADEM (H. T.)-A large, fragrant double flower of coppery-orange, with salmon and flame tints.

ELDORADO (H. T.) - A clear yellow rose that holds its color when fully opened. The flowers are very double with petals beautifully crinkled at the center of the bloon. A fine garden rose.

INDEPENDENCE DAY (H. T.)-Flame tints overlying a bright apricot color, blooms carried on erect stems, exceedingly free flowering.

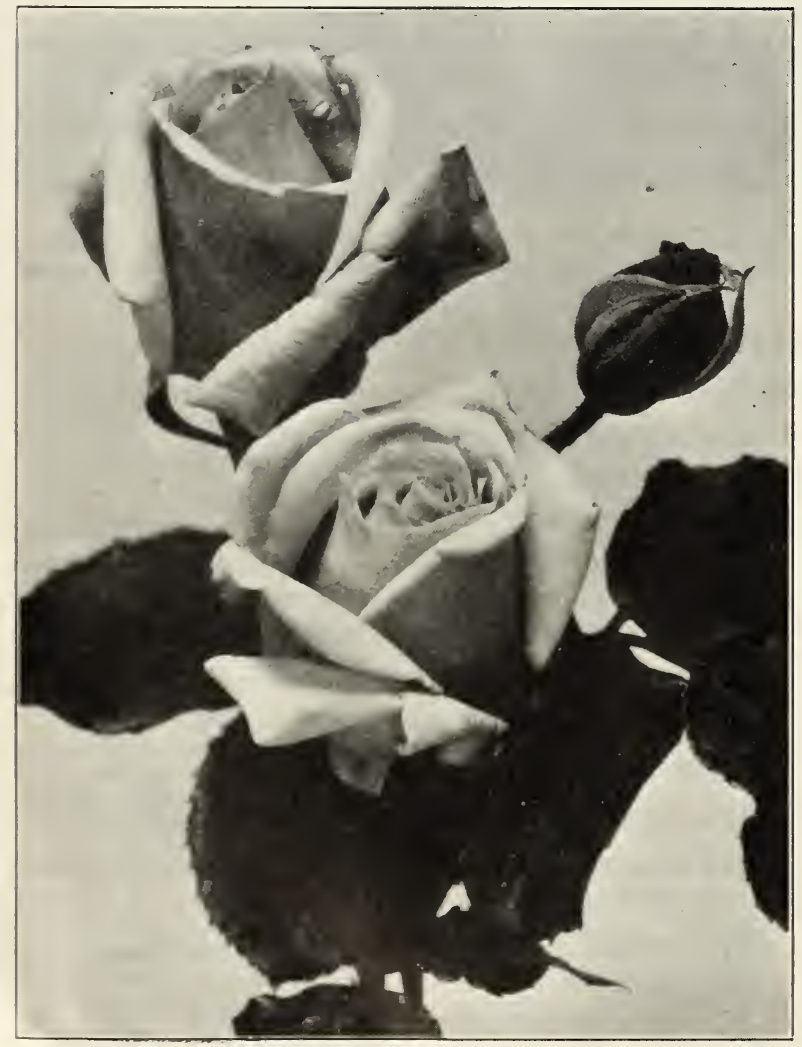

Rev. F. Page Roberts

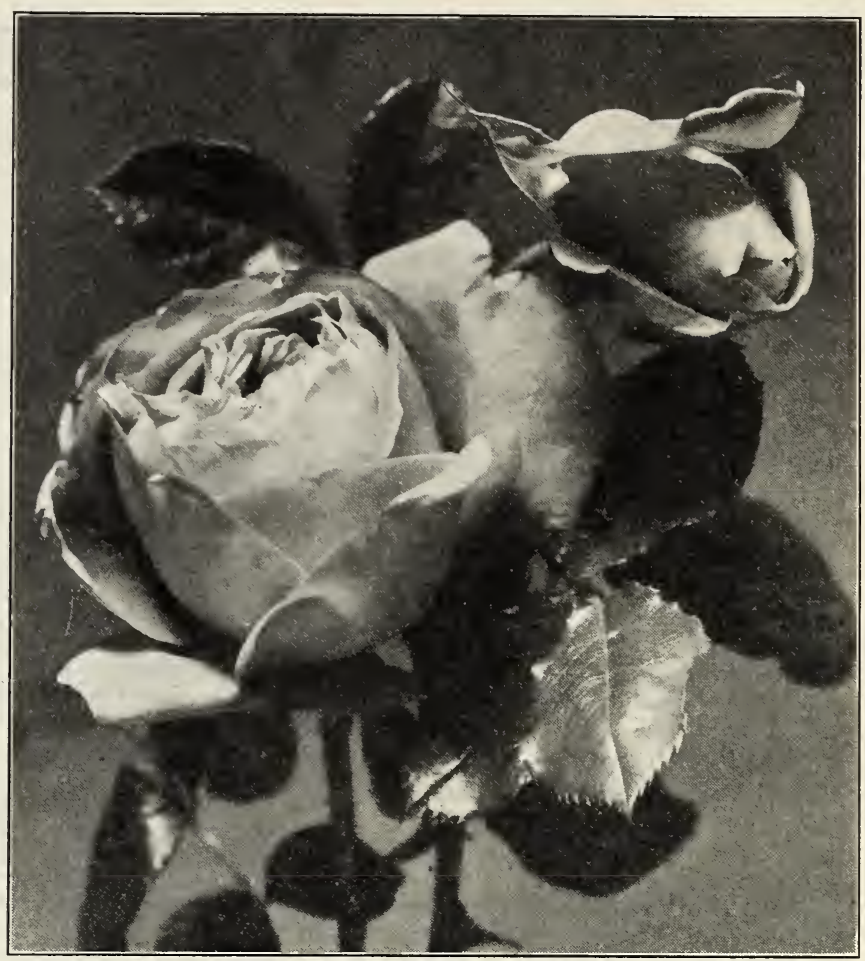

Queen Alexandra

LADY MARGARET STEWART (H. T.)-The flowers in the young stage are deep sunflower-yellow heavily veined and splashed with orange-scarlet. The fully developed flowers are cadmium-orange. Buds long and pointed opening to very full flowers. Vigorous grower and free from mildew. A new Gold Medal Rose. $\$ 1.50$ each.

MARY PICKFORD ( $\mathrm{H}$. T.)-An exquisite shade of orangeyellow stained on the reverse of the outer petals with salmon and salmon-blush. The buds are long and pointed and expand to blooms of moderate size. Free bloomer.

MRS. ERSKINE PEMBROKE THOM (H. T.)-Color is a distinct, clear, deep, canary-yellow. The buds are of good long shape and develop into good-sized full flowers.

MRS. LOVELL SWISHER (H. T.) - Long shaped, deep coppery-salmon buds opening to good-sized double, salmon-pink blooms. Vigorous grower and free bloomer.

PRESIDENT CHERIOUX (H. T.) - Very large, salmonpink blooms with reddish buff shadings and petals of waxy texture. Splendid grower and liberal bloomer.

QUEEN ALEXANDRA (H. T.)-Color intense vermilion, deeply shaded old gold on reverse of petals; a remarkable and pleasing color combination, which is quite pronounced during cool weather; in hot weather the colors are dulled. A warded Gold Medal.

REV. F. PAGE ROBERTS (H. T.) -A most beautifully shaped long bud and a full double flower of a rich. orange-gold, shaded to saffron-yellow; a vigorous grower and free bloomer. Awarded Gold Medal.

SHOT SILK (H. T.)-Its brilliant color is hard to describe; sort of an orange-cerise suffused with gold. Buds and flowers of medium size, fragrant and produced freely.

SOUVENIR DE GEORGES PERNET (H. T.)-Brick-red buds, opening to terra-cotta-pink blooms of immense size, very double and fragrant. Stocky plant of free blooming habit. Like all Pernets should be pruned lightly. 


\section{Roses of Special Merit}

Strong 2-year old plants, $75 \mathrm{c}$ each; $\$ 7.50$ per dozen; prepaid within third zone, when in dormant condition. All the Roses we offer are selected stock that will bloom freely the first season with the exception of some of the climbers.

AUSTRIAN COPPER (H. B.)-Rich coppery-red on inside of petals, yellow on outside; single.

CHEERFUL (H. T.)-Flowers large and full, of good shape. Flaming orange in bud turning to pink when fully developed. Growth vigorous and exceptionally free flowering; color unique.

CONSTANCE (H. T.)-Lovely, long orange-yellow buds, sometimes streaked crimson. Flowers golden yellow, full and globular, free flowering.

GOLDEN EMBLEM (H. T.)-A superb new rose, flowers are large and of perfect shape. In color it is a rich deep golden yellow, tinged with coppery orange. It is a perpetual bloomer, of free and branching habit with glossy green foliage. Awarded Gold Medal.

GOLDEN OPHELIA (H. T.) - The flower is of medium size, golden rellow in the center, paling slightly toward the outer petals; of perfect form.

GORGEOUS (H. T.)-Orange-yellow, with reddish copper shadings. It varies from orange to rose-pink. The flowers are large, full and well formed.

HOOSIER BEAUTY (H. T.)-One of the grandest red roses of an extremely rich velvety crimson color which does not shade into maroon. A heary bloomer of strong. upright growth.

IRISH ELEGANCE-A single rose, beautiful in bud; color, apricot shading to bronze at base of petals.

IRISH FIREFLAME-A beautiful single rose, bearing its flowers in clusters of five or more; buds are a rich deep orange flushed with crimson, opening to a large single flower of an old gold color. Awarded Gold Medal.

ISOBEL_A fine new single rose, carmine-red, flushed orange-scarlet, large petals, very free flowering.

K. of K. (H. T.) - Intensest scarlet known. Semi-single with huge petals. Free and continuous bloomer. Sweet scented. A warded Gold Medal.

LADY PIRRIE (H. T.)-Deep coppery salmon, inside of petals apricot-yellow flushed copper. Beautiful in bud form; semi-double when open; good grower and free bloomer.

LOUISE CATHERINE BRESLAU (H. T.) - The buds are coral-red shaded with chrome-yellow, while the expanded flowers, which are very large, are shrimp-pink shaded coppery-orange and chrome yellow.

LYON (H. T.)-Flowers large and double, of good substance, shrimp pink, edges coral-red or salmon-pink shaded chrome-yellow.

MADAME MELANIE SOUPERT (H. T.)-The best bedding rose in its color. Its tints are gold and amber, copper and yellow. It has a long bud on a strong stalk and a large, well shaped bloom.

MISS LOLITA ARMOUR (H. T.)-The flowers are large and full with petals of great substance and sweetly scented; as the flowers expand they develop to a deep coral red with a golden coppery red suffusion. A rigorous grower and free bloomer.

MRS. HENRY MORSE (H. T.) -A bright flower of two contrasting tones of pink with an underlying yellow glow; flowers double, high centered and large. Plants tall and branching, very free bloomer.

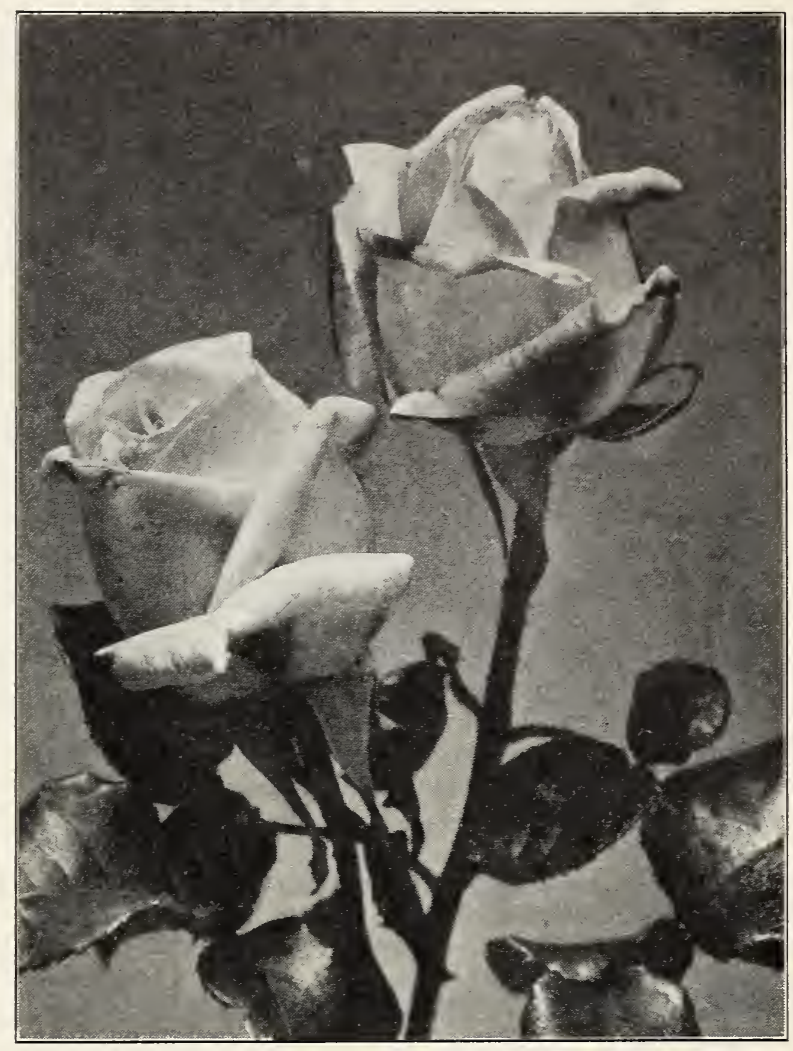

Golden Emblem

MRS HERBERT STEVENS (T.)-A large pure white rose perfect form with high pointed center.

MRS. S. K. RINDGE (H. T.)-Clear, rich chrome-yellow becoming suffused with soft pink with age instead of fading. Buds are long and pointed and carried on stiff stems. Flowers moderately double and produced freely.

MRS. W. CHRISTIE MILLER (H. T.)-Blooms of enormous size, quite full, petals of great substance. Rosy carmine, inside of petals soft pearly blush.

PADRE (H. T.) - A most novel and attractive coloring, with fine long petals of coppery scarlet flushed with yellow at the base; an exceedingly free flowering sort of strong upright growth.

RED RADIANCE (H. T.)-Clear cerise-red, large, full and well formed; a fine garden variety.

ROSE MARIE (H. T.) - Beautiful long buds and well formed flowers of a clear rose-pink; very fragrant.

SOUVENIR DE CLAUDIUS PERNET (H. T.) - Color sunflower-yellow, deeper in the center, very free and continuous bloomer, flowers very large and full, carried erect.

SUNBURST (H. T.)-Yellow suffused orange at center, buds long and flowers large and fairly double.

SUNSTAR (H. T.)-An attractive novelty of variable coloring, usually lemon-yellow, every petal edged, veined and splashed with rose and vermilion. Flowers are not very full but the buds are long and elegant and carried on rigid stems.

WM. F. DREER (H. T.)-Soft silvery shell-pink suffused orange and golden-yellow at base. 


\section{Roses-Choice Assortment}

Strong 2-year old plants, 50c each; $\$ 5.50$ per dozen. Prepaid within third zone, when in dormant condition.

AMERICAN BEAUTY (H. P.)-Deep pink shaded toward the center with carmine-crimson. Large, full and fragraut.

BETTY (H. T.)-Coppery-rose overspread with golden-yellow; flowers large, fairly double, fine form; buds very long; deliciously perfumed.

BLACK PRINCE (H. P.)-Dark crinson, nearly black. medium size.

CAROLINE TESTOUT (H. T.) -A splendid rose of a beautiful pink color and very full and large, blooming continuously throughout the season.

CECILE BRUNER (P)-The well known "Baby Rose." Flowers come in clusters and bloom for a long period; color, beautiful salmon-pink, shading deeper toward center.

COLUMBIA (H. T.)-This beautiful rose is of strong, vigorous habit of growth and exceptionally free flowering. The flowers, which are of good size, are perfect in form. In color it is a most pleasing shade of rose-pink, and delightfully fragrant.

DUCHESSE DE BRABANT (T.)-A very fragrant rose; bright silvery pink, always in bloom.

EDWARD MAWLEY (H. T.) - Rich velvety crimson, blossoms large and full, and petals of great substance.

FRAU KARL DRUSCHKI (H. P.)-Also known as the White American Beauty. Pure snow-white; very long buds; shell-shaped petals, opening to very large flowers.

GENERAL JACQUEMINOT (H. P.) - Bright velvety crimson, shapely buds and handsome blooms. Very fragrant.

GENERAL MacARTHUR (H. T.) - Bright scarlet-red, large and full; buds of an ideal shape, carried on strong stalks; heavily perfumed; vigorous grower and free bloomer.

HADLEY (H. T.)-Excellent dark crimson variety of good shape, size and substance, sweet scented; growth free and constant.

JULIET (H. B.) -A distinct variety with large, full flowers. The outside petals are old gold and the interior rosy red. changing to deep rose; fragrant.

KATE MOULTON (T.)-Clear pink; the petals, which are recurved, are tipped white; the buds are long and pointed.

LA FRANCE (H. T.)-Bright satin pink and rose, with reflexed petals which are silvery pink; very large and double.

LADY HILLINGDON (T.)-The flowers are deep apricot yellow, beatiful in bud or when full blown, with petals of great substance. A strong, vigorons grower and a very free bloomer.

LOS ANGELES (H. T.) - A very vigorous grower and contimuous bloomer. producing long stemmed fragrant flowers of a brilliant flame-pink shading to coral and gold at the base of the petals; buds long and pointed.

MADAME ABEL CHATENAY (H. T.)-Strong grower, producing very freely, flowers of carmine-rose shaded salmon.

MME. BUTTERFLY (H. T.)-A new and splendid sport of Ophelia with all its good characteristies. Flowers are a brilliant pink suffused apricot and gold.

MME. EDOUARD HERRIOT, the DAILY MAIL ROSE (H. T.) - The buds, which are long and pointed, are coral-red shaded yellow at base; the open flowers of medium size and semi-double are a beautiful coral-red shaded with yellow and bright rosy scarlet. $\mathrm{A}$ vigorous grower.

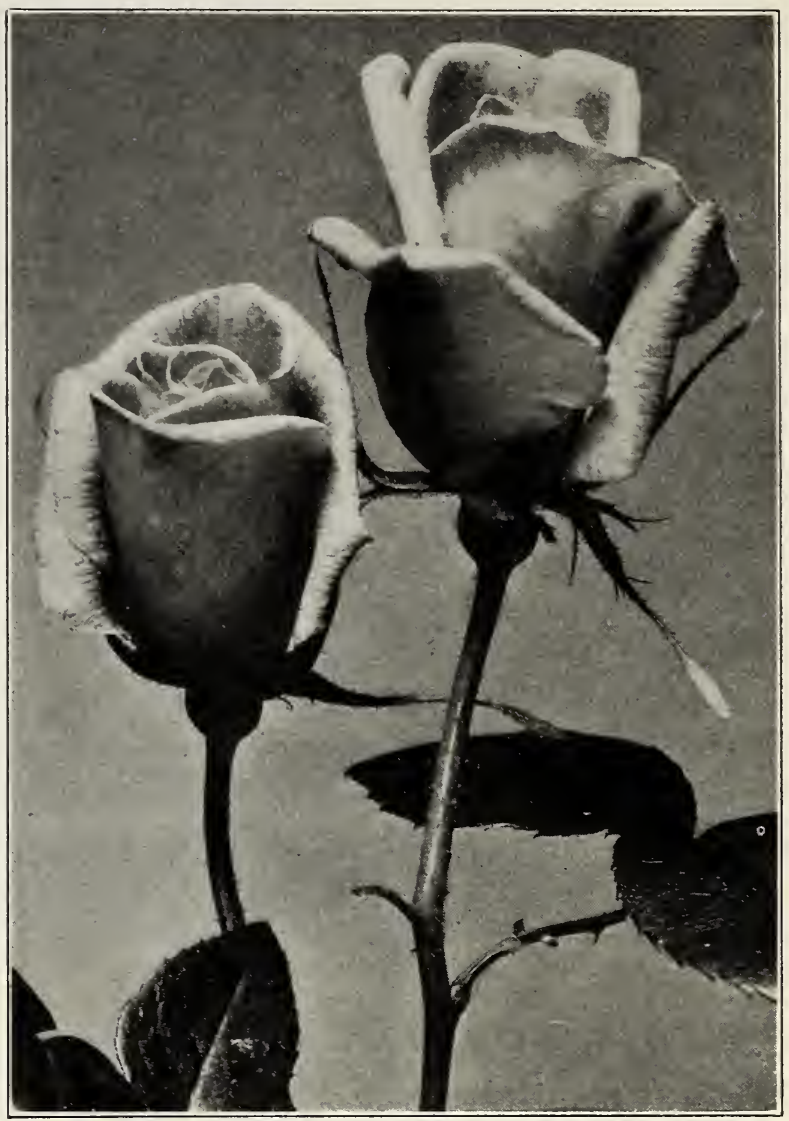

Mme. Edouard Herriot or Daily Mail

MAMAN COCHET (T.)—Clear rich pink, rigorous grower and free bloomer.

MRS. AARON WARD (H. T.) - Distinct Indian-yellow shading lighter toward the edges. Very free flowering.

MRS. CHARLES RUSSELL (H. T.)-Brilliant rosy-carmine with scarlet center; flowers beautifully formed and borne on strong stems.

OPHELIA (H. T.)-Flowers salmon-flesh shaded with rose, large good shape, standing up well on stiff stems; fragraut and very free flowering, free from mildew.

PAPA GONTIER (T.) - Rosy crimson with carmine center shading to pink as it opens. Moderately double but beautiful in bud form; one of the freest blooming roses known.

PAUL NEYRON (H. P.)-Deep rose color, enormous flowers; very fragrant.

PERLE D'Or (P.) - Salmon tinted pink, flowers come in cluster, a salmon "Baby Rose."

PREMIER (H. T.) - Flowers pure rose-pink, deliciously fragrant and borne on stiff thornless stems; strong grower and free bloomer.

RADIANCE (H. T.)-Brilliant rose pink; large and full flowers of beautiful form. Very prolific.

RAINBOW IMPROVED (T.) - Deep pink, penciled and mottled with glowing crimson; base of petals a bright amber color; fine buds; large flowers. Prune sparingly.

ULRICH BRUNER (H. P.) - Bright cherry-red, large fine form; a strong hardy grower; highly perfumed. 


\section{Climbing Roses of Special Merit}

Strong 2-year old plants, $75 \mathrm{c}$ each; $\$ 7.50$ per dozen; prepaid within third zone, when in dormant condition.

AMERICAN PILIAAR - A climber of vigorous habit. The single flowers often measure 3 inches across and are borne in large clusters; color is pretty shade of rosepink, foliage large glossy deep green.

BELLE OF PORTUGAL-A vigorous climber, flowers are a soft salmon-pink of large size; does not commence blooming until the second season.

CLIMBING HOOSIER BEAUTY (H. T.)-Of strong vigorous habit, bearing beautiful long buds of an intense rich, dazzling crimson-scarlet.

CLIMBING IRISH FIREFLAME (H. T.) - A vigorous climbing type of the beautiful single rose, producing in profusion throughout the summer sprays of brightcolored flowers tinted orange crimson and gold.

CLIMBING LADY HILLINGDON (T.)-Apricot-yellow: a climbing sport of the bush variety.

CLIMBING LOS ANGELES (H. T.) - Same as the bush variety except in habit.

CLIMBING MME. EDOUARD HERRIOT (H. T.) - A very vigorous climbing sort of this great favorite. Flowers same as in the bush variety. It is easy to predict the greatest popularity for this extremely valuable novelty.

CLIMBING MRS. AARON WARD (H. T.) -A vigorous and remarkably free flowering climber; color, Indianyellow shading lighter towards the edges.

CLIMBING PAPA GONTIER (T.) - Splendid, long pointed buds which are deep rosy red. It is a free and continuous bloomer and rapid grower.

CLIMBING SOUVENIR DE WOOTTON (H. T.) - A strong grower producing in great profusion large deep red flowers; a constant bloomer.

CLIMBING YELLOW CECILE BRUNER (P.) - About the same as the popular Climbing Cecile Bruner but with flowers of a pleasing yellow shade. Extremely vigorous.

GLORIE DE DIJON (T.)-Buff with orange center, very large and full. A good climber and free bloomer.

MADAME ALFRED CARRIERE (N)-A vigorous grow. ing climber, very fine in buds; color creamy white, shaded yellow at center.

MARECHAL NIEL (N.)-A beautifully deep yellow rose; large globular, sweet scented; a good pillar rose.

TAUSENDSCHOEN-A fast-climbing rambler; the semidouble soft pink flowers are 3 inches across and are produced in clusters of from 10 to 15 flowers.

\section{Pruning at Planting Time}

When planting Roses be careful to prune any mangled ends of the roots, using a very sharp knife or pruning shears. Trim back all branches to not more than 3 to 6 eyes or buds and if much branched remove all but 3 or 4 of the strongest shoots. To obtain best results it is rery important that these instructions are carried out. For further information regarding the planting of Roses, see page 55.

\section{Climbing Roses}

Strong 2-year old plants, 50c each; $\$ 5.50$ per dozen; prepaid within third zone, when in dormant condition.

BANKSIA WHITE-A thornless climbing rose, with glossy ever-green foliage. The flowers are small but bloom in great profusion in Spring and early Summer.

BANKSIA YELLOW-Deep yellow blossoms.

BEAUTY OF GLAZENWOOD (San Rafael Rose, Fortune's Yellow) -A vigorous fast climber, sending forth a mass of bloom in early Spring, being a combination of copper, carmine and salmon-yellow.

CHEROKEE PINK-A beautiful single rose of a delicate clear pink color. A rigorous climber with glossy foliage.

CHEROKEE RED or RAMONA-A very rapid climbing rose with rich glossy foliage. The flowers are single and large and of a deep rosy carmine with yellow stamens.

CHEROKEE WHITE-Large single white blossoms.

CLIMBING AMERICAN BEAUTY - Cerise-red flowers, medium size, double and very fragrant. Vigorous climber and free bloomer.

CLIMBING BELLE SIEBRECHT (H. T.) - A splendid climbing rose of a brilliant pink color. The buds are long and pointed and the petals reflex in a graceful manner.

CLIMBING CAROLINE TESTOUT (H. T.) - A very quickgrowing climbing rose. The blossoms are a beautiful pink color and very large. A continuous bloomer.

CLIMBING CECILE BRUNER (P.) - A climbing sort of this well known "Baby Rose." The flowers come in clusters and bloom for a long period; color, beautiful salmon-pink, shading deeper toward the center.

CLIMBING GENERAL MacARTHUR (H. T.)-Brightest crimsoll. A true sport from the popular bush variety.

CLIMBING LA FRANCE (H. T.)-Of climbing habit, producing large silvery pink flowers in great abundance.

CLIMBING SUNBURST (H. T.) - Long buds which open to large and full flowers of a distinct and beautiful sulphur-yellow. Recommended only for warmer localities.

DOROTHY PERKINS (Wich.)-Soft shell-pink, flowering profusely in large clusters; a strong growing climber which is suitable for warmer sections only as it mil. dews in the bay region.

DR. W. VAN FLEET (Wich.) -A strong vigorous climbing rose of a delicate flesh pink.

EXCELSA (Wich.) - A small red rose produced in immense clusters. A great improvement on Crimson Rambler. Suitable for warmer sections only as it mildews in the bay region.

LA MARQUE (N.)-Pure white tinged with lemon-yellow at center. A vigorous grower.

PAUL'S SCARLET CLIMBER - The flowers are a vivid scarlet, of good size and semi-double, very freely produced in clusters on much branched canes. It is of strong climbing habit and perfectly hardy.

SILVER MOON - A strong growing climbing rose with glossy, bronzy green foliage. The single pure white flowers are very large and come in clusters.

STANDARD or TREE ROSES-See page 55. 


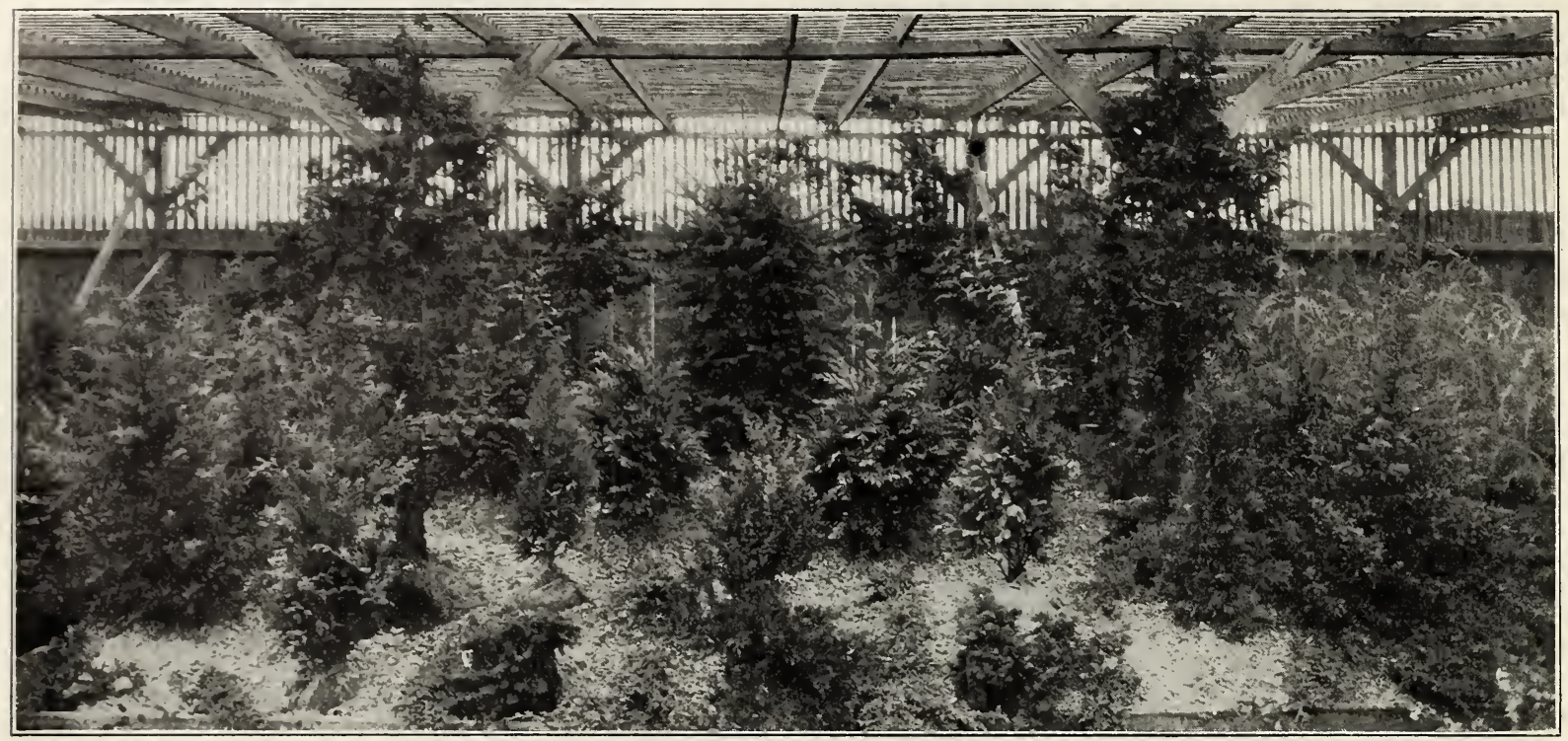

A Group of Coniferous Evergreens

\section{Coniferous Trees and Shrubs}

\section{Abies (Fir)}

NORDMANNIANA (Nordmann's Silver Fir) -A handsome and desirable species of slow growth but eventually becoming a large tree. Branches very widely spreading. Leaves are flattened, dark green and glossy above, silvery underneath. One of the very best firs. Boxed 5 to 6 feet specimen trees, $\$ 15.00$ each. Boxed 7 feet specimen trees, $\$ 20.00$ each.

PINSAPO (Spanish Fir)-A magnificent tree, very regular and symmetrical in habit. Leaves rigid, acute, entirely surrounding the branchlets; upper surface glaucous, underlaid deep green while the lower surface is marked with two conspicuous silvery lines. 6 feet specimen trees, $\$ 20.00$ each.

\section{Cedrus (Cedar)}

ATLANTICA (Mt. Atlas Cedar)-A large tree of open growth and pyramidal in form. Foliage pale or bluish green. 5 gallon cans, 3 to 4 feet, $\$ 5.00$ each. Balled, 6 to 7 feet, $\$ 7.50$ each.

DEODORA (Indian or Himalayan Cedar) - Exceedingly handSome: branches are drooping, with silvery-green foliage; fine 5 feet, $\$ 6.00$ each. Balled, 6 feet, $\$ 7.50$ each.

IIBANI (Cedar of Lebanon)-Vigorous grower; wide spreading, horizontal branches. Foliage dark green. Balled, 4 feet, $\$ 5.00$ each. Balled, 6 feet, $\$ 7.50$ each.

\section{Chamaecyparis}

(Flat Branched Cypress)

LAWSONIANA (Lawson Cypress)-A native of Oregon and California. A beautiful tree which is tall and slender except at the base. Has elegant drooping branches and very slender, feathery branchlets, Foliage usually more or less glaucous. Tip of tree always droops. 5 feet trimmed pyramidal specimens, $\$ 5.00$ each. Balled, 6 feet trimmed pyramidai specimens, $\$ 7.50$ each.

LAWSONIANA ALUMI (Blue Lawson Cypress)-Of dense growth and columnar habit. Foliage very glaucous, with a bluish metallic hue. Balled 3 feet, $\$ 3.00$ each. Balled 4 feet $\$ 5.00$ each. Balled, $41 / 2$ to 5 feet specimens, $\$ 7.50$ each. Balled 6 feet specimens, $\$ 12.00$ each.

LAWSONIANA ERECTA VIRIDIS-A handsome variety, differ ing in its color and compact habit. The branchlets all stand vertically and close together and the foliage is a clear rich green. Develops very symmetrically into a beautiful specimen for individual planting. Balled 2 to $21 / 2$ feet, $\$ 3.00$ each. Balled, 3 feet, $\$ 6.00$ each. Balled $3 \frac{1}{2}$ feet $\$ 7.50$ each.

\section{Cryptomeria}

ELEGANS-A low dense tree with horizontal branches and pen dulous branchlets. The foliage turns bronzy crimson in the fall and retains this tint throughout the winter. Balled 3 feet specimen trees, $\$ 3.50$ each.

\section{Cupressus (Cypress)}

MACROCARPA (Monterey Cypress)-A native of California, and one of the most desirable of evergreens; stands pruning well; very extensively planted for hedges. Transplanted in flats of about 100 plants for $\$ 4.00$. 3 inch pots $1 \mathrm{t} / 2$ feet, $25 \mathrm{c}$ each; $\$ 2.00$ per 10. Gallon cans $2^{1 / 2}$ to 3 feet, $60 \mathrm{c}$ each, $\$ 5.50$ per 10.

NIDIFERA (Bird's Nest Cypress)-A dwarf spreading variety, of compact habit with feathery foliage, $1 \frac{1}{2}$ to 2 feet spread. Specimen plants, $\$ 5.00$ each.

SEMPERVIRENS FASTIGIATA (Italian Cypress)-A tall slender tree of upright, pyramidal growth. A useful subject for gateways, arches, etc. Gallon cans, 3 feet, $\$ 1.00$ each. Balled, 4 to 5 feet, $\$ 2.50$ each. Balled, 5 to 6 feet, $\$ 3.00$ each. Balled, 6 to $7 \mathrm{ft}$., $\$ 4.00$ each.

\section{Juniperus (Juniper)}

CHINENSIS PROCUMBENS (Japanese Creeping Juniper)-A prostrate creeping variety with dense compact blue green foliage. Fine for rockeries, borders or ground cover. Balled, 1 foot spread, \$1.00 each. Balled, 11/2 feet spread, $\$ 1.50$ each. Balled, 2 feet spread, $\$ 2.00$ each. Balled, $2 \frac{1}{2}$ to 3 feet spread, $\$ 3.00$ each.

COMMUNIS HIBERNICA (Irish Juniper)-Distinct and beautiful, of a slender, erect, dense columnar growth; foliage very glaucous. Fine for using near columns and doorways where great height is not desired. Balled, 4 feet, $\$ 4.00$ each.

EXCELSA STRICTA (Upright Juniper)-A handsome compact shrub, wide at base and tapering at the top; color silvery gray green, of great merit in coniferous groupings owing to color and habit. Balled 2 to $2 \mathrm{r} / 2$ feet, $\$ 3.00$ each. Balled, $2 \frac{1}{2}$ to 3 feet, $\$ 3.50$ each.

SABINA TAMARISCIFOLIA (Tamarisk Ieaved Juniper)-A very fine creeping variety seldom more than 1 foot high and attaining a spread of 6 or 8 feet, making a dense compact mat of gray-green foliage which never changes color. Balled, 3 feet, $\$ 3.50$ each. 
HALLAWELL SEED CO. CONIFEROUS EVERGREENS SAN FRANCISCO, CALIF.

\section{Libocedrus}

DECURRENS (Incense Cedar)-A native tree of the California mountains and one of our finest evergreen trees. Makes a tall, narrow, pyramidal or columnar tree with deep green lustrous foliage, very dense and compact. Balled, 4 feet, $\$ 3.50$ each.

\section{Picea (Spruce)}

GLAUCA (White Spruce) - A compact, symmetrical tree with rather light bluish green foliage; bears very small cones. Boxed 8 feet specimen trees, $\$ 20.00$ each.

ORIENTAIIS (Oriental Spruce)-The most graceful of all the spruces. About the same color as Norway Spruce, but with more slender branches, shorter leaves and far more compact. Grows very slowly and is the best variety for small grounds. Boxed 6 feet specimen trees, $\$ 15.00$ each.

\section{Pinus (Pine)}

CANARIENSIS (Canary Island Pire)-One of the most beautiful and permanent of all pines for California. Extremely long needles in large tufts. The new growth is silvery white. Very fast growing. Gallon cans, $1 \frac{1}{2}$ to 2 feet, $75 c$ each.

EXCELSA (Bhotan Pine)-A magnificent tree from the Himalayas; branches spreading, slender, flexible and regularly whorled; the needle-like leaves are grayish or bluish green, 5 to 7 inches long; cones pendulous, 7 to 9 inches long. Fine as a specimen and in mass effects. 5 gallon cans, $2 \mathrm{~T} / 2$ feet, $\$ 2.00$ each.

MUGHUS (Dwarf Mugo Pine) - Desirable for rockeries, etc. Balled 1 to $1 \frac{1}{2}$ feet spread, $\$ 3.00$ each.

PINEA (Italian Stone Pine)-Tree symmetrical and compact, attaining a flat top with age; foliage deep green. Balled 3 feet, $\$ 3.50$ each.

RADIATA (Monterey Pine)—The most desirable pine for shade, and more extensively planted than any other variety in this state. 5 -inch pots, 2 feet, 60 c each; $\$ 5.50$ per 10 . Potted 4 feet, heavy stock, \$1.25 each. Potted 6 feet, heavy stock, $\$ 2.00$ each.

\section{Retinospera}

OBTUSA-A handsome tree with horizontal branches and fern-like tufts of leaves which are dark green. Of slow growth. 5 feet specimen trees, $\$ 25.00$ to $\$ 35.00$ each.

SANDERI_O O low subglobose habit with bluish gray blunt leaves, 2 feet specimens, $\$ 5.00$ each.

SQUARROSA VEITCHI (MOSS Retinospera)-Of low and very dense growth, with feathery spreading branchlets, dark bluish green in color. Resembles somewhat a large clump of soft
branching moss. Balled $11 / 2$ feet, bushy, $\$ 2.50$ each. Balled 3 feet specimens, $\$ 5.00$ each.

\section{Sequoia (Redwood)}

SEMPERVIRENS (California Redwood)-A native ornamental tree of rapid growth and of tapering pyramidal habit. Branche stand out horizontally; leaves dark green with pale bands beneath. Fine as a specimen and in mass effects. Gallon cans, 1 $1 / 2$ to 2 feet, $75 \mathrm{c}$ each. Gallon cans 2 to 3 feet, $\$ 1.00$ each. Balled 3 to 4 feet, $\$ 2.50$ each.

\section{Taxus (Yew)}

BACCATA FASTIGIATA (Irish Yew)-A slow growing tree of dense, columnar habit: foliage is of the darkest hue; bears large red berries. Balled, $1 \frac{1}{2} / 2$ feet, $\$ 2.00$ each. Balled, 4 feet, $\$ 12.00$ each

\section{Thuya (Arbor Vitae)}

OCCIDENTALIS BEVERLEYENSIS - Tall columnar slender habit; foliage which well covers the erect trunk is flattened bright green overcast with golden yellow. Especially desirable where striking formal effects are essential. Balled, 3 feet, $\$ 5.00$ each.

ORIENTALIS AUREA BERCKMANIANA (Berckman's Golden Arbor Vitae)-Dwarf compact evergreen shrub with bright golden-yellow tinted foliage, retaining its wonderful color and form under all conditions: well adapted to garden and porch ornamentation. Balled, grafted, specimen plants, 1 foot, bushy, $\$ 1.50$ each; $11 / 2$ feet, extra bushy, $\$ 2.25$ each; 2 feet, extra bushy, $\$ 3.00$ each; $2 \frac{1}{2}$ feet, extra bushy, $\$ 4.00$ each.

ORIENTAIIS COMPACTA (Compact Oriental Arbor Vitae)A bright green sort of graceful compact habit. Suitable for the garden or porch decoration. Balled, specimen plants, $2^{1 / 2}$ feet, \$3.00 each; 3 feet, extra bushy, $\$ 4.00$ each; $3^{1 / 2}$ to 4 feet, extra bushy, $\$ 5.00$ each.

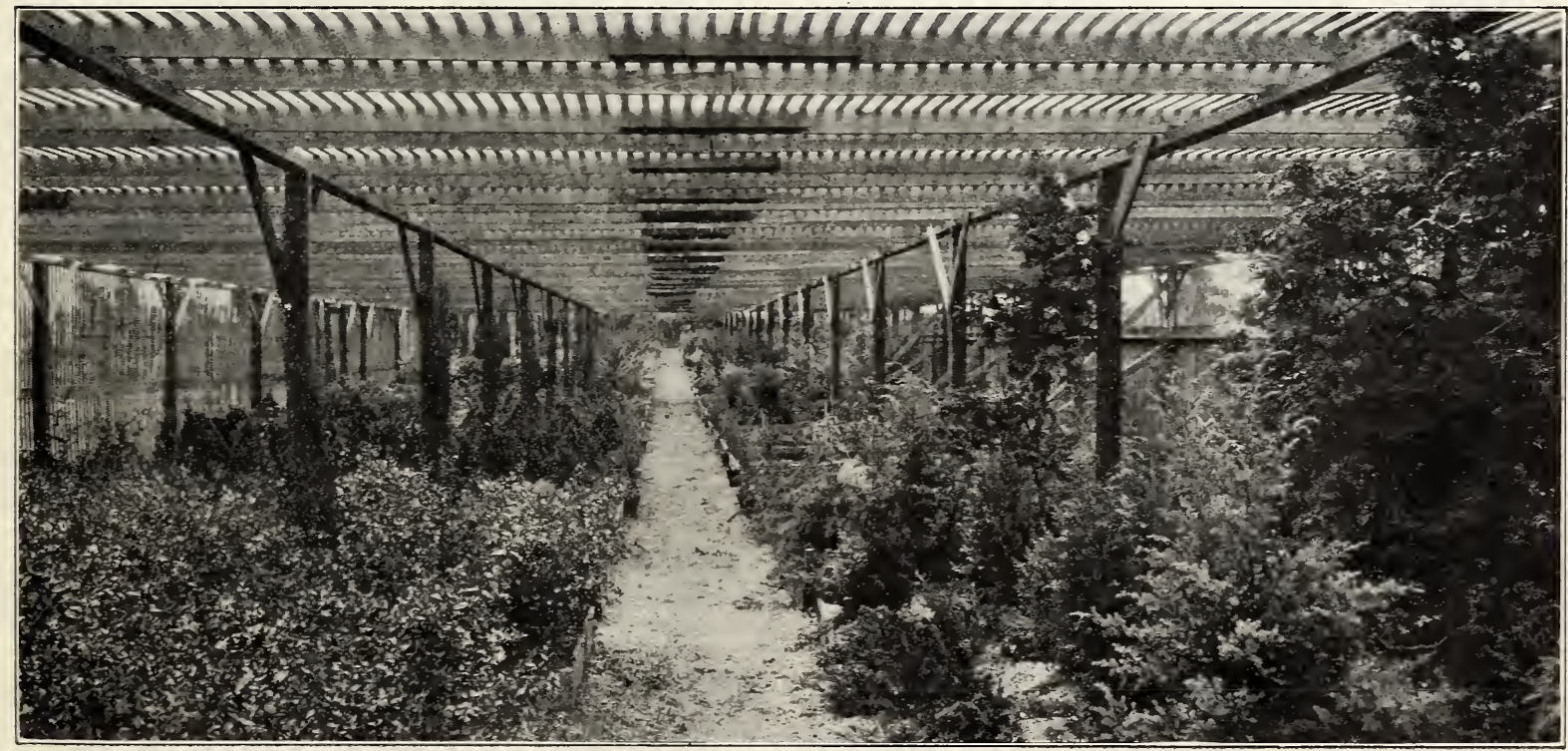

View of one of our Lath Houses 


\section{Evergreen Trees and Shrubs}

Transportation charges on Evergreen Trees and Shrubs are to be paid by customer.

Please give name of express and freight offices where they differ from postoffice.

Potted plants are taken from pots when shipped.

"Balled" means that the plants are taken from the ground with a ball of soil around the roots.

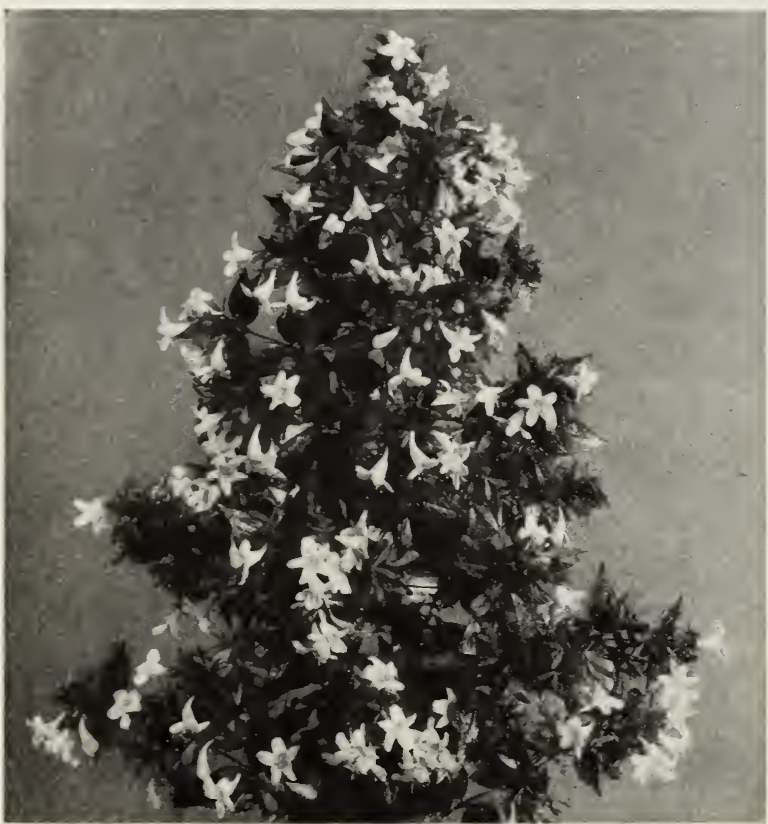

Abelia Grandiflora

\section{Abelia Grandiflora}

A pretty free-flowering shrub, remaining in bloom during the entire Summer, bearing fragrant tubular flowers almost one inch long. white flushed pink. Balled, $1 \frac{1}{2}$ feet, $75 \mathrm{c}$ each. Balled, 2 feet, $\$ 1.00$ each. Balled, $2 \frac{1}{2}$ to 3 feet, $\$ 1.50$ each.

\section{Acacia}

Highly ornamental and decorative, rapid growing shrubs and trees which are natives of Australia and very hardy.

ARMATA (Kangaroo Thorn)-A spreading shrub with long slender branches. Small deep green leaves with a small sharp thoril at each leaf; flowers light yellow, borne all along the branches: blooms in February. 5 -inch pots, 2 to 3 feet, $60 \mathrm{c}$ each; $\$ 5.50$ per 10.

BAIIEYANA -Very ornamental tree, with bluish-green feathery foliage and covered with a mass of bright canary-yellow flowers in January. Gallon cans, 4 to 5 feet, $\$ 1.25$ each. Gallon cans, 6 feet, $\$ 1.50$ each.

FLORIBUNDA-A rapid-growing tree of pendulous habit, with long, narrow foliage; flowers come in racemes of bright yellow, blooming throughout the Sumner; useful for avenue and street planting. 5-inch pots, 4 feet, $60 \mathrm{c}$ each; $\$ 5.50$ per 10.6 -inch pots, 6 to 7 feet, $\$ 1.00$ each; $\$ 9.00$ per 10 .

LATFOLIA_Used extensively in Golden Gate Park for winclbreaks and is also a valuable hedge plant; leave are long and flowers golden yellow. 5 -inch pots, 4 to 5 feet, $75 \mathrm{c}$ each; $\$ 7.00$ per 10. 6 -inch pots, 5 to 6 feet, $\$ 1.00$ each; $\$ 9.00$ per 10 .

\section{Acacia-Continued}

MELANOXYLON (Blackwood Tree)-Valuable for sidewalk or avenue trees; it has few equals, being of very rapid growth, and it can be trimmed so as to make beautiful specimens. Flowers pale yellow, blooms in March. 6 -inch pots, 6 to 7 feet, $\$ 1.00$ each; $\$ 9.00$ per 10.5 gallon cans, 6 feet, headed for street planting, \$2.50 each.

MOLLISSIMA-A fine, erect-growing tree, with dark green, feathery foliage: flowers yellow, produced from December to March in great profusion; a rapid-growing tree. Gallon cans, 5 to 6 feet, $\$ 1.00$ each. Gallon cans, 6 to 7 feet, $\$ 1.25$ each.

VERTICILATA-A spreading shrub with fine needle-like leaves; flowers deep yellow, blooms in April and May. Fine for grouping. 5 -inch pots, 2 to 3 feet, $60 \mathrm{c}$ each; $\$ 5.50$ per 10 . 6 -inch pots, 3 to 4 feet, $75 \mathrm{c}$ each.

\section{Alsophila (Australian Tree Fern)}

AUSTRAIIS-A very graceful and rapid growing tree fern, with finely divided fronds of a pleasing shade of light green. Plant in a sheltered and partially shaded location. 5-gallon cans, $\$ 7.50$ each.

HARDY FERNS-Suitable for shady locations, in a good assortment at $75 \mathrm{c}$ each and $\$ 1.00$.

\section{Arbutus (Strawberry Tree)}

UNEDO-A moderate sized shrub, with clean, attractive foliage. White flowers appear in winter months and with them the large, red, strawberry-like fruits of the previous season, 6-inch pots, $1 \frac{1}{2}$ feet, $75 \mathrm{c}$ each; 6 -inch pots, 2 feet, $\$ 1.00$ each. Balled, 3 feet, extra bushy, $\$ 3.00$ each. Balled, 4 feet, extra bushy, $\$ 3.50$ each.

\section{Aucuba}

JAPONICA - This shrub is sometimes called the "Gold Dust Tree," on account of its large, glossy foliage marked with yellow spots. Of slow spreading growth. In the warmer sections it should have partial shade. Fine for porch decorations. Balled, $\$ 1.25$ each and $\$ 1.50$ each.

SERRATIFOLIA-Of similar habit to the above, with dark green, toothed leaves. Balled $\$ 1.25$ each and $\$ 1.50$ each.

\section{Azalea}

HINODIGIRI (Japanese Evergreen Azalea) - Flowers bright red, appearing very early in the season; of dwarf habit. Balled, $\$ 1.50$ each and $\$ 2.00$ each.

\section{Azara Microphylla}

A graceful shrub with arching pendulous branches and small dark green glossy leaves Has minute white flowers. Fine for covering walls or fences. Balled, 2 to 3 feet, $\$ 1.50$ each. Balled, 3 to 4 feet, $\$ 2.00$ each. Balled, 4 to 5 feet, $\$ 2.50$ each.

\section{Banana (Musa Ensete)}

ABYSSINIAN-Fine for gorgeous tropical effects. Foliage extremely large and bright green. Requires a sheltered situation and will not stand much frost. 6 -inch pots, 2 feet, $\$ 1.50$ each.

\section{Berberis (Barberry)}

DARWINII-A densely branched, spreading shrub, with thick and leathery foliage; flowers orange-yellow and very fragrant, followed by purple fruit; the best of the species. 4-inch pots, $40 \mathrm{c}$ each; $\$ 3.50$ per $10 ; 5$-inch pots, $60 \mathrm{c}$ each; $\$ 5.50$ per $10 ; 6$-inch pots, $75 \mathrm{c}$ each; $\$ 6.50$ per 10 . Balled, 2 to $2 \frac{1}{2}$ feet, $\$ 1.25$ each. Balled, $2 \frac{1}{2}$ to 3 feet, $\$ 1.50$ each.

VERRUCULOSA-A very handsome, new variety from China. 3 feet tall. Of beautiful compact form with lustrous, deep green leaves and conspicuous slender spines; flowers light yellow followed by violet-black fruit. Balled, $1 \frac{1}{2}$ to 2 feet spread, $\$ 1.50$ each. Balled $2 \frac{1}{2}$ feet spread, \$2.00 each.

WILSONAE-An introduction from western China, of very dwarf hakit with small glossy green leaves and long spines. The foliage in the Fall assumes beautiful red tints; has attractive red berrries in the Winter. Balled, 9 to 12 inches, $60 \mathrm{c}$ each. Balled, $1 \frac{1}{2}$ to 2 feet, $\$ 1.50$ each. For other varieties, see page 68 . 


\section{Cestrum}

AURANTIACUM-A strong growing shrub, blooming in the Fall and early Winter. The orange-yellow tube-shaped flowers are $1 \frac{1}{2}$ inches long and are borne in clusters, followed by snowwhite berries. 5 -inch pots, 60c each.

FASCICUIATUM - A quick-growing shrub of tall and slender habit. The bright red flowers are trumpet-shaped and are borne in compact clusters at the ends of the branches. 10 feet high. 5 -inch pots, $60 \mathrm{c}$ each.

\section{Choisya Ternata (Mexican Orange)}

A compact low-growing shrub with glossy bright-green leaves which are divided into three leaflets, fragrant when crushed, bearing clusters of small white fragrant flowers on the tops of the branches. Balled, 1 foot, bushy, $\$ 1.00$ each. Balled, $1 \frac{1}{2} 2$ to 2 feet, extra bushy, $\$ 1.50$ each.

\section{Chorizema Ilicifolium}

An attractive spring flowering shrub, with slender, drooping branches, orange-red, pea-shaped flowers in loose racemes, and holly-like leaves. Native of Australia, 3 feet high. Pot grown, 50c each and $75 \mathrm{c}$ each.

\section{Cistus (Rock Rose)}

AIBIDUS-Foliage woolly white. Flowers lilac-pink, 2 to 3 inches wide. Blooms continuously; very resistant to drought. 4 -inch pots, $35 \mathrm{c}$ each.

LADANIFERUS MACUIATUS-A free flowering dwarf shrub with showy flowers similar to a single rose, appearing in early. summer. Pure white with brownish crimson spot at base of each petal. 5-inch pots, $60 \mathrm{c}$ each.

\section{Coprosma}

BAUERI-A compact-growing shrub which can also be used as a low climber. Leaves are rounded and green and very glossy. 4 per 10. 6 -inch pots, 75 c each; $\$ 6.50$ per 10 . Balled $11 / 2$ to 2 feet, $\$ 1.00$ each.

BAUERI VARIEGATA-Similar to the above except that the leaves have a broad yellow margin. Pot grown, $75 \mathrm{c}$ each and

Buddleia Magnifica \$1.00 each.

\section{Buddleia}

VARIABIIIS MAGNIFICA-Commonly known as the Butterfly Bush or Summer Lilac. Attains a height of 10 to 15 feet and produces large drooping panicles of purplish-violet flowers in great profusion all Summer. 5 -inch pots, $1 \frac{1}{2}$ to 2 feet, $50 \mathrm{c}$ each. 6 -inch pots, 2 to 3 feet, $75 \mathrm{c}$ each.

GLOBOSA-Ball-shaped, orange-yellow flowers in dense clusters at the ends of the branches. Gallon cans $60 \mathrm{c}$ each and $75 \mathrm{c}$ each. BREATH OF HEAVEN-See Diosma, page 64. BROOM_See Genista, page 65 .

BURNING BUSH_See Pyracantha, page 67

\section{Boxwood or Buxus}

SEMPRRVIRENS-Trimmed, cone shaped. For porch decoration, Balled, 2 feet, $\$ 2.50$ each.

SUFFRUTICOSA (Dwarf Boz)-Balled, 12 inches, $75 \mathrm{c}$ each. SUFFRUTICOSA_Dwarf, for edging purposes. Light, 60c per 10; $\$ 5.00$ per 100 . Heavy, $75 \mathrm{c}$ per $10 ; \$ 6.00$ per 100 .

\section{Callistemon (Bottle Brush)}

RIGIDA-A showy flowering shrub with red flowers which are the exact shape of a bottle brush. Often known as Mfetrosideros. Gallon cans, 3 feet, $75 \mathrm{c}$ each.

\section{Camellia}

Beautiful Winter-flowering evergreens, with shining dark-green foliage and magnificent wax-like flowers blooming very profusely all Winter. Should be grown in a partially shaded, well sheltered location. Quite hardy.

DOUBLE ROSE PINK-Potted, 1 foot, $\$ 1.50$ each. Potted, $1 \frac{\mathrm{t}}{2}$ feet, $\$ 2.00$ each. DOUBLE RED-Potted, 1 foot, $\$ 1.50$ each.

\section{Cassia Tomentosa}

A large shrub of very strong and erect growth. Leaves, pinnate: flowers yellow, saucer shaped. Extremely free flowering. Pot grown. $50 \mathrm{c}$ each and $75 \mathrm{c}$ each.

\section{Ceanothus (California Wild Lilac)}

THYRSIFLORUS-A native shrub with small dark glossy green

leaves. Flowers pale blue. 5 -inch pots, $1 \frac{1 / 2}{2}$ to 2 feet, $75 \mathrm{c}$ each. For other varieties, see page 68 .

CHRISTMAS BERRY_See Phótinia, page 67 .

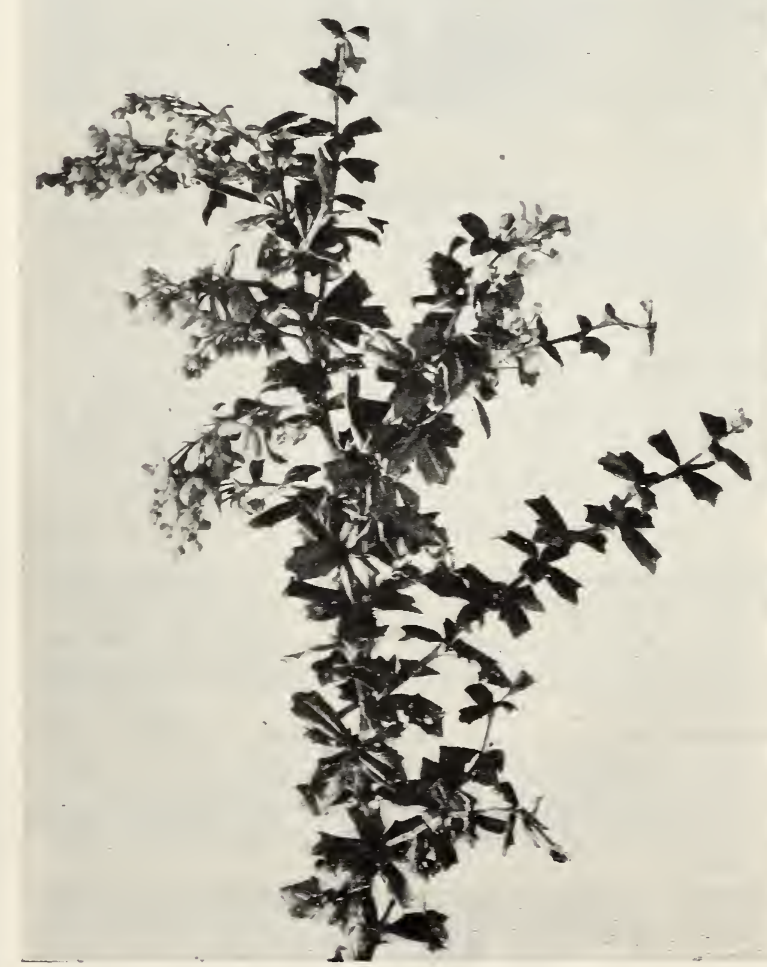

Berberis Darwinii

for description, see page 62 . 


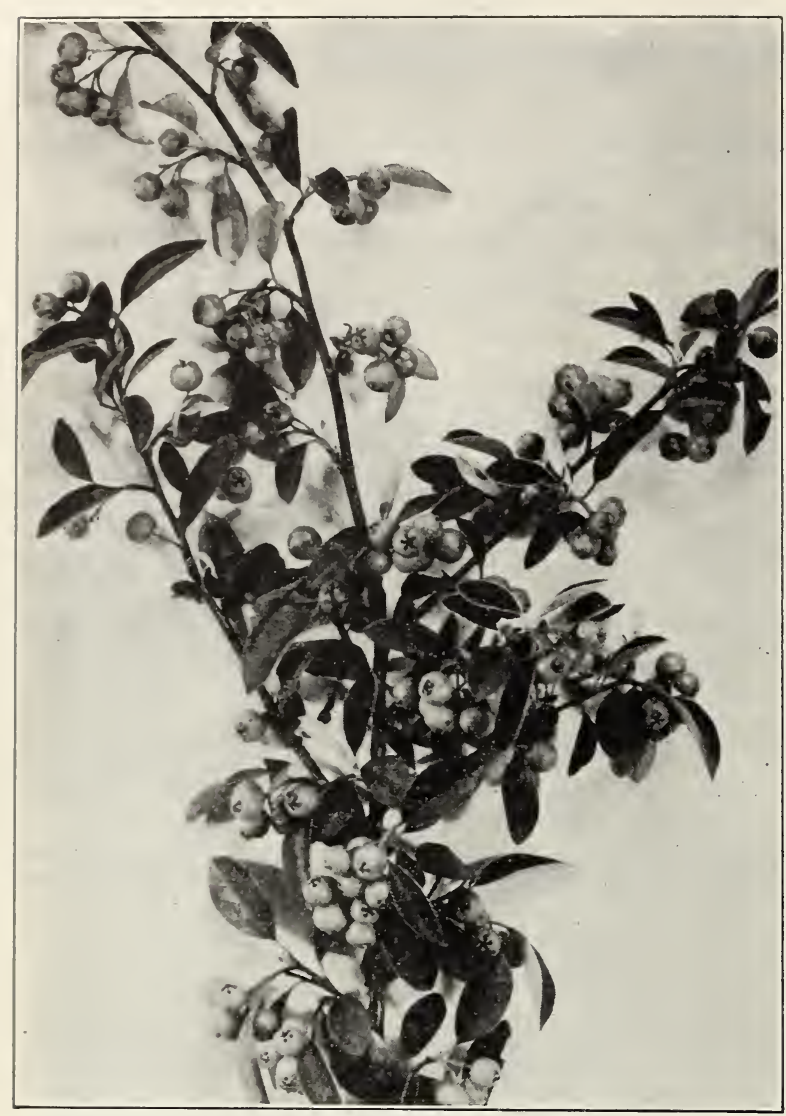

Cotoneaster Pannosa

\section{Cotoneaster}

Ornamental shrubs with orange or red berries remaining on throughout the whole Winter; some are of upright growth and others of low-spreading habit.

ACUMINATA (C. Nepalensis)-Erect growth, 6 feet tall; flowers slightly pinkish, followed by large oblong deep red berries. Balled, 3 feet, $\$ 1.00$ each. Balled, 3 to 4 feet, $\$ 1.25$ each.

FRANCHETI-A graceful shrub of upright growth and very arching branches, leaves are downy; 8 feet tall. Flowers pink, followed by yellowish-red berries. 4 -inch pots, 40 c each; $\$ 3.50$ per 10. 6 -inch pots, 2 feet, 75 c each, $\$ 6.50$ per 10 . Balled, 3 feet, $\$ 1.50$ each.

HARROVIANA (New)-Tall, graceful branching habit; flowers white and berries, which are borne in large masses, are rosy
red. 5-inch pots, 60c each; $\$ 5.50$ per 10.6 -inch pots, $75 \mathrm{c}$ each; red. 5 -inch po
$\$ 6.50$ per 10 .

HORIZONTAIIS - A small-growing shrub of low-spreading habit; small round foliage, flowers small white, appearing in May and followed during the Fall and Winter months by bright red berries, 4-inch pots, $40 \mathrm{c}$ each; $\$ 3.50$ per 10 . 5 -inch pots, $60 \mathrm{c}$ each; $\$ 5.50$ per 10 . 6 -inch pots, $75 \mathrm{c}$ each; $\$ 6.50$ per 10 . Balled $11 / 2$ to 2 feet spread. $\$ 1.00$ each. Balled, 2 to 3 feet spread, $\$ 1.50$ each.

MICROPHYLLA - A small growing evergreen variety of lowspreading habit; leaves small, glossy and very dark green; flowers small white, followed by large purplish-red berries in pots, $60 \mathrm{c}$ each; $\$ 5.50$ per 10 . 6 -inch pots, $75 \mathrm{c}$ each; $\$ 6.50$ per 10 Balled, $11 / 2$ to 2 feet spread, $\$ 1.00$ each; Balled, 3 feet spread, $\$ 1.50$ each.

PANNOSA-A fine shrub of upright growth, 10 feet tall, Branches long, slender and slightly arching; leaves deep green and covered with silvery down beneath, covered with vermilion red berries in the Fall. 5 -inch pots, $60 \mathrm{c}$ each; $\$ 5.50$ per 10 . 6-inch pots, 2 to 3 feet, 75 c each; $\$ 6.50$ per 10 . Balled, 3 to $31 / 2$ feet, each.
CRATAEgUS OR BURNING BUSH-(See Pyracantha on page 67.)

\section{Daphne Odorata}

These beautiful, low-growing shrubs have dark green leaves and small flowers in clusters which are very sweet scented and appear in early Spring. Pink, variegated leaves. Balled, $11 / 2$ feet, bushy, $\$ 2.50$. Balled, $1 \frac{1}{2}$ to 2 feet, extra bushy, $\$ 3.00$ each. White, plain green leaves. Balled, $11 / 2$ feet, bushy, $\$ 2.50$ each.

\section{Diosma, Breath of Heaven}

ERICOIDES-This handsome little shrub produces small white star-shaped flowers in great profusion. The foliage, when bruised, is very fragrant. Pot grown, 50c each and 75c each. Balled, 15 inches, extra bushy, $\$ 1.00$ each. Balled, $1 \frac{1}{2}$ feet, extra bushy, $\$ 1.25$ each. Balled, 2 feet, extra bushy, $\$ 1.50$ each.

\section{Dracaena or Dragon Palm}

AUSTRAIIS-A fine plant for outdoor planting in California, and much in use for lawns, avenues and parks. Balled, 3 feet, $\$ 2.50$ each. Balled, 4 feet, $\$ 4.00$ each. Balled, 5 feet, $\$ 5.00$ each.

\section{Eleagnus (Oleaster)}

PUNGENS ARGENTEA-Silverberry. 6 feet tall. A fine erect, spreading shrub with leaves and stems covered with frosty, shiny scales, silvery on upper surface and bronzy beneath, Leaves have a creamy white nargin. Berries are silvery. Balled, 2 feet, $\$ 2.00$ each. 5 gallon cans, 3 feet, $\$ 2.50$ each.

\section{Erica (Heather)}

Dwarf, compact, evergreen shrubs, with feathery foliage producing small, wax-like flowers in great profusion from late in the Fall until early Spring.

MEDITERRANEAN - One of the prettiest of all heaths, with feathery foliage, producing purplish pink flowers in early Spring. Balled, 12 inches, bushy, 60c each. Balled, 15 inches, bushy, $75 c$ each. Balled, $11 / 2$ feet, bushy, $\$ 1.00$ each. Balled, 2 feet, bushy, $\$ 1.25$ each. Balled, 2 fett, extra bushy, $\$ 1.50$ each.

MEDITERRANEAN HYBRIDA - Dwarf, compact growth, not over 12 or 15 inches in height. Purplish pink flowers. Balled, 9 inches, 60c each.

MELANTHERA - A beautiful variety with rosy-pink flowers. Balled, 12 to 15 inches, bushy. 60c each. Balled, $1 \frac{1 / 2}{2}$ feet, bushy, $75 \mathrm{c}$ each. Balled $11 / 2$ to 2 feet, bushy, $\$ 1.00$ each. Ballec.. 2 feet, extra bushy, $\$ 1.50$ each. Balled, $2 \frac{1}{2}$ feet, extra bushy, $\$ 2.00$ each.

REGERMINANS - A new and fine variety with rosy colored flow. ers, borne in great profusion throughout the Fall and Winter. Balled, 15 inches, extra bushy, $\$ 1.25$ each. Balled, $1 \frac{1}{2}$ feet, extra bushy, $\$ 1.50$ each.

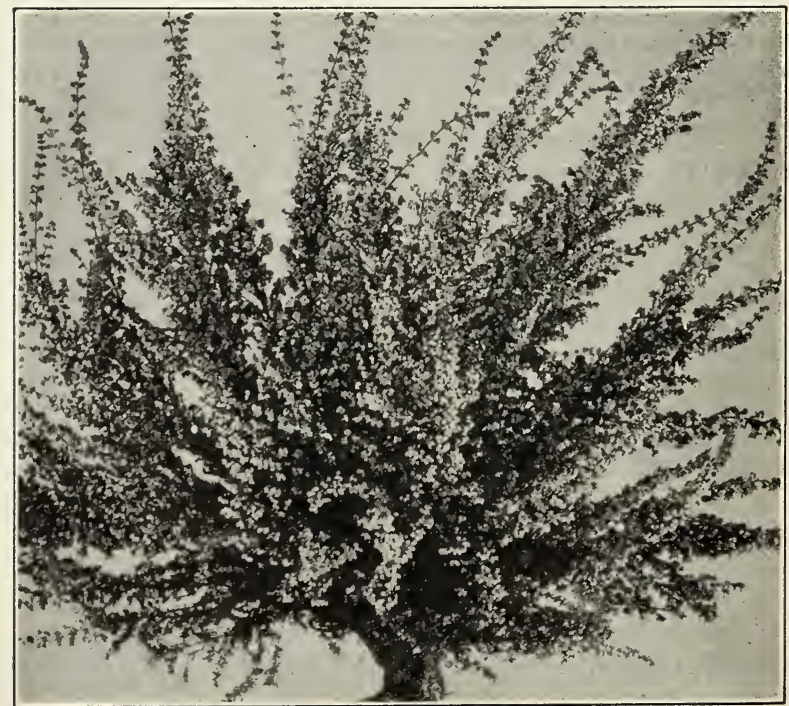

Erica Regerminans 


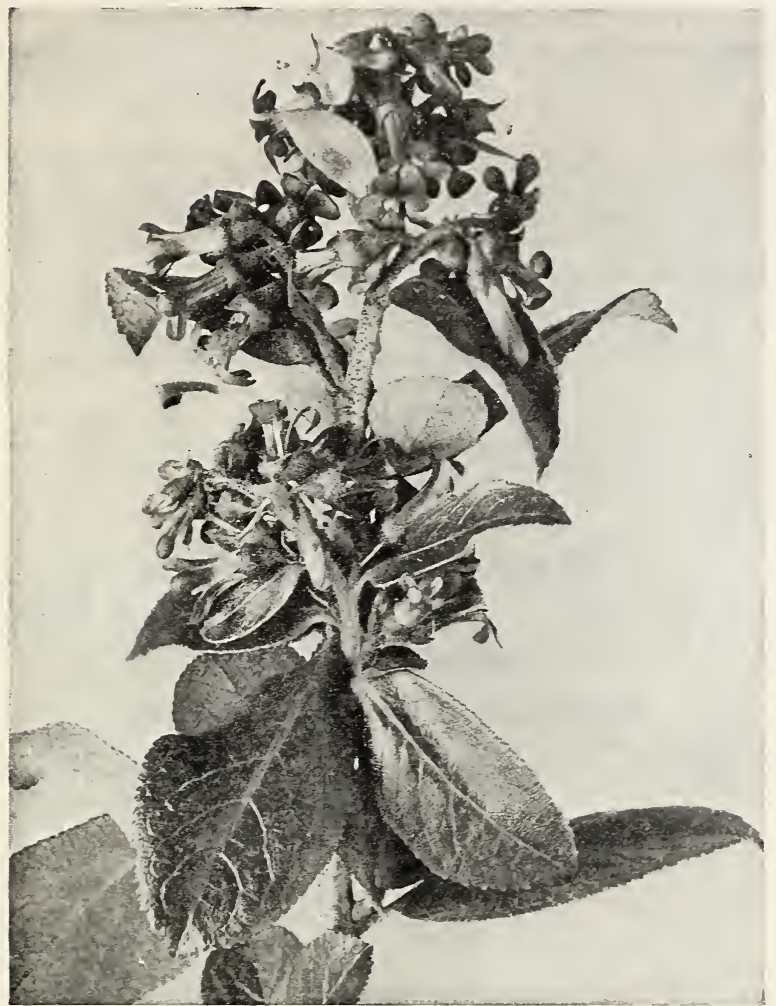

Escallonia Rubra

\section{Escallonia}

Hardy, evergreen shrubs with rounded dark, glossy green foliage, producing flowers in various colors in large terminal panicles during the entire summer.

BERTERIANA, WHITE-A compact, quick growing shrub of erect habit, 8 to 10 feet tall. Dark green glossy foliage. A continuous bloomer and one of the best shrubs for grouping. Balled, 1 to $1 \mathrm{t} / 2$ feet, $75 \mathrm{c}$ each. Balled, 2 feet, $\$ 1.00 \mathrm{each}$. Balled, 3 feet, $\$ 1.50$ each.

INGRAHAMI-A graceful shrub, flowers rose-pink in short ra cemes; foliage lustrous green. Balled 2 feet, $75 \mathrm{c}$ each. Balled, 3 feet, $\$ 1.00$ each.

ROSEA-Light pink, growing 12 feet tall. 4 -inch pots, $40 \mathrm{c}$ each; $\$ 3.50$ per 10. Balled, $11 / 2$ to 2 feet, $75 \mathrm{c}$ each.

RUBRA-Red, of compact growth, 5 feet tall. Balled, 1 foot, 75c each. Balled, $11 / 2$ to 2 feet, bushy, $\$ 1.00$ each. Balled, 2 to 3 feet, bushy, $\$ 1.50$ each.

\section{Eucalyptus}

FICIFOIIA, SCARIET-FIOWERING GUM-A beautiful sort Flowers large and normally crimson or scarlet, but vary considerably. Thick leathery leaves; hardy only in warmer sections. 6 -inch pots, 3 feet, $\$ 1.00$ each. Gallon cans, 4 feet, $\$ 1.25$ each.

GIOBULUS, BIUE GUM-The most useful variety of Eucalyptus, being of very rapid growth. Transplanted in boxes of about 100 plants for $\$ 3.50$. Pot grown, 3 feet, $40 \mathrm{c}$ each; $\$ 3.50$ per 10.

IEUCOXYION ROSEA-An ornamental variety: brilliant pink flowers, profuse Winter bloomer. 5-inch pots, 50c each; $\$ 4.50$ per 10 .

ROBUSTA, SWAMP MAHOGANY-An excellent species for low moist land, but does well under varying conditions. Very symmetrical in growth with large glossy foliage. 4 -inch pots, 2 to 3 feet, $35 \mathrm{c}$ each; $\$ 3.00$ per 10 .

\section{Eugenia}

MYRTIFOIIA-Tall shrub of compact growth, growing 15 feet tall; leaves are glossy green when fully developed, but have reddish tints on new growth; creamy white flowers followed by violet or purple berries. Balled, $31 / 2$ feet, trimmed, $\$ 3.50$ each. Balled, 4 to 5 feet, trimmed, $\$ 6.00$ each.

\section{Euonymus}

Ornamental evergreen shrubs, very desirable for hedges as they stand pruning well; also very effective when planted alone.

JAPONICUS-Dark lustrous green leaves of dense, upright habit, fine for hedges. Balled, $1 \frac{1}{2}$ to 2 feet, $75 \mathrm{c}$ each. Balled, 2 to $21 / 2$ feet, $\$ 1.00$ each.

JAPONICUS AUREO-MARGINATUS (Golden Enonymus)-Of dwarf compact growth. Leaves deep yellow toward the edges, blotched in the center with light and dark green. Does not sport back to the green type. Balled, $11 / 2$ to 2 feet, bushy, $\$ 1.50$ each. Balled, 2 to $21 / 2$ feet, bushy, $\$ 2.00$ each.

JAPONICUS ALBO-MARGINATUS (Silver IMargined Enonymus)-Leaves have a very narrow margin of silvery white. Balled, 1 to $1 \frac{1}{2}$ feet, bushy, $75 \mathrm{c}$ each. Balled, $1 \frac{1}{2}$ to 2 feet, bushy, $\$ 1.00$ each.

PULCHELIUS (Small Ieaved Euonymus)-A dwarf form of the above with small dark green foliage; excellent for a low hedge. They are usually grown 8 to 12 inches high and an occasional clipping will cause them to grow very compact. Balled, 1 foot, $60 \mathrm{c}$ each; $\$ 5.00$ per 10 .

\section{Fremontia Mexicana}

Both the flowers and foliage are larger than Fremontia Californica, which is commonly known as the California Slippery Elm. A beautiful shrub growing from 5 to 20 feet high. The flowers are large, 2 to 3 inches across, of almost an orange-yellow and are $a$ rich reddish brown on the underside. Prefers a dry location. Gallon cans 2 to 3 feet, $\$ 2.00$ each.

\section{Genista (Broom)}

These very ornamental and free-flowering shrubs will succeed in almost any soil or situation. The large pea-shaped flowers appear profusely in the Spring and Summer.

AIBA (White Broom) - A slender erect-growing shrub with grooved branches; white pea-shaped flowers. Potted, 60c each and $75 \mathrm{c}$ each.

HISPANICA (Spanish Broom)-An upright-growing shrub. Flowers yellow, produced very freely in the Spring and Summer. long, pendulous round leafless branches. 4 -inch pots, 2 feet, $40 \mathrm{c}$ each; $\$ 3.50$ per 10; 5-inch pots, $21 / 2$ to 3 feet, $60 \mathrm{c}$ each; $\$ 5.50$ per 10. 6 -inch pots, 3 to 4 feet, $75 \mathrm{c}$ each; $\$ 6.50$ per 10 .

RACEMOSA (Sweet Broom) - A very graceful variety of Broon producing its bright, golden-yellow pea-shaped flowers in the greatest profusion for a long period. Especially desirable for window boxes. 4-inch pots, $50 \mathrm{c}$ each. 5 -inch pots, $75 \mathrm{c}$ each. 6 inch pots, $\$ 1.00$ each.

SCOPARIOS (Scotch Broom) - A very handsome shrub, with drooping branches covered in the Spring with bright yellow pea-shaped flowers; very effective for grouping. 4-inch pots, $50 \mathrm{c}$ each; $\$ 4.50$ per 10. 5 -inch pots, 2 to 3 feet. 60 c each; $\$ 5.50$ per 10. 6 -inch pots, 3 to 4 feet, $75 \mathrm{c}$ each; $\$ 6.50$ per 10 .

SCOPARIUS ANDREAINA-A beautiful variety of Scotch Broom. The flowers are golden yellow with deep mahogany red wings. Pot grown, $75 \mathrm{c}$ each and $\$ 1.00$ each.

\section{Grevillea}

THELEMANNRANA-A lovely dwarf Australian shrub with fine needle-like foliage and distinct bright red flowers; very beautiful when in bloom and requires very little water. 5-inch pots, 75c each.

ROBUSTA (Australian Silk Oak)-Pot grown, 31/2 feet, $\$ 1.00$ each.

HEATHER-See Erica, page 64

\section{Holly, True English}

A small tree with glossy, dark green, thorny leaves. It is covered with bright red berries during the Winter months. Grafted stock. Specimen trees, with berries, $\$ 10.00$ each and up.

\section{Hypericum Calycinum}

A very low growing shrub about 1 foot high. Foliage dark green; flowers large, deep golden-yellow with spreading petals and numer ous long stamens, tipped with reddish anthers. Useful for ground cover, or in the margin of a shrubbery. 4 -inch pots, 35c each; $\$ 3.00$ per 10. 


\section{haLLaWELl SEed Co. SHRUBS AND TREES SAN FRANCisco, Calif.}

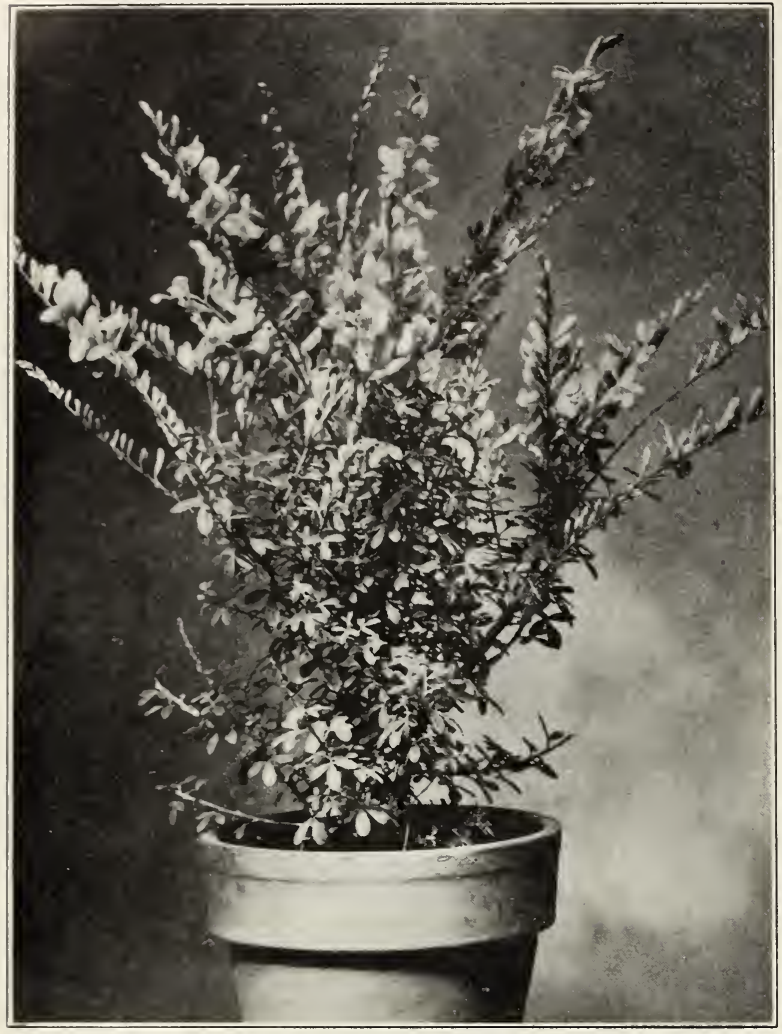

Iochroma Tubulosum

A moderate sized shrub of strong growth with downy branches. The long tubular flowers are deep blue, as many as 20 sometimes hanging in a graceful cluster. Pot grown, $75 \mathrm{c}$ each.

\section{Laurel (Prunus)}

ENGIISH-A fine evergreen, with broad, shining leaves, produc ing large panicles of creany-white flowers followed by purple

berries. Balled, $1 \mathrm{t} / 2$ feet, bushy, $\$ 1.00$ each. Balled, 2 feet,

bushy, \$1.50 each. Balled, $21 / 2$ feet, bushy, $\$ 2.00$ each. Balled, 3 feet, bushy, $\$ 2.50$ each.

PORTUGAL_Easily distinguished by its very dark green, sharply serrated leaves. Growth compact. Flowers, white, in very long slender racemes. Balled, 2 feet, bushy, \$2.00 each. Balled, $21 / 2$ to 3 feet, bushy, $\$ 2.50$ each.

\section{Laurustinus (Viburnum)}

TINUS-Shrub with wavy margined, pointed leaves. Flowers in broad heads, pinkish in bud, white when fully opened. Plant is covered with flowers during Winter and Spring. Makes a good hedge. Balled $1 \mathrm{t} / 2$ feet, bushy. $75 \mathrm{c}$ each. Balled $1 \mathrm{t} / 2$ feet, extra bushy, $\$ 1.00$ each. Balled, 2 feet, extra bushy, $\$ 1.25$ each.

\section{Leonotis Leonurus (Lion's Tail)}

A medium-sized shrub growing 6 feet tall. The orange-colored flowers which are hairy with a plush-like surface are 2 inches long and are borne in whorls around the branches during Summer and Fall. The plants are much improved by cutting back every year or so. 4 -inch pots, $35 \mathrm{c}$ each. 5 -inch pots, $50 \mathrm{c}$ each.

\section{Leptospermum (Tea Shrub)}

LAEVIGATUM-A tall evergreen drooping shrub with grayish green foliage producing great numbers of small white flowers. places. 4-inch pots, 2 feet, $40 \mathrm{c}$ especially adapted for windy 3 feet, $60 \mathrm{c}$ each, $\$ 5.00$ per 10 ; 6 -inch pots, 4 feet, $75 \mathrm{c}$ each, $\$ 6.50$ per 10.

NICHOIII_Bushy shrub with small bronze colored leaves, covered in Spring with minute dark crimson flowers. Thrives best along the sea coast. Pot grown, $60 \mathrm{c}$ each and $75 \mathrm{c}$ each.

\section{Ligustrum (Privet)}

OVALIFOIIUM (California Privet)-A valuable evergreen hedge plant. A strong growing shrub with bright medium-sized leaves. Can be kept trimmed at any height. Bare roots, 2 to 3 feet, well branched, $15 \mathrm{c}$ each; $\$ 1.00$ per $10 ; \$ 7.50$ per 100 .

OVALIFOLIUM AUREA MARGINATA (Golden Privet) Golden-margined variety. Very attractive as giving color to shrubbery groups. 5 -inch pots, $50 \mathrm{c}$ each; $\$ 4.50$ per 10 . Balled. 2 feet, $\$ 1.00$ each. Balled, 2 to 3 feet, $\$ 1.50$ each. Balled, 3 to 4 feet, extra bushy, $\$ 2.00$ each.

VULGARE (English Privet) - Hedge plant. Leaves small and dark green. Spikes of fragrant white flowers in June followed by clusters of black, shining berries. Bare roots, $1 \frac{1}{2}$ feet, well branched, $10 \mathrm{c}$ each; $75 \mathrm{c}$ per $10 ; \$ 6.00$ per 100 . Bare roots, 3 to 4 feet, well branched, $15 \mathrm{c}$ each; $\$ 1.25$ per $10 ; \$ 10.00$ per 100.

\section{Lonicera Nitida}

A compact shrub growing 3 to 6 feet high, of graceful drooping habit: with many very small leaves, Likes the sun, very hardy and should be pruned often. Fine for dwarf hedges. 4 -inch pots, $35 \mathrm{c}$ each. $\$ 3.00$ per 10 .

\section{Magnolia Grandiflora}

A grand tree, with large, broad, thick leaves which are a brilliant green on the upper surface and rusty underneath; the flowers are pure waxy white, of immense size and very fragrant. Balled, 4 to 5 feet, specimen trees, $\$ 5.00$ each.

\section{Mahonia (Oregon Grape)}

AQUIFOLIUM-A medium-sized shrub growing 6 feet high, with dark green leaves, which become coppery-purple during winter Flowers bright yellow, in slender clustered racemes followed by dark blue berries. Thrives best in partial shade. Balled, 2 to $2 \frac{1}{2}$ feet, $\$ 1.75$ each.

\section{Melaleuca}

ERICIFOLIA - Small tree or shrub with slender branches and leaves like Heather. Flowers yellowish-white. 6 -inch pots, 3 to 4 feet, 75 c each.

NESOPHILA-A fast growing shrub of erect habit with mediumsized. lance-shaped leaves. The lavender bnttle-hru $u$ are borne at the end of the branches. Thrives equally well in dry or wet soils. 4 -inch pots, 50c each.

\section{Myrtle (Myrtus)}

COMMUNIS-An evergreen shrub with aromatic foliage, producing small fragrant white flowers throughout the Summer. 4-inch pots, 40c each; $\$ 3.50$ per 10 . Balled $1 \frac{1}{2}$ feet, $75 \mathrm{c}$ each.

LUMA (Eugenia Apiculata)-Handsome slırub growing 6 feet tall. of compact growth, covered with small white flowers in Summer and Fall: foliage is small and very dark green. Balled, 15 inches, $75 \mathrm{c}$ each.

\section{Nandina Domestica}

A very handsome shrub of moderate size and rather slow growth 6 feet tall. The leaves are much divided, with rather large leaflets, light green in Summer, turning to a vivid red during the Fall and Winter. The white flowers are small in good-sized, erect panicles. followed by bright crimson berries. Balled, 2 feet, bushy, $\$ 1.50$ each. Balled, 3 feet, bushy, $\$ 2.00$ each.

\section{New Zealand Flax (Phormium Tenax)}

VARIEGATUM-Has large sword-like leaves often 6 feet or longer, which are conspicuously striped lengthwise with creamy white. It is highly decorative as a porch plant or as a specimen on the lawn. Clumps, 3 to 4 feet, $\$ 1.50$ each and $\$ 2.00$ each.

\section{Oleander (Nerium)}

Best suited for the warmer sections, where, if given plenty of water, it thrives to perfection. The flowers are produced very freely for a long period. One of the showiest of ever-blooming evergreens. All parts of the plant are poisonous if eaten.

SINGLE CRIMSON-Gallon cans, bushy, $\$ 1.00$ each. DOUBLE ROSE-Gallon cans, bushy, \$1.00 each. DOUBLE SAIMON PINR-Gallon cans, bushy, \$1.00 each.

\section{Pampas Grass (Cortaderia)}

ARGENTEA-The most widely cultivated variety with large white feathery plumes. Clumps, $\$ 1.00$ each. 


\section{Pepper Tree (Schinus Molle)}

A popular shade and ornamental tree, with fine, feathery foliage, producing clusters of reddish berries in the Fall; fine for street 0 avenue planting. Gallon cans, 3 to 4 feet, $75 \mathrm{c}$ each; $\$ 7.00$ per 10 .

\section{Pernettya}

One of the finest of the broad leaved evergreens which is becoming more popular each year. Small glossy, deep green leaves, profuse white flowers in Spring followed by large bright colored berries which remain on during Fall, Winter and Spring, giving a brilliant touch to any group.

Varieties with red and pink berries. Balled, $1 \frac{1}{2}$ to 2 feet, $\$ 2.00$ each.

\section{Photinia}

ARBUTIFOLIA (Christmas or Toyon Berry)-A native evergreen shrub loaded with brilliant red berries in the Winter. 5 inch pots, 2 feet, $\$ 1.00$ each.

\section{Pimelea Decussata}

A much branched little shrub with small leaves, closely surround ing the branches. Flowers beautiful rosy-pink, crowded in heads a the end of the shoots. Grows 3 feet high. Pot grown, 75c each and $\$ 1.00$ each.

\section{Pittosporum}

Very ornamental bright foliage plants; valuable for grouping, hedges or lawn specimens.

CRASSIFOIIUM_Valuable for windbreaks, leaves downy, dark green above and silvery beneath, flowers wine colored. 6 -inch pots, 2 to $2 \frac{1}{2}$ feet, $75 \mathrm{c}$ each; $\$ 6.50$ per 10 .

EUGENIOIDES-A large, upright growing shrub, with glossy, yellowish-green leaves; a very effective shrub, and excellent for hedges. 6 -inch pots, $60 \mathrm{c}$ each, balled. 2 to $2 \frac{1}{2} 2$ feet, extra bushy, $\$ 1.00$ each.

NIGRICANS-A very handsome upright growing shrub with silvery light green leaves and black stems; a good hedge plant and very ornamental as an individual. Transplanted in flats of about 100 plants for $\$ 5.00$. 6-inch pots, $1^{1 / 2}$ to 2 feet, $75 \mathrm{c}$ each; $\$ 6.50$ per 10. Balled, 2 to $2 \frac{1}{2}$ feet, bushy, $\$ 1.00$ each.

TOBIRA (Japanese Pittosporum) - One of the finest of the medium sized evergreen shrubs. It is a wide, spreading, dense, round headed shrub with deep, glossy, green foliage. Flowers in terminal clusters, pure whice and fragrant. Suitable for tubs as well. Selected specimen plants. 2 to $2 \frac{1}{2}$ feet spread, $\$ 2.00$ each. 3 feet spread, $\$ 2.50$ each.

UNDULATUM-A shrub or tree with deep green glossy, wavy nargined leaves. Flowers yellowish-white, intensely fragrant, particularly at night. Gallon cans; 2 feet, $75 \mathrm{c}$ each.

\section{Pleroma Macranthum}

\section{(April Delivery)}

Also known as Tibouchina and Lasiandra. A rare shrub with handsome flowers which are reddish-purple to violet, often 5 inches across. The leaves are ovate and downy. Free bloomer and half hardy. Pot grown, 75c each and $\$ 1.00$ each.

\section{Polygala Dalmaisiana}

A profuse flowering shrub with purple pea-blossom-shaped flowers. and pretty light green foliage. 5-inch pots, 60c each. 6-inch pots, $75 \mathrm{c}$ each.

PRIVET-See Ligustrum, page 66 .

\section{Pyracantha (Burning Bush)}

ANGUSTIFOIIA_Spreading growth, sometimes spiny; 8 feet tall: leaves long and narrow, green above and gray beneath. Loaded with flattened orange-yellow berries throughout the Winter. 4. inch pots, 40c each; $\$ 3.50$ per 10 . 5-inch pots, $1 \mathrm{t} / 2$ to 2 feet, $60 \mathrm{c}$ each; $\$ 5.50$ per 10.6 -inch pots, $2 \frac{1}{2}$ feet, $75 \mathrm{c}$ each; $\$ 6.50$ per 10.

CRENULATA (Chinese Evergreen Hawthorn)-Of compact habit, branches slender, leaves long, narrow and glossy. New growth very ruddy. Will endure considerable shade. 10 feet tall. Produces masses of bright scarlet berries in August 6-inch pots, $60 \mathrm{c}$ each; $\$ 5.50$ per 10 . Balled, 2 to 3 feet, $\$ 1.50$ each. Balled, 3 to 4 feet, $\$ 2.00$ each.

YUNNANENSIS - A vigorous grower of rather low, spreading habit with bright coral-red berries. 6 -inch pots, 2 feet, $75 \mathrm{c}$ each; $\$ 6.50$ per 10. 7 -inch pots, 3 feet, $\$ 1.00$ each; $\$ 9.00$ per 10 .

\section{Raphiolepis Japonica}

Handsome compact shrub of low and rather slow growth. Leaves of medium size, rounded, leathery, very dark but lustrous green. Flowers white and fragrant in early Spring, followed by dark blue berries in clusters during Winter. Balled, 1 foot, bushy, $\$ 1.00$ each.

\section{Rhododendron}

PINK PEARL-The finest of the pink-flowering varieties, carrie immense trusses of flowers. Balled, well branched plants, with flowering buds, $\$ 5.00$ each, $\$ 6.00$ each, $\$ 7.50$ each and $\$ 10.00$ each.

FIMALAYAN - A very sweet scented shrub with large, pure white flowers. Habit of growth tall and somewhat straggly. Very fine. 4 -inch pots, $\$ 1.00$ each.

STRAWBERRY TREE-See Arbutus Unedo, page 62 .

\section{Veronica}

ANDERSONI VARIEGATA-Of strong and upright growth Leaves large and conspicuously variegated with creamy-white. Flowers light blue. Balled, $1 \frac{1}{2}$ feet, bushy, 75c each.

CARNEA-A much branched variety with narrow leaves; flower rose colored; very free bloomer. Balled, $1 \frac{1 / 2}{2}$ feet, bushy, $75 \mathrm{c}$ each.

DECUSSATA - Flowers large, violet-blue. Leaves medium sized and closely set. Rather dwarf. Balled, 1 foot spread, $50 \mathrm{c}$ each $\$ 4.50$ per 10 . Balled, $1 \frac{1}{2}$ feet spread, $75 \mathrm{c}$ eacn.

IMPERIALIS-Large amaranth-red flowers. Leaves large, dark green with purple margins and midribs. A strong grower and very handsone. Balled, 1 foot, 50c each; $\$ 4.50$ per 10. Balled, $1 \frac{1}{2}$ feet, bushy, $75 \mathrm{c}$ each.

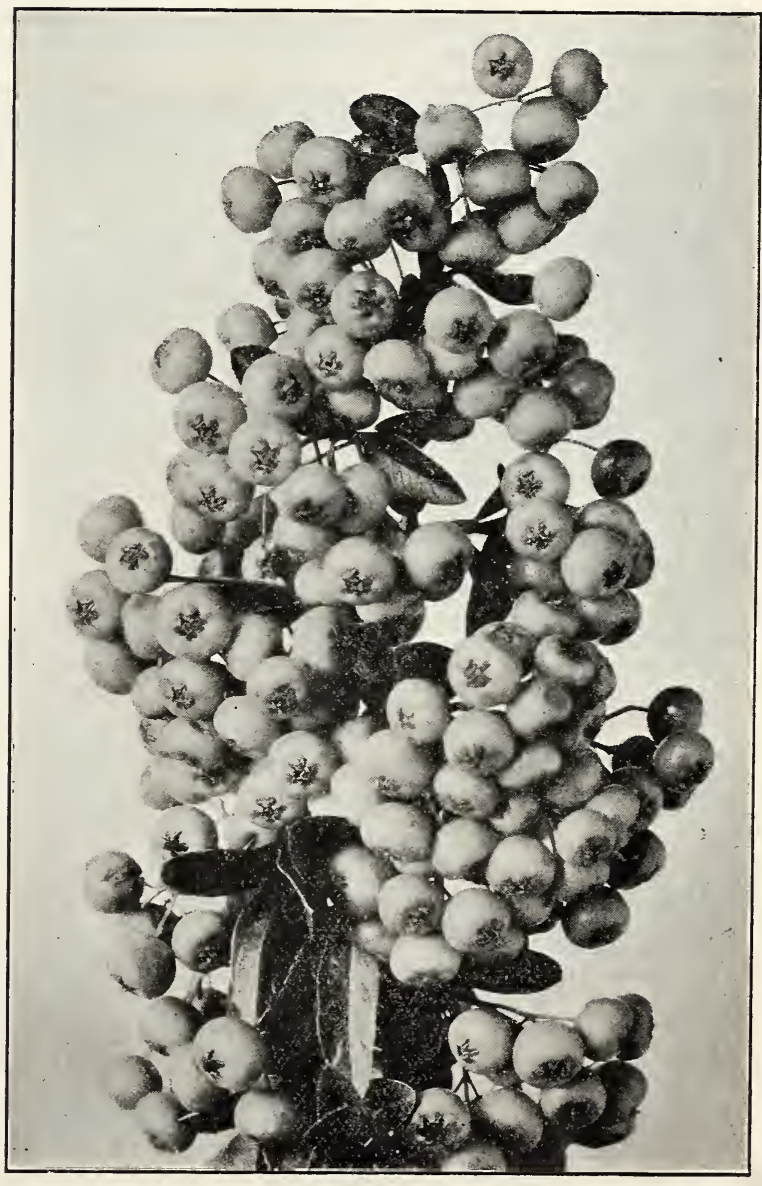

Pyracantha (Burning Bush) 


\section{Deciduous Trees and Flowering Shrubs}

Transportation charges on Deciduous Trees and Flowering Shrubs are to be paid by customer. Please give name of express and freight offices when they differ from postoffice.

\section{Dwarf Flowering Almond}

A beautiful flowering shrub growing 6 feet high, with slender branches bearing very double flowers in utmost profusion, vers early in the spring.

DOUBLE PINK-Bare roots, 3 to 4 feet, $\$ 1.25$ each. DOUBIE WHITE-Bare roots, 3 to 4 feet, $\$ 1.25$ each.

\section{Azalea Altaclarence}

A showy shrub of medium size, preterring a partially shaded location. Flowers are bright orange-yellow and the foliage is large and brilliantly colored in the Fall. $1 \frac{1}{2}$ to 2 feet, well branched, $\$ 2.00$ each.

\section{Berberis (Barberry)}

THUNBERGII-A beautiful variety with small foliage, assuming varied tints in Autumn; has attractive scarlet berries in the

Winter. Bare roots, 2 to $2 \frac{1}{2}$ feet, $60 \mathrm{c}$ each; $\$ 5.50$ per 10. For other varieties of Berberis see page 62 .

\section{Birch}

EUROPIAN-Very graceful tree, with silvery bark and slender branches: fine for avenue planting. Bare roots, 6 to 8 feet, $\$ 1.50$ each.

CUT-IEAF WEEPING-Very attractive, with tall, slender, graceful, drooping branches, delicately cut foliage and silvery bark; very handsome as a single specimen on a lawn or when planted in groups of three. Bare roots, 5 to 6 feet, $\$ 2.00$ each; 6 to 8 feet, $\$ 2.50$ each.

\section{Caryopteris Incana (Blue Spiraea)}

A low-growing shrub, bearing blue flowers in great profusion the whole length of its branches; bloons in late Summer and Fall. Bare roots, $1 \frac{1}{2}$ to 2 feet, $60 \mathrm{c}$ each. Bare roots, 2 to 3 feet, bushy, 75 c each.

\section{Ceanothus}

ROSEA SUPERBA-A very desirable shrub of easy culture, with compact, showy panicles of bright pink flowers. In bloom nearly all Summer. Balled, 2 to 3 feet, $\$ 1.50$ each.

\section{Flowering Cherry}

DOUBLE PINK - A small growing tree producing pink semidouble flowers in large clusters in early Spring before the leaves appear. Bare roots, 4 to 5 feet, branched, $\$ 2.50$ each.

JAPANESE WEEPING - The branches are very slender and gracefully drooping. The single flowers are rose-pink, borne all along the branchlets early in Spring before the leaves appear. Bare roots, $\$ 4.00$ each and $\$ 5.00$ each.

\section{Flowering Crab Apple (Pyrus)}

BETCHELI'S-A low-growing tree, well adapted for the lawn or for planting with low-growing shrubs; covered in early Spring with large, beautiful double, fragrant flowers of a delicate pink color. Bare foots, 4 to 5 feet, $\$ 1.50$ each.

FLORIBUNDA (Japanese Crab) - Flowers single, carmine in bud, pale flesh when open. Vigorous grower ard free bloomer, 6 to 8 feet. $\$ 1.50$ each.

SCHEDECRERI-A low growing tree of strong growth. Flowers semi-double, deep purplish red in bud. Shell-pink when open. Bare roots, 5 to 6 feet, $\$ 1.50$ each.

\section{Crape Myrtle (Lagerstroemia)}

A very strong-growing shrub. The leaves are bright green. The flowers with their pretty crimped petals are produced in very large panicles at the ends of the branches during the entire Summer.

PINK AND CRIMSON-Gallon cans 3 to 4 feet, $\$ 1.50$ each. Gallon cans, 4 to 5 feet $\$ 1.75$ each.

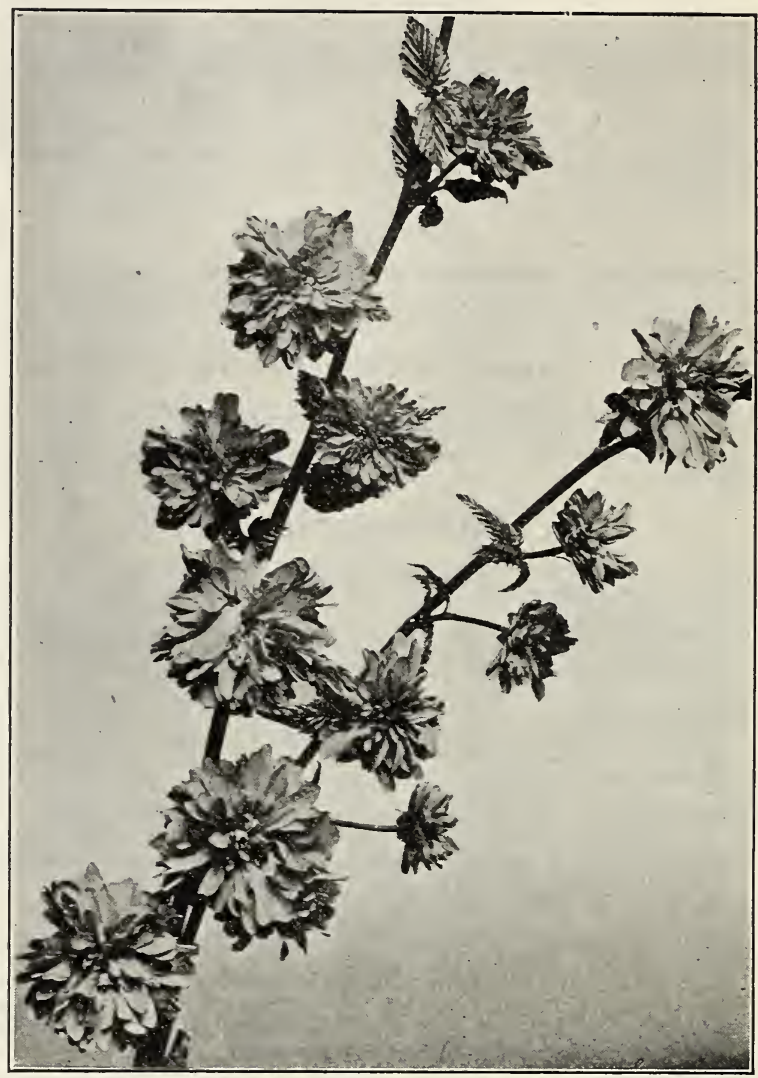

Corchorus or Kerria Japonica

\section{Corchorus or Kerria Japonica}

A graceful shrub of medium height; producing double yellow rose-like flowers an inch across, which appear in April. Bare roots, 2 to 3 feet, well branched. 75 c each.

\section{Cornus (Dogwood)}

AIBA SIBIRICA (Siberian Dogwood)--A medium-sized shrub of erect growth. Branches bright red, particularly conspicuous in Winter. Flowers small, cream colored, in numerous clusters; berries light blue. Bare roots, 2 to 3 feet, $75 \mathrm{c}$ each.

\section{Cranberry Bush (Viburnum Opulus)}

This shrub grows 12 feet tall and belongs to the same family as the Snowball. Blooms in late Spring, followed by bright scarlet berries at the end of July, which remain on the branches until the following Spring. The berries are not eaten by birds. Foliage colors highly in the Fall. Bare roots, 2 to 3 feet, bushy, 75c each.

\section{Crataegus (Washington Thorn)}

CORDATA-One of our handsomest small trees. Leaves are triangular, lobed and deep glossy green until late Fall, when they assume beautiful red and yellow tints. Flowers are white, followed by large clusters of small, glossy, intensely red berries in the late Fall. 8 feet, heavy stock, $\$ 2.00$ each.

\section{Currant, Flowering}

RED FIOWERING-A large native shrub of upright habit with many red-barked twigs. Blossoms rose red in long drooping racemes in early Spring, followed by large glaucous-blue berries. Bare roots, 2 to 3 feet, 60 c. each. 


\section{HaLlawell SEed co. SHRUBS AND TREES SAN FRANCISCO, Calif.}

\section{Deutzia}

Graceful shrubs, with slender branches and effective foliage, blooming in great profusion. The flowers are produced in long racemes, requiring severe pruning immediately after flowering.

CRENATA ROSEA PLENA-A very desirable shrub growing 6 feet high. Flowers double white tinged rose outside. Bare roots 2 to 3 feet, 75 c each.

GRACILIS-A charming dwarf bush, covered with spikes of pure white flowers in early Summer. Bare roots, $1 \frac{1}{2}$ to 2 feet, $75 \mathrm{c}$ each.

IEMOINE-A vigorous growing variety, attaining a height of 3 feet. Flowers pure white; very free flowering. Bare roots, 2 to 3 feet, $75 \mathrm{c}$ each.

DIERVILLA-See Weigelia, page 70 .

\section{Exochorda Grandiflora (Pearl Bush)}

Large shrub blooming early in the Spring when the entire plant is covered with purest white blossoms. The finest white flowering shrub of early Spring. Bare roots, 2 to 3 feet, $75 \mathrm{c}$ each.

\section{Forsythia Suspensa (Golden Bell)}

A Japanese shrub of rather tall growth with slender drooping branches. The golden yellow flowers appear in small clusters along the branches in early Spring. Bare roots, $2 \frac{1}{2}$ to 3 feet, $75 \mathrm{c}$ each.

\section{Hawthorn}

These small trees are well adapted for lawns and for grouping. The small flowers come in clusters and are followed by red berries in the Autumn; a good spreading tree with lustrous green leaves. DOUBIE SCARLET-Bare roots, 6 to $8 \mathrm{feet,} \$ 1.50$ each; $10 \mathrm{feet}$, heavy stems, headed, $\$ 2.50$ each; 10 feet, extra heavy stems, headed, \$3.00 each.

DOUBLE WHITE-Bare roots, 6 to 8 feet, $\$ 1.50$ each.

\section{Hydrangea}

OTAKSA_Very ornamental, large-leared shrubs, with enormous corymbs of beautiful pink flowers. They succeed best in a partially shaded location; very fine for a lawn or for planting in groups. Balled, $50 \mathrm{c}$ each, $75 \mathrm{c}$ each and $\$ 1.00$ each.

PANICULATA GRANDIFLORA-This is one of the finest of all hardy shrubs for the lawn or border. The flowers are white, spike-shaped, and are produced for a long period during Summer and Fall. Bare roots, 2 to $2^{1 / 2}$ feet, $75 \mathrm{c}$ each.

\section{Lilacs (Syringa)}

Beautiful Spring-flowering shrubs; flowers come in large drooping clusters and are very fragrant. Immediately after blooming they should be pruned, as the flowers are always on the old wood. Grafted varieties will usually bloom the first year.

\section{Choice Varieties}

Grafted, bare roots, 3 to 4 feet, $\$ 1.50$ each.

DR. IINDLEY-Brilliant violet-purple, buds red; very beautiful. Single.

EMIL GFNTIL_Large imbricated flowers, bright cobalt-blue, a rare shade. Double.

IA TOUR D'AUVERGNE-Dark lilac. Double.

M A X I M O W I C Z-Violet-heliotrope, reverse silvery; enormous flowers. Double.

NIGRICANS-Lilac, fine. Single.

PERLE VON STUTTGART-Pure white. Single.

ROSEA GRANDIFLORA-Rosy lilac; fine panicles. Double.

\section{Laburnum Vulgare (Golden Chain)}

A beautiful, small-growing tree, with long, drooping racemes of fragrant yellow flowers. 6 to 8 feet. $\$ 1.50$ each.

\section{Lemon Verbena}

This well-known shrub has long, narrow, pointed leaves, which are very fragrant when bruised. $50 \mathrm{c}$ each and $75 \mathrm{c}$ each.

\section{Locust}

Rapid growing tree, with spreading branches, the flowers are in clusters and appear in the Spring.

PINK FLOWERING (Robinia Decaisneana)-Light pink-colored flowers. Bare roots, 8 to 10 feet, $\$ 2.00$ each.

\section{Lonicera (Bush Honeysuckle)}

PINK TARTARIAN-Forms a compact bush about 10 feet tall. Bears small pink flowers of the typical honeysuckle form in May and June, followed by decorative red berries. Bare roots, 2 to 3 feet, $75 \mathrm{c}$ each.

WHITE TARTARIAN-Similar to the above except in color. which is white. Bare roots, 2 to 3 feet, $75 \mathrm{c}$ each.

\section{Maiden Hair Tree}

Also known as the Ginkgo Tree. Foliage is fern-like, resembling a maiden hair fern; clear green during the Summer, changing to a soft yellow in the Fall. Bare roots, 3 to 4 feet, $\$ 1.25$ each.

\section{Mountain Ash, European}

(Rowan Tree)

Flowers creamy-white, foliage somewhat like the Pepper Tree; covered from August to November with large clusters of red berries. Bare roots, 6 to 8 feet, $\$ 1.50$ each.

\section{Peach, Flowering}

An attractive Spring-flowering tree, blooming in April. The branches are covered with a mass of beautiful flowers long before leaves appear.

DOUBLE WHITE, DOUBLE PINK, DOUBIE RED-Bare roots, 4 to 5 feet, $\$ 1.25$ each.

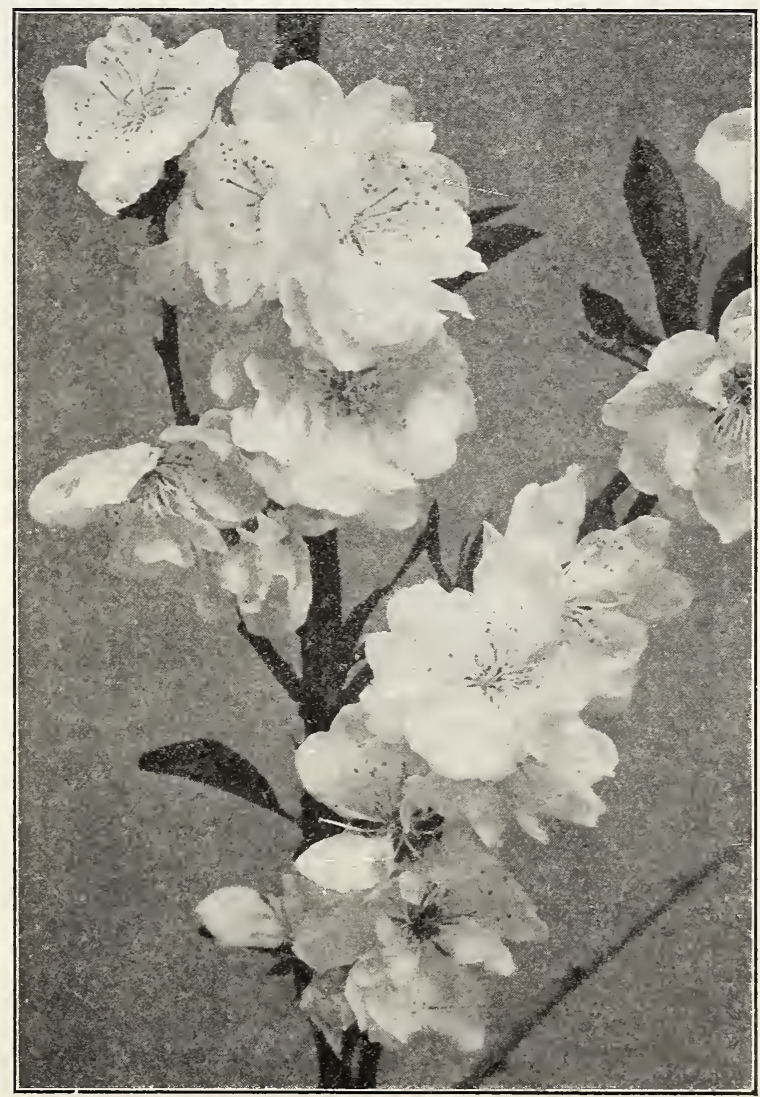

Flowering Peach 


\section{Philadelphus (Mock Orange)}

CORONARIUS - A hardy vigorous growing shrub with handsome foliage and sweet-scented white flowers along the branches. Flowering very profusely in Spring. Immediately after blooming they should be pruned, as the blossoms appear on the wood formed the previous year. 3 feet, bushy, $75 \mathrm{c}$ each.

VIRGINAL - A new variety with flowers that are unusually large, occasionally double crested, with round petals of the purest white. The blooms are in clusters of five to seven and are sweetly scented. Bare roots. 2 to 3 feet, $\$ 1.00$ each.

\section{Plum (Prunus)}

PISSARDI (Purple Leaved Plum) - The young branches are very dark purple; the leaves when young are lustrous crimson, changung to a dark purple, and retain this beautiful tint till they drop late in Autuinn. Very effective when grouped with other trees and shrubs. Bare roots, 5 to 6 feet, $\$ 1.25$ each.

MOSERI-Purple foliage and double pink flowers. Bare roots, 4 to 6 feet, $\$ 1.25$ each.

TRILOBA-A bushy plant with three lobed green leaves; flowers double rosy pink and very numerous, appearing before the leaves and iollowed by small red fruit. Bare roots, 4 to 5 feet, $\$ 1.25$ each.

\section{Pomegranate, Flowering}

DOUBLE RED-A rapid growing shrub with double, deep scarlet flowers. In bloon throughout the summer. Bare roots, 4 feet, $\$ 1.00$ each.

\section{Poplar}

Poplars are very rapid-growing trees and thrive under a great variety of conditions as regards soil, but do best in damp situations. Their leaves are bright and make a fine contrast when grouped with other trees of darker foliage. They are well adapted for wind breaks and are very effective when planted in groups by themselves.

CAROLINA-A very distinct tree, making a large, spreading head. Excellene for avenue planting. Bare roots, 7 to 8 feet, $85 \mathrm{c}$ each; $\$ 8.00$ per 10 .

LOMBARDY-A very rapid, erect-growing tree with a tall spiry form and particularly striking and picturesque when grouped per 10.

\section{Quince (Japanese Scarlet Flowering)}

This is the first shrub to bloom in the Spring, and the bright, scarlet flowers apuea- in zreat proiusion, covering every branch and twig before the leav ; appear; of dwarf habit and well adapted for ingle plants on the lawn or for borders of groups of trees.

Bare roots, grown from cutings, 2 to 3 feet, $\$ 1.00$ each.

ROWAN TREE-See unde- Mountain Ash.

\section{Snowball (Viburnum)}

COMMON-A favorite shrub prodncing immense white ball-shaped flowers in great protu-ion in May and June. Bare roots, bushy, $2 \frac{1}{2}$ to 3 feet, $\$ 1.00$ each.

JAPANESE - Produces large white globular heads, very free bloomer. Bare roots, $2 \frac{1}{2}$ to 3 feet. kushy, \$1.25 each.

\section{Snowberry (Symphoricarpos)}

RACEMOSA-Native shrub of spreading, arching growth, bearing small pink flowers and showy clusters of very large clear white berries at ends of branches. Bare roots, 2 to 3 feet, well branched, $60 \mathrm{c}$ each.

VULGARIS - Red Fruited Snowberry, also known as the Indian Currant. A slender shrub growing 4 feet tall; loaded during the Fall and Winter with small dark red berries in dense clusters. Bare roots, 2 to 3 feet, well branched, $60 \mathrm{c}$ each.

\section{Sycamore, European}

Also known as the Oriental Plane. A handsome, spreading tree with dense, bright green, maple-like foliage. One of the best street trees. Bare roots, 10 feet, $\$ 1.50$ each; 12 feet, $\$ 2.00$ each.

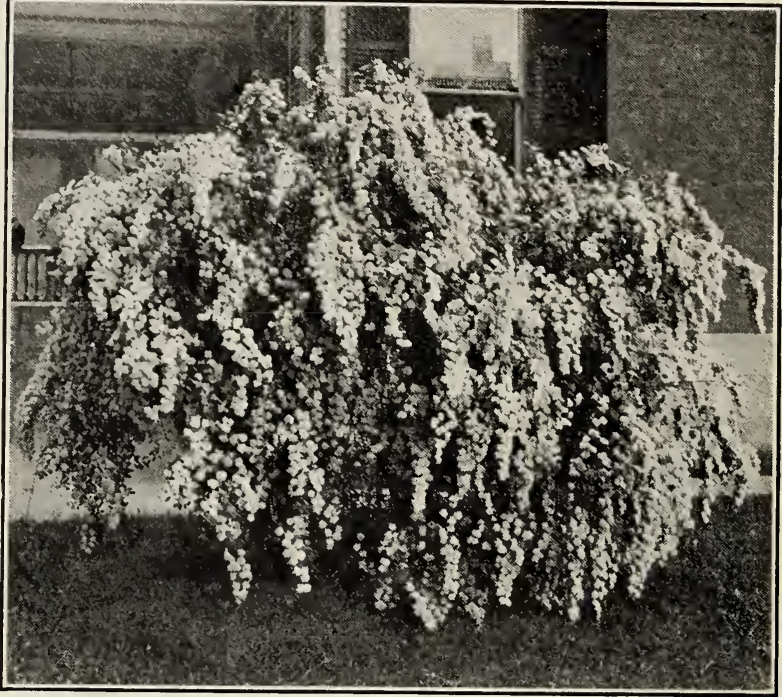

Spiraea Van Houttei

\section{Spiraea}

ANTHONY WATERER-A valuable and distinct variety; color bright crimson: it is of dwarf. dense growth; in bloom the entire Summer and Fall. Bare roots, 2 to 3 feet, bushy, $75 \mathrm{c}$ each.

BIILARDI_Pink flowers in dense spikes; blooms nearly all Summer. Bare roots, 2 to 3 feet, $60 \mathrm{c}$ each; 3 to 4 feet, $75 \mathrm{c}$ each.

VAN HOUTTEI ( $\nabla$ an Houttei's Bridal Wreath)-A beautiful co.npact variety for planting on a lawn or in groups; early flowering and of very graceful habit; clusters of 20 to 30 white florets make up the raceme and are set close along the drooping branches. Bare roots, 2 to 3 feet, $60 \mathrm{c}$ each; 3 to 4 feet, $75 \mathrm{c}$ each.

PRUNIFOIIA (Double Bridal Wreath)-This variety produces prre double white flowers along the entire lengih of the branches. Bare roots, 2 to 3 feet, bushy, $75 \mathrm{c}$ each.

BIUE SPIRAEA-See Caryopteris.

\section{Tamarix}

AFRICANA - A strong, slender, tall-growing, irregular shrub, with feathery foliage and small, delicate flowers, borne profusely on gracefully bending branches. These pink flowers are very attractive during May. Bare roots, 3 to 4 feet, bushy, 75c each. AESTIVALIS-A distinct variety, with delicate, soft, pink sprays of flowers in July and August. Bare roots, 2 to 3 feet, bushy, $75 \mathrm{c}$ each.

\section{Weigelia (Diervilla)}

Ornamental free-flowering shrubs, producing trumpet-shaped flowers of many shades of color during June and July; valuable for planting with other shrubs or as single specimens on a lawn; should be well pruned after flowering in the Summer.

CANDIDA-A free-flowering variety. Fine pure white. Bare roots, $2 \frac{1}{2}$ to 3 feet, bushy, 75 c each.

EVA RATHRE-A remarkably free bloomer, flowering continuously throughout the Summer and Fall; rich ruby-carmine colored flowers, $2 \frac{1}{2}$ to 3 feet, bushy, 75c each.

ROSEA-An elegant shrub, producing trumpet-shaped flowers of a fine roce color. Bare roots, $2 \frac{1}{2}$ to 3 feet, bushy, $75 \mathrm{c}$ each; $\$ 6.50 \mathrm{p} \in ; 10$.

\section{Willow (Salix)}

BABYIONICA (Weeping Willow) -A rapid growing tree with drooping branches, thrives best in a wet place. 6 to 8 feet, $\$ 1.25$ each.

RINGLEAF WILLOW-A rare variety, of weeping habit; leaves are twisted in corkscrew fashion. 6 to 8 feet, $\$ 1.50$ each. 


\section{Climbing and Trailing Plants}

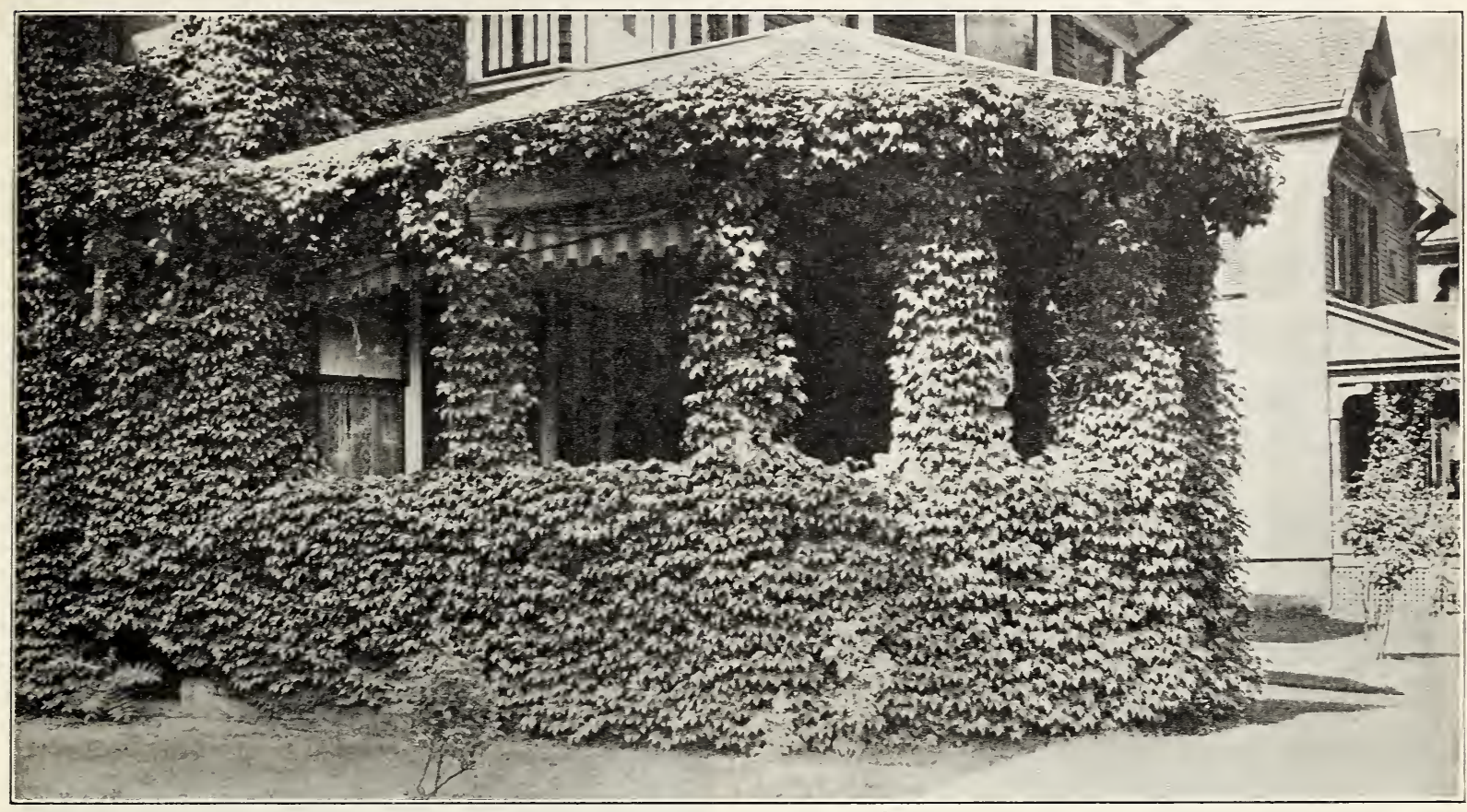

Ampelopsis Veitchii or Boston Ivy

Transportation charges on Vines are to be paid by customer.

Please give name of express and freight offices where they differ from postoffice.

Potted plants are taken from pots when shipped.

\section{Ampelopsis}

VEITCHII (BOSTON IVY)-One of the most ornamental of climbing foliage plants, clinging closely without any assistance to a stone wall or wooden surface. In Autumn the leaves assume a reddish-copper tint and are very effective. 2-year old roots. $50 \mathrm{c}$ each; $\$ 4.50$ per 10 .

QUINQUEFOIIA (VIRGINIA CREEPER) - Foliage much larger than the preceding, with a more vigorous habit of growth, the leaves assuming a bronzy hue in the Fall, but not of clinging habit. $50 \mathrm{c}$ each, $\$ 4.00$ per 10 ; and $60 \mathrm{c}$ each, $\$ 5.00$ per 10 , ac cording to size.

SEMPERVIRENS-An evergreen variety with small, dark green, glossy leaves; has tendrils, but does not cling to a smooth surface. Pot grown. 75c each.

\section{Australian Pea Vine}

A very fast-growing evergreen climber, which we can recommend to those desiring a rapid grower. The flowers are pea-shaped. pink and produced in great abundance. 4 -inch pots. $35 \mathrm{c}$ each; $\$ 3.00$ per 10. (Protect from frost until established.)

\section{Bignonia, Trumpet Vine}

Beautiful climbers with large, showy, trumpet-shaped flowers in various colors, valuable for covering walls or climbing trees; they require a warm, sunny position and should be well protected.

CHERERE-An evergreen variety, with long, trumpet-shaped flowers 3 inches in diameter; in color a rich shade of blood red. 4 inch pots. $60 \mathrm{c}$ each; 5 -inch pots, $75 \mathrm{c}$ each.

GRANDIFIORA-A deciduous rapid growing variety bearing large scarlet trumpet-shaped flowers. Bare roots, $75 \mathrm{c}$ each.

TWEEDIANA-Flowers lemon-yellow and usually broader than long. Evergreen with tendrils that adhere to stone. 5 -inch pots, $75 \mathrm{c}$ each.

\section{Bougainvillea}

(Protect from frost until established)

BRAZIIIENSIS-A beautiful climber, having peculiarly shaped flowers somewhat resembling the leaves in shape and produced along the end of the branches in great profusion; color, rosy purple. They do well in a sheltered sunny location. Strong potgrown plants, $\$ 1.00$ each, $\$ 1.25$ each, $\$ 1.50$ each, and $\$ 2.00$ each. SANDERIANA-Flowers are not so large as the preceding variety, but are produced in greater abundance. Strong pot-grown plants, $\$ 1.00$ each and $\$ 1.25$ each.

CRIMSON IAKE-A new Bougainvillea similar in habit of growth to the other varieties, but entirely different in the color of the lake. Strong pot-grown plants. \$1.50 each and \$2.00 each.

\section{Clematis}

Hardy, vigorous growing deciduous climbers with fine foliage and beautiful flowers of various colors. They do best in a light loamy soil. which should be well drained and which should receive annual applications in Winter of well-decayed manure: in planting, the roots should be well spread out and the plants pruned to one-half their height; they should never be allowed to get very dry.

MONTANA-A rapid grower; the flowers are pure white and about the size of a dollar and are produced in Spring in great profusion. 4-inch pots, $75 \mathrm{c}$ size.

MONTANA RUBENS-Similar in growth and habit to the preceding variety, but flowers are deep pink in bud, lightening to blush as they open. Pot grown. \$1.00 each.

PANICUIATA-A very hardy climber with fragrant small white flowers in clusters, completely covering the upper portion of the vine in late Summer:
3 -year-old roots, 75 c each.

\section{Clianthus Puniceus}

\section{(Protect from frost until established.)}

Excellent for training against a wall. bearing great masses of drooping brilliant scarlet blossoms, which resemble a parrot's bill. Pot grown, 75c each. 


\section{Ficus Repens}

A handsome little evergreen climber with small dark green leaves, which clings to stone or wood. Pot-grown, $50 \mathrm{c}$ each and $75 \mathrm{c}$ each.

\section{Hops (Humulus Lupulus)}

One of the very best climbers for covering unsightly places. It is a rapid grower and bears a profusion of seed pods. $75 \mathrm{c}$ per dozen (postpaid).

\section{Honeysuckle}

HALIEANA, HAIL'S JAPAN HONEYSUCKLE-A strong, vigorous, almost evergreen sort, with pure white flowers, changing to yellow; very fragrant; a long and continuous bloomer. Pot grown, $40 \mathrm{c}$ each, $\$ 3.50$ per $10 ;$ and $50 \mathrm{c}$ each, $\$ 4.50$ per 10, according to size.

CHINESE-Strong grower, new growth is reddish-purple on branches and back of leaves. Flowers white and pink, fragrant. Pot grown, 40c each.

BELGIAN or ENGLISH-Red and yellow flowers, long bloomer, very fragrant. $50 \mathrm{c}$ each and $75 \mathrm{c}$ each.

\section{Ipomoea (Moonvine)}

IEARII-A rapid growing climber with large, dark blue flowers: free bloomer. 4 -inch pots, 35c each.

\section{Ivy (Hedera)}

ENGLISH-A valuable plant for covering walls and climbing trunks of trees and also for covering the ground under trees, with large, thick, shining leathery leaves: rather slow grower. Pot grown, 35c each, $\$ 3.00$ per 10 and 50c each, $\$ 4.50$ per 10, according to size.

DENTATA AUREA-A giant leaved form with a broad yellow margin. 4 -inch pots, $50 \mathrm{c}$ each.

\section{Jasmine}

Very graceful trailing or climbing plants.

GRANDIFLORUM (Catalonian Jasmine)-Flowers pink in bud, white when open, very large and delightfully fragrant. Blooms most of the time. Evergreen, 4 -inch pots, $60 \mathrm{c}$ each; 5 -inch pots, $75 \mathrm{c}$ each.

HUMIIE OR REVOLUTUM (Italian Yellow Jasmine)-A vigorous-growing variety, producing yellow flowers all Summer. Can be grown as a climber or shrub. 4-inch pots, 50c each. 6 -inch pots, $75 \mathrm{c}$ each.

OFFICINALIS (True Jasmine) - Flowers pure white, sweetly scented and produced in clusters in early Spring. 4-inch pots, $40 \mathrm{c}$ each; 5 -inch pots, $60 \mathrm{c}$ each.

PRIMULINUM (Double Yellow Jasmine)-Flowers very large and usually double. The fastest growing jasmine. 4-inch pots, $40 \mathrm{c}$ each; $\$ 3.50$ per $10 ; 5$-inch pots, $60 \mathrm{c}$ each; $\$ 5.50$ per 10 .

\section{Kenilworth Ivy}

A hardy perennial, trailing plant, with small lavender or purple flowers, especiallv adapted for hanging baskets or for trailing over walls. 3 -inch pots. $25 \mathrm{c}$ each; $\$ 2.00$ per 10.

\section{Lantana}

(Protect from frost until established)

A semi-dwarf evergreen climber, bearing verbena-like clusters of flowers in various colors. Should be planted in sunny position. ORANGE-YELLOW-Pot grown, $35 \mathrm{c}$ each and $50 \mathrm{c}$ each. PINK-Pot grown, $35 \mathrm{c}$ each and $50 \mathrm{c}$ each.

\section{Mandevillea Suaveolens}

\author{
(Chile Jasmine)
}

A deciduous vine, bearing white flowers shaped like Jasmine, but far larger and even more fragrant, Remarkable for the long seed pods in pairs, joined at the tips. Summer bloomer. 4-inch pots, $50 \mathrm{c}$ each.

\section{Muehlenbeckia Complexa \\ (New Zealand Mattress Vine)}

This pretty, strong growing climber and trailer is very desirable for covering old stumps of trees, rockwork, etc. The foliage is small, dense, and graceful. 4 -inch pots, $35 \mathrm{c}$ each; $\$ 3.00$ per 10.

\section{Passion Vines (Passiflora or Tacsonia)}

(Protect from frost until established)

Very rapid growing evergreen climbers, with large green leaves and brilliantly colored handsone flowers. Well adapted for covering walls, blooming very freely in the Summer and Fall.

JAMESONI-Bright salmon-pink with a tube four inches long.

Foliage glossy bright green. 5 -inch pots, $75 \mathrm{c}$ each.

PINK-Clear pink flowers. 4-inch pots, $50 \mathrm{c}$ each.

SCARLET-A very brilliant color. 4 -inch pots, $50 \mathrm{c}$ each.

\section{Plumbago Capensis, Blue}

Can be trained as a bush or climber. Flowers light sky-blue, verbena-shaped, produced throughout the entire Summer; stands drought and water and the brightest sunshine. Gallon cans, $75 \mathrm{c}$ each.

\section{Polygonum (Silver Lace Vine)}

AUBERTI-A hardy climber of vigorous growth producing great foamy sprays of white flowers during Summer and Fall. 2year-old roots, $\$ 1.00$ each.

\section{Sollya Heterophylla}

This is known as the Australian Bluebell Creeper and is valuable for covering banks and low fences; the flowers are tube-shaped and a brilliant blue color. A hardy evergreen climber. Strong plants, 6 -inch pots, $75 \mathrm{c}$ each.

\section{Wistaria}

One of the most elegant and rapid-growing of all climbing plants, bearing long grape-like clusters of flowers in early Spring before the leaves appear; attains an immense size, growing at the rate of 15 to 20 feet in a season.

SINENSIS PURPLE-Racemes nearly a foot long and very compact. Flowers are light purple. 2-year-old grafted stock. $\$ 1.50$ each.

SINENSIS WHITE-Variety of the preceding with pure white flowers. 2-year-old grafted, \$1.50.

MULTIJUGA BIUE-Flowers are smaller but the clusters are longer. 2-year-old grafted stock, $\$ 2.00$ each.

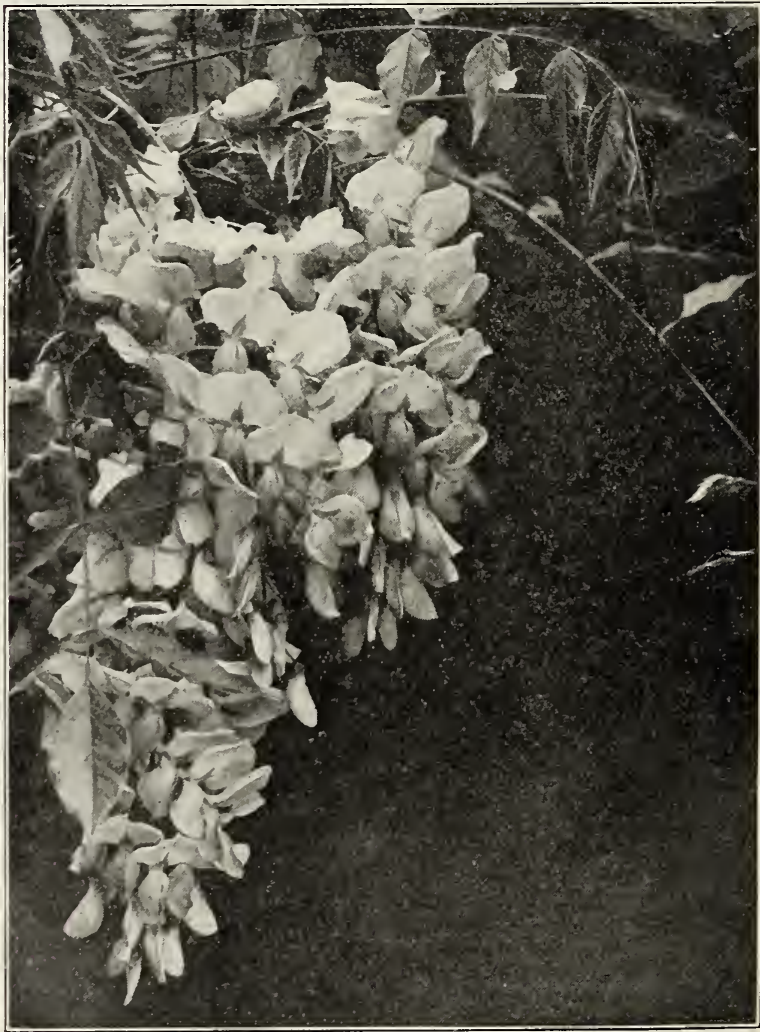

Wistaria 


\section{A H L I A S \\ CULTURAL DIRECTIONS}

Although Dahlias are easily grown in any good garden soil they respond readily to good cultivation. Prepare the soil by digging 12 to 18 inches deep and working in a moderate amount of well rotted manure or commercial fertilizer. Plant the bulbs $21 / 2$ to 3 feet apart at a depth of 5 or 6 inches. Give them just enough water when above ground to keep them growing slowly. Apply fertilizers and water in quantities only after the plant commences to bud. Dahlias may be planted from March to July, preferably in May.

Prices are prepaid anywhere within the third zone.

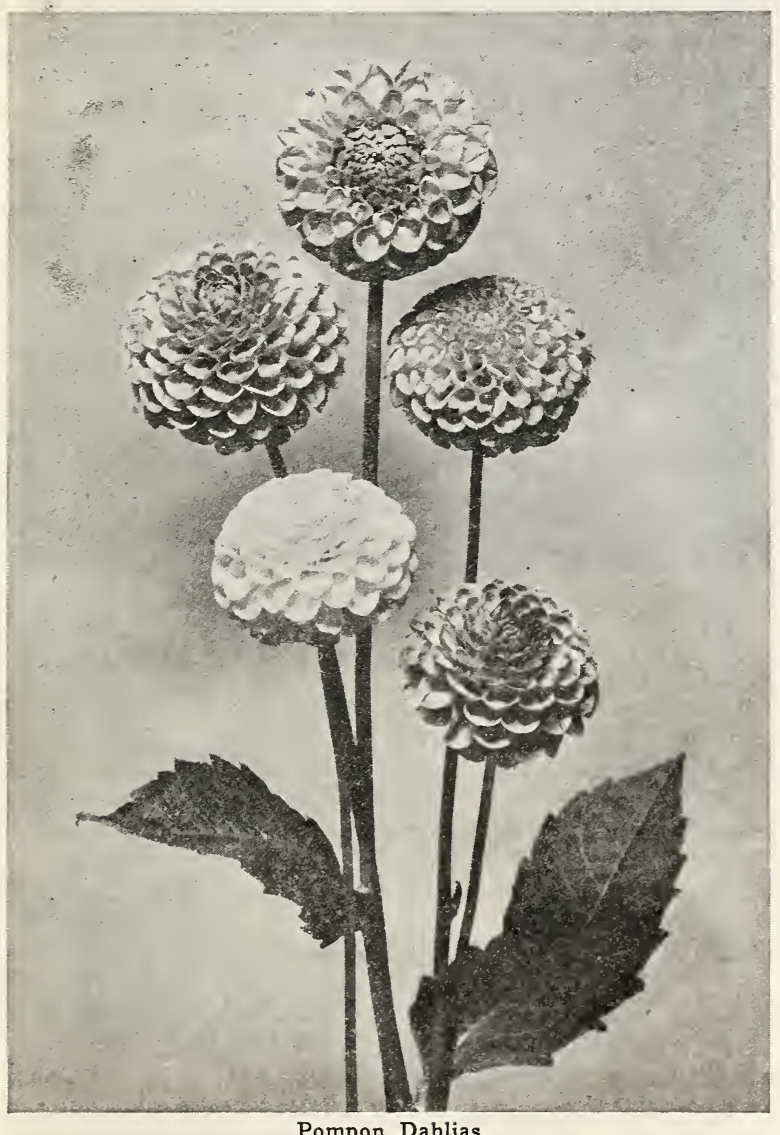

Paeony Flowered Dahlias

Are of immense size, usually one to three rows of long flat or twisted and pointed petals, showing a large open yellow center.

BILLIONAIRE-Beautiful shade of golden-orange; enormous flowers. $75 \mathrm{c}$ each.

CITY OF PORTLAND-Deep clear rich yellow. The blooms are of immense size. Splendid for cutting. $75 \mathrm{c}$ each.

CREAM KING-Beautiful cream overlaid primrose; immense size. $75 c$ each.

GORGEOUS-Yellow shading to scarlet. These blossoms of tremendous size and great depth, stand erect on long stiff stems. $\$ 1.50$ each.

MEYERBEER - Largest paeony dahlia grown; rich purple lined crimson. $75 \mathrm{c}$ each.

MRS. JESSIE SEAL-Old rose shading to pink. The flowers large and full, are produced in great profusion upon extra long, graceful stems. A grand variety. $\$ 1.00$ each.
PEARL RUGGLES-Very large and exquisitely colored, a carmine rose shading to light pink at tips and to white at base of petals. Long wiry stems. $75 \mathrm{c}$ each.

THE ORIOLE-A wonderful blending of burnt orange, red and yellow. Large flowers on long stiff stems. $50 \mathrm{c}$ each.

\section{Pompon Dahlias}

This class produces small double flowers in great profusion. Splendid for cutting, owing to their keeping qualities. They grow about $21 / 2$ feet high and very bushy.

25 c each; $\$ 2.75$ per dozen.

AMBER QUEEN-Deep amber.

ANNIE DONCASTER-Yellow base, suffused pearly pink. CHEERFULNESS-Old gold, tipped crimson.

DAISY-Salmon-rose.

DARK EYE-White with deep lavender center.

EUNICE-White tipped lavender.

JOHNNY-Small deep maroon-crimson.

MARS-Bright scarlet.

NELLIE FRASER-Pretty shade of pink.

ROSEBUD-White edged with rosy pink.

SUNNY DAYBREAK-Yellow tipped red.

SUNSET-Orange, very popular.

35c each; $\$ 3.50$ per dozen.

ELIZABETH-Golden yellow edged brownish-red.

GIRLIE-Pinkish-mauve.

GLOW-Coral-rose.

LITTLE DONALD-Deep red.

PHOEBE-Golden-orange.

TOMMY KEITH_Red tipped white.

50 c each; $\$ 5.00$ per dozen.

AIMEE-Bronze, small blossoms with long stems.

ATOM-Orange, very small, free bloomer.

DEEDEE-Pure lavender, dainty and small.

EILEEN-Lilac.

JOE FETTE-Pure white.

LASSIE-Primrose base, suffused with rose; very good.

LILAC-Dainty golden base, decided pinkish-lilac face; prolific bloomer.

LITTLE BEESWING-Golden yellow, heavily tipped cherry-red; very fine.

LITTLE DAVID-Pure orange, perfect form.

LITTLE DORRIT-Purple, small, perfectly shaped flowers. NEATNESS-Bronzy apricot, light yellow center.

NERISSA-Soft rose tinted with silver.

PHYLLIS-Yellow, heavily shaded cherry-rose; extra good. ROSEA-Deep lilac.

TOM THUMB-Garnet, smallest in cultivation.

YELLOW GEM-A fine yellow sort. 


\section{A H L I A S-Continued}

\section{Decorative Dahlias}

AMUN RA-A decorative of inmense size and a beautiful shade of coppery-orange. The stems are long and stiff and the flowers have splendid keeping qualities. 75c each.

BLACK JACK-Extremely large flowers with long stout stems, of a very rich dark maroon, almost black. $\$ 1.50$ each.

CAROLINE WINTJEN-A beautiful shade of salmon-pink with rose shadings, a very free bloomer with long stiff stems, 50c each.

CHAMPAGNE-Color is a golden champagne with chamois shadings. Immense bloons with good stems. $\$ 1.00$ each.

DELICE-Beautiful glowing rose-pink, fine cut flower. 35 c each.

DR. TEVIS-A beautiful shade of soft salmon-rose, suffused with old gold shading to a golden-apricot center. The immense flowers are held erect on strong, long stems. 50c each.

JANE SELBY-Delicate mauve-pink of immense size, stems long and stiff. Unusually fine for cutting. $75 \mathrm{c}$ each.

KITTY DUNLAP - It is of the delightful shade of the American Beauty rose. The formation of the flower is perfect, with long, stiff stems. $\$ 1.00$ each.

LOGAN'S WHITE-The flowers are large, snow white and perfect. Stems long and rigid. \$1.00 each.

MILLIONAIRE-Immense flowers of unusual depth, fine stems. Color a delicate lavender with a faint pink cast overshading it. $50 \mathrm{c}$ each.

MINNIE BURGLE-Vivid scarlet-crimson of fine form. $35 \mathrm{c}$ each. MRS. CARL SAIBACH - The best lavender-pink; very large flowers on long stiff stems. 50c each.

MRS. I. DE VER WARNER-The color is a very deep orchid, maure-pink. The flowers are large and of perfect form. 50c each.

PRIDE OF CALIFORINIA-This is the best red decorative for all purposes. It has size, stem and splendid keeping qualities when cut. $50 \mathrm{c}$ each.

PRINCESS PAT-Old rose, fine stems. 50c each.

SHUDOW'S LAVENDER - Large silvery lavender flowers held erect on long, strong stems. \$1.00 each.

SUFFRAGETTE_Eright canary-yellow, center petals sometimes tipped white. $\$ 1.00$ each.

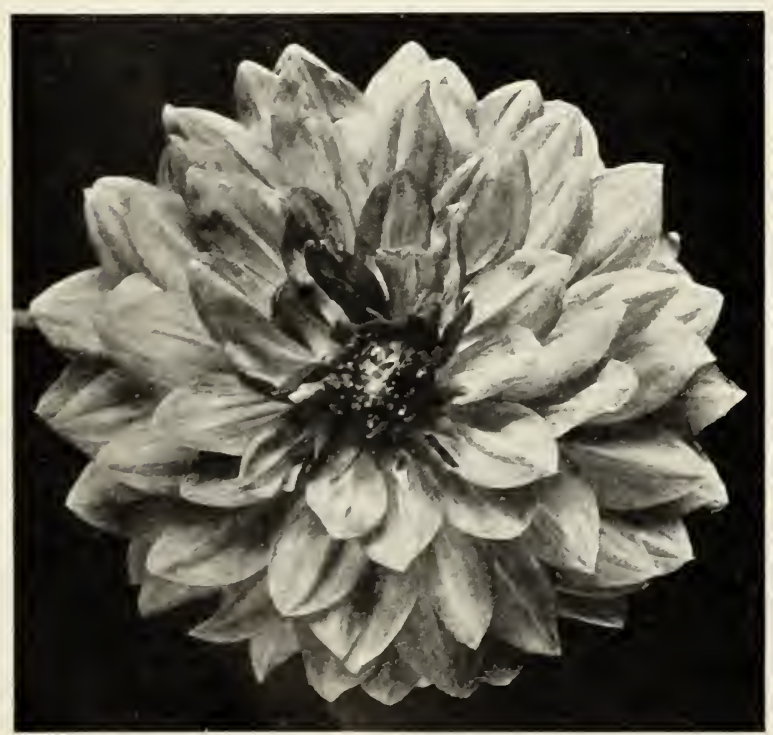

Decorative Dahlia, Amun Ra

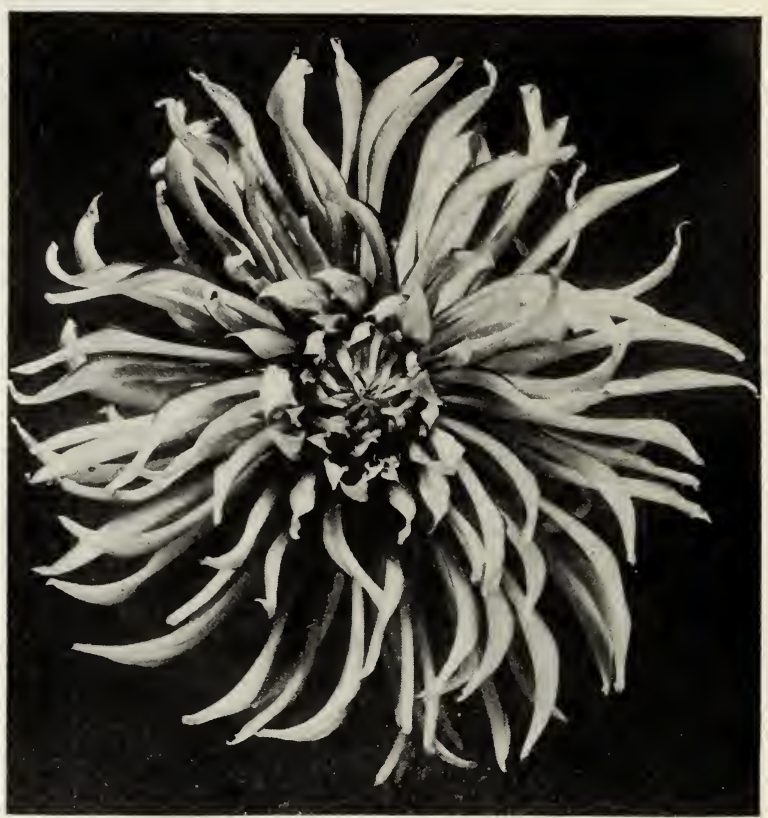

Cactus Dahlia, Ballet Girl

\section{Cactus and Hybrid Cactus Dahlias}

AMBER GLOW-Bright yellow deepening to orange in the center, large flowers and good stems. 75c each.

BALLFT GIRL - Very attractive. Orange, splashed and tipped with white, perfect formation. $\$ 1.00$ each.

CALIFORNIA ENCHANTRESS-An immense bloom of a delightful shade of pale pink. Excellent for cutting. 75c each.

F. W. FELLOWS (C.)-Brilliant orange, very large, fine stem. 75c each.

GEORGE WALTERS (C.)-Salmon-pink and yellow, fine sten. $50 \mathrm{c}$ each.

GOIDEN WEST ( $H$. C.)-Old gold color. Fine stems and good keeping flowers. 50c each.

ISLAM PATROL_Color is an attractive shade of red and gold. Large flowers with good stems. A free bloomer with good keeping qualities. $\$ 1.50$ each.

JEAN CHARZOT (C.)-Golden bronze suffused nasturtium red. $\$ 1.00$ each.

KALIF (C.)-Pure scarlet; a gigantic flower of perfect type, produced freely on strong stout stems. 50c each.

LA FADORITA (H. C.)-Brilliant orange-salmon. 50c each.

MIR. EDNA SPENCER-Lavender or orchid-pink. 50c each.

MRS. W. E. ESTES (C.) - The largest and finest pure white dahlia grown. Held high above foliage on strong stems. A prize winner. 75c each.

TOM LUNDY (H. C.)-Immense blooms of a dark rich crimson; full flowers. $50 \mathrm{c}$ each.

\section{Collections of Dahlias}

6 varieties listed at $50 \mathrm{c}$ each for $\ldots \ldots \ldots \ldots \ldots \ldots 2.75$

12 varieties listed at $50 \mathrm{c}$ each for.......... 5.00

6 varieties listed at $75 \mathrm{c}$ each for........... 4.00

12 varieties listed at $75 \mathrm{c}$ each for. .......... 7.50 


\section{GLADIOLUS}

The bulbs should be planted about 4 inches deep and 7 or 8 inches apart. Any good garden soil will make stron: plants and good bloom, but a light application of any wcil decayed manure or good commercial fertilizer applied on the top of the ground after the plants are sereral inches high will aid in producing larger blooms. Keep the ground moist until the flower spikes begin to appear, then water freely. The bulbs should be taken up in the fall, after the leaves have become rellow, and then stored in a cool, dry place, free from frost. From December to April are the months to plant Gladiolus.

(Postpaid anywhere within the 3rd zone)

Six of a kind at the dozen rate; 50 at the hundred rate.

\section{Select Named Sorts}

ANNA EBERIUS-Dark velvety purple, throat deeper. 10c. each; $\$ 1.00$ per doz.; $\$ 7.50$ per 100 .

CARMEN SYLVA-Pure white except for slight voilet markings deep in the throat. Very fine. $15 \mathrm{c}$. each; $\$ 1.50$ per doz.; $\$ 10.00$ per 100.

CRIMSON GLOW-A brilliant crimson; flowers very large and well placed on a tall spike. $10 \mathrm{c}$, each; $\$ 1.00$ per doz.; $\$ 7.00$ per 100.

DIANA-Clear rich blood-red; grand spike of well placed flowers. 10c. each; $\$ 1.00$ per doz.; $\$ 7.50$ per 100 .

EARIY SUNRISE-Red with salmon-yellow throat; very large. 10c each; $\$ 1.00$ per doz.; $\$ 7$ per 100 .

E. J. SHAYLOR_Large blooms of a beautiful, clear, deep rosepink. 10c each; $\$ 1.00$ per doz.; $\$ 7.00$ per 100 .

FAY IANPHIER - Graceful spikes of coral luster with cerise blending. Flowers of large size and many open at a time. $15 \mathrm{c}$ each; $\$ 1.50$ per doz.; $\$ 10.00$ per 100 .

GOLDEN MEASURE-Beautiful deep yellow, with large ruffled flowers well placed on a tall spike. $15 \mathrm{c}$ each; $\$ 1.50$ per doz.; $\$ 10.00$ per 100 .

HALLEY-Very large flowers of a lovely salmon-pink, lower petals blotched yellow with carmine markings. $7 \mathrm{c}$ each; $75 \mathrm{c}$ per doz.; $\$ 5.00$ per 100 .

HERADA-Blooms of immense size on tall, straight spikes. Color is a pure mauve, with deeper markings in throat; a very attractive color. 8c each; 85c per doz.; $\$ 6.00$ per 100 .

IDA VAN-Flaming orange-red, very rich color. 10c each; $\$ 1.00$ per doz.; $\$ 7.50$ per 100 .

LE MARECHAI FOCH-An improvement on America. A beauti ful soft shade of pink; extra large flowers. $7 \mathrm{c}$ each; $75 \mathrm{c}$ per doz.; $\$ 5.00$ per 100.

LOUISE_Exquisite shade of lilac, growing brighter toward center. $15 \mathrm{c}$ each; $\$ 1.50$ per doz.; $\$ 10.00$ per 100 .

MRS. F. C. PETERS-Beautiful shade of rose-lilac with crimson bordered white on lower segments. Flowers of large size and many open at a time on a strong stem. $15 \mathrm{c}$ each; $\$ 1.50$ per doz.; $\$ 10.00$ per 100 .

MRS. FRANR PENDIETON-A beautiful salmon-pink with a conspicuous blood-red blotch in the throat on the lower petals. Flowers are of the largest size and are borne on strong spikes. 7c each; 75c per doz.; $\$ 5.00$ per 100.

MIRS. WATT-A rich deep cherry-red; very beautiful and quite distinct. $10 \mathrm{c}$ each; $\$ 1.00$ per doz.; $\$ 7.00$ per 100.

ORANGE GIORY - Grand orange colored; very rich and striking color. 15c each; $\$ 1.50$ per doz.; $\$ 10.00$ per 100 .

PANAMA-Large, well expanded flowers of a beautiful deep pink on strong spikes. 10c each; $\$ 1.00$ per doz.; $\$ 7.00$ per 100.

PEACE-A large white sort; interior of petals feathered pale lilac. 10c each; $\$ 1.00$ per doz.; $\$ 7.00$ per 100 .

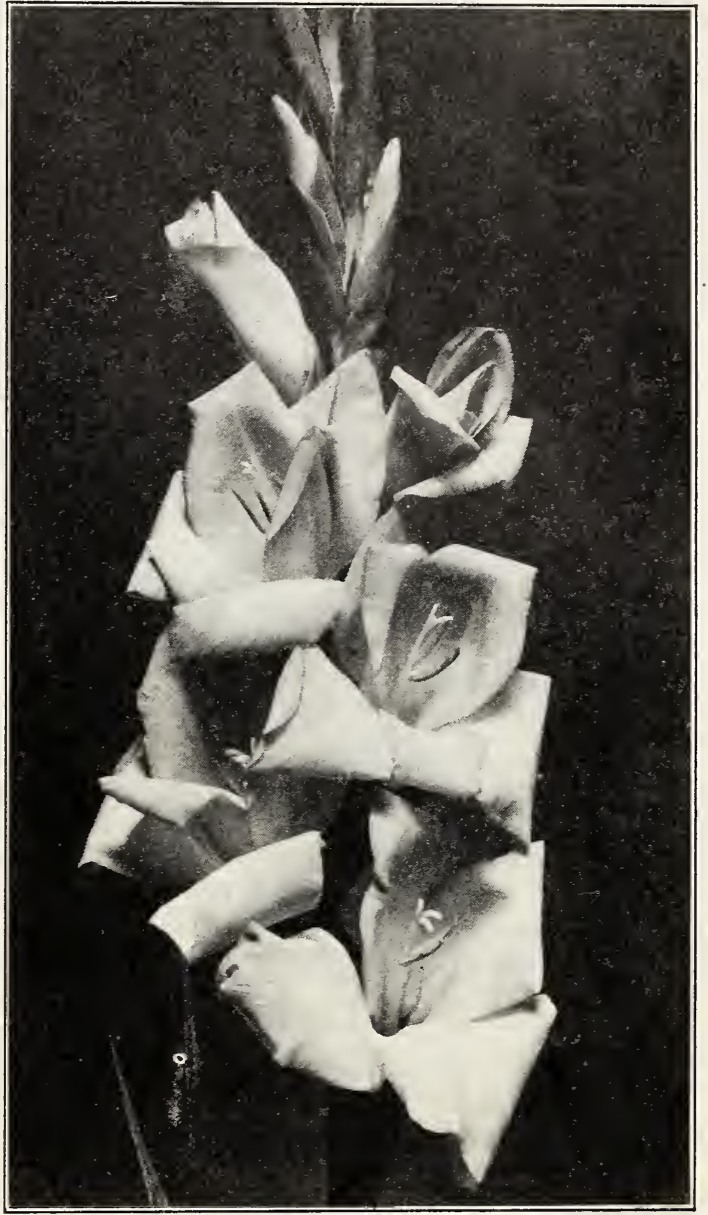

Gladiolus (Prince of Wales)

PINK WONDER-Immense flowers of a lovely La France pink shading to paler pink in the throat. 10c each; $\$ 1.00$ per doz.; $\$ 7.00$ per 100 .

PRINCE OF WALES-Flowers are large and well placed, and the color is a beautiful light salmon. One of the best novelties of recent introduction. $10 \mathrm{c}$ each; $\$ 1.00$ per doz.; $\$ 7.00$ per 100.

ROSE ASH_A beautiful shade of old rose overlaid and blended with pink. 10c each; $\$ 1.00$ per doz.; $\$ 7.00$ per 100.

ROSELIA-Light rose with a large starry white blotch in the throat. A strong spike with several large flowers open at one time. $15 \mathrm{c}$ each; $\$ 1.50$ per doz.; $\$ 10.00$ per 100 .

SCHWABEN-Best clear canary-yellow. The stalks produce about 20 very large flowers -6 to 8 usually open at one time. 7c each; 75c per doz.; $\$ 5.00$ per 100 .

VIRGINIA (Scarlet Princeps)-Large well-formed flowers of a beautiful shade of glowing scarlet on tall spike. 7c each; 75c per doz.; $\$ 5.00$ per 100.

Collection of one of each of the above 25 varieties for $\$ 2.50$.

RAINBOW MIXTURE-A mixture of large flowering gladiolus in a good variety of colors. $50 \mathrm{c}$ per doz.; $\$ 3.50$ per 100 .

EXTRA SELECT MIXTURE-Made up from best named sorts. $\$ 1.00$ per doz.; $\$ 7.00$ per 100 . $\$ 15.00$ for 250 .

For other varieties of Gladiolus, see next page. 


\section{HALLAWELL SEED CO. BULBS AND ROOTS SAN FRANCISCO, CaLIF.}

\section{Choice New Gladiolus}

\section{(Postpaid within 3rd zone.)}

For other varieties of Gladiolus, see preceding page. ALTON-A wonderfully ruffled variety of fine orange color. 20c each; $\$ 2.00$ per doz.; $\$ 14.00$ per 100 .

ARTHUR IOCKWOOD-A very tall variety of clear hermosapink; as many as eight blossoms on a spike open at one time. 20c each; \$2.00 per doz.; \$14.00 per 100 .

CLAREMONT-Beautiful clear, light yellow shading to deep rich vellow in throat; strong flower spike. $20 \mathrm{c}$ each; $\$ 2.00$ per doz.; $\$ 14.00$ per 100.

KIRCHHOFF'S VIOLET-A deep rich violet. 25c each; $\$ 2.50$ per doz.; $\$ 17.50$ per 100 .

MRS. JOHN S. WOOD_One of the largest and tallest gladiolus grown: deep salmon-pink shading to coral-pink, flaked scarlet with ruby dots in throat. $25 \mathrm{c}$ each; $\$ 2.50$ per doz.; $\$ 17.50$ per 100.

NANCY HANKS-Rich apricot to orange-pink with grenadine tongue, vigorous grower. $25 \mathrm{c}$ each; $\$ 2.50$ per doz., $\$ 17.50$ per 100.

Collection of one of each of the above 6 sorts for $\$ 1.25$.

\section{Primulinus Hybrid Gladiolus}

This strain produces beautiful slightly hooded flowers of good size on tall graceful stems, mostly in tones rumnins from light 5ellow to orange-apricot and crimson.

ALICE TIPLADY-Coppery bronze and orange.

AITAIR-Beautiful salmon-saffion.

MING TOY-Buff-yellow; large and showy.

RADIANT-Delicate strawberry-pink, the lower petals soft orangepink.

SALMON BEAUTY-Deep salmon.

SOUVENIR-Amber-yellow; very fine.

Any of the above sorts $10 \mathrm{c}$ each; $\$ 1.00$ per doz.; $\$ 7$ per 100.

PRIMUIINUS HYBRIDS MIXED-An extra choice selection of all colors. $75 \mathrm{c}$ per doz.; $\$ 5.00$ per 100.

\section{MISCELLANEOUS BULBS}

WE GENERAIIY HAVE THE FOLIOWING VARIETIES

IN STOCK FROM DECEMBER TO FEBRUARY

\section{Amaryllis (Hippeastrum)}

VITTATA HYBRIDS-This is pre-eminently a window garden plant producing under simplest conditions, one or two spikes which are crowned with from three to six gigantic blooms, ranging in color from pure white grounds with varied markings of rose or red to self colors as crimson, scarlet, cerise, etc. Cultural leaflet free on request. We can supply large strong bulbs in choicest mixture only. $75 \mathrm{c}$ each, $80 \mathrm{c}$ postpaid; $\$ 7.50$ per doz. postpaid.

\section{Begonia (Tuberous-Rooted)}

Splendid pot plants, also useful for bedding outside in partial shade, flowering very profusely.

We offer Begonias in the following separate color's.

Crimson, Salmon, White, Yellow, Pink and Orange

SINGIE_All colors, separate or mixed. Each, 25c; postpaid, 30c; doz., $\$ 2.50$; postpaid within 3rd zone. 6 at dozen rate.

FRILIED or FRINGED-All colors, separate or mixed. Each, $30 \mathrm{c}$; postpaid 35c; doz., \$3.00; postpaid within 3rd zone. 6 at dozen rate.

DOUBLE-All colors, separate or mixed. Each, 30c; postpaid, 35c ; doz., $\$ 3.00$; postpaid within 3rd zone. 6 at dozen rate.

\section{Yellow Calla Lily (Elliottiana)}

The true yellow-flowered Calla. The flowers are bright yellow and the foliage dark green, spotted white. Large bulbs, each $25 \mathrm{c}$; postpaid, 30c; doz., \$2.50; postpaid within 3rd zone. 6 at dozen rate.

\section{Dielytra or Bleeding Heart}

SPECTABILIS-An old-fashioned favorite; its long racemes of graceful, heart-shaped pink flowers are very attractive. Does well in any part of the hardy border and especially valuable for planting in the shade. Clumps, $\$ 1.00$ each, postpaid.

\section{Gloxinia}

Beautiful pot plants for greenhouse culture. The magnificent tube-shaped flowers measure 3 to 4 inches across. They come in several colors and are very prettily spotted and mottled.

Royal Purple, White edged Pink, Violet edged White, Scarlet, Red edged White. Each, 40c; postpaid, 45c; doz., \$4.00, postpaid within 3rd zone. 6 at dozen rate.

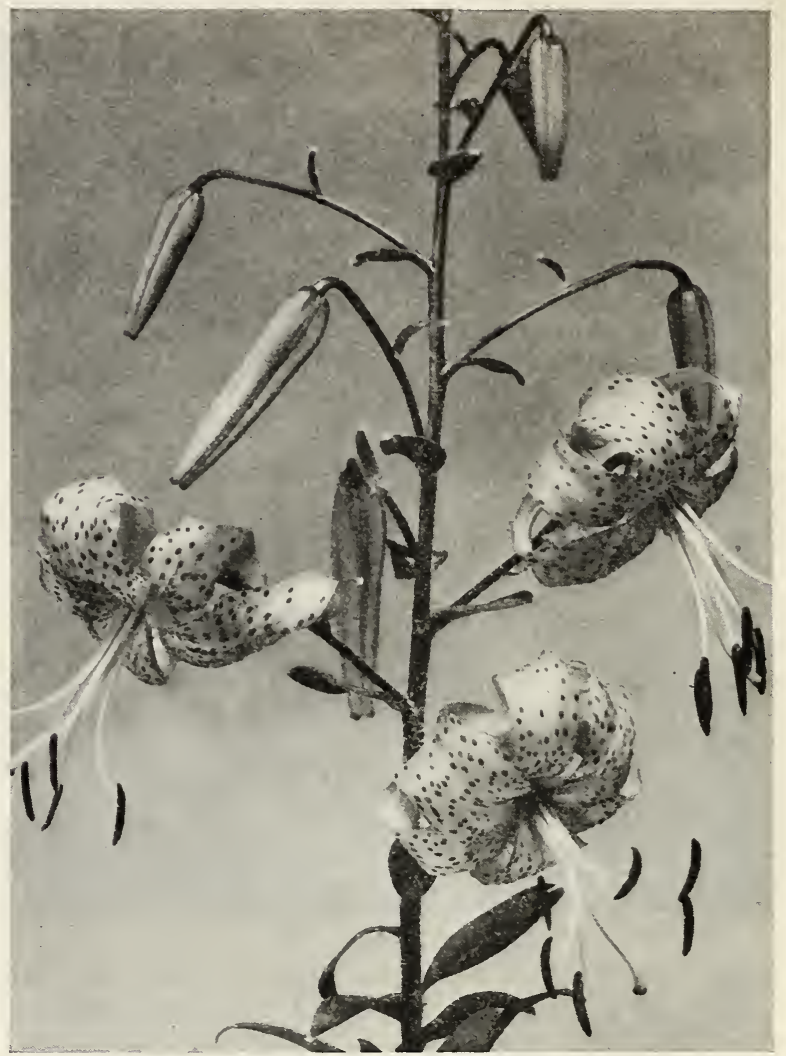

Lilium Tigrinum Giganteum

\section{Lilies}

Lilies succeed best in partial shade and require a loose soil with good drainage. The bulbs of the following varieties should be planted twice their own depth and about one foot apart. Water only lightly until they are well rooted, but liberally when they are about to bloom.

(If wanted by mail within 3rd zone, add postage at rate of $5 \mathrm{c}$ each, 15 c for $6 ; 20$ c per dozen.)

AURATUM-The grandest of all hardy lilies, with large gracefu flowers of a delicate ivory white color thickly studded with chocolate crimson spots, and a bright golden band through the center of each petal. 25c each; $\$ 2.50$ per doz.; larger size, 35c

AURATUM PIATYPHYLIUM_Similar to Auratum, but larger and finer in all respects. Especially noted for its broad, lustrous leaves, which give double attraction. The petals are studded with crimson chocolate spots. $35 \mathrm{c}$ each; $\$ 3.50$ per doz.

HENRYII (The Yellow Speciosum) - The flowers are a rich apricot-yellow with a few brown spots; grows 3 to 5 feet high; very hardy and free flowering. $35 \mathrm{c}$ each; $\$ 3.50$ per doz.

REGALE-A new lily of vigorous growth, 3 to 5 feet high, bearing one to several handsome white fragrant flowers, slightly shaded pink outside and the lower inner surface primrose-yellow; quite hardy. $35 \mathrm{c}$ each; $\$ 3.50$ per doz.; 50 c each; $\$ 5.00$ per doz., according to size.

SPECIOSUM RUBRUM-White, shaded rose and spotted deep red. $25 \mathrm{c}$ each; $\$ 2.50$ per doz.

SPECIOSUM MAGNIFICUM-This variety is similar to the Rub. rum but is a deeper crimson. 25c each; $\$ 2.50$ per doz.

TIGRINUM (TIGER IIIY)-Orange, spotted black. 25c each; $\$ 2.50$ per doz.

\section{Lily-of-the-Valley}

Too well known to require describing. They succeed well in any soil but prefer a shady location. After they are through bloom, care should be taken that they are kept moderately moist.

FINEST SELECTED PIPS-For planting either in pots or out of doors; the finest selected grade. Doz., $75 \mathrm{c}$; postpaid $85 \mathrm{c}$; 100 , $\$ 5.50$ postpaid within 3 rd zone.

\section{Tuberoses}

(Postpaid within 3rd zone; March 15th delivery.)

Plant outdoors when all danger of frost is over. Cover the bulbs

about an inch with fine light soil. doz.; $\$ 7.00$ per 100 . 


\section{Large Flowered Chrysanthemums}

Set out the plants about 2 feet apart in well fertilized ground. After the young plants have grown 12 inches pinch them back about 4 inches, then each plant will send out from 3 to 4 stems. In order to give strength to the blossoms, cover the ground with a layer of an inch or two of decayed manure. As soon as the buds appear on the stems, let the largest remain and pinch off all others.

Ready about May 1. Pot grown. Each 20c; postpaid 30c; doz.,

$\$ 2.00$; prepaid, $\$ 2.25 .6$ at dozen rate.

EARI RITCHENER-Amaranth with a silvery reverse, enormous size.

MAJOR BONNAFFON-Deep yellow, incurved.

MIRS. G. G. MASON-Clear-blood-red.

MRRS. R. C. PULIING-Clear yellow, tremendous size.

PINK TURNER -Clear lavender-pink, incurved.

POCKETT'S CRIMSON-Crimson with a gold reverse.

REFLEXXED LOUISA POCKETT-Reflexed purest white.

SERGEANT WIR. E. YOUNG-Enormous bronze.

VERMONT_One of the very best pinks of enormous size.

WIIIIAM TURNER-Pure white, incurved.

WIM. H. WAITE-Deep bronze, almost shading to scarlet.

YELI.OW TURNER-Light yellow, incurved.

\section{Pompon or Button Chrysanthemums}

Ready about May 1st. Each, 15c; postpaid, 25c; doz., \$1.50; prepaid $\$ 1.75$. 6 at dozen rate.

BALDWIN'S SCARLET-Bronze red, splendid form. Button type. BECKY MCLEAN-Bronzy orange. Baby.

BELLE MAUVE-Rosy mauve. Button.

CHRISTMAS GOID—Golden-yellow. Baby.

INDIAN HIIL_-Orange-yellow. Button.

JUIIA DE WITT-Bright bronzy-amber with deeper shadings. medium.

IITTLE GEM-Clear lilac. Baby.

MRS CHFSTER H. ROBINSON-Deep old-rose color. Medium.

RED CAPRICE-Crimson-maroon. Medium.

ROSE TREVENNA_Light pink. Baby.

WACO-Pure white. Button.

YEILIOW CAPRICE-Brilliant yellow. Button.

\section{Anemone Flowered Chrysanthemums}

An entirely distinct type which is readily identified by the large central cluster composed of a myriad of smaller short petals Ready about May 1st. Pot grown. Each 15c; postpaid, 25c ; doz., $\$ 1.50$; prepaid, $\$ 1.75$. 6 at dozen rate.

CHFSTNUT-An even shade of tan color.

CIFMrNCIA - Deep pink shading to a deeper pink in center cluster.

MrS. O. W. WINSTON-Deep yellow.

RED BIRD-Deep ruby-red with green, golden-crested center.

SURPRISE-Rose-pink.

WEE WAH_Bronzy yellow.

\section{Single Chrysanthemums}

Ready May 1st. Each, 15c; postpaid, 25c; doz., $\$ 1.50$; prepaid, \$1.75. 6 at dozen rate.

BRONZE BUCKINGHAM-Glowing bronze.

CHARLOTTE WAITE-Deep rose-pink.

GEORGE BUCKINGHAM-A grand vigorous pink.

PORTIA_Deep salmon-bronize shading in center to bright flame. RICHARD DELAFIELD-Terra cotta with scarlet shades.

vivian COOK-Yellow.

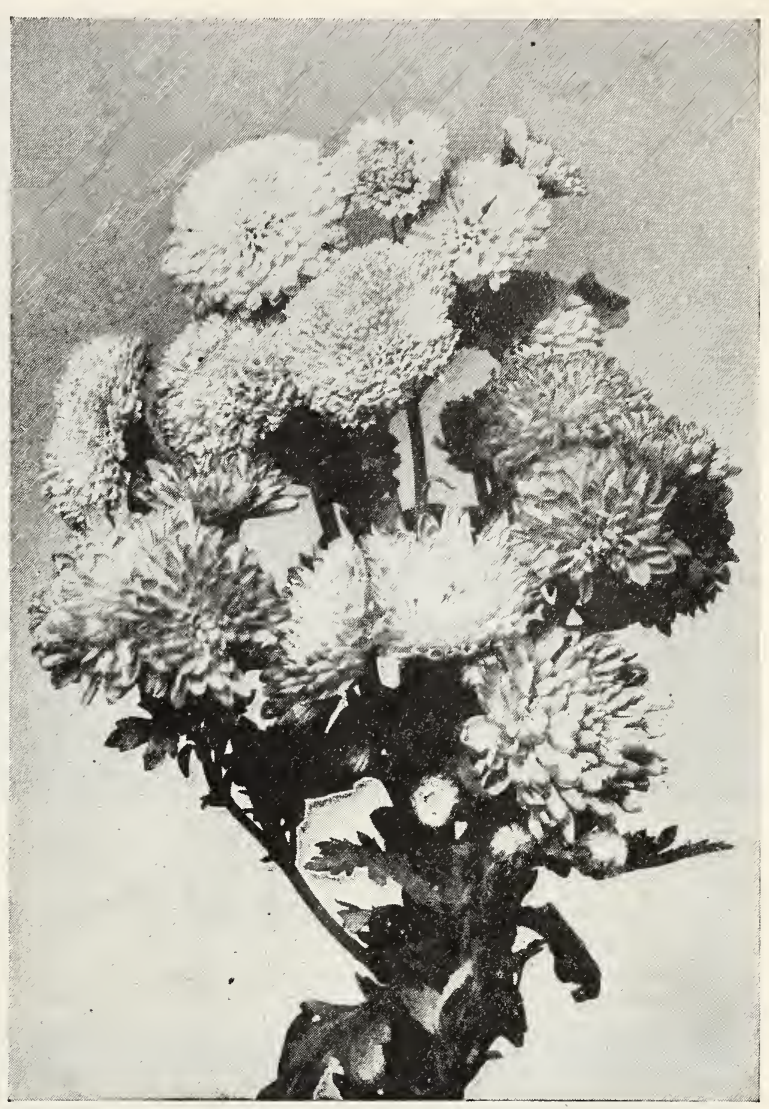

Pompon Chrysanthemums

If Geraniums and Carnations are wanted by parcel post within the 2 nd zone, add $10 \mathrm{c}$ for one plant and $3 \mathrm{c}$ extra for each additional plant to cover postage and packing.

\section{Geraniums}

Price of plants from 3-inch pots, each, 15c; doz., \$1.50. 6 at dozen rate. (Protect from frost until established.)

GERTRUDE PEARSON-Single, clear, rosy-pink with a large white eye.

PAUI CRANDAII_Rich, dark crimson-scarlet. Very large truss. IMRS. E. G. HIII-Beautiful salmon; a fine large flower.

\section{Ivy Leafed Geraniums}

Are indispensable for covering banks, fences, etc. They are almost continuously in bloom, and require very little water. Each, 15c; doz., \$1.50. 6 at dozen rate. (Protect from frost until established.)

SINGIE IAVENDER-A beautiful clear lavender shade. GALIIEE-Double bright pink.

CHAS. TURNER-Double bright salmon-rose, very large.

\section{Carnations}

Ready about April 1st. Pot grown. 6 at dozen rate. DONAID_Large crimson, fragrant. Each, 20c; doz., \$2.00. GOLDEN GLOW-Yellow with red stripe. Each, 25c; doz., \$2.50. IMPROVED WARD-Deep pink. Each, 20c; doz., \$2.00. IADDIF-Warm rose-salmon pink. Each, 25c; doz., \$2.50. MATCHIESS_Pure white. Each, 20c; doz., \$2.00. MORNING GLOW-Light pink. Each, 20c; doz., \$2.00. NORTH STAR-New, clear yellow. Each, 25c; doz., \$2.50. ROYAI_Rich, royal-purple. Each, 20c; doz., \$2.00. SPECTRUM-New scarlet. Each, 20c; doz., \$2.00. 


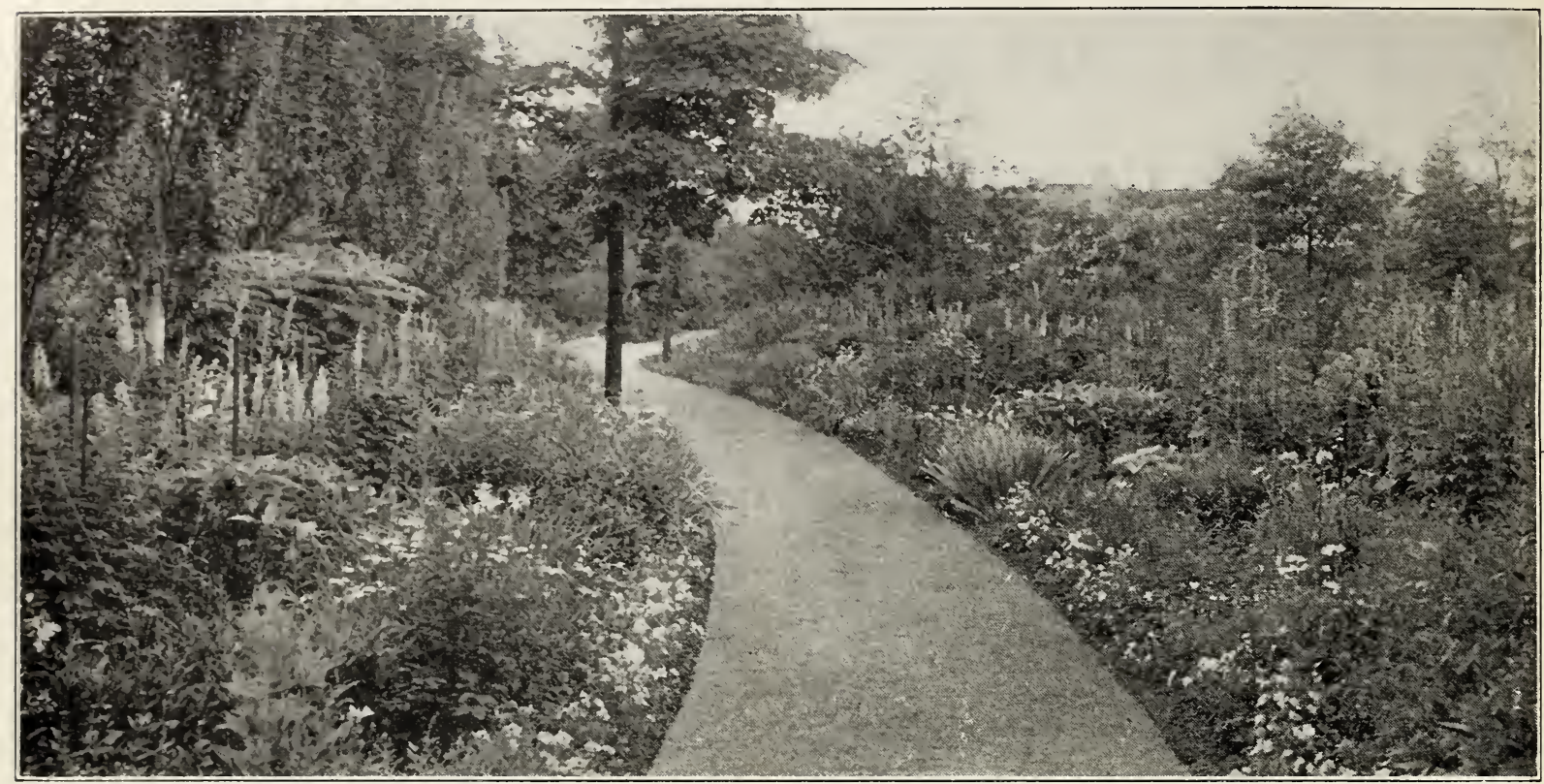

A Perennial Border

\section{Rockery and Perennial Flowering Plants}

If wanted by parcel post within the 2nd zone, add $10 \mathrm{c}$ for one plant and $3 \mathrm{c}$ extra for each additional plant (except where noted) to cover postage and packing. 6 plants of a variety at dozen rate.

\section{Acanthus Mollis}

A handsome foliage plant with very large, dark green and deeply toothed leaves, producing spikes of curious purple and white colored flowers during July and August; fine for lawn groups. 6 -inch pots, each, $75 \mathrm{c}$; postpaid, $90 \mathrm{c}$.

\section{Achillea (Milfoil or Yarrow)}

Plants suitable for dry, sunny places: bloom all summer. FILIPENDULINA-Flat heads of brilliant yellow flowers; finely cut foliage. 4 feet. Strong clumps. 4 -inch pots, each 25c; doz. $\$ 2.50$.

ROSEUM-Flowers pink in dense heads 18 inches high. 4-inch pots, each 25c; doz., $\$ 2.50$

PTARMICA, THE PEARL-The double pure white flowers are

borne in great profusion on strong erect stems. Good cut flower, 2 feet. 4 -inch pots, each 25c; doz., \$2.50.

TOMENTOSA (Woolly Yarrow) - Bright yellow flowers in bloom

from July to September. 6 to 8 inches. Excellent for rockery.

Pot grown, each 25c; doz., \$2.50.

\section{Agapanthus (Blue African Lily)}

The flowers are bright blue and are produced in clusters of 20 to 30 on stalks 3 feet tall. They bloom for a long period in the Summer and Fall.

They will grow in a sunny or partially shaded location. Strong clumps. Each, 35c; doz., \$3.50.

\section{Agathea Coelestis (Blue Marguerite)}

Sky-blue fowers with yellow disc growing 1 foot. Perennial, remaining in bloom all year round. Useful for window boxes. 4 -inch pot, each, 25c; doz., $\$ 2.50$.

\section{Ajuga Reptans Atropurpurea}

A useful plant for rockery and for carpeting the ground particularly in shady positions. Grows 3 to 4 inches high with deep purplish-blue flowers and bronze foliage. Pot grown, each 25c; doz., \$2.50.

\section{Alyssum Saxatile (Golden Tuft)}

An excellent low growing drought-resisting plant for rockwork or the border. Its masses of broad flat heads of bright yellow flowers are produced in May. Its leaves are evergreen and a good ground cover. 4 inch pots, each, $25 \mathrm{c}$; doz., $\$ 2.50$.

\section{Anchusa-Dropmore Variety}

One of the best hardy perennials, growing about 5 feet high. The stems are covered all Summer with numerous wide star flowers of intense blue. Should be in every hardy border. Strong plants, each. $15 \mathrm{c}$; doz., $\$ 1.50$.

\section{Anemone Japonica}

The Japanese Wind-Flowers are amongst the most beautiful of our Fall flowering plants. They bloom in wonderful profusion from August until late in the Fall and attain a height of 4 to 5 feet. They require a partially shaded location; also fine as a cut flower. QUEEN CHARLOTTE-Silvery-pink.

AIBA-Pure white.

RUBRA-Rosy-red.

3 inch pots, each, 25c; doz., $\$ 2.50$.

\section{Aquilegia (Columbine)}

Columbines are among the most beautiful hardy perennials, producing gracefully spurred flowers on stems 2 to 3 feet tall throughout May and June.

LONG SPURRED HYBRIDS-Strong clumps. Each, 25c; doz., $\$ 2.50$.

\section{Arabis Alpina (Rock Cress)}

Similar to the Alyssum or Golden Tuft; but with pure white flowers from early Spring until Summer. 4 inch pots, each, 25c; doz., $\$ 2.50$.

\section{Armeria (Sea Pink)}

Evergreen border plant, very dwarf, requiring no trimming flowers rose-pink. Doz., $35 \mathrm{c}$; postpaid, $45 \mathrm{c}$; 100 , $\$ 2.25$; postpaid $\$ 2.60$. 


\section{hallawell seed co. PERENNIAL PLANTS san Francisco, calif.}

\section{Hardy Asters (Michaelmas Daisies)}

CLIMAX_Extra large violet-blue flowers. Two inches across, four feet tall; very fine.

CORDIFOLIUS-Long, full trusses of small, pale lavender flowers, four feet tall.

II工 FARDEL-Large bright rosy-mauve, four feet tall.

ST. EGWIN-A pleasing soft rosy-pink of medium size; very free flowering of fine compact habit; 2 to 3 feet tall.

SUB-COERULEUS-Forms a dense tuft of leaves, from which issue many leafless stems 12 inches high bearing light blue flowers 3 inches in diameter in great profusion, during June and July. Useful for rockery or edge of hardy border.

4 inch pots, each, 25c; doz., $\$ 2.50$.

\section{Arenaria Caespitosa (Irish Moss)}

Makes a vivid green carpet an inch or so high and spreads rapidly. Fine for rock gardens and flag walks. Sections $25 \mathrm{c}$ each; postpaid, 35c; Flats, $\$ 2.50$ each, express collect.

\section{Aubrietia Graeca}

One of the daintiest of all dwarf creeping plants for carpeting beds or rockwork, forming brilliant sheets of blue for many weeks. 4 inch pots, each, $25 \mathrm{c}$; doz., $\$ 2.50$.

\section{Calceolaria}

(April delivery)

Fine little shrub of low growth, bearing large clusters of pouchlike flowers in yellow and brown shades.

PURE YELLOW or CRIMSON with yellow border. 3 inch pots, each 15c; doz., \$1.50. 4 inch pots, each, 25c; doz., $\$ 2.50$.

\section{Campanula}

CANTERBURY BELLS-Hardy biennials bearing a profusion of bell-shaped flowers. Single pink, white, blue and lavender. Extra large clumps. Each, 15c; doz., \$1.25.

CANTERBURY BELIS-Cup and saucer; pink, white, blue and lavender. Extra large clumps. Each, 15c; doz., \$1.25.

PERSICIFOIIA (Peach Bells) - Perennial; 4 feet tall. In bloom during June and July. Single white and blue. 3 inch pots. Each, 25c; doz., $\$ 2.50$.

PORTENSCHIAGIANA - A low growing perennial sort with slender, graceful foliage and small blue-purple bell-shaped flowers which are produced very freely for a long period. Suitable for rockwork and borders. 3 inch pots. Each, 25c; doz., \$2.50.

CARPATICA (Carpathian Farebell)-A pretty species suitable for rockwork, forming compact tufts not over 9 inches high, flowers clear blue; come well above the foliage on slender wiry stems. Blooms from July until October. Each, 25c; doz. $\$ 2.50$.

PYRAMIDALIS (Chimney Bellflower)-Large flowers on tall spikes 5 to 8 feet high: blooms late. Blue and white. 4 inch pots. Each, 25c; doz., \$2.50.

\section{Giant Flowering Cannas}

All varieties have green foliage unless otherwise specified.

BEACON-Large cardinal-red. 4 feet.

CAIIFORNIA-Orange and pink. 33.4 feet.

HUNGARIA-The best pink Canna. Flowers very large and truses of enormous size. $4 \frac{1}{2}$ feet.

KING HUMBERT-Large orange-scarlet, streaked with crimson. Bronze foliage. 4 feet.

MIMIE. CROZY_Vermilion red with golden yellow border. $31 / 2$ feet. MONT BLANC-Creamy white, $2 \frac{1}{2}$ to 3 feet.

MRS. ALFRED CONARD-Large salmon-pink. 4 feet.

RICHARD WAILACE-Large canary-yellow. 4 feet.

THE PRESIDENT-Rich glowing scarlet with immense rounded flowers. 4 feet.

WINTZRRS COLOSSAI-Immense vivid red. 5 feet.

WYOMING-Large orange coiored flowers; bronze-purple foliage. 6 feet.

YELLOW KING HUMBERT-Deep rich yellow, softly spotted and blotched with bright red. $4 \frac{1}{2}$ feet.

Each, 25c; doz., $\$ 2.50$ postpaid. 6 of any of the above sorts for $\$ 1.25$.

\section{Cerastium (Snow in Summer)}

TOMENTOSUM-A low growing plant, having silvery foliage and producing an abundance of small snow-white flowers. Suitable for rockery or border purposes. Pot grown. Each, 25c; doz., $\$ 2.50$.

\section{Chelone Barbatus Torreyi}

A hardy perennial with long coral-red spikes like a Pentstemon. blooms during July and August. Strong plants. Each, 20c; doz., $\$ 2.00$.

\section{Clivia Miniata}

Also known as Imantophyllum - Very similar to Amaryllis. Leaves are long and strap-shaped, evergreen. The cluster of large showy, orange flowers is borne on a long stalk above the leaves. Each, 50c. Large size, each, $75 \mathrm{c}$

\section{Convolvulus Mauritanicus}

A low-growing plant which spreads about 18 inches and bears for months large and lovely blue flowers in profusion. For covering a dry bank or for a rockery it has no superior. 3 -inch pots. Each, $25 \mathrm{c}$; doz., $\$ 2.50$.

\section{Coreopsis}

A perennial with light, graceful foliage and beautiful golden flowers: blossoms in mid-summer and is one of the best yellow cut flowers.

GRANDIFLORA-Single, yellow, extra large clumps, each 15c; doz., $\$ 1.25$.

GRANDIFLORA FIORA PLENA - New semi-double yellow. Extra large clumps, each $20 \mathrm{c}$; doz., $\$ 2.00$.

\section{Crassula Quadrifida}

A fleshy leaved rock plant with panicles of white flowers, tinged red. Pot grown. Each, 25c; doz., \$2.50.

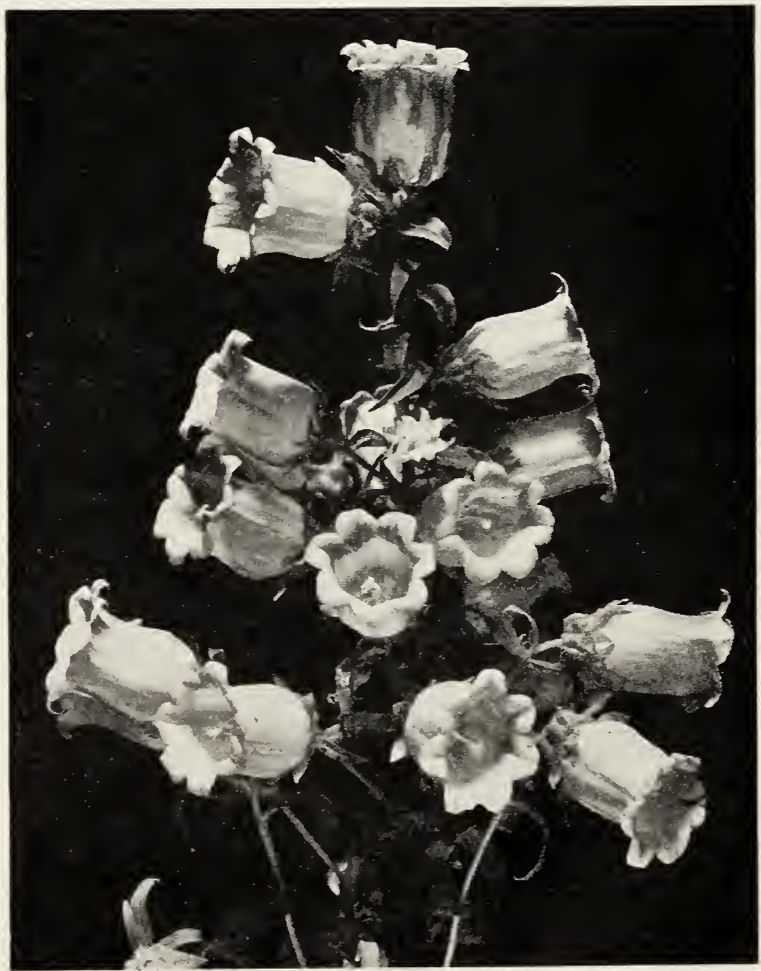

Canterbury Bells, Single 


\section{Dahlia Imperialis-Tree Dahlia}

(April Delivery)

A beautiful flowering plant growing 10 to 18 feet high and covered in the Fall with nodding single dahlia-like flowers of a lavender-pink color; should be left undisturbed in the ground. Strong roots. $\$ 1.00$ each, postpaid.

\section{Dianthus (Hardy Pink)}

CAEsIUS (Cheddar Pink) - A splendid rock plant forming dense tufts of glaucous foliage, 3 to 6 inches high, with fragrant, delicate rose-colored flowers in May and June. Pot grown, each, $25 \mathrm{c}$; doz., $\$ 2.50$.

DELTOIDES (Maiden Pink) - A dwarf little plant with narrow leaves, bearing a profusion of small, fragrant, crimson flowers during June and July. Easily grown in the rockery. Pot grown, each, $25 \mathrm{c}$; doz., $\$ 2.50$.

DELTOIDES ALBUS-A white form of the above variety. Pot grown, each, 25c; doz., $\$ 2.50$.

DELTOIDES BRILIIANT-Glowing crimson; very effective. Pot grown, each, 25c doz., $\$ 2.50$.

PLUMARIUS (Clove Pinks) - The double and semi-double flowers are fringed and fragrant like cloves and come in various colors; extensively used for borders and edgings. Doz., 50c; postpaid, 60c; $100, \$ 3.50$; postpaid, $\$ 3.85$.

\section{Delphinium-Larkspur}

A remarkably showy class of tall growing plants, producing magnificent spikes of blue flowers in Summer; will grow well in partial shade; fine for planting in mixed borders. Improved hybrids. Large 2-year-old clumps. Each, 25c; doz., \$2.50.

BELIADONNA-Light turquoise blue. One-year-old roots. Each, $15 \mathrm{c}$; doz., $\$ 1.50$.

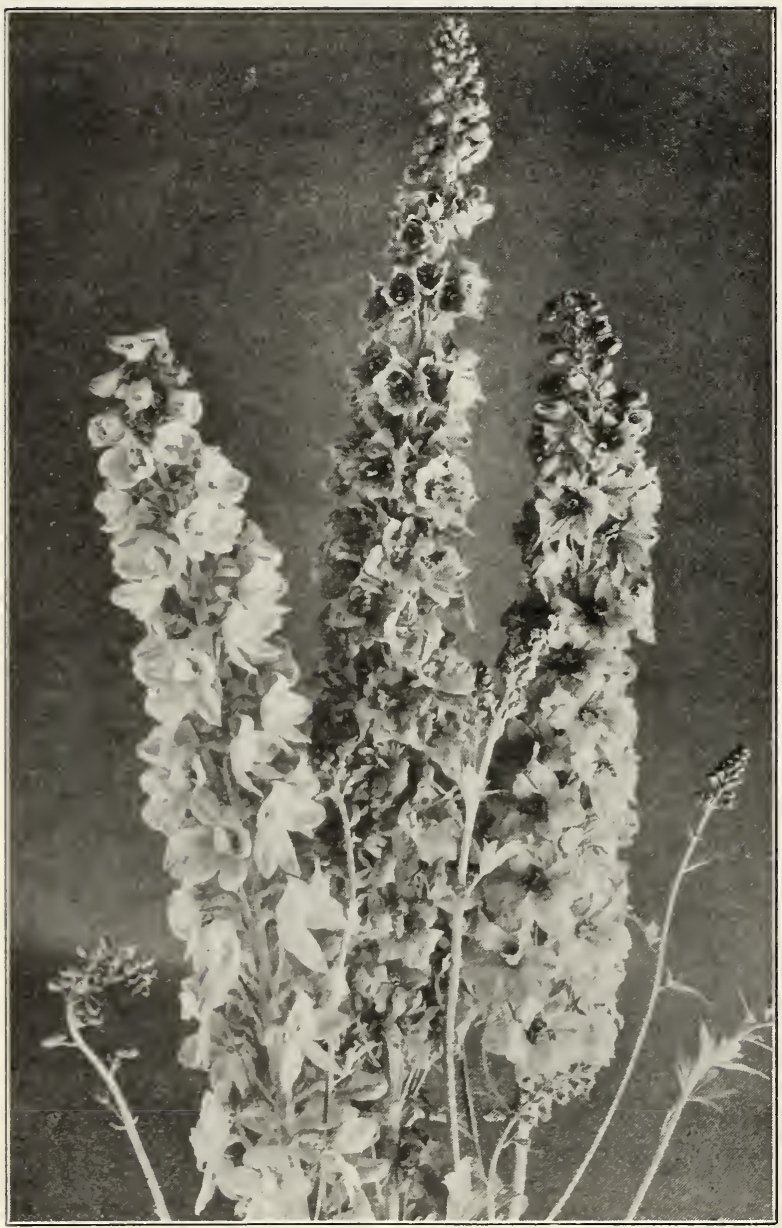

Delphinium Perennial Larkspur
If wanted by parcel post within the 2nd zone, add $10 \mathrm{c}$ for one plant and $3 \mathrm{c}$ extra for each additional plant (except where noted) to cover postage and packing. 6 plants of a variety at dozen rate.

\section{Digitalis (Foxglove)}

Hardy perennials, producing long spikes of finely colored flowers; fine for shrubberies and half shady places. Rose, White and Purple. Extra large clumps. Each, 15c; doz., \$1.25.

YELLOW (Novelty) - Flowers are pure yellow when expanding and change to a primirose color later on; 5 feet. Extra large clumps. Each, 25c; doz., \$2.50.

GIANT SHIRIEY-A new strain. The plants attain a height of 5 to 7 feet, with spikes 3 to 4 feet long carrying flowers of giant size, ranging in color from white to dark rose, which are blotched and spotted. Extra large clumps. Each, 15c; doz., $\$ 1.25$.

\section{Doronicum Excelsum}

A hardy perennial with bright yellow flowers nearly as large as the Shasta Daisy. It blooms very early and for a long season and is invaluable for cutting. The leaves are close to the ground and the slender stems 2 feet or more in height. 4 -inch pots, $25 \mathrm{c}$ each; doz., $\$ 2.50$.

\section{Echium}

FASTUOSUM_An extremely rapid growing shrub with coarse stout branches attaining a height of 6 feet and becoming very bushy. Leaves long, narrow and silky. Flowers clear brilliant blue, in numerous erect spikes, at times almost covering the plant. 6 -inch pots. Each, $\$ 1.00$.

\section{Erigeron}

SPECIOSUM-A Summer flowering border plant with mauve colored single daisy-like flowers, springing from a tuft of leaves, 2 feet tall. 3 -inch pots. Each, 25c; doz., $\$ 2.50$.

MUCRONATUS-Also known as Vittadinia. A charming plant for the garden or rockery, with small daisy-like flowers which are at first rose colored, then white. Blooms profusely almost throughout the entire season. 3 -inch pots. Each, $25 \mathrm{c}$; doz., $\$ 2.50$.

\section{Erinus Alpinus}

Pretty rosettes of foliage and racemes of small rosy-purple flowers. A first rate rock plant and also invaluable for establishing on old walls. Pot grown. Each, 25c; doz., \$2.50.

\section{Francoa Ramosa}

A handsome, half hardy perennial plant which is useful as a decorative pot plant as well as for the perennial border. During the summer months it produces elegant, long sprays of pure white or blush-pink flowers which are excellent for cutting. $2 \frac{1}{2}$ feet high. 4 -inch pots. Each, 25c; doz., \$2.50.

\section{Fuchsia}

These plants require a good rich soil and partial shade. They can be grown as a bush or trained along a fence or side of a house very profuse bloomers.

PHENOMnNAI-Sepals scarlet carmine, corolla $2 \frac{1}{2}$ inches in diameter, rich dark blue, double.

PRINCE CHARMING-Sepals scarlet carmine, corolla rose-red, single. Of dwarf habit, suitable for window boxes.

RFQUA - Sepals white, corolla carmine-rose, single.

STORM KING-Sepals dark carmine, corolla white shaded rose, double.

TORPILEUR - Sepals intense red, corolla flesh, shaded rose, double.

4 -inch pots. Each, 35c; doz., \$3.50. (Protect from frost until established).

\section{Gaillardia}

Very showy hardy perennials growing $1 \frac{1}{2}$ to 2 feet high and blooming all Summer. Flowers are scarlet and yellow, blended and shaded, 3 inches in diameter, produced on long stems.

GRANDIFLOBA HYBRIDS-Extra large clumps. Each, $15 \mathrm{c}$ doz., $\$ 1.25$.

PORTOIA-A superb novelty in this class. The flowers are of enormous size beautifully zoned with golden yellow at the margins of the petals, while the interior is a rich crimson bronze, the stems attaining a length of 2 to 3 feet, each surmounted by a flower of mammoth proportions attaining a diameter of 4 to 5 inches. Splendid for cutting as the flowers last for about a week. 3 -inch pots. Each, 25c; doz., \$2.50. 


\section{hallawell seed co. PERENNIAL PLANTS san francisco, calif.}

\section{Gazania}

Flowers orange or yellow, produced in greatest abundance in the Spring and early Summer, valuable for making borders where there is a lack of water.

SPLENDENS - Orange-yellow. Doz., 50c; postpaid, 60c; $\$ 3.50$ per 100, postpaid.

LONGISCAPA_Golden-yellow, large and beautiful. Also useful for window boxes. Doz., 75c; postpaid, $85 \mathrm{c}$; $100, \$ 5.00$, postpaid.

3 -inch pots. Each, 15c; doz., \$1.50.

\section{Geum}

A showy hardy perennial with large brilliant flowers borne on long stems, blooming nearly all summer, fine for cutting, 2 feet high.

MRS. BRADSHAW-Large double orange-scarlet flowers. Strong plants. Each, 15c; doz., \$1.25.

LADY STRATHEDEN-A grand novelty. Fine rich golden-yellow flowers which match in other respects the popular scarlet variety, Mrs. Bradshaw. Strong plants. Each, 15c; doz., \$1.25.

\section{Gypsophila Repens Rosea}

A trailing plant for the rockery with clouds of small, soft. rose colored flowers in July and August. Pot grown. Each, 25c; doz., \$2.50.

\section{Haworthia Margaritifera}

A succulent rock plant with small leaves which form a somewhat elongated rosette. Pot grown. Each, 35c.

\section{Helenium, Riverton Gem}

A strong growing perennial 3 to 5 feet high, bearing in late Summer and Fall masses of large, daisy-like flowers, which are old gold, changing to wallflower-red as they mature. 4-inch pots. Each, 25 c; doz., $\$ 2.50$.

\section{Helianthemum (Sun Rose)}

Low spreading evergreen plants which for months in the Summer are almost hidden by thin dainty flowers which are usually single and resemble little roses. Excellent for a sunny rockery or in front of the border. They are drought resisting but respond wonderfully to rich soil and care and are lime lovers.

Single Yellow, Pink, Bronze and Double Red-3-inch pots. Each, 25c; doz., $\$ 2.50$.

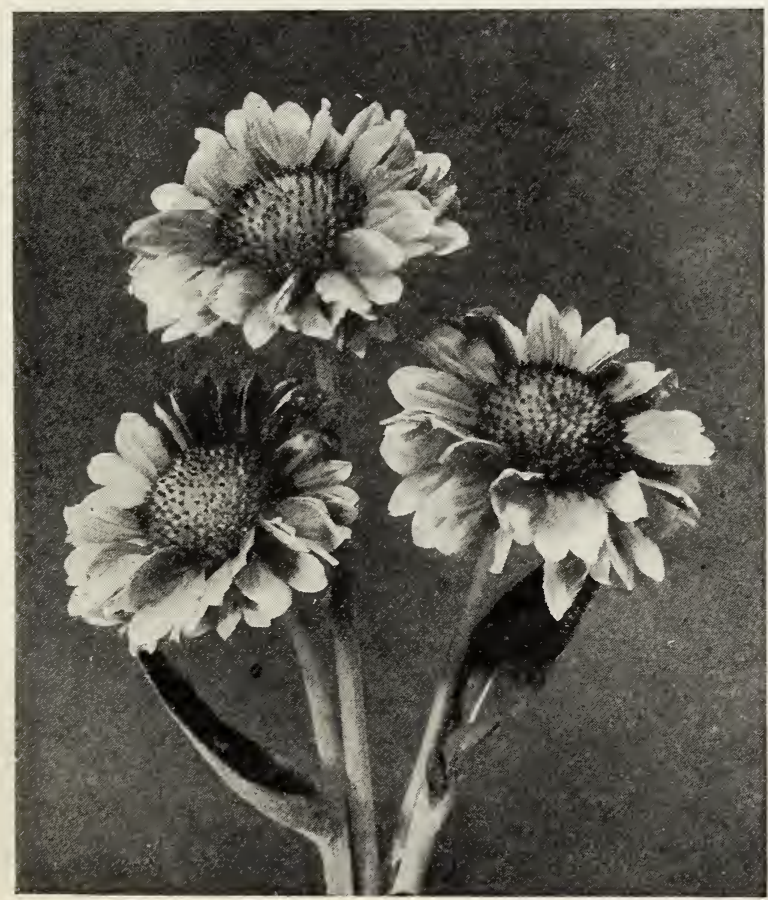

Gaillardia, Portola

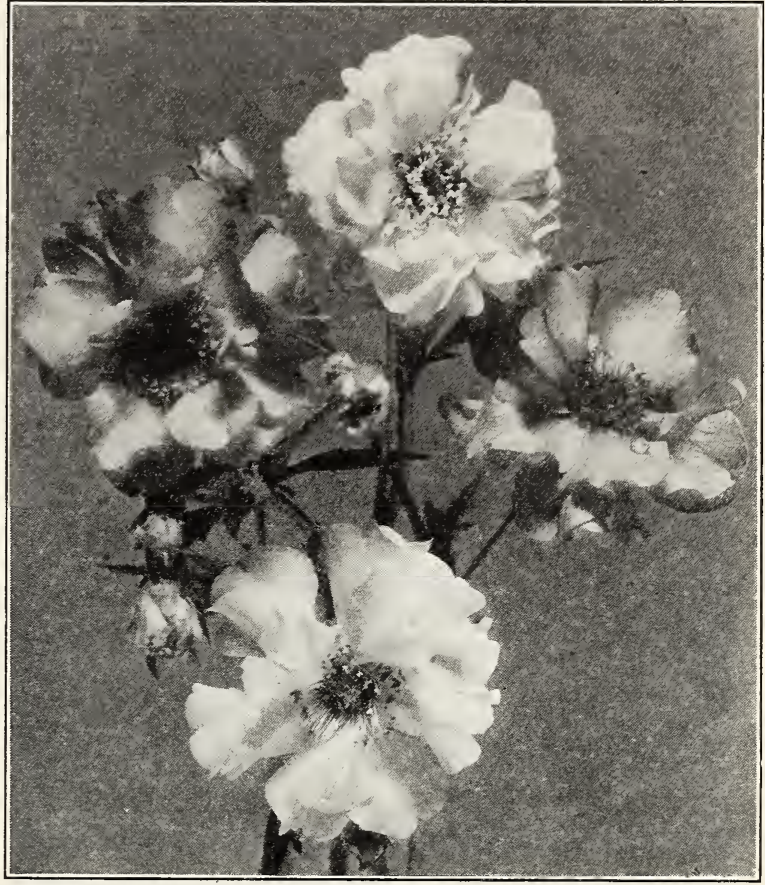

Helianthus (Hardy Sunflower)

MISS MELIISH-A most graceful single-flowered variety, growing from 5 to 7 feet high, continuing in bloom very late in the season. The flowers are produced in long, graceful sprays, which makes it invaluable for cutting purposes. Each, $15 \mathrm{c}$; postpaid; doz., $\$ 1.00$, postpaid.

\section{Heliotrope}

A half-hardy perennial, growing 4 to 8 feet high; small flowers, borne in graceful clusters and very fragrant; forms a large plant and requires a sunny situation: can also be grown against a wall and made to assume the character of a climber.

Light Blue--Pot grown. Each, 35c. Large size, each, 50c. (Protect from frost until established).

Dark Blue-Pot grown. Each, 50c. (Protect from frost until established).

\section{Herbs, Perennial}

Essential for the Kitchen Garden

MINT, ROSEMARY, SAGE, SWEET MARJORAM, THYME and WINTER SA VORY-3-inch pots. Each, 20c.

CATNIP-Pot grown. Each, 25c.

HORSE RADISH-January to May delivery. Roots, doz., 50c, postpaid; $\$ 2.50$ per 100, postpaid.

\section{Heuchera Sanguinea (Coral Bells)}

A low growing plant with heart-shaped leaves which form a low clump 6 to 8 inches high and bearing during July and August: loose graceful sprays of coral-red flowers in great profusion; suitable for the border or rockery and thriving in the shade or in cool places in the sun. 2-year-old clumps. Each, 15c; doz., \$1.50.

\section{Hollyhock}

A hardy perennial of upright growth, 5 to 8 feet high.

Double Rose-pink, Double Red, Double Salmon, Double Yellow, Double Maroon. Strong field grown plants. Each, 15c; doz. $\$ 1.50$.

\section{Hypericum Olympicum}

A trailing species for the rock garden, with slender evergreen foliage and bright yellow flowers. Pot grown. Each, 25c; doz., \$2.50.

If wanted by parcel post within the 2nd zone, add 10c for one plant and $3 \mathrm{c}$ extra for each additional plant (except where noted) to cover postage and packing. 6 plants of a variety at dozen rate. 


\section{HaLlawell seED co. PERENNIAL PLANTS SAN Francisco, CALIF.}

\section{Iberis (Perennial Candytuft)}

A most desirable dwarf plant for the front of the border and one of the best rock plants. The foliage is evergreen and is completely hidden with dense heads of white tinted lilac flowers in early spring; withstands drought. 4-inch pots. Each 25c; doz., \$2.50.

\section{Impatiens Oliveri}

A half hardy showy plant growing 4 to 6 feet high. Flowers pale lilac, $2^{\frac{1}{4}}$ inches across. In bloom for a long time and excellent for (Protect from frost until established).

\section{Lavandula Vera (Sweet Lavender)}

Fragrant blue flowers, from July to September. 4-inch pots. Each, $25 \mathrm{c}$; doz., $\$ 2.50$.

\section{Leucophyta Brownii}

A much-branched rigid little white-woolly shrub, about 1 foot high. Suitable for rock work. Pot grown. Each 25c; doz., $\$ 2.50$.

\section{Linum (Flax)}

PERENNE-An excellent plant for the border or rockery, growing $1 \frac{1}{2}$ feet high with light, graceful foliage. For a long period beautiful blue flowers appear daily in the morning. 3 -inch pots. Each, 25c; doz., \$2.50.

\section{Lippia Repens}

Used in place of grass for lawns. It does not require much water and makes a fairly good substitute. Good roots, $\$ 1.50$ per 100 postpaid.

\section{Lobelia Cardinalis}

A most brilliant colored hardy perennial, succeeding best in a moist, deep loam. The rich, fiery cardinal flowers are produced on pikes often 24 to 30 inches high. In bloom from early in August to late in September. 3 -inch pots. Each, 25c; doz., \$2.50.

\section{Lotus Peliorhyncus}

A trailing plant with feathery leaves of a silvery hue, producing crimson, wing-shaped flowers in loose clusters; useful for hanging baskets or window boxes. Pot grown. Each $35 \mathrm{c}$ and $50 \mathrm{c}$, according to size. (Protect from frost until established).

\section{Lychnis (Campion)}

ALPINA-A very dwarf plant for the rockery. Produces clusters of rose-pink flowers in Spring and early Summer, 4 to 6 inches high. Pot grown. Each, 25c; doz., \$2.50.

CFAICEDONICA-Heads of vivid scarlet flowers blooming a long tinle. One of the brightest plants in the hardy border 3 feet high. Pot grown. Each, 25c; doz., \$2.50.

\section{Lythrum Roseum Superbum}

A strong growing plant, 3 to 4 feet high, thriving in almost any position, producing large spikes of rose colored flowers from July to September. Clumps. Each, 25c; doz., \$2.50.

\section{Marguerite}

(Protect from frost until established).

Hardy perennial shrub, remaining in bloom all year round and requiring very little water.

White or Yellow-3-inch pots, Each, 15c; doz \$1.50. 4-inch pot Each, 25c; doz., $\$ 2.50$.

MIRS. P. SANDERS - Large double white. 3-inch pots. Each, $15 \mathrm{c}$; doz., \$1.50. 4-inch pots. Each, 25c; doz., $\$ 2.50$.

\section{Mesembryanthemum (Ice Plant)}

(Protect from frost until established)

These are much used for planting on banks and hillsides where there is a scarcity of water. They make a gorgeous sight when FIORIBUNDUM-Small lavender-pink flowers with very narrow foliage. Doz., 35c; postpaid, 45c; $100, \$ 2.50$, postpaid.

SPECTABILE - Large bright rose colored flowers with coarse foliage. Doz., 50c; postpaid, $60 \mathrm{c} ; 100, \$ 3.50$, postpaid.

BROWNII-A narrow leaved variety growing 1 foot high or more, and much branched. flowers orange changing to various shades of rose, with petals $3 / 4$ inch long. Suitable for the rock garden and dry situations. Pot grown. Each, 25c; doz., \$2.50.

LEHMANNII_A variety suitable for the rock garden, with small grayish, inflated, three cornered leaves. Pot grown. Each 25c; doz., $\$ 2.50$.

MURICATUM-The small triangular leaves are toothed and very glaucous, giving the plant a bluish effect. Desirable for the rockery. Pot grown. Each, 25c; doz., \$2.50.

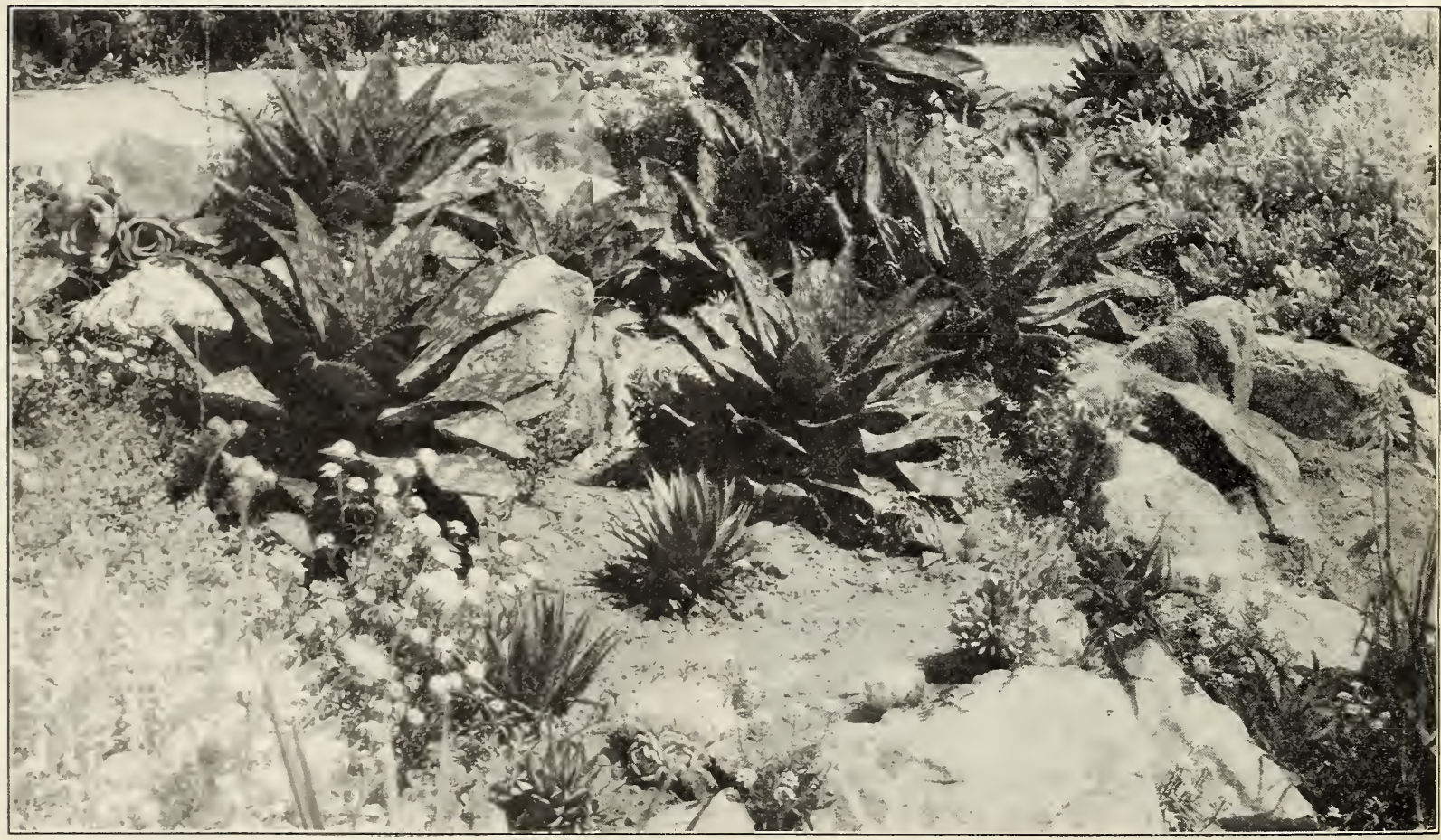




\section{hallawell seed co. PERENNIAL PLANTS san francisco, calif.}

If wanted by parcel post within the 2nd zone, add 10c for one plant and $3 \mathrm{c}$ extra for each additional plant (except where noted) to cover postage and packing. 6 plants of a variety at dozen rate.

\section{Nepeta Mussinii}

A hardy dwarf compact perennial, producing clouds of light blue flowers from May to September. Makes a fine permanent edging and an excellent rock plant; 10 inches high when in bloom. 3-inch pots. Each, 25c; doz., $\$ 2.50$.

\section{Oenothera (Evening Primrose)}

LAMARCKIANA-A tall, strong and much branched sort, with large yellow flowers 3 to 4 inches in diameter. Flowers produced in great freedom from June until October. Requires a sunny situation. 4 -inch pots. Each, 25c; doz., \$2.50.

MISSOURIENSIS-A low species with prostrate or ascending branches. Solitary yellow flowers often 5 inches across. Blooms profusely from June to August; 10 inches high. Good for rock garden or border. Pot grown. Each, 25c, doz., \$2.50.

\section{Pansies (Hallawell's Prize Strain)}

Doz., 35c; postpaid, 45c; 100, $\$ 2.25$ postpaid (out of flats). Large plants in bloom ready in February, doz., 50c; postpaid, $65 \mathrm{c}$; $100, \$ 4.00$, express, collect.

\section{Pentstemon}

A hardy perennial growing 2 feet high, sending up spikes of bright colored and spotted flowers. Somewhat like the Foxglove but in a great variety of colors.

Lavender, Deep Coral-Red and Pink--Field grown plants. Each, $15 \mathrm{c}$; doz., $\$ 1.50$.

Mixed Colors-Field grown plants. Each, 15c; doz., \$1.50.

\section{Perennial Hardy Phlox}

A beautiful and easily grown perennial about 3 feet high, bearing clusters of bright-colored phlox-like blossoms. They remain in bloom all Summer; set the plants 18 inches apart.

LOTHAIR_Salmon-red with dark carmine eye, strong grower.

MRS. CHARLES DOOR-A beautiful shade of lavender.

MIRS. JENKINS_-The best all-round pure white.

PANTHEON-Clear deep pink with faint center.

RIJNSTROOM_Immense flowers and trusses of a beautiful clear pink. Extra fine.

THOR-Deep salmon-pink.

Any of the above in separate colors or assorted in strong plants. Each, 25c; doz., $\$ 2.50$.

\section{Phlox Subulata (Moss Pink)}

A Spring flowering type with pretty moss-like, evergreen foliage which during the flowering season (April and May) is hidden under masses of bloom. An excellent plant for the rockery. Light Lilac, White and Pink. Pot grown. Each, 25c; doz., \$2.50.

\section{Physostegia (False Dragon Head)}

VIRGINICA-Dense bushes about 2 feet high with spikes of delicate lilac pink tubular-flowers. 3 -inch pots. Each, 25c; doz., $\$ 2.50$.

VIRGINICA ALBA - Large, white flowers, much esteemed for cutting. 3-inch pots. Each, 25c; doz., \$2.50.

\section{Plumbago Larpentae}

An excellent rock plant for fall bloom. Flowers intense deep Plumbago-blue. Thrives in sun or light shade. 4 -inch pots. Each, 35c. (Protect from frost until established).

\section{Potentilla, Miss Willmott}

A hardy perennial border plant with handsome, strawberry-like foliage. Flowers are bright cerise and come for a long time. Related to Geum. 18 inches high. Pot grown. Each, 25c; doz., \$2.50.

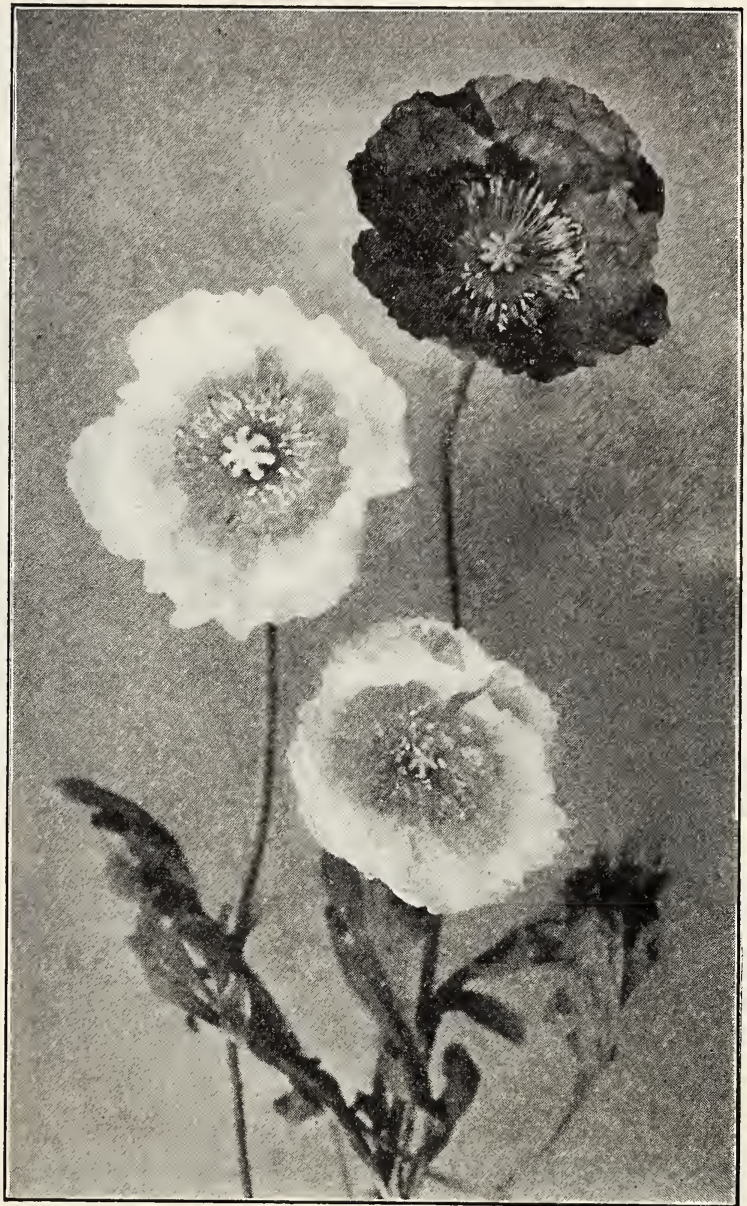

Iceland Poppies

\section{Iceland Poppies}

The plant is of neat habit, forming a tuft of bright green fernlike foliage, from which spring, throughout the, entire season, a profusion of beautiful cup-shaped flowers on slender leafless stems 1 foot high.

Yellow and Orange-Scarlet. 3-inch pots. Each, 15c; doz., \$1.50.

\section{Oriental Poppies}

A charming Summer-flowering hardy plant, producing numerous leafy stems about $2 \frac{1}{2}$ feet high, with large, showy flowers, having: a conspicuous black blotch on each petal.

Red, Salmon Pink, Orange or Mixed Colors. 3-inch pots. Each, $15 \mathrm{c}$; doz., $\$ 1.50$.

\section{Primrose (Primula)}

POLYANTHUS VERIS-A hardy variety used for borders and blooming very early in the year. Mixed colors. Doz., 50c; postpaid, 60c; $100, \$ 3.50$; postpaid, $\$ 4.00$.

AURICULA-One of the treasures of the rock garden. The growth is very attractive, forming rosettes of thick leaves. The flower stalks rise to a height of six or eight inches, bearing heads of bloom of various colors; fragrant. Pot grown. Each, 25c; doz., $\$ 2.50$.

\section{Pyrethrum Hybridum Grandiflorum}

SINGIE MrXEn-A hardy perennial with giant single daisy-like flowers appearing in June and continuing throughout the Sunnmer. The foliage is low and fern-like, and the flowers are on long slender stems.

Field grown plants. Each, 15c; doz., \$1.50.

Extra strong plants. Each, 25c; doz., \$2.50. 


\section{Rehmannia Angulata}

A half-hardy herbaceous perennial with beautiful large rosy-purple gloxinia-like flowers. Suitable for pot culture or outdoors in a sheltered situation. 3 feet tall. 3 -inch pots. Each, 25c; doz., \$2.50.

\section{Romneya (Cal. Tree Poppy)}

COUITERI-Also known as Matilija Poppy. A beautiful half shrubby hardy perennial, growing 5 to 6 feet high. The flowers are pure white with yellow stamens. 5 to 6 inches across, generally 10 to 15 flowers on a shoot. 4-inch pots. Each, \$1.00. 6-inch pots. Each, \$1.50.

\section{Rudbeckia (Cone Flower)}

LACINIATA FL. PL. (Golden Glow)-Handsome perennials, 6 to 8 feet high, covered with very double golden yellow flowers in Summer time. Clumps. Each, 15c; doz., \$1.50.

PURPUREA GRANDIflora (Purple Cone Flower) -Large handsome crimson purple flowers with dark central disc. 3 feet tall. 3 -inch pots. Each, 25c; doz., $\$ 2.50$.

\section{Salvia}

AZUREA-A hardy perennial variety growing 3 to 4 feet high and producing during late Summer, panicles of pretty skyblue flowers in great profusion. It requires a sunny situation and will stand considerable drought. 3 -inch pots. Each, 25c; doz., $\$ 2.50$.

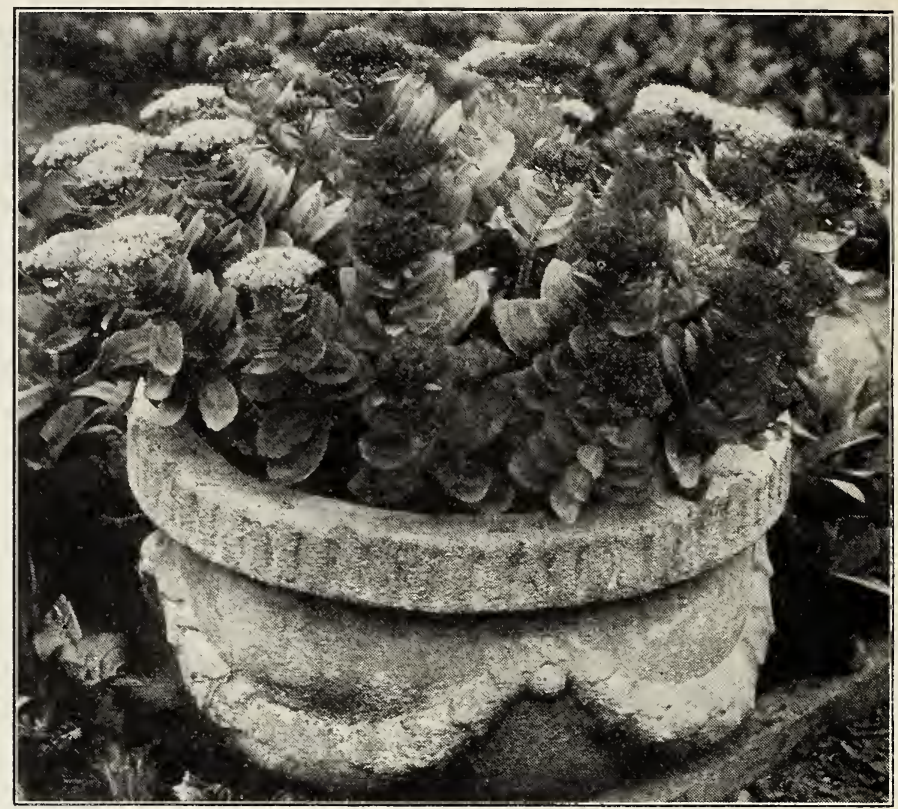

PITCHERI_Same as the preceding variety, except in color, which is intense gentian-blue (deep blue). One of the best late fall flowers. 4-inch pots. Each, 35c; doz., $\$ 3.50$.

IEUCANTHA-A shrubby variety $1 \frac{1}{2}$ to 2 feet high with elong. ated woolly branches. The violet-purple flowers are tipped white and are borne in whorls on spikes which are 6 to 10 inches long. Blooms in late Summer. 3 -inch pots. Each, 25c; doz., \$2.50. 4-inch pots. Each, 35c; doz., \$3.50.

PATENS (Blue Sage)-A tender tuberous rooted plant for the border, two feet high. Flowers are of a rich blue color. The tubers should be lifted in the late Fall and kept in a protected place during Winter. 4-inch pots. Each, $25 \mathrm{c}$; doz., \$2.50. (Protect from frost until established).

\section{Saponaria (Soapwort)}

OCYMOIDES-A dwarf trailing rock plant with small bright rosecolored flowers. In bloom May and June. Pot grown. Each, $25 \mathrm{c}$; doz., $\$ 2.50$.

\section{Saxifraga}

CRASSIFOLIA-A low-growing hardy plant with large leaves, especially adapted for shady places. Bears good-sized pink flowers in a large panicle rising to a foot above the ground. Commences to bloom in the Fall and continues through the Winter. 4-inch pots. Each, 30c; doz., \$3.00.

DECIPIENS (Mossy Saxifrage)-A dwarf variety about 3 inches high, adapted for rock work, making a dense moss-like mat. Flowers white. Pot grown. Each, 25c; doz., \$2.50.

UMBROSA-Is the London Pride and a dainty plant with erect flowering stems about a foot high and many small white flowers. The foliage is pretty and tufted, and it spreads to form a fine colony. 3 -inch pots. Each, $25 \mathrm{c}$; doz., $\$ 2.50$.

\section{Scabiosa}

CAUCASICA (Blue Bonnet)-One of the handsomest of hardy perennials. 3 feet. Large pale blue flowers on long stems; fine for cutting. 2-year-old. Each, 25c; doz., \$2.50.

COLUMBARIA (New)-Fine orchid-pink flowers on long stems; spreading habit and very free flowering. Flowers slightly smaller than Caucasica but a good companion. 3 -inch pots. $35 \mathrm{c}$ each; doz., $\$ 3.50$.

\section{Shasta Daisy}

ALASRA-A most satisfactory perennial, blooming very profusely for a long period. The flowers are single white, yellow center, and borne on long stiff stems. Extra large clumps. Each, 15c; doz., $\$ 1.25$.

FRINGED-A new semi-double sort with many narrow petals; fine for cutting. Each, 25c; doz., \$2.50.

\section{Sedum (Stonecrop)}

The dwarf varieties are charming plants for sunny positions in the rockery and the taller sorts make effective color groups in the border.

ACRE (Golden Moss) -Foliage green; flowers bright yellow, 2 to 3 inches. May to July. Pot grown. Each, 25c; doz., \$2.50.

ALSUM_Foliage soft green, flowers white. 2 to 3 inches. May to July. Pot grown. Each, 25c; doz., \$2.50.

AIZOON-Coarsely and irregularly toothed foliage, flowers yellow, 12 inches. July and August. Pot grown. Each 25c; doz., \$2.50.

HISPANICUS MINUS-Delicate grayish foliage, very dwarf and mossy. Flowers pinkish white. Pot grown. Each 25c; doz., $\$ 2.50$.

IYDIUM-Daintiest and most dwarfed of the group. Makes dense cushions of light green which in winter assume attractive bright red tints. Flowers pinkish. Pot grown. Each, 25c; doz., $\$ 2.50$.

MORANENSE-A good ground cover, resembles Sedum Acre but has white flowers and is a stronger grower; 3 to 4 inches. Pot grown. Each, $25 \mathrm{c}$; doz., $\$ 2.50$.

SEXANGULARE-Leaves dark green and compact; flowers yellow. 4 inches, July and August. Pot grown. Each, 25c; doz., \$2.50.

SARIIENTOSUIM - A rapid growing, spreading Sedum and the best variety for filling seams between rocks in the wall garden. Flowers bright yellow. May to July. Pot grown. Each, 25c; doz., \$2.50.

SIEBOIDII-Round, succulent, bluish and cream foliage, chang ing to coral-rose. 9 inches. Bright pink flowers in August and September. Pot grown. Each, 25c; doz., \$2.50.

SPATHULIFOLIUM-Glaucous foliage changing to red. Numerous yellow flowers on stems 4 to 8 inches high. Pot grown. Each, 25c; doz., \$2.50.

SPECTABIIE-Brilliant-One of the prettiest erect growing species, attaining a height of 18 inches, with broad light green foliage and immense heads of showy rosy crimson flowers. Fine late fall blooming plant. 4 -inch pots. Each, 25c; doz., \$2.50.

SPURIUM-A flat trailing variety with dense foliage a little over an inch high and purplish-pink flowers on stems 6 inches high during July and August. Foliage of ten assumes bronze tints. Pot grown. Each, 25c; doz., \$2.50.

SPURIOM COCCINEUM-A beautiful rosy-crimson flowered form. 6 inches. July and August. Pot grown. Each, 25c; doz., \$2.50. 
If wanted by parcel post within the 2nd zone, add $10 \mathrm{c}$ for one plant and $3 \mathrm{c}$ extra for each additional plant (except where noted) to cover postage and packing. 6 plants of a variety at dozen rate.

\section{Sempervivum (Houseleek)}

Curious and interesting plants forming rosettes of succulent leaves in varying colors. Good for rockeries and walls.

ARACHNOIDEUM HOOKERI (Cobweb Houseleek)-Tips of leaves in rosette usually connected with silvery threads; flowers bright red in few flowered panicles. 6 inches. Pot grown. Each, 25 ; ; doz., \$2.50.

DOELIIANUM-Small hairy rosettes of pale green leares, tinted red at the tips. The panicles of bright red flowers are 4 to 6 inches high. June and July. Pot grown. Each, 25c; doz., $\$ 2.50$.

FIMBRIATUM-Leaves tipped with a tuft of hairs; flowers bright red in an open panicle. 6 to 10 inches. Pot grown. Each, 25c doz., $\$ 2.50$.

\section{Solidago (Golden Rod)}

CANADENSIS-Well-known golden-yellow, hardy perennial, flowering late in Summer. 3 feet. Strong roots. Each, 20c; doz., \$2.00.

GOIDEN WINGS - The finest of all; 5 feet high with immense panicles of bright golden-yellow flowers from July to September. Strong roots. Each, 20c; doz., $\$ 2.00$

\section{Spiraea (Meadow Sweet) \\ (April Delivery)}

PAIMATA ILEGaNS (Pink Meadow Sweet)-One of the most useful hardy plants with dark green foliage and purple-red stems and branches passing into the silvery-pink of the broad corymbs of flowers, which are produced very freely during June and July. Three to four feet tall. Strong plants. Each, $50 \mathrm{c}$.

\section{Statice (Great Sea Lavender)}

ARBOREA-A graceful plant for the window box, rockery or border with large spreading panicles of deep lavender "everlasting" flowers, which rise from a rosette base of large glossy, leathery leaves. 4 -inch pots. Each, $35 \mathrm{c}$; 5 -inch pots. Each, $50 \mathrm{c}$. (Protect from frost until established).

\section{Stokesia (Cornflower Aster)}

CYANEA-Deep lavender-blue flowers, 4 inches in diameter. Very free bloomer of the easiest culture. 3 -inch pots. Each, $25 \mathrm{c}$; doz., $\$ 2.50$.

\section{Strawberry, Evergreen}

Useful for covering embankments, etc., foliage deep glossy green. Doz., $35 \mathrm{c}$; postpaid, $45 \mathrm{c}$; $100, \$ 2.50$, postpaid.

\section{Streptosolon (Yellow Heliotrope)}

A half hardy perennial, producing masses of showy orange-yellow flowers. 4-inch pots. Each, 35c. 5-inch pots. Each, 50c. (Protect from frost until established).

\section{Sweet William (Dianthus Barbatus)}

A rery desirable low-growing, free-flowering hardy perennial, producing a splendid effect in beds and borders with their rich and varied flowers.

NEWPORT PINK-Brilliant single salmon-rose.

SCARIET BEAUTY-Bright scarlet.

SINGIE MIXED-All colors.

Extra large clumps. Each, 15c; doz., \$1.25.

\section{Thalictrum (Meadow Rue)}

DIPTERIOCARPUM-The finest of all. This hardy perennial is of rigorous growth, 4 to 5 feet high. The dainty rosy purple flowers are brightened by a bunch of conspicuous yellow stamens and produced in graceful sprays from July to September. Clumps. Each, 25c; doz., \$2.50. Extra large clumps. Each $35 \mathrm{c}$; doz., $\$ 3.50$.

\section{Trachelium Coeruleum}

A free-flowering perennial producing large cloud-like heads of pale maure flowers, resembling the Gypsophila; $1 \frac{1}{2}$ feet high. 3-inch pots. Each, 25c; doz., \$2.50.

\section{Thymus (Thyme)}

The Mountain Thymes make a perfect close, fragrant carpet and are a mass of bloom in June and July. Fine for rockwork.

SERPYLIUM AZORICUS (Mother of Thyme)-Dense mats of dark green foliage. Dark red flowers. Pot grown. Each, 25c;
doz., \$2.50.

SERPYLIUM ALBUM (White Mountain Thyme)-Dark green foliage and white flowers. Pot grown. Each, 25c; doz., \$2.50.

SERPYLIUM COCCINEUS - Dark green foliage and brilliant crimson flowers. Pot grown. Each, $25 \mathrm{c}$; doz., \$2.50.

SERPYLIUM LANUGINOSUS (Woolly-Leaved Thyme) Woolly foliage with reddish-pink flowers. Pot grown, Each, 25 c; doz., $\$ 2.50$.

\section{Tritoma (Red Hot Poker)}

Hardy plants with large and broad grassy leaves at the base; the dense spikes of brilliant flowers are borne on long stiff stems during the summer months; withstands drought. PrITZERI_Orange-scarlet spikes, 3 to 4 feet high; very effective.
Clumps. Each, 35 c; doz., $\$ 3.50$.

\section{Tunica Saxifraga}

A pretty tufted plant with tiny light pink flowers, produced all summer. Useful either for the rockery or border. Pot grown. Each, $25 \mathrm{c}$; doz., $\$ 2.50$.

\section{Valerian (Centranthus Ruber)}

Showy, hardy border plants, producing large corymbs of red or white flowers. They are drought-resisting and remain in bloom for many months; 2 to 3 feet tall. Excellent for the shady border.

\section{Verbascum (Mullein)}

OIYMPICUM-A stately hardy perennial plant attaining a height of 6 feet. The large leaves are corered with a silvery down, above which rises a pyramid of bright yellow flowers. 4-inch pots. Each, $35 \mathrm{c}$; doz., $\$ 3.50$.

\section{Herbaceous Veronicas (Speedwell)}

AIPINA A trailing species with small dark blue or violet flowers on stems 2 to 6 inches high. It requires a rich, well drained soil and full sun. A good rock plant. Pot grown. Each, 25c; doz., $\$ 2.50$.

IONGIFOIIA-Forms a bushy plant, 2 to 3 feet high, with long dense spikes of deep blue flowers from July until early September. 4-inch pots. Each, 25c; doz., \$2.50.

SPICATA-Another attractive variety for the border with bright blue flowers, borne in long compact spikes, during July and August, $11 / 2$ feet high. 4 -inch pots. Each, 25c; doz., $\$ 2.50$.

\section{Viola (Tufted Pansy)}

JERSEY GEM-A superb new rariety with pure violet-blue flowers which have a little perfume. The plant is of compact, sturdy habit of growth and the flowers are borne on good stems about 6 inches long, making it ideal for cutting as well as a most desirable plant for the border or rockery. 3-inch pots. Each, $25 \mathrm{c}$; doz., $\$ 2.50$.

\section{Violets}

CAIIFORNIA-Large, single dark blue. Strong roots. Doz., 50c; postpaid, $60 \mathrm{c} ; 100, \$ 3.50$ postpaid.

MARIE IOUISE-Double larender-blue with whitish center. Doz., $50 \mathrm{c}$; postpaid, $60 \mathrm{c} ; 100, \$ 3.50$ postpaid.

SWANLEY WHITE-Double white. Doz., 50c; postpaid, 60c; 100 , $\$ 3.50$ postpaid.

\section{Woodwardia Radicans}

The best hardy native fern for outdoor planting. doing best in partial shade. Bright green fronds 2 to 4 feet long. Clumps, each, $50 \mathrm{c}$; postpaid, $60 \mathrm{c}$. Larger clumps, each, $75 \mathrm{c}$; postpaid, $90 \mathrm{c}$. 


\title{
FRUIT TREES AND SMALL FRUITS
}

\author{
SPECIAL NOTICE TO PURCHASERS
}

The 10 rate applies on an assortment of all varieties of fruit trees listed as 65 c. each or $\$ 6.00$ per 10 .

While we aim to have all our fruit trees to name, and hold ourselves ready, on proper proof, to replace, free of charge, all stock that may prove untrue to label, or to refund amount originally paid by the customer, it is mutually understood and agreed between the purchaser and ourselves that our guarantee of genuineness shall not make us liable for any sun greater than that originally paid us for such stock as may prove untrue.

\section{PLANTING AND PRUNING FRUIT TREES}

PLANTING-Successful planters always dig good large holes for the roots. A little extra labor at this time will be amply repaid in the more rapid growth of the tree, and should the ground be at all heavy or sandy, add some old welldecayed manure. After the tree is set in the hole properly, commence to throw in the soil gently, and see that it is well pulverized, and work all in around the roots well. After the hole is half filled up, press down gently with the foot; then fill in the remainder, also going through the same process, leaving the last spadeful or two untrodden. Never, especially in soils that are apt to run together, or adobe, try to plant when the ground is wet. Wait until the ground dries; otherwise your trees will not grow so well.

Planting can be done from December to March, according to the season, but orders should be placed early with us, so as to obtain desired selections.

\section{Frequent cultivating is necessary, as there is no better way of keeping the moisture near the surface.}

PRUNING-All deciduous fruit trees should be pruned back severely after planting, usually $21 / 2$ or 3 feet from the ground, according to the size of the tree, leaving a few side branches where necessary, which are cut back to a few inches from the main stem. Heading back promotes a vigorous new growth and a stocky tree, provides shade which protects the trunk from sunburn and the fruit being nearer the ground is more easily picked. When these trees have been planted one year, cut back at least half of the preceding summer's growth. Thus a framework is established for the tree.

\section{Apples}

The first winter after planting the branches should be cut back at least one-half and thinned out so as not to leave more than four branches for the framework. The second winter not more than two laterals should be allowed to remain on the branches whose growth should again be shortened very severely. With the head now practically formed the grower must shape the tree in accordance with its development by shortening the laterals where necessary and thinning out surplus shoots. It is not desirable to shorten-in apples as is done with the apricot and peach.

\section{Price, 4 to 6 feet, $65 \mathrm{c}$ each; $\$ 6.00$ per 10}

BALDWIN - Large, roundish, deep bright red over a yellow ground; flesh yellowish white, crisp, juicy, sub-acid. Ripe in November and December.

BISMARCK-Large yellow with red cheek; a fine eating and cooking sort, also a good keeping winter apple. Very prolific and comes into bearing quicker than any other kind. Ripens in Winter.

DELICIOUS-Dark red splashed with golden yellow. Fine-grained and highly flavored. Ripe in November.

ESOPUS-SPITZENBURG-Large, light red; rich, sprightly, vinous flavor. One of the best. November to January.

GRA VENSTEIN-A large, striped, beautiful, roundish apple; of excellent quality, juicy, highly flavored. A good grower and prolific bearer. Ripe in August.

JONATHAN_Medium to large, conical, striped, mostly red, rich flavor, very productive and good keeper. Ripe in October to December.

RED ASTRACHAN-Large, roundish, skin deep red; flesh white, juicy and crisp, though rather acid. A hardy, vigorous and early bearer. The best early apple. Ripe in June and July.

ROME BEAUTY-Large yellow striped with bright red; very handsome; flesh tender, juicy, sprightly. A long keeper. Ripe in November and December.

WINTER BANANA - Medium to large golden yellow usually shaded crimson. Flesh fine-grained with a very rich sub-acid flavor; commences bearing very young. Ripe October to December.
YELLOW BELLFLOWER-Very large, oblong; skin smooth and of pale lemon color; flesh firm but tender, juicy and sub-acid. very productive. Ripens November to February.

YELLOW NEWTOWN PIPPIN-Another variety very successfully grown in California. Large; fiesh yellow, firm, crisp, juicy, of exceedingly rich flavor. The best Winter apple. Ripe January to March.

\section{Crab Apples}

These require the same pruning as apples. Price, 4 to 6 feet, $65 \mathrm{c}$ each; $\$ 6.00$ per 10

RED SIBERIAN-Fruit about an inch in diameter. Yellow with a scarlet cheek. An erect, free grower. Bears very young.

TRANSCENDENT-Fruit very large; yellow striped red.

\section{Apricots}

The method of pruning recommended for the peach applies to the apricot and the only exception is that summer pruning is resorted to immediately after the crop is harvested by removing one-half or more of the new growth and thinning out enough new and old wood to prevent the tree from becoming thick and bushy.

\section{Price, 4 to 6 feet, 65c each; $\$ 6.00$ per 10}

BLENHEIM-An excellent variety and in great demand. The trees are early and regular bearers and have an abundance of foliage thoroughly protecting the fruit. Fruit above medium, oval; orange color, with deep yellow, juicy and rich flesh; July.

HEMSKIRKE_Large, roundish; flesh bright orange, tender and juicy, with a rich plum-like flavor; fruit not quite as large as the Moorpark, but ripening more evenly. August.

MOORPARK-Very large, yellowish-green, brownish-red on the sunny side, marked with numerous dark specks and dots; flesh bright orange, parts freely from the stone. July.

ROYAI-A very fine apricot, very extensively planted in this State. Of medium size, yellow with red cheek: immenselv productive: an early ripening variety. June. 


\section{Almonds}

When pruning young trees leave two or three of the side branches, cutting these back to two or three eyes, as almonds sometimes will not bud from the main stem.

The tree should be headed low and pruned during the first three rears to secure a shapely, strong tree. After the third sear little pruning is required except to thin out objectionäble branches by winter pruning.

\section{Price, 4 to 6 feet, $65 \mathrm{c}$ each; $\$ 6.00$ per 10}

I. $\mathbf{X}$. I-Tree a sturdy, upright grower, with large leaves, nuts large; shells easily, no machine being needed nor is any bleaching necessary; shell soft but perfect. It bears heavily and regularly.

NE PIUS ULTRA-Tree a rapid grower; leaves rather large; a heary and regular bearer; nuts large and very long in shape: soft shells; hulls freely.

NONPAREII-Of weeping style of growth but still forms a beautiful tree. An extraordinarily heary and regular bearer with very thin shell.

\section{Cherries}

Prune the same as any other deciduous fruit tree until about fire years old, allowing only three branches to form the head. After that the less pruning the better, except when necessary to cut out a dead or crossing branch.

\section{Price, 4 to 6 feet, 65c each; $\$ 6.00$ per 10}

BING-Fruit large, dark brown or black; very fine; June. BIACK TARTARIAN-Very large, bright black. Late May. EARIY RICHMOND-A red sour "pie cherry."

ROYAI ANN (Napoleon Bigarreau) -Very large, amber in color. The favorite white cherry. Late June.

\section{Nectarines}

When pruning newly planted trees always leare one or two of the lateral branches, cutting these back to two or three inches. From three to five branches should form the head of the tree and these should be cut back to twelve inches the first winter after planting. The second winter a severe heading back agrain should take place and not leaving over one-quarter of the new growth and allowing onlp a few laterals to remain. The third season two shoots should be allowed to start from the branches of the rear before and they in turn should have their growth shortened in two-thirds. Never neglect to follow up the pruning of Nectarine and Peach trees every year no matter how old.

Price, 4 to 6 feet, 65c each; $\$ 6.00$ per 10

BOSTON-Large, deep yellow, with a bright blush and deep mottlings of red; flesh yellow, without any red at the stone. Sweet though not rich, with a pleasant and peculiar flavor. Ripe late in July.

EARLY VIOLET-Fruit large size, flesh white, tender, juicy and of delicious flavor. Ripe early in $\mathrm{July}$.

\section{Pears}

Prune the same as Apples.

Price, 4 to 5 feet, $65 \mathrm{c}$ each; $\$ 6.00$ per 10

Except Seckel, 3 feet, at same price.

BARTIETT-There is no occasion to describe this variety, so well known is it. A vigorous and strong grower. Bears heavily; good for shipping and canning. August.

DOYENNE DU COMICE - Large greenish-yellow shaded with crimson. Ripe in October.

SECKEL-Quite small; rich yellowish brown; very sweet and productive. Ripe in September.

WINTER NEIIS-Medium size, roundish, yellowish green, dotted with russet. Fine flavor. November to January.

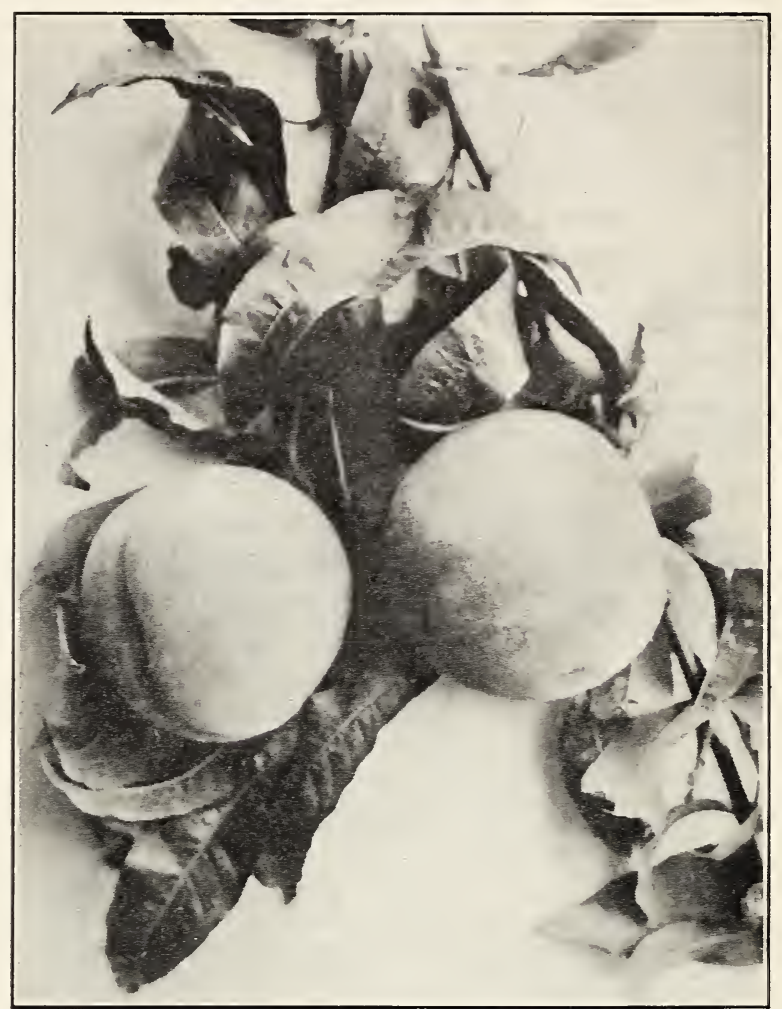

Alexander Peach

\section{Peaches}

The trees require the same pruning as Nectarines. Price, 4 to 6 feet, $65 \mathrm{c}$ each; $\$ 6.00$ per 10 .

ALEXANDER - Generally known as the Strawberry Peach. Medium size, skin greenish white nearly corered with rich red; flesh firm and juicy, sweet. Early June.

ELBERTA-Very large, bright yellow with a beautiful red mottled cheek; juicy and sweet; regular bearer. Ripens about end of July.

EARIY CRAWFORD - This is probably the most extensively grown of all peaches. Very large; color yellow, red cheek flesh yellow, rich, excellent. Very productive. Ripens about middle of July.

HAIE'S EARIY-Large, greenish white, mostly covered with red; flesh white, melting, juicy and sweet.

IATE CRAWFORD_Very large; yellow with dark red cheek; flesh deep yellow, juicy and melting; of exquisite flavor; valuable for canning and drying. Ripens middle to end of August.

IEMON CLING - Large yellow; flesh firm and clear yellow. August.

MUIR-Has a delicious, rich buttery sweet flavor; fruit is large: skin pure yellow; flesh yellow. As a drying peach it excels all others. Ripens end of August.

SAIWAY_A large, yellow English peach, with deep yellow flesh; very juicy, melting and rich. The most valuable late market variety. Ripens in August.

TUSCAN CIING - Very large, yellow to the pit; very heavy bearer. Ripens middle of July.

WHITE HEATH CLING-Skin downy, creamy white, with faint blush of red; flesh white, slightly red at the pit; very tender. juicy and sweet. Ripens middle of September. 


\section{Plums}

Plums and Prunes being sprawling growers, the trees should be pruned quite severely until five years old, after that the pruning should be confined to removing interfering branches and dispensing with the shortening in of the side branches.

Price, 4 to 6 feet, 65c each; $\$ 6.00$ per 10.

APEX PLUMCOT-A new variety. Fruit very large; color deep pink: freestone; flesh yellow, firm and rich. Early.

BURBANK (Japanese) - Large, yellowish ground, with red cheek; flesh yellow; firm. Late June.

CLIMAX-Very large, heart shaped; skin thick, firm, deep vermilion red; flesh yellow and very rich. July.

DAMSON-Dark purple, tart flavor; excellent for preserves.

GREEN GAGE-Small, but of the fine quality; round greenishyellow, with brown dots; juicy and sweet. August.

SANTA ROSA-Deep purplish-crimson, very large and extremely early, ripening the middle of June.

SATSUMA-Large; blood-red flesh; of fine flavor.

WASHINGTON-Large, roundish; deep yellow, with pale crimson blush; flesh yellow, firm, sweet and luscious. July and August.

YELLOW EGG-Very large; egg-shaped; flesh yellow, rather acid until fully ripe, when it sweetens. Clingstone.

\section{Prunes}

Price, 4 to 6 feet, 65c each; $\$ 6.00$ per 10 .

FRENCH (Petite d'Agen) - This is the prune now grown so extensively and successfully in California for drying purposes; medium-sized; egg-shaped, violet purple; very rich and sugary. Prolific bearer. August.

GERMAN-Long, oval, and swollen on one side; skin purple, with a thick blue bloom; flesh firm, green, sweet with a peculiarly pleasant flavor. Separates readily from the stone. September.

HUNGARIAN-Fruit very large, with tendency to come double; reddish violet, covered with a handsome bloom. Very juicy and sweet. Good shipper. September.

IMPERIAI EPINEUSE-Very large, violet purple, exceedingly sweet. September.

SUGAR - An extremely early prune. Very large. Ripens August 1st. Skin very tender, at first of a light purple, tinted with green, changing at maturity to dark purple, covered with a thick white bloom. Early August.

TRAGEDY_Dark purple; flesh yellowish green; very rich and sweet. Early July.

\section{Figs}

After the first winter cut the branches back to twelve inches and cover the wounds with grafting wax, leaving not more than four branches to make the head of the tree. The second season cut not less than two-thirds of the new growth, leaving not more than two shoots on each of the frame work branches. After the third season shorten in the new growth about half and in after years there is little pruning necessary except to remove branches which cross and interfere with each other.

Price, 4 to 5 feet, $65 \mathrm{c}$ each; $\$ 6.00$ per 10.

CAIIFORNIA BLACK-A well-known local variety. Large dark purple, almost black when fully ripe. Makes a good dried fig. Tree grows to a very large size, and gives immense yield.

WHITE ADRIATIC - Fruit large; skin greenish-yellow color: pulp carnation red. Ripens from August to October.

KADOTA-Medium sized, thin white skin; pulp white to pink. One of the best for canning, preserving and pickling.

\section{Quinces}

After the trees commence bearing they require practically no pruning, except to remove defective branches.

Price, 4 to 6 feet, $65 \mathrm{c}$ each; $\$ 6.00$ per 10.

APPLE or ORANGE-Large, bright yellow. The best. Ripe August and September.

PINEAPPLE-Very fine flavor. Large,

\section{Walnuts}

Cut back the frame work branches one-half the first winter after planting, pruning the laterals in the same manner the second winter and thinning out where there is a ten. dency to overcrowding, followed by a moderate treatment in the third winter and the checking of rank growth in the fourth and subsequent years.

FRANQUETTE-Nut is quite large, of an elongated oval shape and very attractive; kernel full, sweet and of a rich, nutty flavor; a late bloomer. Grafted on California Black Walnut root. 4 to 6 feet, $\$ 1.75$ each; $\$ 15.00$ per 10.

MAYETTE-A very superior nut in every way. Tree an abundant bearer and very late bloomer. Grafted on California Black Walnut root, 4 to 6 feet, $\$ 1.75$ each; $\$ 15.00$ per 10 .

\section{Pomegranates}

The natural habit of the Pomegranate is to grow bushy. If pruned heavily it will not bear well.

WONDERFUL_4 to 5 feet, 70c each.

\section{Persimmon}

After the head of the tree is established follow the same method of pruning as is recommended for the peach trees for the first three seasons. After which time very little pruning is necessary.

HACHIYA - Fruit very large, oblong and pointed; skin bright red and flesh deep yellow. 4 to 6 feet. $\$ 1.75$ each.

\section{Mulberry}

PERSIAN-Tree of rather slow growth, but bears young and produces the largest and finest fruit of all mulberries. The fruit is black, one to one and a half inches long with a fine flavor. Commences to ripen in early Summer and bears continually until late Fall. 3 to 4 feet. $\$ 1.50$ each.

\section{Olives}

MISSION-Fruit medium to large, excellent pickles; makes a superior oil. \$1.25 each.

\section{CITRUS FRUITS}

Great care should be taken not to allow the ball of earth around the roots to dry out before planting. When planting do not break the ball of earth and leave the burlap around the earth, as this soon rots. The trees should be set from one to two inches deeper than in the nursery. Leave a basin around the tree and fill this with water. When the earth is dry enough to break up fine, cultivate carefully and irrigate every ten days or two weeks, until the trees begin to grow; after that irrigation is a matter of weather conditions, but never allow the trees to suffer for water. Citrus trees being an evergreen can be planted at all seasons of the year although the months of March, April, May and June are considered the most favorable.

\section{Oranges}

Balled 4 to 5 feet. Extra Select. $\$ 4.00$ each.

RIVERSIDE WASHINGTON NAVEL-Fruit first-class in every respect; size medium to large, oval, smooth, symmetrical, seedless, pulp fine grained, flavor excellent. A solid, perfect fruit.

VAIENCIA LATE-A vigorous grower, making a handsome tree, early in bearing and very prolific; fruit medium sized, skin thin, light color; flesh deep rich color, fine grained and very juicy. Ripens in May and June.

\section{Lemons}

Balled 4 to 5 feet. Extra Select. $\$ 4.00$ each.

EUREKA - Tree nearly thornless, of rapid growth, and prolific bearer; fruit of the best quality. A general favorite.

\section{Limes}

Balled 4 feet. $\$ 4.00$ each.

BEARSS SEFDLESS-Very large; very juicy with pronounced acidity. Hardy and enormously productive.

\section{Pomelos (Grape Fruit)}

Balled 4 to 5 feet. Extra Select. $\$ 4.00$ each.

MARSH'S SFFDIFSS-Medium, practically seedless, skin thin and smooth; pulp juicy, of superior flavor. Keeps late. A valuable acquisition; its delicious flavor and having no seeds should cause it to take the precedence over many other varieties. 


\section{Grapes}

Prices, 25c. each, $\$ 2.00$ per 10, excepting Isabella, Concord and Niagara, which are 35c each, $\$ 3.00$ per 10.

AIICANTE BOUSCHET-A very fine juice grape with deep red juice. September.

BIACK HAMBURG-Black, very large and oblong. September. CONCORD_Black, August.

FLAME TOKAX-Red, September.

ISABELIA REGIA or PIERCE-Bluish-black, September.

MUSCAT_Pale amber, August-September.

NIAGARA-Pale yellow, September.

THOMPSON'S SEEDLESS-Yellow, August.

ZINFANDEL_Dark purple juice grape. September.

\section{Strawberries}

Prepaid anywhere within the second zone.

To cultivate the Strawberry for family use we recommend planting in beds 4 feet wide, with an alley 2 feet wide between the beds. These beds will accommodate 3 rows of plants, which may stand 15 inches apart each way, and the outside row 9 inches from the alley. The beds can be kept clean easier and the fruit gathered without setting feet upon them. The ground should be well prepared by digging at least 10 or 12 inches deep, and be enriched with wellrotted manure, ground bone, or any other good fertilizer. In order to obtain large, highly flavored fruit, pinch off the runners as fast as they appear and this will cause the plants to stock out. The earlier they are planted in the season the better crop you will have the first season.

BANNER-The most popular and best strawberry ever grown. Fruit of this sort may be picked from March until December in most localities. The plants we carry are guaranteed to be the "Genuine Banner" stock. Extra large, well rooted plants. 35c per dozen; $\$ 2.50$ per 100 .

OREGON EVERBEARING-A vigorous grower, fruit of medium to large size; an even and abundant bearer, of good color and texture; flavor sweet and delicious. 35c per dozen; $\$ 2.50$ per 100.

MARSHAII_Of enormous size, blood red color, rich aromatic flavor. 35c per dozen; $\$ 2.50$ per 100.

\section{Currants}

Each, 30c; postpaid, 45c; 10 for $\$ 2.50$; postpaid, $\$ 2.85$

Currants and Gooseberries should be planted in rows 5 to 6 feet apart and 2 to 3 feet apart in the row. Trim out the old wood as it begins to decline and shorten the young shoots in spring as may be desired in order to keep the bushes in good shape. A good soil is required which must be kept rich and well worked. Sprinkle wood ashes around the roots occasionally to keep the borers away.

CHERRY CURRANT_-Very large, deep red.

\section{Gooseberries}

Each, 30c; postpaid, 45c; 10 for $\$ 2.50$; postpaid, $\$ 2.85$

CHAMPION-Berries large and brownish red; very sweet and fine for table use and pies. Strong grower; prolific bearer.

DOWNING-Fruit good sized, whitish green, flesh soft and juicy, vigorous grower.

\section{Rhubarb}

Large Roots. Each, 25c; postpaid, 35c. 5 for $\$ 1.00$; postpaid, \$1.15. Plant in deep rich soil in rows 4 feet apart and 3 feet apart in the row. Set the roots so that the crowns are about an inch below the surface.

BURBANI'S GIANT CRIMSON WINTER-A robust grower and prolific producer of mammoth stalks of fine flavor, three times the size of the older sorts, thrives very well during the winter months.

STRAWBERRY_Large stalks; very tender and fine. Of the best quality.

\section{Blackberries}

If wanted by parcels post within the second zone, add postage as follows: 10c. for 1 plant; 15c. for 5 plants; 25c. for 10 plants.

Plant in good soil, in rows 6 to 8 feet apart, and 4 feet apart in the row. Each year after the leaves have fallen cut off the canes that fruited during the summer. Allow the new canes which have sprouted to remain for the coming season as it is the new growth that produces the choicest fruit. After the new canes have grown 5 to 6 feet, prune off the tips of each cane to force out the side branches, providing you intend to stake or trellis. If you intend to let the plants stand alone, pinch off the tips when canes are 2 to 4 feet high. A good top dressing of well rotted manure should be applied as soon as the patch is cleaned up.

CORY THORNLESS MAMMOTH_This berry grows on vines or stalks, smooth and free from thorns, and it is the largest of all blackberries. It has a delicious flavor of its own, somewhat resembling the wild blackberry. Another feature is that it is almost seedless. One-year old plants, 25c each; \$2.00 per 10.

HIMALAYA GIANT-A late Blackberry, coming after the other berries are gone, ripening over a period of several weeks, making it especially desirable for family use. Like the Loganberry and Mammoth Blackberry, it must be grown on a trellis. The berries grow in bunches, are of excellent flavor and the yield is tremendously large. One-year-old plants. 25c each; $\$ 2.00$ per 10.

MAMMOTH BIACKBERRY (Named by some "The Black Loganberry") - The fruit is very large, some specimens measuring from $2 \frac{1}{4}$ to $2 \frac{1}{2}$ inches long; extra fine flavor. Enormously productive and quite early. One-year-old plants. 25c each; $\$ 2.00$ per 10.

LOGANBERRY (Raspberry-Blackberry)- The fruit is often an inch and a quarter long, dark red, with the shape of a blackberry, the color of a raspberry and the flavor a combination of both. The vines are strong growers and the yield is exceedingly heavy. One-year-old plants. 25c each; $\$ 2.00$ per 10.

PHENOMENAI BERRY-Berries very large, of a bright crimson raspberry color. Berries in clusters of 5 to 10 ; very productive. One-year-old plants. 30c each; $\$ 2.50$ per 10.

\section{Raspberries}

If wanted by parcels post within the second zone, add postage as follows: 10c. for 1 plant; $15 \mathrm{c}$. for 5 plants; $25 \mathrm{c}$. for 10 plants.

Plant in rows 5 to 6 feet apart, 2 to 4 feet in the row. After the fruit season cut out all the old wood which bore the last crop of fruit. Pinch the vigorous young shoots several times during the Summer. They will then grow stout enough to stand without staking.

CUTHBFRT-Large crimson variety and very productive; bears transportation well. $15 \mathrm{c}$ each; $\$ 1.00$ per 10 .

IA FRANCE-The Giant Everbearing Red Raspberry. Superior to any other Raspberry. Produces large juicy berries of finest aroma; very prolific; heavy bearer, absolutely hardy and free from disease; bears from June until November. 30c each: $\$ \mathbf{2 . 5 0}$ per 10.

RANIFRE-The most popular everbearing red raspberry. It commences to bear a big crop of large bright crimson berries of the finest quality in June and begins again in September and bears continuously until Christmas. 20c each; \$1.50 per 10. 


\title{
Insecticides and Fungicides
}

\author{
FOR ALL PESTS AND FUNGOUS DISEASES
}

Insecticides should be sent by express or freight. Those that may be sent by Parcel Post are marked mailable; please add postage when ordering, except where postpaid prices are given; others are F. O. B. San Francisco, Cal., and prices subject to change without notice.

AII ROUND SPRAY (Acme)-A combination spray which will combat blight and fungous diseases, control sucking insects and destroy chewing insects in one application. $1 / 4$ lb., 35c; lb., 85 c. (Unmailable).

ANTROI-For Ants. See page 92.

ANT DESTROYER, SHRADER'S-Gets the nest as well as the parents because it is slow-acting and does not kill instantly. Not a poison. Packages 25c, 50c and $\$ 1.00$ each. (Mailable; add $5 \mathrm{c}$ per package for postage).

ARSENATE OF IEAD. Dry Powdered-A dry, very finely powdered arsenate of lead which may be dusted or sprayed. Use about 3 lbs. per 100 gallons of water. Does not burn the leaves. $1 / 2$ lb., 30c; 1 lb., 45c; 4-lb. bag, \$1.25. (Unmailable).

"BIACK IEAF 40"-A concentrated nicotine solution for aphis and thrip. Dilute one ounce to 3 gallons of water. 1 oz. bottle, $35 \mathrm{c} ; 1 / 2 \mathrm{lb}$. bottle, $\$ 1.25 ; 2 \mathrm{lb}$. can, $\$ 3.25 ; 10 \mathrm{lb}$. can, $\$ 11.85$. (Unmailable).

BORDEAUX MIXTURE-A Quality Bordeaux Mixture in dry form. The best and most generally used spray for blight, mil dew, curled leaf, pear scab, etc. All prepared and ready for use. One pound makes 6 gallons of spray. 1 lb., $40 \mathrm{c}$; 4 lbs., \$1.00. (Unmailable).

CAICIUM ARSENATE_-1 lb., 35c; 4 lbs., \$1.00. (Unmailable).

DRY IIME \& SUIPHUR For use in dormant spraying before the buds show green at the tips in Spring against scale, peach blight. leafcurl. One pound makes 4 gallons of spray. 1 lb. 35c; 5 lbs., \$1.35; 10 lbs., \$2.50. (Mailable, postage extra).

EVERGREEN-A highly effective, non-poisonous insecticide for aphis, thrips, mealy bug. white fly, beetles, cabbage worms and many other insects. (Write for spray chart on the use of same.) $11 / 2$ oz, bottle (makes up to 9 gallons sprav) 35c; 6 oz. bottle, \$1.00; $16 \mathrm{oz}$. bottle, $\$ 2.00$; 32 oz. bottle, \$3.85. (Mailable, postage extra).

IIME, HYDRATED - 5-1b. package, 25c; 10-1b. package. 45c. (Mailable, postage extra.) $50 \mathrm{lbs.,} \$ \mathbf{1 . 5 0}$, by express or freight.

IIME AND SULPHUR ("Orchard Brand") - Kills San Jose scale, bark lice, etc. Apply, when trees are dormant before the buds show green at the tips in Spring. One gallon makes 7 gallons of spray. 1-qt. can, 30c; 1-gal. can, 60c; 5-gal. cans, \$2.25. (Unmailable).

MISCIBLE OIL (Spray Emulsion)-A general spray for killing scale, green lice and other pests that suck. Dilute 5 tablespoonfuls to each gallon of water. Full strength. Pint, $35 \mathrm{c}$; quart, $50 \mathrm{c}$; $1 / 2$-gal., $75 \mathrm{c}$; gallon, $\$ 1.00$. (Mailable; postage extra.)

NICO GARDEN DUST COMPLETE-Contains nicotine. sulphuT, tobacco dust, arsenate of lead and the inert carrier. This combined dust will eradicate aphides, red spiders, chewing inserts and will also control mildew. $1 / 2$ lb. self-blowing carton. $25 \mathrm{c}$; $1 \mathrm{lb}$. sifter top cartons, 60c; 5 lb. containers, \$2.25. (Mailable; postage extra).

NICO DUST No. 10 - Contains $10 \%$ Black Leaf " 40 ". A very strong dust mixture used for the control of asparagus aphides, cantaloupe aphides, pea aphides, leaf hoppers, flea heetles, cucumber beetles, squash bugs, etc. $1 \mathrm{lb}$. cans, 60c; 5 lb. cans, \$2.25. (Mailable; postage extra).

NICO-FUME IIQUID-Contains 40 per cent nicotine. Place a hot iron in $1 \mathrm{~T} / 2$ pints of water to which a scant tablespoonful of Nico-Fume has been added. This will kill greenhouse pests over 600 square feet. $1 / 4-1 b$. can, 75 c; $1-1 b$. can, $\$ 2.00 ; 4-1 b$. can, $\$ 6.25$. (Unmailable.)
NICOTINE MISCIBLE OIL-For the control of scale, dilute $\mathbf{5}$ tablespoonfuls to each gallon of water. For aphis, dilute $21 / 2$ tablespoonfuls to each gallon of water. 6-oz., 35c; pint, $65 \mathrm{c}$; quart, $\$ 1.00 ; 1 / 2-$ gallon, $\$ 1.50 ;$ gallon, $\$ 2.25$. (Mailable; postage extra.)

NICOTINE SPRAY (Mapco)-Kills green and black aphis and other sucking insects. Made from genuine whale oil with nicotine. Mixes instantly with cold water. Dilute 2 tablespoonfuls to each quart of water. 6 oz., $35 \mathrm{c}$; pint, $65 \mathrm{c}$; quart, $\$ 1.00$. (Mailable, postage extra.)

NICO-FUME TOBACCO PAPER-Strongly saturated with nicotine. Merely suspend from bench and light lower end. One sheet is destructive to 2,000 cubic feet. Air-tight can of 24 sheets, $\$ 1.25$, postpaid, $\$ 1.35 ; 144$ sheets, $\$ 5.00$, postpaid $\$ 5.15$.

NIKOTEEN-An economical tobacco extract containing 30 per cent nicotine. A very effective remedy against aphis and $\mathrm{fly}$ insects. 1-1b. bottle, \$2.25. (Unnailable.)

PARACIDE (Para-Dicholor-Benzene) - For Peach Tree Borer which attacks roots of nearly all stone fruits. Apply in fall or spring. Circular sent with each tin or on request. $1 \mathrm{lb}$, $60 \mathrm{c}$. (Mailable; postage extra).

PARIS GREEN-In cans, pure, poisonous. Kills caterpillars, potato bugs, sow bugs and all bugs which chew the leaves. $1 / 4-1 b$., 25c; 1 lb., 75c; 5 lbs., \$2.50. (Unmailable.)

QUA-SUI_A sulphur carbon combination. The best remedy for mildew and fungoid diseases. 4-oz. bottle, sufficient for $3 \mathrm{gal}$ lons of spray, 25c: 8-oz. bottle, 40c; 1 quart, sufficient for 25 gallons of spray $\$ 1.00$; 1-gal. can, $\$ 3.75$. (Mailable; postage extra.)

SEMESAN (Du Pont) -A mercuric disinfectant for the control of diseases of seeds, bulbs, roots and tubers, also for damping off control and for treating brown patch of lawns. 2 oz., $50 \mathrm{c}$; $1 \mathrm{lb}$., \$2.75. (Unmailable).

SLUG SHOT-A fine powder for destroying cabbage worms, slugs and caterpillars. 1-lb. carton with perforated top for applying, 25c. (Mailable; postage extra).

SIUG SIUGGER-A meal poison for the control of snails and slugs. Scatter the poison evenly on the ground and sprinkle lightly every evening before dark. for a week. in order to keep the compound moist. 1-lb. can, $40 \mathrm{c} ; 2 \mathrm{x} / 2 \mathrm{lbs}$., $75 \mathrm{c} ; 5$ lbs., $\$ 1.25$. (Unmailable).

SNAROL_For slugs and snails. See page 92.

SULPFUR ("Anchor Brand")-For dry dusting of vines and nlants for controlling mildew and other fungous diseases. Lb., 10c: $10 \mathrm{lbs} ., 75 \mathrm{c}$. Prices on larger quantities on application. (Mailable; postage extra.)

TOBACCO DUST (“C. B. P. Brand”)-A very fine grade which contains 15 per cent nicotine. Lb., 15c: 5 lbs., 60c; 10 lbs., \$1.15; 25 lbs., \$2.50; 100 lbs., \$7.50.' (Mailable; postage extra).

2-WAY SPRAY (Acme)-An approved balanced combination spray for combating chewing insects and fungous diseases in one application. Can be applied as a dust as well as in a liquid spray if desired. Is composed of 14 per cent arsenate of lead and 83 per cent Bordeaux Mixture. $1 / 2-1$ b. carton, 25c; 1-1b. carton, $45 \mathrm{c}$; 4 lb. paper bag, \$1.25. (Unmailable.) 


\section{Insecticides and Fungicides-Continued}

TREE TANGLEFOOT-A sticky substance applied directly to bark of trees for protecting them against ants and climbing insect pests. One application remains sticky on the trees for three months. Easily applied. One pound will spread 8 feet long by 5 inches wide. 1 lb., 60c; 5 lbs., \$2.75; 10 lbs., \$5.25. (Mailable; postage extra.)

VOLCK-A powerful insecticide for the control of mealy bugs, scale insects, white flies, rust mites and red spiders. Can be used with nicotine for the control of aphis and thrips. One application kills eggs, young and adults. Economical enough to use on big trees. Easy to mix. $1 / 2$ pint, $40 \mathrm{c}$; makes two gallons of spray. Pints, 55c; quart, 80c; gallon, \$2.15; 5 gallons, \$9.10. Small cans mailable, postage extra; 5 gállons by express or freight.

WHALE OIL (Liquid)-6 oz., 25c; pint, 35c; quart, $50 \mathrm{c}$; $1 / 2$ gal., $75 \mathrm{c}$; gallon, $\$ 1.00$. (Mailable; postage extra.)
WHALE OIL SOAP ("Genuine")-Dissolved in water makes an excellent spray for scale on palms, etc. 1-1b. can, 30c; 5-1b. can, $\$ 1.25$; $10-1 b$. can, $\$ 2.25$. (Mailable; postage extra.)

WILSON'S O. K. PLANT SPRAY-A powerful, yet harmless and efficient insecticide for the control of red spider, aphis and thrip. For the prevention of snapdragon rust spray once a week. Quart, $\$ 1.00$; gallon, $\$ 3.00$.

\section{Weed Killers}

K. M. G.-Kills morning glory and other weeds. A liquid chemical spray which is diluted or sprayed on the plant. Will not injure the soil. Quart, $\$ 1.25$; gallon, $\$ 2.50 ; 5$ gallons, $\$ 10.00$. (Unmailable.)

K. M. G. DANDELION KILLER-For destroying dandelions. 7oz. bottle, with automatic drop regulator in stopper, $\$ 1.00$. (Unmailable.)

\section{Spray Chart for the Control of Insects and Diseases}

\section{DECIDUOUS TREES}

SAN JOSE SCALE AND OTHER SCALES-Spray either in the fali after the leaves drop or in the spring when trees are still dormant with solution of ten level tablespoonfuls of Dry Lime Sulphur to each gallon of water. For summer spraying use three tablespoonfuls to one gallon of water.

PEACH LEAF CURL-Spray either in the fall after the leaves drop or in the spring before the buds swell with solution of ten tablespoonfuls of Dry Lime Sulphur to one gallon of water.

CODIIN MOTH (The Cause of Wormy Apples and Pears)After the petals of the blossom are about one-half fallen, before the calyx closes, spray with a solution of about three level tablespoonfuls of Dry Arsenate of Lead to each gallon of water. Repeat in two weeks and give extra sprays should worms appear.

CHERRY OR PEAR SLUG-When slugs appear, spray with a solution of about three level tablespoonfuls of Dry Arsenate of Lead to each gallon of water.

APHIS (Green or Black Fly)-Spray as soon as lice appear with solution of one and a quarter teaspoonfuls of "Black Leaf 40 " nicotine to each gallon of water to which add a small quantity of Whale Oil Soap. Repeat at intervals of a few days until lice disappear.

WOOLLY APHIS-Spray with a solution of 6 to 8 tablespoonfuls of Nicotine Miscible Oil to each gallon of water or spray with a solution of 5 level tablespoonfuls of Volck to each gallon of water and repeat at intervals of two or three weeks.

CLIMBING INSECTS-To prevent ants and other insects from entering trees apply Tree Tanglefoot.

\section{ROSES}

APHIS (Green or Black Fly)-Apply "Black Leaf 40" nicotine, "Evergreen" or Nicotine Miscible Oil.

ROSE SCALE AND FUNGUS_Spray with Dry Lime Sulphur as recommended for the control of San Jose Scale.

ROSE WORMS-Spray with a solution of twelve level tablespoonfuls of All Round Spray which will combat mildew and rust as well as kill the worms. Repeat in two weeks if necessary. Dry Arsenate of Lead is also recommended.

RUST_Spray with a solution of eight level tablespoonfuls of Bordeaux Mixture to each gallon of water.
MILDEW-To prevent this disease from spreading spray with a solution of one tablespoonful of Qua Sul to one and a half gallons of water. Apply early before the disease starts if possible. In warm sections dust with sulphur. Water only in the morning.

\section{SHRUBBERY AND ROSES}

For the control of aphis, chewing insects, fungoid diseases use twelve level tablespoonfuls of All Round Spray to one gallon of water. Nico Garden Dust is also recommended.

For the control of Mealy Bug and Scale spray with a solution of one quarter pint Volck to one gallon of water; or Evergreen using 9 level teaspoonfuls to one gallon of water.

\section{VEGETABLES AND FLOWERS}

APHIS (Green or Black Fly) - Apply "Black 40" nicotine, Evergreen or Nicotine Miscible Oil.

CUT WORMS-Mix one pound of Paris Green in ten pounds of bran. Add one quart black strap molasses and two lemons chopped fine. Mix the whole to a crumbly mass and scatter on the ground. Snarol is also recommended, see page 93 .

GRASS HOPPERS-Same as for cut worms.

GREEN WORMS-On cabbage and cauliflower. Dust with Ham. mond's Slug Shot or spray with Evergreen.

MILDEW ON PEAS AND GRAPES-Apply Qua Sul or Sulphur as recommended for roses.

RUST-On Hollyhock and Snapdragon. Commence spraying when plants are young and repeat at intervals with a solution of eight level tablespoonfuls of Bordeaux Mixture to each gallon of water or spray with a solution of one tablespoonful of Qua Sul to one and a half gallons of water.

SLUGS AND SNAIIS-Scatter Snarol around the plants. Hydrated Lime is also recommended but loses its effectiveness as soon as it becomes damp. Apply the lime a few hours after watering and in the evening when these pests commence to appear.

SOW BUGS-Slices of raw potatoes, carrots or other vegetables rolled in Paris Green and placed in the haunts of this pest will prove effective. Snarol is also recommended, see page 93 .

TOMATO WORMS-As soon as worms appear, spray with a solution of three to four level tablespoonfuls of Dry Arsenate of Lead to each gallon of water. Evergreen is also recommended. 


\title{
The Way to Kill Ants, Snails, Slugs and Sow Bugs
}

\author{
ANTROL for Ants; SNAROL for Snails, Slugs, Sow Bugs, Cutworms and Gophers
}

\section{Ants Destroyed in their Nests NEW METHOD "GETS” THEM AT THEIR SOURCE- SAFE, PERMANENT, EFFECTIVE.}

The Antrol system is adapted to any size house or garden and destroys all species of sweet eating ants. It is composed of small glass containers and a special formula of syrup. The containers are partially filled with syrup and placed about the outside edges of the house or along "ant" trails in the garden if the infestation occurs there. The ants smell the syrup, eat it and then transmit its mild poison to the queen in the nest. Soon the entire ant colony is destroyed

The complete system should cover every 15 feet around the outside of the house or "ant" trails in the garden.

Antrol sets containing 4 containers and $14-$ oz. bottle of syrup. $\$ 1.00$. Cottage set, complete with 9 containers and syrup \$1.75. Antrol extra containers (each), 15c; Antrol syrup, 4-oz. bottle, 45c; pint, 75c; quart, \$1.25; gallon can, $\$ 3.00$. (Unmailable.)

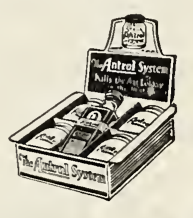

\section{Quickly Kills Garden Pests} SCIENCE PROVIDES NEW, SAFE METHOD THAT DOES THE WORK WITHOUT FUSS

Snails, Slugs, Cutworms, Grasshoppers, Sow Bugs, Earwigs, Gophers, Etc., Are Exterminated.

Snarol is a ready prepared meal that you simply broadcast on the ground, under the vegetation. The pests eat the meal and are quickly destroyed.

Snarol will not deteriorate from rain or sprinkling and also is non-injurious to vegetation when used according to simple directions. These features distinguish it from ordinary controls and make Snarol popular with professional gardeners and nursery men. $1 \mathrm{lb}$. package, $40 \mathrm{c} ; 3 \mathrm{lb}$. package, $85 \mathrm{c}$; $15 \mathrm{lb}$. bag, $\$ 3.25$; $50 \mathrm{lb}$. bag, \$8.50. (Unmailable.)

\section{Garden Tools and Requisites}

PRICES SUBJECT TO CHANGE WITHOUT NOTICE

(Articles marked postpaid are delivered free within the third zone)

BAMBOO CANES -3 feet, dozen, 20c; 100, $\$ 1.00 ; 4$ feet, dozen, $25 \mathrm{c}$; 100, \$1.50; 5 feet, dozen, 30c; 100, \$1.85; 6 feet, dozen, $40 \mathrm{c} ; 100, \$ 2.25 ; 7$ feet, dozen, $50 \mathrm{c} ; 100, \$ 3.00$.

BAMBOO CANES-Green stained for pot plants. 2 feet. $75 \mathrm{c}$ per $100 ; \$ 6.00$ per 1000 . Green stained, 3 feet, $85 \mathrm{c}$ per $100 ; \$ 7.00$ per 1000.

GARDEN STAKES-Heavy, square, painted green; made of redwood and impossible to rot. 3 feet, $\$ 1.25$ dozen; 4 feet, $\$ 1.50$ dozen; 5 feet, $\$ \mathbf{2} .00$ dozen; 6 feet, $\$ 2.50$ dozen; 7 feet, $\mathbf{3 5 c}$ each; $\$ 3.50$ dozen; 8 feet, $45 \mathrm{c}$ each, $\$ 4.50$ dozen.

Canes and Stakes F. O. B. San Francisco.

\section{Bellows and Dusters}

POWDER BELLOWS-Capacity one quart, $\$ 3.75$; postpaid $\$ 3.90$ BROWN'S NO. 1 DUSTER -50c each; postpaid, 60c.

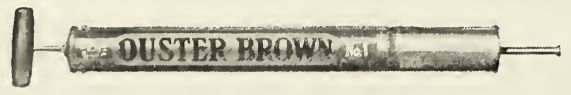

Brown's No. 1 Powder Duster

\section{Books, Horticultural}

CALIFORNIA FRUITS AND HOW TO GROW THEM-COM. plete on fruits, nuts and berries. By Prof. E. J. Wickson. (Weight $23 / 4$ pounds.) $\$ 4.00$.

CAIIFORNIA VEGETABLES IN GARDEN AND FIELD-By Prof. E. J. Wickson. (Weight 1 1 $\frac{1}{2}$ pounds.) \$2.50.

CALIFORNIA GARDEN FLOWERS-By Prof. E. J. Wickson. (Weight $11 / 4$ pounds.) $\$ 2.00$.

WIID FLOWERS OF CALIFORNIA-By Mary S. Parsons and Margaret W. Buck. (Weight $1 \frac{1}{2}$ pounds.) $\$ 4.00$.

\section{Flower Pots, Fern Dishes and Seed Pans}

The prices on these are all the same. Fern dishes are about two-thirds as deep as Flower Pots, and Seed Pans are one-third.

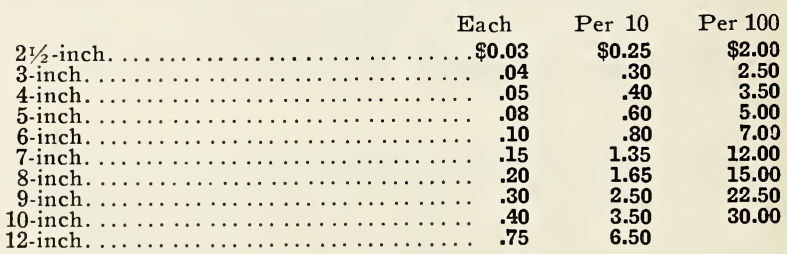

\section{SAUCERS FOR FLOWER POTS}

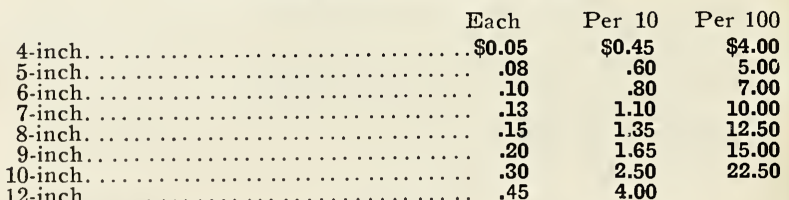

Packing extra, at actual cost. Shipped at owner's risk.

\section{PAPER FLOWER POTS}

Neponset. Just the thing to start your plants in. Will not break in sending. Ship nested together.

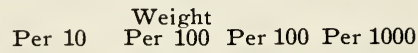

\begin{tabular}{|c|c|c|c|c|}
\hline $\begin{array}{l}21 / 2 \text {-inch. } \\
3 \text {-inch.... } \\
4 \text {-inch. } . . \\
5 \text {-inch. } . \\
6 \text {-inch. . }\end{array}$ & $\begin{array}{r}\$ 0.10 \\
. \quad .15 \\
. \quad .20 \\
. \quad .25 \\
. \quad .35\end{array}$ & $\begin{array}{ll}1 \mathrm{x} / 2 & \text { lbs. } \\
2 \mathrm{l} / 2 & \text { lbs. } \\
4 & \text { lbs. } \\
6 \mathrm{x} / 2 & \text { lbs. } \\
8 \mathrm{~L} / 2 & \text { lbs. }\end{array}$ & $\begin{array}{r}\$ 0.75 \\
1.00 \\
1.50 \\
2.25 \\
3.00\end{array}$ & $\begin{array}{r}\$ 6.00 \\
8.25 \\
13.50 \\
20.00 \\
27.00\end{array}$ \\
\hline
\end{tabular}

(If wanted by mail, add postage according to weights given above)

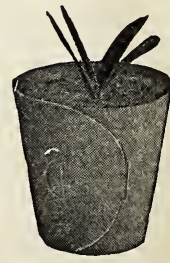


PRICES SUBJECT TO CHANGE WITHOUT NOTICE

\section{Fertilizers}

F. O. B. San Francisco

(If small quantities are wanted by parcel post, add postage)

ADCO-By the use of Adco all kinds of non-woody vegetable refuse, such as stalks, cuttings, withered leaves and flowers, potato, bean and pea vines, cabbage leaves and stalks, etc., can be converted into artificial manure. The refuse should be arranged in layers, each layer being thoroughly saturated with water and then sprinkled with Adco in the proportion of $2 \mathrm{lbs}$. Adco to every $50 \mathrm{lb}$. barrow load of refuse. 25 lbs., $\$ 2.25$; 150 lbs., \$11.00. (Pamphlet with directions how to use, mailed on request).

PURE GROUND BLOOD AND BONE MFAI-Fine pulverized; excellent for rose-culture. It decomposes very rapidly and is more quickly effective than the coarser grades. It is excellent for mixing with the soil for potting. Use 1 teacupful for a rose bush or apply at the rate of 5 lbs. per 100 square feet. 3 lbs., $25 \mathrm{c}$; 10 lbs., $75 \mathrm{c}$; 25 lbs., $\$ 1.50$; 50 lbs., $\$ 2.75$; 100 lbs., $\$ 5$.

BONE MEAI_Finely ground; an excellent fertilizer for all garden purposes. Should be forked into the ground in the Fall if pos-
sible. 5 lbs. $35 \mathrm{c}$; 10 lbs., 60c; 25 lbs., $\$ 1.25$; 50 lbs., $\$ 2.25$; sible. 5 lbs., 35
100 lbs., $\$ 4.00$.

BLOOD MEAL_A very quick acting fertilizer and also extensively used for spraying on trees to keep off deer. $2 \mathrm{lbs}$. for $25 \mathrm{c}$; 10 lbs., 90c; 25 lbs., $\$ 1.85$; 50 lbs., $\$ 3.50 ; 100$ lbs., $\$ 6.50$.

FIORANID-The best nitrogen fertilizer; contains $46 \%$ nitrogen. $1 \mathrm{lb}$. cans, $65 \mathrm{c}$ ( $75 \mathrm{c}$ postpaid). Booklet with directions how to use, mailed on request.

GROMORE-A highly concentrated fertilizer. Booklet with directions how to use, mailed on request. 2 lbs., $50 \mathrm{c}$; 5 lbs., $\$ 1.00$; 25 lbs., $\$ 3.00$; 125 lbs., $\$ 10.50$.

HUMTS OR CAIIFORNIA PEAT-Good for mixing with soils. Sack, $\$ 1.25 ; 5$ sacks, for $\$ 5.50 ; 10$ sacks, $\$ 10.00$.

IIME, "Agricultural"-An organic shell flour for lightening and sweetening soils. Apply at the rate of $100 \mathrm{lbs}$, per 500 square feet. In $100 \mathrm{lb}$. sacks only. $\$ 1.50$.

NITRATE OF SODA-Especially stimulates the growth of the foliage, stems and roots of plants. Should be administered to growing plants only, at the rate of $1 \mathrm{lb}$. per 250 square feet, re peated at intervals of 2 or 3 weeks. $10 \mathrm{c}$ per lb.; $10 \mathrm{lbs}$., $75 \mathrm{c} ; 25$ lbs., $\$ 1.50$; 100 lbs., $\$ 5.00$. (Unmailable as combustible.)

NITROPHOSKA-A highly concentrated, complete fertilizer, almost entirely soluble in water and completely available. $1 \mathrm{lb}$. can, 50 c (60c postpaid). Booklet with directions how to use on request.

PEAT-(HOLIAND)-For building up soils. 1 lb., 15c; $101 \mathrm{bs}$., $\$ 1.00$; 25 lbs., $\$ 1.75$; compressed bale $18 \times 28 \times 36$ ins., $\$ 5.00$. One bale will cover 240 square feet, 1 inch thick.

PUIVERIZED SHEEP IMANURE, "GROZ-IT" BRAND-5-1b. pkg., 25c; 10-1b. pkg., 45c; 25-lb. sack, 75c; 50-1b. sack, \$1.25; $100-1 b$. sack, $\$ 2.25 ; 5$ sacks, $\$ 10 ; 10$ sacks, $\$ 17.50$.

SULPHATE OF AMMONIA-A nitrogenous fertilizer similar in its effects to Nitrate of Soda but is slower in action and is retained by the soil. Apply at the rate of $11 \mathrm{~b}$. per 250 square feet. 3 lbs. for 25c; 10 lbs., 75c; 25 lbs., \$1.35; 50 lbs., \$2.65; 100 lbs., $\$ 5.00$.

SUPERPHOSPHATE-Has the opposite effect to the nitrogenous fertilizers, checking rank growth and encouraging the early formation of flowers, fruit and seeds. Apply at the rate of 2 or 3 lbs. per 250 square feet. $4 \mathrm{lbs}$., $25 \mathrm{c}$; $10 \mathrm{lbs}$., $50 \mathrm{c}$; $25 \mathrm{lbs}$., S1.00; 50 lbs., s1.75; 100 lbs., $\$ 3.00$.

STIM-U-GERM - A nitrogen gathering bacteria for inoculating sweet peas, garden peas and beans, garden size, 25c (postpaid).

STIM-U-PLANT-A concentrated fertilizer in tablet form. Guaranteed analysis of $11 \%$ nitrogen, $12 \%$ phosphoric acid and $15 \%$ potash. Full directions with each package. 30 tablets, $25 \mathrm{c} ; 100$ tablets, 75c; 1000 tablets, $\$ 3.50$; (postpaid).

TOBACCO BASE FERTIIIZER “ $\boldsymbol{F}$ \& I"-A fertilizer and insecticide which has a nicotine content of $1.00 \%$ and contains Nitrogen, Phosphoric Acid, Ammonia and Potash. It is applied both by working into the soil or as a top dressing. $100 \mathrm{lb}$. sack, \$4.25.

\section{Garden Tools}

COMBINATION HOE \& RAKE-4-tine, $\$ 1.25$ each; 6-tine $\$ 1.50$ each, F. O. B.

COMBINATION SET-Consisting of Ladies' Floral Spade, Ladies' Hoe and Ladies' Steel Rake. \$2.50 F. O. B.

CORN PLANTER ACME-\$1.25 each (postpaid, \$1.40).

CULTIVATOR NORCROSS - 5 prong, long handle. $\$ 1.25$ each, F. O. B.; 3 prong, long handle, $\$ 1.00$ each, F. O. B.; 3 prong, short handle, $65 \mathrm{c}$ each ( $75 \mathrm{c}$ postpaid).

FORKS-True temper, spading, heavy-weight, strapped long or D handle. $\$ 2.25$ each, F. O. B.

FORK_Ladies' Floral, $\$ 1.25$ each, F. O. B.

HAND FORK-Weight 10 oz. 60c each; 65c postpaid.

HOES-True temper, $\$ 1.25$ each, F. O. B.

HOES-Ladies' Steel. 90c each, F. O. B.

RAKES-True temper, Steel, 12-tine, \$1.15; 14-tine, \$1.25; 16-tine, \$1.35, F. O. B.

RAKES, BAMBOO-Reinforced, 50c each, F. O. B.

RAKES-Park Lawn, $\$ 2.60$ each F. O. B.

RAKES-Ladies' Steel, 6-tine, 65c each F. O. B.

SHOVELS-Round or square point. smooth back. Stanler, \$1.75 each; Carter, $\$ 2.25$ each, F. O. B.

SHOVELS-Ladies' Floral, \$1.10 each, F. O. B.

SPADES-Long and D handle, smooth back. Stanley, \$1.75 each; Carter, $\$ 2.25$ each, F. O. B.

THERMOMETFRS-Self registering, indicates maximum and minimum degrees of temperature, Boxwood back. $\$ 2.50$ each; $\$ 2.60$ postpaid.

TROWELS $25 \mathrm{c}, 50 \mathrm{c}$ and $85 \mathrm{c}$ each. Transplanting, narrow blade, $25 \mathrm{c}$ each. Postage $5 \mathrm{c}$ extra.

Maynard Pattern-95c each; $\$ 1.00$ postpaid.

WATERING POTS, WOTHERSPOON'S-Oval, galvanized iron with brass fittings and two brass roses, one fine and one coarse, with each pot. (These are hard to pack and are better sent by express than by mail.) 6-quart, $\$ 5.50$; 8-quart, $\$ 6.00$; 10 -quart, \$6.50.

WEEDERS-Dandelion, 50c each; 55c postpaid.

\section{Gopher and Mole Exterminators}

GOPHER TRAP MACABEE-25c each; 30c postpaid.

"NEVER FAII" GOPHER GUN-Positive destruction of gophers, moles and other burrowing pests. Each, $\$ 2.00$ postpaid.

BLANK CARTRIDGES FOR ABOVE-25c per dozen; box of 50 , 85c. (Unmailable.)

"DOUBLE CATCH" GOPHER TRAP -50 c each (60c postpaid).

GAS BAILS-For killing gophers, squirrels and other rodents. I dozen, 35c; 3 dozen for $\$ 1.00$; carton of 125 for $\$ 2.75$. (Postpaid within 3rd zone.)

o. k. GOPHER POISON-Poisoned raisins and grain for destroying gophers, squirrels and other rodents. 6 oz. pkg., $35 \mathrm{c}$; 1 lb. pkg., 60c. (Unmailable.)

\section{THE "GOPHER GETTER"}

By use of this GOPHER GET. TER with Carbon Bisulphide the destruction of all ground pests in the garden, orchard and field is absolutely sure. There is no known method better than the use of Carbon Bisulphide because it reaches all life in the burrow.

Pamphlet with full directions for using enclosed with each order or mailed free on request. $\$ 2.00$ each (postpaid \$2.10.)

CARBON BISULPHIDE - $1 \mathrm{lb}$. cans, 35c; 10 lbs., $\$ 2.00$. (Un. mailable.)

\section{MOLE TRAPS}

SCHROETER'S IMPROVED The best mole trap with patented self-setting attachment. $\$ 1.75$ each (postpaid \$1.90.)

REDDICK- $\$ 1.50$ each (postpaid \$1.65).

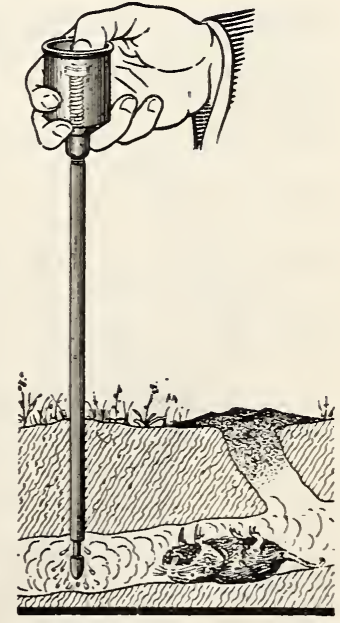

The "Gopher Getter" 


\section{PRICES SUBJECT TO CHANGE WITHOUT NOTICE}

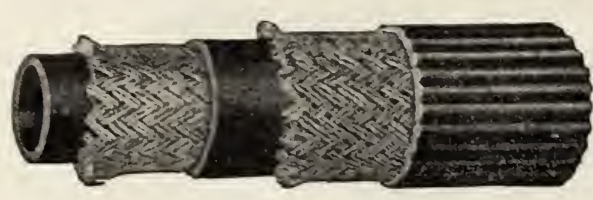

Hose Rubber

(F. O. B. San Francisco)

ELECTRIC-Corrugated $\mathrm{I} / 2$ inch in 25 and 50 foot lengths at $20 \mathrm{c}$ per foot. 34 inch in 25 and 50 foot lengths at $22 \mathrm{c}$ per foot.

WEARSO-Ribbed $\mathrm{r} / 2$ inch in 25 and 50 -foot lengths at $13 \mathrm{c}$ per foot. $3 / 4$ inch in 25 and 50 -foot lengths at $15 \mathrm{c}$ per foot.

HIPPO- $3 / 4$ inch in 25 and 50 -foot lengths at $20 \mathrm{c}$ per foot.

RUBRO RED HOSE-Ribbed $1 / 2$ inch in 25 and 50 -foot lengths at

$14 \mathrm{c}$ per foot. $3 / 4$ inch in 25 and 50 -foot lengths at $16 \mathrm{c}$ per foot.

\section{Hose Accessories}

HOSE COUPLING "CIINCH"-Brass, $1 / 2$ and $3 / 4$ in., $25 \mathrm{c}$ per pair; 30c postpaid.

HOSE MENDER, CLINCH_Price, 2 for 25c; $\$ 1.35$ per dozen, for $1 / 2$ and $3 / 4$ inch hose. $\$ 1.45$ per dozen, postpaid.

BOSTON HOSE NOZZLE-Adjustable coarse or fine spray. 85c each; 90c postpaid.

BRASS ROSE-75c each, postpaid.

ROSS-Fan shaped; very fine spray. $85 \mathrm{c}$ each; $90 \mathrm{c}$ postpaid.

"SECURE" HOSE WASHERS-20c per dozen.

\section{Labels, Wooden}

For trees, pots and gardens

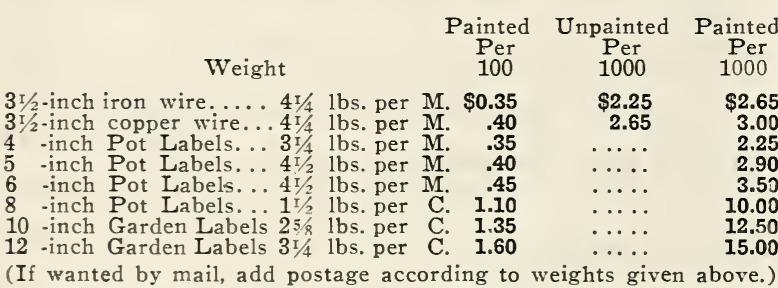

COPPER-Wired for trees, $3 \mathrm{r} / 2$ inch; marking is done with a stylus, furnished free with each hundred. Per dozen, 30c; per 100, $\$ 1.75$.

\section{Miscellaneous}

GRAFTING WAX_-"Mapco." I/4 lb., 20c; I/2 lb., 35c; lb., 60c. Postage 5c per package extra.

GRAPrING WAX_Snow's, in bricks, black. Lb., 50c; 4 lbs., \$1.75; Postage extra.

MOSS SELECT SPHAGNUM-Lb., 20c; 10-1b. sack, \$1.50. Postage extra. Special prices for larger lots.

MOSS, GREEN-Lb., 20c; 10-1b. sack, \$1.50. Postage extra. Special prices for larger lots.

PRUNING COMPOUND, PABCO-For use after pruning, pint, $35 \mathrm{c}$; postpaid, $40 \mathrm{c}$; quart, $55 \mathrm{c}$; postpaid, $65 \mathrm{c}$.

RAFFIA_Largely used by nurserymen and others and considered the best and cheapest material for tying known. 50c per lb; $\$ 4.50$ per 10 lbs.; postage extra.

TREE PROTECTORS, "YUCCA"-A perfect protection for young trees against rabbits, grasshoppers, sunburn, frost, etc. The usual size is 7 inches wide and of various lengths.

\begin{tabular}{|c|c|c|c|c|}
\hline & $\begin{array}{l}\text { Weight } \\
\text { Per } 100\end{array}$ & $\begin{array}{c}\text { Per } \\
50\end{array}$ & $\begin{array}{c}\text { Per } \\
100\end{array}$ & $\begin{array}{c}\text { Per } \\
1000\end{array}$ \\
\hline $\begin{array}{l}12 \text {-inch. } \\
16 \text {-inch. } \\
18 \text {-inch. } \\
24 \text {-inch. }\end{array}$ & $\begin{array}{l}.8 \mathrm{~s} / \mathrm{lb} . \\
.12 \mathrm{lb} . \\
13 \mathrm{lb} . \\
.19 \mathrm{lb} .\end{array}$ & $\begin{array}{r}\$ 0.75 \\
.90 \\
.95 \\
1.15\end{array}$ & $\begin{array}{r}\$ 1.30 \\
1.5 \\
170 \\
2.10\end{array}$ & $\begin{array}{r}\$ 11.75 \\
14.0 n \\
15.50 \\
19.00\end{array}$ \\
\hline
\end{tabular}

(If wanted by mail, please add postage; weights as given above.)

VINE STAPIES-Coppered. lb. pkg., 35c. Postage extra.

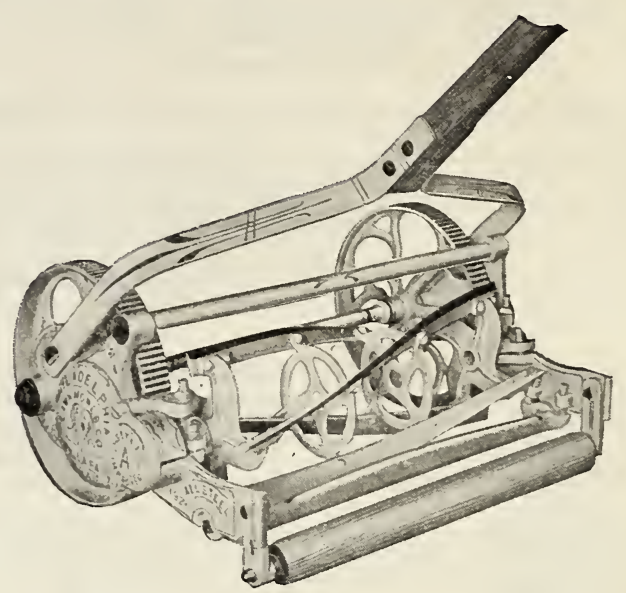

Philadelphia Style A-Improved Lawn Mower

\section{Lawn Mowers}

BABY GRAND-Light and easy running. A smaller ball-bearing mower that would give better satisfaction could not be built. Every bearing is accurately machined and all material carefully selected. Four revolving blades of high grade crucible steel, oil tempered and water ground. All ball-bearings a re automatically adjusted. Drive wheels, $8 \mathrm{1} / 2$ inches; reel, $5 \mathrm{I} / 2$ inches diameter. 12-inch, \$10.50; 14-inch, \$11.00; 16-inch, \$11.50. (Parts kept in stock).

PHILADELPHIA, STYLE K-Has 5 blades, part steel, single pinion, a high class mower. 14 -inch, $\$ 20.00$; 16 -inch, $\$ 22.00 ; 18$ inch, $\$ 24.00$.

PHILADELPHIA STYLE A-Improved. This new mower has re. movable box caps for taking the cylinder out without disturbing the frame or adjustments. This mower meets the most exacting demands and it is a fact that there are more style " $A$ " all steel mowers cutting grass in public and private parks, cemeteries and golf links than all other makes combined. Being all steel it is practically indestructible. It has self-oiling cups lasting for five hours' continuous use and Vanaddium Crucible steel blades. 15 -inch, $\$ 27.00 ; 17$-inch, $\$ 30.00$.

IMPERIAI ROLLER BEARING-16-inch, \$22.50; 18-inch, \$24.00. IAWN TRIMMER-Ace, $\$ 12.50$ each.

GRASS CATCHERS-Adjustable for 12 -inch to 16 -inch mowers. "Non-Slip" bottom, $\$ 1.75$ each, F. O. B.

\section{Shears and Pruners}

PRUNING SHEARS-NAPA NO. 7-9-inch, per pair, $\$ 1.25$ postpaid.

NAPA No. 6-9-inch, per pair, $\$ 2.00$ postpaid.

NAPA No. 5, EXTRA STRONG SPRING-9-inch, per pair, \$2.50 postpaid.

NAPA, No. 4, HEAVY - 9-inch, per pair, \$3.25 postpaid.

NAPA, No. 2, EXTRA HEAVY-9-inch, per pair, $\$ 4.50$ postpaid. GENUINE REISER-Per pair, $\$ 5.00$ postpaid.

IADIES' SMALI NICKEL FLOWER SHEARS $-4 \frac{1}{2}$ inch, per pair, $\$ 1.50$ postpaid.

BORDER SHEARS- $\$ 5.25$ per pair, F. O. B.

GRASS or SHEEP SHEARS-Per pair, $75 c$. $\$ 1.25$ and $\$ 1.75$ according to grade, postpaid.

HEDGE SHEARS-Hand-forged 6-inch blade, per pair, \$1.75: 8 inch blade, $\$ 3.00 ; 9$-inch blade, $\$ 3.25 ; 10$-inch blade, $\$ 3.75$. Postage 15c per pair extra.

TREE PRUNING SHFARS-Cartwright. 26 inch handle, $\$ 3.50$ each;; 29 inch handle, $\$ 3.75$ each, F. O. B.

TRED PRUNERS 6 feet, $\$ 2.00$ each; 8 feet, $\$ 2.25$ each; 10 feet, $\$ 2.50$ each, F. O. B.

PRUNING and BUDDING KNIVES-In full assortment. 
PRICES SUBJECT TO CHANGE WITHOUT NOTICE

\section{Sprinklers, Lawn}

FAN SPRINRIER-Shaped so that it waters a bed on one side only. $35 \mathrm{c}$ each; $40 \mathrm{c}$ postpaid.

TWIN SPRINKLER-Will cover the lawn evenly for 16 feet radius. $40 \mathrm{c}$ each; $45 \mathrm{c}$ postpaid.

No. 75 SPRINKLER-White metal; throws a large spray, 50c postpaid.

No. 101 SHOWER_Small fountain sprinkler. 50c each; postpaid.

GOLDEN GATE SPRINKIER (Borgeson's)-Throws a lowspreading spray. $\$ 1.50$ each; $\$ 1.60$ postpaid.

\section{Sprayers}

BROWN'S NO. 3G WHEELBARROW SPRAYER-Compressed air tank. Capacity 15 gallons. Galvanized steel. Adaptable for white-washing, tree and garden spraying. \$35.00.

TIN SPRAYER-For spraying liquid insecticides of all kinds on plants, kerosene in chicken houses, etc. An all-round useful instrument and at a low price. $50 \mathrm{c}$ each; $60 \mathrm{c}$ postpaid.

\section{It Sprays Continuously}

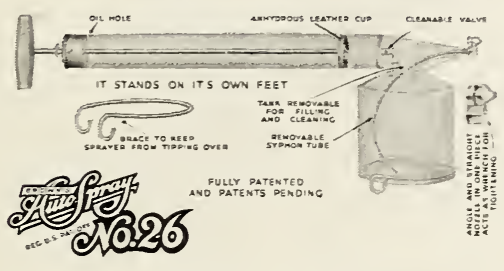

Brown's Continuous Sprayer, No. 26

BROWN'S CONTIIUUOUS SPRAYER, No. 26B, BRASS RESERVOIR and TIN PUMP - Throws spray uninterruptedly by a few strokes. \$1.25 each; postpaid \$1.35.

BROWN'S CONTINUOUS SPRAYER, No. 26C-Same as the preceding excepting that it is all brass. $\$ 1.50$ each; $\$ 1.60$ postpaid.

BROWN'S No. 43 GLASS SPRAYER-A good sprayer for small garden use having a glass jar which can be easily taken off and tubes cleaned. $85 \mathrm{c}$ each; $\$ 1,00$ postpaid.

RUBRER PLANT SPRINKLERS, "SCOLLAY'S"-For indoor watering, straight neck. $\$ 1.40$ each; $\$ 1.50$ postpaid.

\section{Brown's Bucket Pump No. 60}

BROWN'S BUCKET PUMP No. 60-A high powered bucket pump. $\$ 5.50$ postpaid within 2nd zone.

"EASTERN" GARDEN WHEELBARROW-We guarantee these barrows to be better made and more neatly finished than any other garden barrow on the market. Made entirely of hardwood. Iron leg braces are thoroughly bolted, not held by screws, making these barrows "custom" barrows.

No. 2-Small ladies' or boys'. $\$ 6.00$.

No. 3-Capacity, 3 cubic feet. $\$ 7.50$.

No. 4-Capacity, 4 cubic feet. $\$ 8.50$.

No. 5-Capacity, 5 cubic feet. $\$ 9.00$.

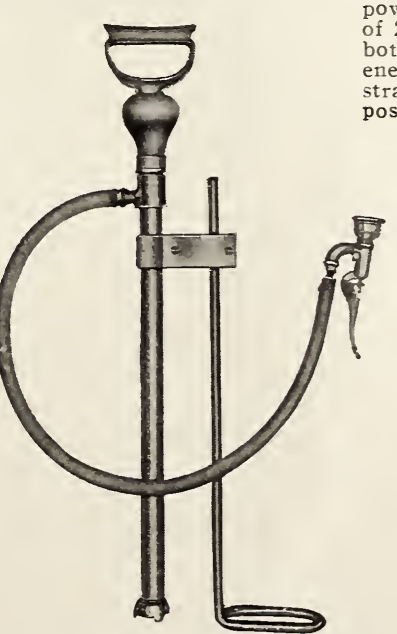

Brown's Bucket Pump, No. 60

\section{Brown's Auto Spray No. 9}

Strong, simple compressed air sprayer of modern construction. Equipped with a brass screw cap. The metal in the tank is lock seamed, well riveted. soldered inside and out. May be obtained with brass or galvanized tank. Brass tank is strongly recom. mended as it will not corrode. Capacity $3 \frac{1}{2}$ gallons, height 2 feet. diameter 7 inches, we igh t empty, 9 pounds.

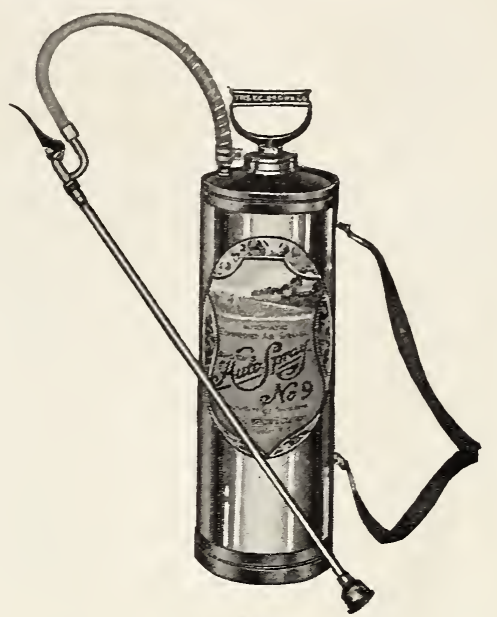

AUTO-SPRAY No. 9D-Galvanized tank. $\$ 6.50$ postpaid, within 2nd zone.

AUTO-SPRAY No. 9B-Brass tank. $\$ 9.50$ postpaid within 2nd zone. Extra parts kept in stock.

Brown's Auto-Spray No. 5

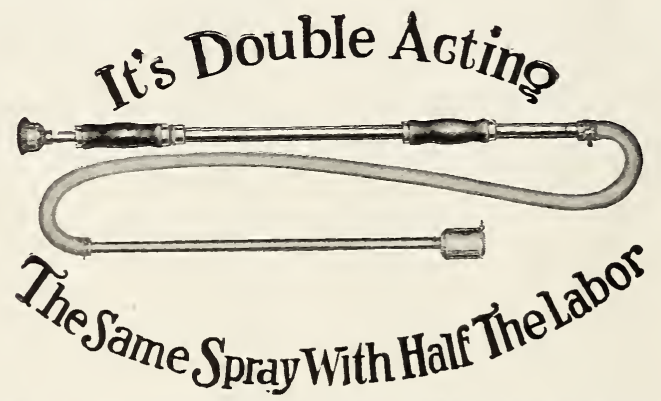

THE DOUBLE ACTION HIGH-PRESSURE SPRAYER

Use with any pail or bucket

AUTO-SPRAY NO. 5 is generally acknowledged to be the most powerful pump of this type manufactured, generates a pressure of 200 lbs. with remarkable ease. Throws continuous sprays on both the up and down strokes and requires about one half the energy of other pumps of this type. Suction end containing strainer, is weighted and will not work out of bucket. $\$ 5.00$ postpaid within 2 nd zone.

\section{Brown's Auto Spray No. 50}

This sturdy little machine is almost identical to Auto Spray No. 9 in construction and manipulation, but has half the capacity, holding about two gallons. It is particularly recommended for use where weight is a factor.

No. 50D-Galvanized, $\$ 5.50$ postpaid within $2 \mathrm{nd}$ zone.

No. 50B-Brass. $\$ 7.50$ postpaid within 2 nd zone.

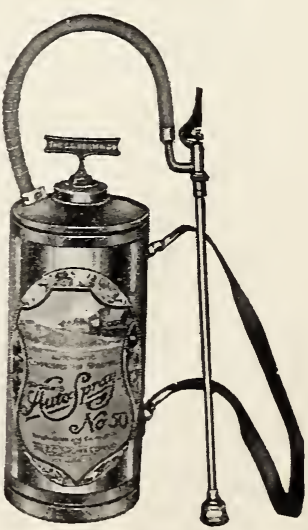




\section{VEGETABLE, TREE AND GRASS SEEDS AND HORTICULTURAL REQUISITES}

Directions tor planting Vegetables, Pages 1-6. Seasons to Sow Vegetable Seeds, Inside of Front Cover.

Page

Antrol $\ldots \ldots \ldots \ldots \ldots . . .62$

Artichoke ............... 7

Asparagus.$\cdots \cdots \cdots \cdots \cdots{ }_{95}^{7}$

Auto Spray $\ldots \ldots \ldots \ldots .99$

Bamboo Canes ........ 92

Beet ..................., 9

Bird Seeds.$\ldots \ldots \ldots \ldots .22$

Books $\ldots \ldots \ldots \ldots \ldots .92$

Brussels Sprouts

Cabbage .............. 10

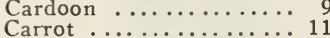

Carrot $\ldots . . . \ldots \ldots \ldots \ldots . . .11$

Celery..$\ldots \ldots \ldots \ldots \ldots .12$

Celeriac $\ldots \ldots \ldots \ldots \ldots$. 12

Chicory $. . . \ldots \ldots \ldots \ldots . . .69$

Chives .............22

Collard...$\cdots \cdots \cdots \cdots \cdots \cdots$

Corn Salad ............ 12

Cucumber
Cress
Page

Dandelion .......... 13

Egg Plant .......... 13

Fertilizers ......... 93

Field Seeds ........... 23

Garlic .............. 16

Gopher Exterminators .. 93

Grass Shears ............. 94

Grass Seeds $\quad . \ldots \ldots \ldots 22,23$

Hedge Shears ........ 94

Herbs ............. 22

Herb Plants $\ldots \ldots \ldots \ldots \ldots 22$

Horse Radish ........ 22

Hose Hoze $_{\text {Holes } \ldots \ldots \ldots \ldots . . .} 94$

Humus .............. 93

Insecticides ......90, 91

Kale...$\ldots \ldots \ldots \ldots \ldots 13$

Kohl Rabi ................ 13

Lawn Grasses ........ 22

Lawn Mowers $\ldots \ldots \ldots \ldots 94$
Page

Leek .............. 13

Lettuce $\ldots . . . \ldots \ldots \ldots . . .14$

Mangel ............. 9

Mole Exterminators .... 93

Moss .............. 94

Mushroom Spawn ........ 13

Muskmelon $\ldots \ldots \ldots \ldots 14,15$
Mustard $\ldots \ldots \ldots \ldots \ldots, 14$

Onion ............. 16

Onion Sets $\ldots \ldots \ldots \ldots \ldots$
Okra $\ldots \ldots \ldots \ldots \ldots \ldots$

Paper Pots ......... 92

Parsley..$\ldots \ldots \ldots \ldots \ldots 18$

Parsnip $\ldots \ldots \ldots \ldots \ldots \ldots \ldots \ldots \ldots$
Peas.$\ldots \ldots \ldots \ldots \ldots .17$

Peat ............... 93

Pepper ................. 18

Potato ...............17

Pots $\dddot{3}$ Powder........... 92

Pruning Shears ....... 94

Pumpkin ............ 18

Radish ............. 19

Raffia $\ldots \ldots \ldots \ldots \ldots \ldots . .64$

Rhubarb ............ 19

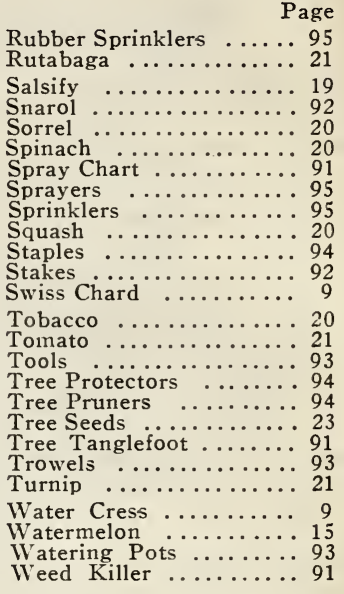

\section{FLOWER SEEDS}

Directions for Sowing Flower Seeds, Page 25. Seasons to Sow Flower Seeds, Pages 24-25. Classification of Flowers, Page 26

Page

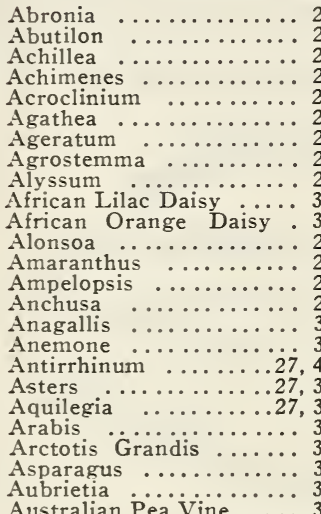

Australian Pea Vine.......

Baby Blue Eyes .......44

Bachelor's Buttons

Balloon Vine

Balsam Apple

Bartonia

Begonia

Bell

Blue Lace Flower

Blue Marguerite.

Boston Ivy

Brachycome

Browallia

Bush Eschscholtzia

Calceolaria

Calendula

California Poppy

Calliopsis

Campanula

Candy tuf

Canterbury Beil

Canna

Cape Marigold

Cardinal Climber

Carnation

Castor Beans

Celosia

Celsia

Centaurea

Cerastium

Chelone

Cheiranthus

Chinese Woolflowe

Chrysanthemum
Page

Cineraria

Clarkia .................. 34

Cleome $. . . \ldots \ldots \ldots \ldots \ldots . . .34$

Cobaea ............... 34

Cockscomb ............. 33

Coleus .............. 34

Collinsia $\ldots \ldots \ldots \ldots \ldots,{ }^{3}{ }_{34}^{34}$

Columbine $\ldots \ldots \ldots \ldots 27,35$

Convolvulus $\ldots \ldots \ldots \ldots \ldots{ }^{43}$

Cornflower ............. 33

Cosmos .............. 35

Cynoglossum $\cdots \cdots \cdots \cdots \cdots, 35$

Cypress Vine $\ldots \ldots \ldots \ldots .35$

Dahlia ............. 36

Daisy $\ldots \ldots \ldots \ldots \ldots \ldots, 27,45$

Dianthus ............27, 36

Diascia $\ldots \ldots \ldots \ldots \ldots \ldots . \ldots . \ldots 36$

Didiscus $\quad \ldots \ldots \ldots \ldots \ldots 36$

Digitalis $\ldots \ldots \ldots \ldots 28,37$

Dimorohotheca

Dolichos ............... 36

Eschscholtzia ........ 37

Euphorbia ........... 37

Evening Primrose $\ldots \ldots .44$

Everlasting Pea ....... 41

Forget-Me-Not $\ldots \ldots \ldots 37$

Four o'Clock ........ 37

Foxglove ............28, 37

Freesia ............... 37

Gaillardia $\ldots \ldots \ldots \ldots 28,37$

Gaura ............... 37

Geranium $. . . \ldots \ldots \ldots . . .37$

Gesnera $\ldots \ldots \ldots \ldots \ldots \ldots \ldots{ }_{38}^{38}$

Gilia $\ldots \ldots \ldots \ldots \ldots \ldots . . . \ldots$

Gloxinia $\quad \cdots \ldots \ldots \ldots .38$

Godetia $\ldots \ldots \ldots \ldots \ldots . . . \ldots \%$

Gomphrena ........... 38

Gourds $\ldots \ldots \ldots \ldots \ldots .39$

Gypsophila $\ldots \ldots \ldots \ldots . . .63$

Helichrysum ............. 39

Heliopsis .............. 39

Heliotrope......... .39

Hesperis $\ldots \ldots \ldots \ldots \ldots .6 \%$

Heuchera...$\ldots \ldots \ldots 39$

Hibiscus $. . . \ldots \ldots \ldots .3 . \cdots 39$

Honesty $. . . \cdots \cdots \cdots . . . .40$

Hop Jap ........... 4C

Humulus $\ldots \ldots \ldots \ldots \ldots{ }_{4 C}$

Hyacinth Bean $\ldots \ldots \ldots \ldots 36$
Page

Iberis $\ldots \ldots \ldots \ldots \ldots \ldots 32$

Impatiens $\ldots \ldots \ldots \ldots \ldots \ldots, 40$

Ipomoea $\ldots . . \ldots \ldots \ldots . .640$

Jacobea ............ 40

Kenilworth Ivy ......40

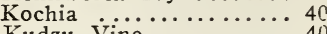

Kudzu Vine ............. 40

Larkspur ...........28, 41

Lathyrus $\ldots . \ldots \ldots \ldots . . .24$

Lavatera

Lavender ............... 41

Leptosyne $\ldots \ldots \ldots \ldots .41$

Lilium Regale $\ldots \ldots \ldots \ldots{ }^{28}$

Linum $\ldots \ldots \ldots \ldots \ldots \ldots \ldots \ldots .41$

Linum $\cdots \cdots \cdots \cdots \cdots \cdots, 41$

Love-in-a-mist $\ldots \ldots \ldots \ldots .44$

Lupin $\ldots \ldots \ldots \ldots \ldots \ldots 41$

Lychnis $\ldots \ldots \ldots \ldots \ldots{ }_{42}^{42}$

Mallow ........... 41

Marigold $\ldots \ldots \ldots \ldots .28,42$

Marvel of Peru ....... 37

Matricaria $\ldots \ldots \ldots \ldots \ldots 42$

Mathiola $\ldots \ldots \ldots \ldots \ldots \ldots 42$

Mignonette...$\ldots \ldots \ldots \ldots 42$

Mimulus ........... 43

Mimosa $\ldots \ldots \ldots \ldots \ldots{ }_{42}^{4}$

Mina Lobata ......... 42

Morning Glory ......... 43

Moonflower .......... 40

Musk $\ldots \ldots \ldots \ldots \ldots .43$

Myosotis $\ldots \ldots \ldots \ldots \ldots . .34$

Vemesia $\ldots . . . \ldots \ldots \ldots . .43$

Vemophila $\ldots \ldots \ldots \ldots \ldots 44$

Nicotiana ............. 44

Nigella ............... 44

Oenothera $\ldots \ldots \ldots \ldots . .44$

Pansy ............. 44

Pelargonium .......... 37

Pentstemon .......... 45

Petunia ............. 45

Phacelia .............. 45

Phlox $\ldots \ldots \ldots \ldots \ldots \ldots \ldots \ldots, 46$

Physostegia .......... 45

Pinks ............... 36

Platycodon ..........4 45

Polyanthus ...........4 46

Poppy $\ldots \ldots \ldots \ldots \ldots \ldots 28,46$
Page

Potentilla $\ldots \ldots \ldots \ldots .45$

Primrose $\ldots . \ldots \ldots \ldots .4 .46$

Pyrethrum $\ldots \ldots \ldots \ldots \ldots 464$

Rehmannia .........47

Reseda $\ldots \ldots \ldots \ldots \ldots \ldots$ 4 47

Ricinus $\ldots \ldots \ldots \ldots \ldots \ldots . \cdots \times 32$

Rudbeckia .............. 47

Ranunculus ...........4 47

Salpiglossis ........ 47

Salvia

Saponaria $\ldots \ldots \ldots \ldots \ldots, 47$

Sanvitalia $\ldots \ldots \ldots \ldots \ldots .6 \%$

Scabiosa $\ldots \ldots \ldots \ldots .28,48$

Scarlet Flax $\ldots \ldots \ldots \ldots \ldots 41$

Schizanthus ..........28, 48

Sensitive Plant .........442

Shasta Daisy ............ 35

Sidalcea $\ldots \ldots \ldots \ldots \ldots, 47$

Silene ............ 48

Snapdragon $\ldots \ldots \ldots \ldots 27,49$

Snapdragon $\ldots \ldots \ldots \ldots 27,49$

Solanum $\ldots \ldots \ldots \ldots \ldots .49$

Statice $\ldots \ldots \ldots \ldots \ldots \ldots .49$

Stocks $\ldots \ldots \ldots \ldots \ldots \ldots . .28,50$

Stokesia ............ 50

Streptocarpus ........ 49

Sunflower

Sweet Peas …........51, 52

Sweet Rocket ......... 50

Sweet Sultan .......... 33

Tagetes......... .53

Thalictrum $\ldots \ldots \ldots \ldots .53$

Thunbergia .......... 53

Tithonia .......... 53

Tobacco, Flowering .... 44

Torenia $\ldots \ldots \ldots \ldots \ldots 53$

Trachelium...$\cdots \ldots \ldots .53$

Tree Mallow .......... 41

Tufted Pansy $. . . \ldots \ldots . .644$

Verbascum $\cdots \ldots \ldots \ldots \ldots . . .653$

Verbena $. . \cdots \cdots \ldots . . .55$

Veronica $\ldots \ldots \ldots \ldots \ldots \ldots .6 .65$

Vinca ............. 53

Viscaria $\ldots \ldots \ldots \ldots \ldots \ldots .53$

Viola .............. 44

Virginia Stock .......... 53

Wallflower .......... 53

Wild Flowers .......... 53

Xeranthemum ....... 54

Zanzibar Balsam ........ 40 
TREES, PLANTS, SHRUBS AND BULBS

Page

Abelia $\ldots \ldots \ldots \ldots \ldots .62$

Abies $\ldots \ldots \ldots \ldots \ldots \ldots \ldots 6606060$

Acacia $\ldots \ldots \ldots \ldots \ldots \ldots \ldots 66 \% 62$

Acanthus $\ldots \ldots \ldots \ldots \ldots \ldots, 78$

Achillea $\ldots \ldots \ldots \ldots \ldots 78$

Agapanthus $\ldots \ldots \ldots \ldots \ldots 78$

Agapanthus $\ldots \ldots \ldots \ldots \ldots, 78$

Ajuga
Almond, Flowering $\ldots \ldots$

Almond, Fruiting ...... 87

Alyssum.$\ldots \ldots \ldots \ldots \ldots 78$

Ampelopsis $\ldots \ldots \ldots \ldots \ldots .71$

Anchusa $. . . \ldots \ldots \ldots, 78$

Anemone $\ldots \ldots \ldots \ldots \ldots .78$

Apricot, Fruiting $\ldots \ldots \ldots 86$

Aquilegia $\ldots \ldots \ldots \ldots \ldots 78$

Arabis $1 \ldots \ldots \ldots \ldots \ldots \ldots$ 78

Arbor vitae $\ldots \ldots \ldots \ldots \ldots, 62$

Arenaria $\quad \cdots \ldots \ldots \ldots \ldots \ldots \ldots$ \% 79

Armeria Asters, Hardy $\ldots \ldots \ldots \ldots 78$

Aubrietia $\ldots \ldots \ldots \ldots \ldots .79$

Aucuba $\ldots \ldots \ldots \ldots \ldots 62$

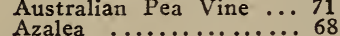

Azara $. . . \ldots \ldots \ldots \ldots \ldots \ldots, 62$

Banana ............62 62

Barberry …......6. 62,68

Begonia Tuberous .....7 76

Berberis $\ldots \ldots \ldots \ldots \ldots 62,68$

Bignonia $\ldots . \ldots \ldots \ldots \ldots \ldots 71$

Birch $\ldots \ldots \ldots \ldots \ldots \ldots .68$

Bleeding Heart $\ldots \ldots \ldots .76$

Blue Marguerite ......78

Blue Spiraea .........6 68

Boston Ivy $\ldots \ldots \ldots \ldots \ldots, 71$

Bottle Brush $\ldots \ldots \ldots \ldots \ldots \%$ \%

Boxwood $\ldots \ldots \ldots \ldots \ldots \ldots 63$

Breath of Heaven $\ldots \ldots \ldots 64$

Bridal Wreath ........7 70

Broom ............6.65

Buddleia $\ldots \ldots \ldots \ldots \ldots \ldots 66.63$

Burning Bush
Bush Honeysuckle .......6 69

Calceolaria $\ldots \ldots \ldots \ldots 79$

California Tree Poppy $\ldots 84$

California Wild Lilac $\ldots 63$

Calla, Yellow .......... 76

Callistemon ..............6 63

Camellia $\ldots \ldots \ldots \ldots \ldots \ldots 63$

Camdytuft, Perennial ..... 82

Candyturt, Perennial ..... ${ }_{79}^{82}$

Canna $\ldots$ terbury Belis $\ldots \ldots \ldots 79$

Carnations $\ldots \ldots \ldots \ldots \ldots 77$

Caryopteris..$\ldots \ldots \ldots \ldots .6 \% 68$

Cassia ...............63 63

Ceanothus .........63, 68

Cedrus $\ldots \ldots \ldots \ldots \ldots \ldots 60$

Cerastium ............. 79

Cestrum ..............6.63 60

Chelone $\ldots . . . \ldots \ldots \ldots . .79$

Cherry, Flowering .......6 68

Cherry, Fruiting ...... 87

Chile Jasmine ......... 72

Choísya $\ldots . . . \ldots \ldots \ldots .63$

Chorizema $\ldots \ldots \ldots \ldots \ldots .63$

Chrysanthemum $\cdots \cdots \cdots 77$

Cistus .............6 63

Clematis $\ldots \ldots \ldots \ldots \ldots \ldots, 71$

Clianthus $. \ldots \ldots \ldots \ldots \ldots \ldots, 71$

Clivia $\ldots \ldots \ldots \ldots \ldots \ldots \ldots 78$

Conifers .............6\%, 61

Convolvulus ...........79 79

Coprosna...$\ldots \ldots \ldots \ldots 63$

Coral Bells ........... 81

Corchorus $\ldots \ldots \ldots \ldots \ldots \ldots .68$

Cornus ................. 68

Cotoneaster $\ldots . . . \ldots .64$

Crab Apple, Flowering . .68

Crab Apple, Fruiting $\ldots 86$

Crape Myrtle ........6 68
Page

Crassula ......... 79

Crataegus (Pyracantha). 67

Crataegus Cordata ......6 68

Cryptomeria $\ldots \ldots \ldots .60$

Currant, Fruiting $\ldots \ldots \ldots$..... 89

Currant, Flowering ......6 68

Dahlia $\ldots . . \ldots \ldots . . .73,74$

Dahlia Imperialis $\ldots \ldots \ldots$. 80

Daphne ................6 64

Delphinium .......... 80

Deutzia ............ 69

Dianthus $\ldots \ldots \ldots \ldots \ldots \ldots .80$

Dielytra $\ldots \ldots \ldots \ldots \ldots \ldots .76$

Diervilla $\ldots \ldots \ldots \ldots \ldots \ldots .70$

Digitalis $\quad \ldots \ldots \ldots \ldots \ldots \ldots \times 80$

Diosma $\ldots \ldots \ldots \ldots \ldots \ldots 6686$

Doronicum $\ldots \ldots \ldots \ldots \ldots .68$

Doronicum $\ldots \ldots \ldots \ldots \ldots .648$

Dragon Palm $\ldots \ldots \ldots \ldots 64$

Echium ........... 80

Eleagnus $\ldots \ldots \ldots \ldots \ldots 64$

Erica..$\ldots \ldots \ldots \ldots \ldots .64$

Erigeron $. \ldots \ldots \ldots \ldots \ldots, \ldots 0$

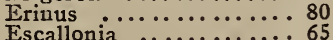

Eucalyptus $\ldots \ldots \ldots \ldots \ldots 665$

Eugenia ............6 65

Euonyinus $\ldots \ldots \ldots \ldots \ldots 665$

Evening Primrose $\ldots \ldots \ldots 8$
Exochorda

Ficus $\quad . \ldots \ldots \ldots \ldots \ldots .72$

Figs $\ldots \ldots \ldots \ldots \ldots \ldots \ldots, 88$

Fir,$\ldots \ldots \ldots \ldots \ldots \ldots \ldots$ 60

Flax, Perennial ....... 82

Foxglove..$\ldots \ldots \ldots \ldots \ldots .6080$

Francoa .............. 80

Fremontia $\ldots \ldots \ldots \ldots \ldots$
Fruit Trees and Smali
Fruits $\ldots \ldots \ldots$ to 89

Fruits
Fuchsia $\ldots \ldots \ldots \ldots \ldots$ to 89

Gaillardia ......... 80

Gazania..$\ldots \ldots \ldots \ldots \ldots 81$

Gazania $\ldots \ldots \ldots \ldots \ldots \ldots \ldots 6 \% 65$

Geranium $\ldots \ldots \ldots \ldots \ldots, 77$

$\underset{\text { Geum }}{\text { Ginko }} \ldots \ldots \ldots \ldots \ldots \ldots \ldots \ldots, 81$

Gladiolus $\ldots \ldots \ldots \ldots \ldots \ldots 75,76$

Gloxinia ............7 76

Golden Beli ..............69 69

Golden Chain ............6 69

Golden Glow $\ldots \ldots \ldots \ldots . .84$

Golden Rod . ............ 85

Gooseberry ......... 89

Grape Fruit $\ldots \ldots \ldots \ldots \ldots$. 88

Grape Fruit $\ldots \ldots \ldots \ldots \ldots \ldots 65$

Grevillea ${ }_{\text {Gypsophila }} \ldots \ldots \ldots \ldots \ldots .6 \%$

Haworthia ......... 81

Hawthorn $\ldots . \ldots \ldots \ldots .69$

Heath $\ldots \ldots \ldots \ldots \ldots \ldots, 64$

Helenium $\ldots \ldots \ldots \ldots \ldots .68$

Helian themum $\ldots . . . . .881$

Helianthus $\ldots . . . \cdots \cdots . .81$

Heliotrope $\ldots . . \ldots \ldots \ldots .81$

Heuchera $\ldots \ldots \ldots \ldots \ldots \ldots$ s1

High Bush Cranberry .... 72

Holly $\ldots \ldots \ldots \ldots \ldots \ldots 65$

Hollyhock $\ldots . . . \ldots \ldots . .81$

Honeysuckle $\ldots \ldots \ldots \ldots \ldots, 72$

Hops $. \ldots \ldots \ldots \ldots \ldots \ldots, 72$

Hydrangea
Hypericum

Iberis $\ldots \ldots \ldots \ldots \ldots .82$

Ice Plant $\ldots \ldots \ldots \ldots \ldots .82$

Iceland Poppy $\ldots \ldots \ldots \ldots .83$

Impatiens $\quad \cdots \cdots \cdots \cdots \cdots \cdots, 66$

Iochroma $\quad \ldots \ldots \ldots \ldots \ldots \ldots, 66$

Irish Moss $\ldots \ldots \ldots \ldots \ldots \ldots 79$

Jasmine

Juniper

72

72
60
Kenilworth Ivy ...... 72

Kenilworth Ivy $\ldots \ldots \ldots \ldots .72$
Kerria $\ldots \ldots \ldots \ldots \ldots 68$

Laburnum. ......... 69

Lantana $\ldots \ldots \ldots \ldots \ldots \ldots 72$

Larkspur $\ldots \ldots \ldots \ldots \ldots \ldots .67$

Laurel ................6 66

Laurustinus $\ldots \ldots \ldots \ldots \ldots 66$

Lavender...$\ldots \ldots \ldots \ldots 82$

Lemon v............ 88

Lemon verbena ....... 69

Leonotis $\ldots \ldots \ldots \ldots \ldots 66$

Leucophyta $\ldots . \ldots \ldots \ldots .82$

Libocedrus $\ldots \ldots \ldots \ldots \ldots 666_{66}$

Ligustrum $\ldots \ldots \ldots \ldots \ldots 66$

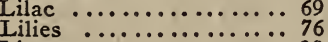

Limes...$\ldots \ldots \ldots \ldots .88$

Linum Lai $\ldots \ldots \ldots \ldots \ldots \ldots .66$

Lion's Tail ..........6.66

Lobelia Cardinalis ...... 82

Locust .............. 69

Loganberry ..........8.89

Lonicera $\ldots \ldots \ldots \ldots \ldots 6,69$

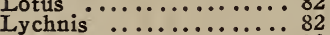

Lychnis $\ldots \ldots \ldots \ldots \ldots \ldots .82$

Magnolia ...........66 66

Mahonia $\ldots \ldots \ldots \ldots \ldots 66$

Maiden Hair Tree ...... 69

Mandevillea $. . . . . \ldots \ldots, 72$

Marguerite $\quad \ldots \ldots \ldots \ldots \ldots .82$

Matilija Poppy $\ldots \ldots \ldots .84$

Mattress Vine...$\ldots \ldots \ldots 72$

Meadow Rue .......... 85

Melaleuca ..........6 66

Mesembryanthemum ...82

Mexican Orange .......66 63

Michaelmas Daisies ..... 79

Mock Orange ........77 70

Moonvine.$\ldots \ldots \ldots \ldots 72$

Mountain $4 . . .6 \%$

Muehlenbeckia $\ldots \ldots \ldots \ldots .88$

Mulberry Ensete $\ldots \ldots \ldots \ldots .62$

Myrtle $\ldots \ldots \ldots \ldots \ldots \ldots 66$

Nandina ........... 66

Nectarine $\quad . \ldots \ldots \ldots \ldots .87$

New Zealand $\dddot{\text { Flax }}$..... 66

Oenothera ........... 83

Oleander...$\ldots \ldots \ldots \ldots 666$

Oleaster .............64 64

Olives .............88

Oranges $\ldots \ldots \ldots \ldots \ldots \ldots, 88$

Oregon Grape $\ldots \ldots \ldots \ldots .66$

Pampas Grass ........ 66

Pansy $\ldots \ldots \ldots \ldots \ldots .68$

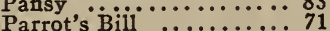

Passion Vine $\ldots \ldots \ldots \ldots \ldots, 72$

Peach, Flowering.... .669

Peach, Fruiting $. . . \cdots \times 87$

Pear $\ldots . . . \ldots \ldots \ldots . .87$

Pearl Bush ..........6 69

Pentstemon ..........83

Pepper $\ldots \ldots \ldots \ldots \ldots \ldots 67$

Pernettya ..............6 67

Persimmon $\ldots \ldots \ldots \ldots$. 88

Phenomenal Berry ....... 89

Philadelphus .......... 70

Phlox ............. 83

Phormium ............6 66

Photinia ..............67 67

Physostegia $\ldots \ldots \ldots \ldots$. 83

Picea...$\ldots \ldots \ldots \ldots \ldots 61$

Pimelea ...............6.67 61

Pine....$\ldots \ldots \ldots \ldots 61$

Pittosporum.$\ldots \ldots \ldots .67$

Pinks, Border $\ldots \ldots \ldots \ldots .80$

Pleroma $\ldots \ldots \ldots \ldots \ldots .67$

Plum, Fruiting $\ldots \ldots \ldots .88$

Plum, Purple Leaved ....7 70

Plumbago, ….... $7 \dot{2}, 83$

Polygala
Polygonum
............... 72

Page

Pomegranate, Flowering - 70

Pomegranate, Fruiting . .88

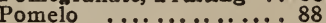

Poplar

Potentilla

Primrose

Privet

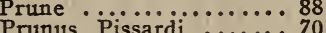

Prunus $\begin{aligned} & \text { Pissardi } \ldots \ldots \ldots .70 \\ & \text { Prunus Triloba } \ldots \ldots \ldots .70\end{aligned}$

Pyracantha $\ldots \ldots \ldots \ldots \ldots 67$

Pyrethrum.$\ldots \ldots \ldots \ldots .68$

Quince, Flowering ....7 70

Quince, Fruiting ....... 88

Raphiolepis .........67 67

Raspberry $\ldots \ldots \ldots \ldots .89$

Red Hot Poker $\ldots \ldots \ldots \ldots 85$

Redwood ${ }_{\text {Rehmannia }} \ldots \ldots \ldots \ldots \ldots .61$

Rehmannia $\ldots \ldots \ldots \ldots \ldots$. 84

Rhododendron $\ldots \ldots \ldots \ldots 67$

Rock Rose

Romneya

Rosemary

mary $\ldots . . . \cdots \cdots \cdots .848$

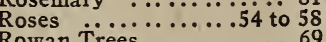

Rudbeckia $. . . \ldots \ldots \ldots . .684$

Salvia ............. 84

Saponaria $\ldots \ldots \ldots \ldots \ldots .64$

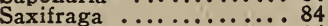

Scabiosa $\ldots \ldots \ldots \ldots \ldots \ldots .64$

Sea Pink $\ldots \ldots \ldots \ldots \ldots \ldots 78$

Sempervivum ........... 85

Sequoia $\ldots . . \ldots \ldots \ldots \ldots 61$

Shasta Daisy ............84

Snowball .............. 70

Snowberry $\ldots \ldots \ldots \ldots \ldots 70$

Solidago $\ldots . \cdots \cdots \cdots \cdots \times \frac{85}{72}$

Spiraea $\ldots \ldots \ldots \ldots \ldots \ldots, 70,85$

Spruce $\ldots . . \ldots \ldots \ldots \ldots \ldots, 61$

Statice ............ 85

Stokesia $\ldots \ldots \ldots \ldots \ldots \ldots \ldots$
Strawberry $\ldots \ldots \ldots \ldots$

Strawberry Tree ........6 62

Strawberry, Ornamental. 85

Streptosolon ......... 85

Stone-crop Perennial ... 81

Sun Rose $\ldots \ldots \ldots \ldots .81$

Sycamore

Symphoricarpos ........7 70

Syringa...$\ldots \ldots \ldots \ldots .69$

Tamarix ........... 70

Taxus $\ldots \ldots \ldots \ldots \ldots \ldots 61$

Thalictrum $\ldots . . \ldots \ldots \ldots . .85$

Thorn...$\ldots \ldots \ldots \ldots \ldots .69$

Thuya $\ldots \ldots \ldots \ldots \ldots \ldots .61$

Thyme $\ldots \ldots \ldots \ldots \ldots \ldots \ldots .685$ 


\section{SUPERB COLLECTION OF}

\section{Pkts. Spencer Sweet Peas $\$ 1.00$}

AUSTIN FREDERICK IMPROVED-Giant lavender.

CRIMSON KING-Rich deep crimson.

ELFRIDA PEARSON-Giant shell-pink.

GEORGE SHAWYER-Giant salmon-rose.

HAWLMARK PINK-Rich rose-pink flushed with salmon.

HERCULES-Bright pink.

IILUMINATOR-Rose suffused salmon.
-KING WHITE-Pure white. MISS CALIFORNIA-Salmon and cream-pink. MRS. TOM JONES-Bright delphinium-blue. ROYAL PURPLE-Best purple. ROYAL SCOT-Brilliant scarlet, sunproof. WARRIOR-Dark maroon. WEMBLEY-Lavender suffused blue. YOUTH-Pure white margined with pink.

\section{HALLAWELL'S Prize Strain Pansies}

Packet of 500 Seeds - $\quad$ - 50 Cents

\section{Special Gladioli Collection}

ANNA EBERIUS-Dark velvety purple.

CARMEN SYLVA-Pure white, slight-violet markings deep in throat.

CRIMSON GLOW-Brilliant crimson.

DIANA-Rich blood-red.

EARIY SUNRISE-Red with salmon-yellow throat.

E. J. SHAYLOR-Deep rose-pink.

FAY IANPHIER - Coral with cerise blending.

GOLDEN MEASURE-Deep yellow.

HAIIEY-Salmon-pink, blotched yellow.

HERADA-Pure mauve.

IDA VAN-Flaming orange-red.

IE MARECHAL FOCH-Soft pink.

LOUISE-Lilac.
MIRS. F. C. PETERS-Rose-lilac with crimson blotch. MRS. FRANK PENDIETON-Salmon-pink with a conspicuous blood red blotch in the throat.

MRS. WATT-Deep cherry-red.

ORANGE GLORY-Rich orange.

PANAMA-This grand variety resembles America, but is much deeper pink.

PEACE - White, interior of petals feathered pale lilac.

PINK WONDER-La France pink.

PRINCE OF WATES-Light salmon.

ROSE ASH-Old rose.

ROSELLA-Light rose with white blotch.

SCHWABEN-Clear canary yellow.

VIRGINIA-Glowing scarlet. 